Fossil

Energy

Phogram

\title{
Survey of Industrial Coal Conversion Equipment Capabilities: Rotating Components
}

\author{
W. R. Williams \\ J.R. Horton \\ W. F. Boudreau \\ M. Siman-Tov
}




\section{DISCLAIMER}

This report was prepared as an account of work sponsored by an agency of the United States Government. Neither the United States Government nor any agency Thereof, nor any of their employees, makes any warranty, express or implied, or assumes any legal liability or responsibility for the accuracy, completeness, or usefulness of any information, apparatus, product, or process disclosed, or represents that its use would not infringe privately owned rights. Reference herein to any specific commercial product, process, or service by trade name, trademark, manufacturer, or otherwise does not necessarily constitute or imply its endorsement, recommendation, or favoring by the United States Government or any agency thereof. The views and opinions of authors expressed herein do not necessarily state or reflect those of the United States Government or any agency thereof. 


\section{DISCLAIMER}

Portions of this document may be illegible in electronic image products. Images are produced from the best available original document. 


\section{Printed in the United States of America. Available from National Technical Information Service \\ U.S. Department of Commerce \\ 5285 Port Royal Road, Springfield, Virginia 22161 \\ Price: Printed Copy $\$ 3.00$

$$
9.52
$$

This report was prepared as an account of work sponsored by an agency of the United States Government. Neither the United States Government nor any agency thereof, nor any of their employees, contractors, subcontractors, or their employees, makes any warranty, express or implied, nor assumes any legal liability or responsibility for any third party's use or the results of such use of any information, apparatus, product or process disclosed in this report, nor represents that its use by such third party would not infringe privately owned rights. 
Contract No.' W-7405-eng-26

ORNL Engineering

SURVEY OF INDUSTRIAL COAL CONVERSION EQUIPMENT CAPABILITIES: ROTATING COMPONENTS

W. R. Williams

J. R. Horton

W. F. Boudreau

M. Siman-Tov

OAK RIDGE NATIONAL LABORATORY

Oak Ridge, Tennessee 37830

operated by

UNION CARBIDE CORPORATION

Nuclear Division

for the

DEPARTMENT UF ENERGY 
THIS PAGE

WAS INTENTIONALLY

LEFT BLANK 
CONTENTS

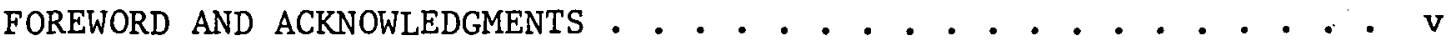
ABSTRACT .......................... 1

1. INTRODUCTION ...................... 1

2. SUMMARY ..................... 5

3. DATA COLlection . . . . . . . . . . . . . . . 7

3.1 Bas1s for Equipment Specifications . . . . . . . . . 7

3.2 Equipment Characteristics . . . . . . . . . . . . 9

3.3 Equipment Grouping and Identification . . . . . . . . 15

3.4 Questionnaires . . . . . . . . . . . . . . . 20

3.5 Manufacturers . . . . . . . . . . . . 24

4. SURVEY RESULTS . . . . . . . . . . . . . . . 27

4.1 Pumps .................... 27

4.2 Compressors ................. . . 34

4.3 Hydraulic Turbines................. 38

4.4 Gas Expanders ... . . . . . . . . . . . . 41

5. ANALYSIS AND DISCUSSION . . . . . . . . . . . . 47

5.1 Pumps . . . . . . . . . . . . . . . . . . 47

5.2 Compressors .. . . . . . . . . . . . . 65

5.3 Hydraulic Turbines . . . . . . . . . . . . . 72

5.4 Gas Expanders ................. 77

6. CONCLUSIONS AND RECOMMENDATIONS ............... 81

6.1 Availability .................... 81

6.2 Research and Development Needs........... . 85

6.3 Additional Areas of Study ............ . 88

REFERENCES ............................991

Appendix A. PROCESSES FORMING A BASIS FOR EQUIPMENT

SPECIFICATIONS . . . . . . . . . . . . . A-1

Appendix B. QUESTIONNAIRES . . . . . . . . . . . . . B-I

Appendix C. LOCATION OF MODELS FOR EQUIPMENT SPECIFICATIONS . . . C-1

Appendix D. MANUFACTURERS RESPONDING TO ROTATING

EQUIPMENT QUESTIONNAIRES . . . . . . . . . . . D-1

Appendix E. RESPONSES FROM MANUFACTURERS TO QUESTIONS ON

AVAILABILITY AND CAPACITY . . . . . . . . . . . E-1 
THIS PAGE

WAS INTENTIONALLY

LEFT BLANK 
FOREWORD AND ACKNOWLEDGMENTS

This is one of four reports describing surveys of industrial coal conversion equipment capabilities which were conducted for and supported by the Equipment Branch (James Powe11, Branch Chief, and T.'K. Lau, Project Manager) of the Fossil Energy Major Facilities Project Management Division (MFPM) * of the Energy Research and Development Administration (ERDA).* This report describes the results of the survey relating to rotating components (pumps, compressors, gas expanders, and hydraulic turbines); other reports in this series are:

- W. A. Bush and E. C. Slade, Survey of Industrial Coal Conversion Equipment Capabilities: Valves, ORNL/TM-6071, Oak Ridge National Laboratory (1978).

- J. P. Meyer and M. S. Edwards, Survey of Industrial Coal Conversion Equipment Capabilities: High Temperature, High Pressure Gas Purification, ORNL/TM-6072, Oak Ridge National Laboratory (1978).

- W. R. Gambill and W. R. Reed, Survey of Industrial Coal Conversion Equipment Capabilities: Heat Recovery and Utilization, 0RNL/TM-6073, Oak Ridge Nationa1 Laboratory (19.78).

The authors of this report appreciate the rotating-equipmentindustry personnel who have given their time and effort to reply to our questionnaires and have met with us to discuss availability and problems of equipment required by the coal conversion industry. Without their cooperation, this report would not have been possible.

We also express our appreciation to the architect-engineers and users of rotating equipment who set aside time to meet with us. Our thanks also go to the many people in the Union Carbide Nuclear Division who have provided assistance during this study.

*Effective October 1, 1977, ERDA became part of the Department of Energy (DOE); MFPM has since become part of the Division of Coal Conversion of DOE. 
SURVEY OF INDUSTRIAL COAL CONVERSION EQUIPMENT CAPABILITIES: ROTATING COMPONENTS

W. R. Williams

J. R. Horton

W. F. Boudreau

M. Siman-Tov

\begin{abstract}
A study was undertaken at the request of the Major Facilities Project Management Division of the Energy Research and Development Administration, Fossil Energy Division, to determine the capabilities of U.S. industry to supply the rotating equipment needed for future coal conversion facilities. Furthermore, problem areas were to be identifled and research and development needs determined for producing the required equipment of advanced design. The equipment of interest includes pumps, compressors, hydraulic turbines, and gas expanders.

It has been concluded that equipment for essentially all clean-stream applications likely to be encountered in coal conversion facilities is generally avallable except high-pressure oxygen compressors. These oxygen compressors as well as slurry pumps need to be developed or significantly upgraded. Also, fans and blower for dirty-gas streams need developmental work, as do expanders for high-temperature service. Hydraulic turbines, which were not specifled but which might be used for slurry applications in furture coal conversion plants, are not available.
\end{abstract}

\title{
1. INTRODUCTION
}

W1th the increased realization of shortages of oil and natural gas and with increased U.S. dependence on foreign ofl, serious attention is being given to the commerclalization of advanced processes for the conversion of coal to clean liquids and gases. A number of these processes have been under development for many years; many additional processes are currently being studied. Of these processes, some are in the pilot-plant stage, others are ready for scale-up to demonstration-size units, and still others are ready for commercialization. There are many existing conceptual designs for coal conversion facllities based on such processes. The question now raised is whether or not the cquipment specified in such 
designs is indeed readily available from U.S. industry. If not, the.. question becomes one of determining how much lead time is required to develop such equipment.

The potential to have demonstration and commercial coal conversion facilities in timely production depends in part on the availability of the necessary equipment and in part on the time required for construction of the facilities. The Major Facilities Project Management Division (MFPM) of the Energy Research and Development Administration, Fossil Energy Division, has bèn charged with the rask of overseeling lhe cuill= mercialization of coal conversion in the United States. This study, which supports the efforts of MFPM, was initiated with a twofold objective:

1. determination of present capabilities of U.S. industry to supply equipment needed for future demonstration and commercial coal conversion facilities and

2. identification of problem areas as well as determination of research and development needs for producing equipment of advanced design, including lead time requirements.

The total project includes all types of equipment found in a coal conversion plant; however, only four categories have been studied this year: rotating components, valves, hot-gas clean-up devices, and heat-recovery equipment. This report addresses only the first category, rotating components, which includes pumps, compressors, hydraulic turbines, and gas expanders. Three additional reports covering the other categories are being issued concurrently with this report; citations appear in the Foreword and Acknowledgments.

This study consists of three principal phases: (1) the determination of rotating equipment requirements based on existing conceptual designs, (2) a survey of industry to determine availability of equipment, and (3) an analysis of problem areas and possible solutions. Each of these phases will be discussed in detail in subsequent sections of this report. Section 3 considers the methods employed in pursuing these principal phases and gives the rationale for their use, Sect. 4 presents the data obtained during this study, and sect. 5 presents the findings and conclusions drawn. Recommendations for research and development are 
summarized in Sect. 6, with considerations of their relative importance." This'iast section also includes a summary of the availability of rotating equipment and presents unanswered questions raised by this study'as well as additional topics needing further study. Section 2 presents briëly the findings of this study. 
THIS PAGE

WAS INTENTIONALLY

LEFT BLANK 


\section{SUMMARY}

The first step toward meeting the objectives in Sect. 1 was selection of seven coal conversion conceptual design reports as a basis for equipment specifications. These reports cover both liquefaction and gasification processes. Information on these processes is included in Appendix $A$ and is summarized in Table 1, Sect. 3.

Equipment specification lists in the design reports were screened for pumps, compressors, hydraulic turbines, and gas expanders operating under the more severe conditions. The operating parameters collected were compared and consolidated to yield the final equipment lists, which appear as a part of the questionnaires in Appendix B. Additional information on the models for the specified equipment may be obtained from Appendixes C and A. Table 2, Sect. 3, gives limits of operating parameters for each type of equipment.

The primary data source on equipment availability and problems was the rotating equipment industry. Information was obtained through a series of four questionnaires, each dealing with one of the major rotating equipment categories. A total of 222 questionnaires was sent to industry, and 57 responses were returned; responses were received from almost all of the first-line equipment vendors. Additional data were obtained during visits to architect-engineers and users of rotating equipment as well as in follow-up meetings with vendors, either at their facilities or in Oak Ridge. Industrial coverage is summarized in Tables 5 and 6, Sect. 3, and in Appendix D. The data received are presented in Sect. 4 and Appendix E without comment.

In Sect. 5, the data are analyzed and discussed with respect to availability, problem areas and proposed solutions, and research and development needs. In Subsect. 6.1, conclusions about equipment availability are reviewed, with present limitations on equipment being summarized in Table 17. Recommendations concerning research and development needs to develop unavailable equipment or to upgrade existing equipment to meet the demands of coal conversion appear in Subsect. 6.2. Finally, additional areas needing study but for which time was not available are reviewed in Subsect. 6.3 . 
It is concluded that equipment is generally available for essentially all clean-stream applications likely to be encountered in coal conversion facilities with the exception of oxygen compressors for pressures greater than 600 psia. Equipment critical to the success of the coal conversion industry which needs to be developed or significantly upgraded includes not only high-pressure oxygen compressors but also slurry pumps and low-pressure fans and blowers capable of handling dirty streams. The development of expanders is critical to the practicability of several processes. Hydraulic turbines may be desirable for power recovery from slurry streams; however, their unavailability will not seriously affect any processes. 


\section{DATA COLLECTION}

The collection of accurate and pertinent data is a prerequisite to meeting the objectives of this study reliably. Because this survey is on equipment availability, a basis was first established for the specification of equipment-operating characteristics; these characteristics were then determined. Next, questionnaires were composed to establish the present and anticipated capabilities of industry and the problems that must be overcome. Last, the equipment specifications and questionnaires were sent to manufacturers of the equipment considered in this survey. Each of these phases is discussed in the following subsections.

\subsection{Basis for Equipment Specifications}

Many conceptual designs of demonstration and commerclal facilities for coal liquefaction and gasification have been produced by several organizations such as architect engineers, national and other government laboratories, and consortiums. Several designs frequently exist for each process. To select the designs that would serve as a specification basis for equipment requirements, discussions were held with several staff members involved with the coal programs of the Oak Ridge National Laboratory. As a result of these discussions, seven designs were chosen, based on the following processes, as a basis for this study: BI-GAS, Coalcon, Fischer-Tropsch, Hydrocarbonization, HYGAS, Lurgi, and Synthoil. The range of operating characteristics for equipment in these processes is believed to include the most severe conditions likely to be encountered in coal conversion; however, there may possibly be more severe applications in processes not considered. * A summary of the conceptual designs selected is given in Table 1 .

A more complete description of each process as to the source of information, coal feed requirements, and major products appears as

\footnotetext{
* During discussions with architect engineers and manufacturers, only
} a few slightly more severe requirements were encountered. 
Table 1. Conceptual designs forming a basis for equipment requirements

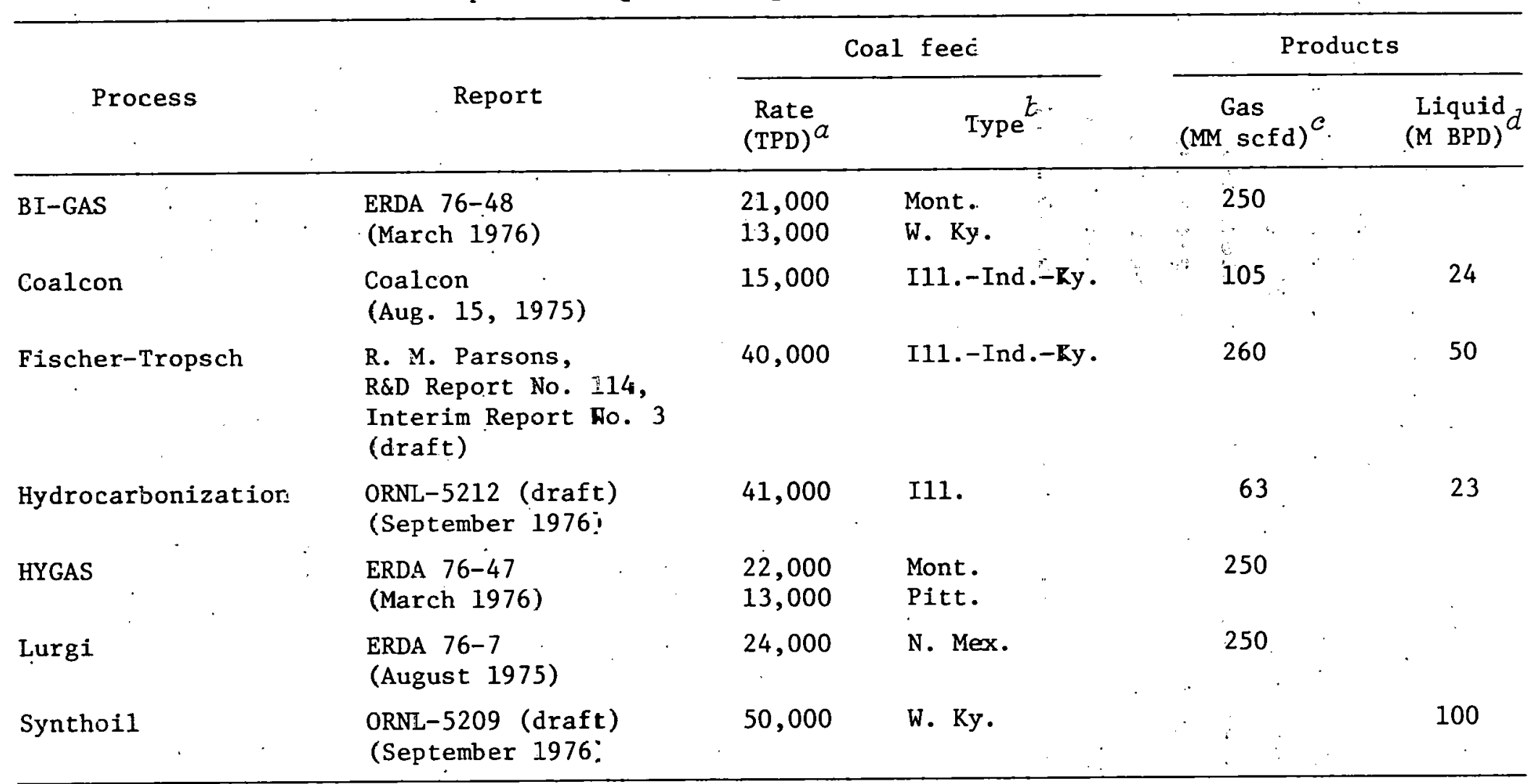

$a_{\text {TPD }}=$ tons per day.

${ }^{b}$ Coal Type is identified by standard state abbrevlations except. $W .:$ Ky. = western Kentucky, Pitt. = Pittsburgh.

${ }^{C}$ MM scfd $=$ millions of standard cubic feet per day (standand conditions are $60^{\circ} \mathrm{F}$ and 14.7 psia).

$d_{M B P D}=$ thousarids of barrels per day. 
Appendix A. A simplified block flow diagram for each process and a 11st of equipment items, that serve as models for the specification of equipment requirements are also included in Appendix A.

Three additional conceptual designs, based on the $\mathrm{CO}_{2}$ Acceptor, HYGAS, and HYGAS (Steam-Iron) processes, were reviewed to supplement Information on hydraulic turbines and gas expanders. Information sources for these processes are also included in Appendix A.

The conceptual designs considered include pressures to more than 1000 pounds per square Inch absolute (psia). for gasification processes and more than 4000 psia for Iiquefaction. Except for hot-gas expanders; the maximum temperature encountered by the rotating equipment is approximately $750^{\circ} \mathrm{F}$; expander inlet temperatures range up to about $1750^{\circ} \mathrm{F}$. Slurry concentrations are as great as 60 wt $\%$.

\subsection{Equipment Charactertstics}

Each conceptual design examined in this study Included equipment specifications lists, which were screened for equipment operating under the more severe conditions. Additional information on these equipment 1tems was obtalned from the flow sheets for each process. Operating conditions thus collected were compared and consolidated to yield Ifsts of equipment appearing as part of the questionnalres sent to industry. These equipment lists may be found in Appendix B.

Each of the operating parameters considered is discussed below to Identify limitations of the data and assumptions that were made. The discussion follows the order in which these parameters appear in the equipment 11sts.

Flow Rate is the most basic parameter required for sizing a plece of rotating equipment. For pumps and hydraulic turbines, flow rates were specifled as gallons per minute (gPm); flow rates for compressors and gas expanders were spectfied as actual cublc feet per minute (acfm) at inlet conditions ( $1 . e .$, inlet temperature and pressure).

Some equipment has been specified with flow rates in excess of those required by the conceptual designs that form a basis for this study. In some Instances, several items of equipment appear in the equipment lists 
differing only in flow rate; in these cases, the larger capacities represent the replacement of several smaller units by a larger unit. When there is demonstrated equipment reliability, these larger units may be desired. At other times, however, the data as a whole warranted dropping some required flow rates in favor of larger rates because of similar operating conditions for different flows in several conceptual designs.

Solids handling in rotating equipment requires specific attention. Solids Content was therefore identified apart from the stream composition. For slurries, the solide content was presented as a weight perrent of the total stream flow and was included under both this parameter and under "Stream Composition" because the solids could represent a significant portion of the volume flow through the pump or hydraulic turbine. Solids found in slurries were ash, char, and coal, either individually or in combination; there were no levels of solids loading in which any one solid predominated in the slurry stream. Therefore, the particular solid was not specified in the final equipment lists. The solids content of gas streams was specified as grains per actual cublc foot of gas at inlet conditions.

For compressors, coal dust was found to be present in several highflow, low-pressure ratio blowers. Expanders were requlred tu halidle several different types of particulates; some information on these particulates was also supplied in the expander equipment 1 ist.

Solids content with respect to both the level of loading and the nature of the particles has a significant effect on materials selection and the life of equipment because of resulting erosion.

The density of the fluid being pressurized, whether it is a liquid or a gas, is another parameter that will significantly affect the design of rotating equipment. Specific Gravity with respect to water can be used as a relative measure of density for liquids because almost all pumps that are performance tested in manufacturers' facilities are tested on water. Molecular Weight serves a similar purpose and is also better suited for gases because they are compressible. 
Inlet Temperature can have a significant effect on construction materials and the overall design of both liquid- and gas-handling equipment.: With respect to gases that are compresslble fluids, inlet temperature will affect the density of the gas and hence the size of the equipment as well as the amount of intercooling required during compression. "For;, high temperatures, case cooling may be required; blade cooling may also. be required in compressors and, particularly, in expanders. Temperatures are in degrees Fahrenheit $\left({ }^{\circ} \mathrm{F}\right)$.

Inlet Pressure can influence significantly. the design and performance. of equipment. This fact is particularly true of pumps in which the net positive suction head (NPSH) required must be no greater than the NPSH available ${ }^{*}$ from the process; otherwise, cavitation can occur, leading to. severe pump damage. Required NPSH can be reduced by increasing the : diameter of the impeller eye; alternatively, NPSH required can be met by using booster pumps specifically designed for low available NPSH: Information available in the conceptual design reports was insufficient to evaluate NPSH available for all of the various applicationsi and was therefore not included.

Based on volume, inlet flow rate in compressors is approximately inversely proportional to inlet pressure for a given mass flow rate; thus, when all other parameters are equal, a lower inlet pressure requires a larger compressor. In the case of hydraulic turbines and gas expanders, the inlet pressure will affect their design with respect to pressure containment and materials of construction. Both inlet and outlet pressures are specified as pounds per square inch absolute (psia).

Outlet Pressure affects the design of pumps and compressors with respect to pressure containment and materials of construction. Back pressure on turbines and expanders is also important to design; in particular, back pressure on turbines must be sufficient to prevent cavitation; expander-outlet pressure will do much to determine the size of the unit.

\footnotetext{
*NPSH available is equal to the difference between the inlet pressure and the vapor pressure of the liquid at inlet tomperature.
} 
Pressure Head and Pressure Ratio, which are derived quantities, are important parameters in the design of rotating equipment. The magnitude of these quantities is related to the total number of stages required in an equipment unit, though other factors are also involved.

Pressure head is the change in pressure from the inlet to the outlet of a pump and may be expressed as

$$
\Delta P=P_{0}-P_{i}
$$

where

$$
\begin{aligned}
& \Delta P=\text { pressure head, psi, } \\
& P_{0}=\text { outlet pressure, psia, } \\
& P_{i}=\text { inlet pressure psia. }
\end{aligned}
$$

In the case of hydraulic turbines, this equation also holds except that $\Delta P$ is negarive.

For compressible gases, pressure ratio serves a purpose analogous to pressure head for incompressible liquids and is defined as

$$
r=P_{o} / P_{i}
$$

where $r$ is the pressure ratio. This ratio can be used to clialacleitze both compressors and expanders; however, the reciprocals of the pressure ratio $\left(r^{-1}=\mu_{i} / F_{0}\right)$ were used fur Llit expanders.

Positive heads or ratios grcater than 1 imply that power is required. Power is available for recovery when the head is negative or the pressure ratio is less than 1 .

Ideal Horsepower was determined for each item of equipment as a function of inlet and outlet conditions, using the general relationship

$$
W=\int_{P_{i}}^{P_{0}} V \mathrm{~d} P,
$$


where

$W=$ work input (positive) or output (negative), hp,

$V=$ volume flow rate,

$P=$ pressure.

Inefficienciès resulting from mechanical or fluid considerations are not considered.

For incompressible (constant volume) liquids, Eq. (3.3) integrates to

$W=V \Delta P$,

or

$W=\frac{Q \Delta P}{1714}$

where

$Q=$ flow rate, gpm.

For compressible gases, the following additional assumptions were made: (1) the ideal gas law applies in all cases, and (2) all compressions or expansions are isothermal. The ideal gas law states that

$$
P V=n R T,
$$

where

$$
\begin{aligned}
& n=\text { molar flow rate } \\
& R=\text { ideal gas constant } \\
& T=\text { absolute temperature. }
\end{aligned}
$$

Inserting this equation into Eq. (3.3) and integrating yields, for isothermal compression or expansion,

$$
W=n R T \ln \left(P_{0} / P_{i}\right)
$$


or

$$
W=0.00436 Q_{i} P_{i} \ln \left(P_{o} / P_{i}\right)
$$

where

$$
Q_{i}=\text { inlet flow rate, acfm. }
$$

For compressors, the horsepower calculated by Eq. (3.8) is the minimum required for the desired compression, assuming (as previously stated) that there are no inefficiencies, that the ideal gas law holds, and that the compression is isothermal. Under the same assumptions, Eq. (3.8) yields the maximum horsepower recoverable by an expander.

In practical compressors, the temperature of the gas increases in either an adiabatic or polytropic manner; in expanders, temperature decreases in a similar manner. Single-stage uncooled compressors require the maximum power input for compression. If the compression process is divided into a number of stages, each consisting of a partial compression followed by intercooling to the initial temperature, then the horsepower requirement decreases as the number of stages increases and, for a very large number of stages, approaches the isothermal horsepower given by Eq. (3.8). Conversely, nonisothermal expansion leads to a decrease in recoverable power; multistaging of an expander with reheating to the initial temperature between stages causes recovered horsepower to approach the maximum calculated from Eq. (3.8).

Because all horsepower values are ideal and exclude all inefficiencies, the values tabulated in the equipment lists in Appendix $B$ are less than those required to drive pumps and compressors and are greater than those recovered by turbines and expanders.

The Stream Composition of liquid streams is reported in weight percentages. The composition includes not only the liquid portion of those streams but also solids and/or dissolved gases when they are present. Because the density of solids does not differ greatly from that of the liquid medium, the solids can represent a significant portion of the total volume passing through the pump or hydraulic turbine. In gas streams, however, solids form an infinitesimal part of the total volume flow and 
are therefore not represented as part of the total stream. Gas composition is expressed in mole percentages. The stream composition plays an important part in equipment design materials selection. The effect of solids was discussed earlier. Corrosive streams may require special materials, and toxic or flammable streams will require special equipment designs.

In addition to the preceding characteristics, information was also supplied on hydraulic turbines and gas expanders. For the hydraulic turbines used to drive pumps, both the flow rates through the pumps and the ideal horsepower required by thuse pumps were provided. Some information on particulate characteristics was supplied in the expander equipment lists.

The most severe operating condition encountered in each characteristic by each type of equipment is tabulated in Table 2. No one single piece of equipment is expected to operate under the combination of all of these severe conditions; individual items of equipment, however, may. involve one or more of these limits in a given application.

\subsection{Equipment Grouping and Identification}

Once the initial lists of equipment characteristics were compiled, it was advantageous to eliminate excess equipment having similar operating conditions. It was found that the pump and compressor lists could be most easily reduced by first dividing them according to outlet pressure and either pressure head (for pumps) or pressure ratio (for compressors) and then comparing them with other operating parameters in these groupings. This categorization was retained for identifying equipment throughout the project and in this report. These categories are illustrated in Figs. 1 and 2 and are more fully explained in Table 3. Because of the smaller numbers of hydraulic turbines and gas expanders, these lists were not subdivided.

Individuals who wish to study the various equipment applications in more detail should find Appendix $C$ useful. This appendix is a cross reference between the applications appearing in Appendix $B$ and the models on which they are based. Appendix $C$ includes both the flow rate of the model and the process in which it is found. One may find the reference report and the unit operation in which the model occurs in Appendix $A$. 
Table 2. Limits of operaring parameters encountered by rotating equipment

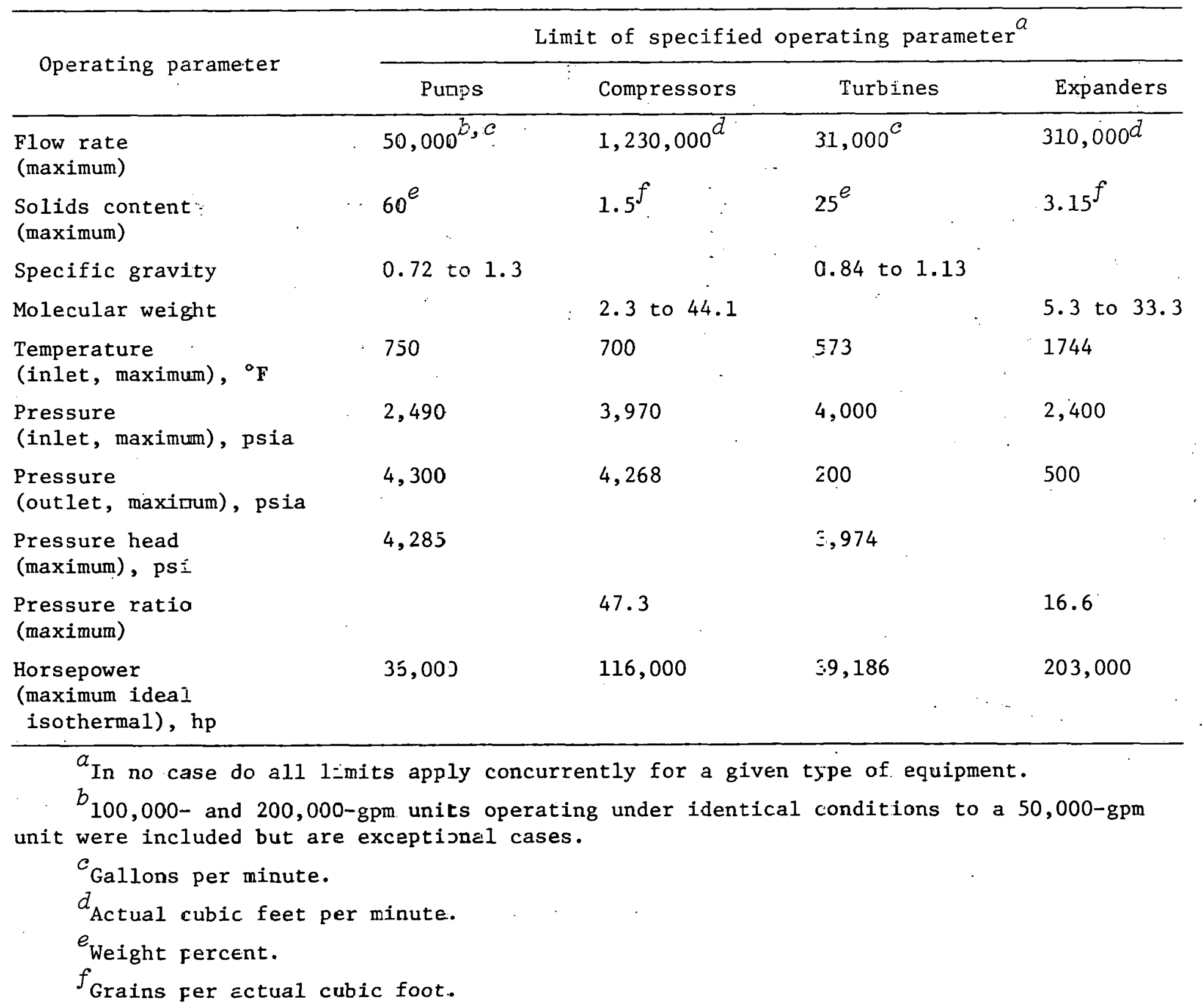




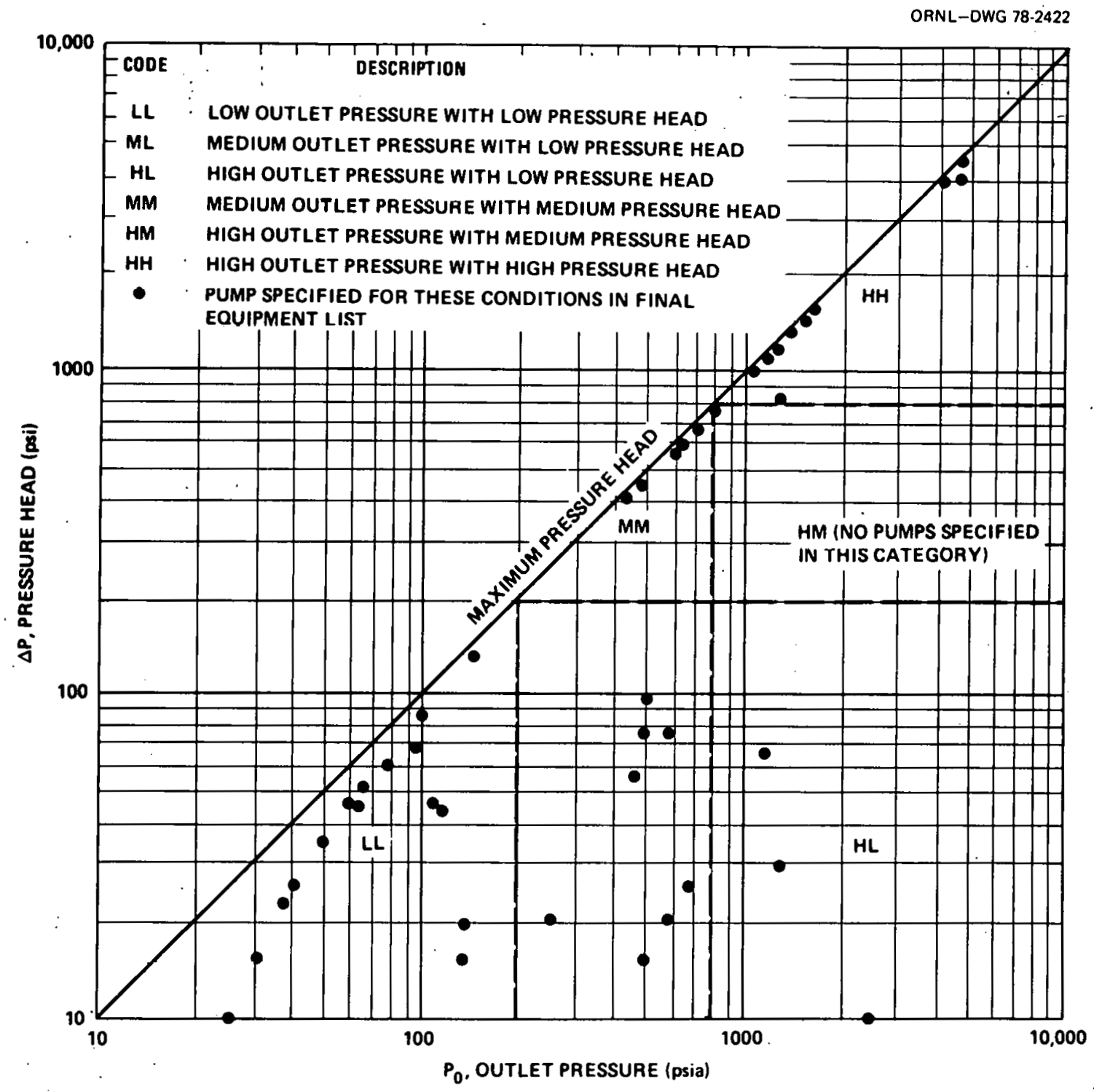

Fig. 1. Categories of pumps showing locations of pumps specified In the final pump list. 


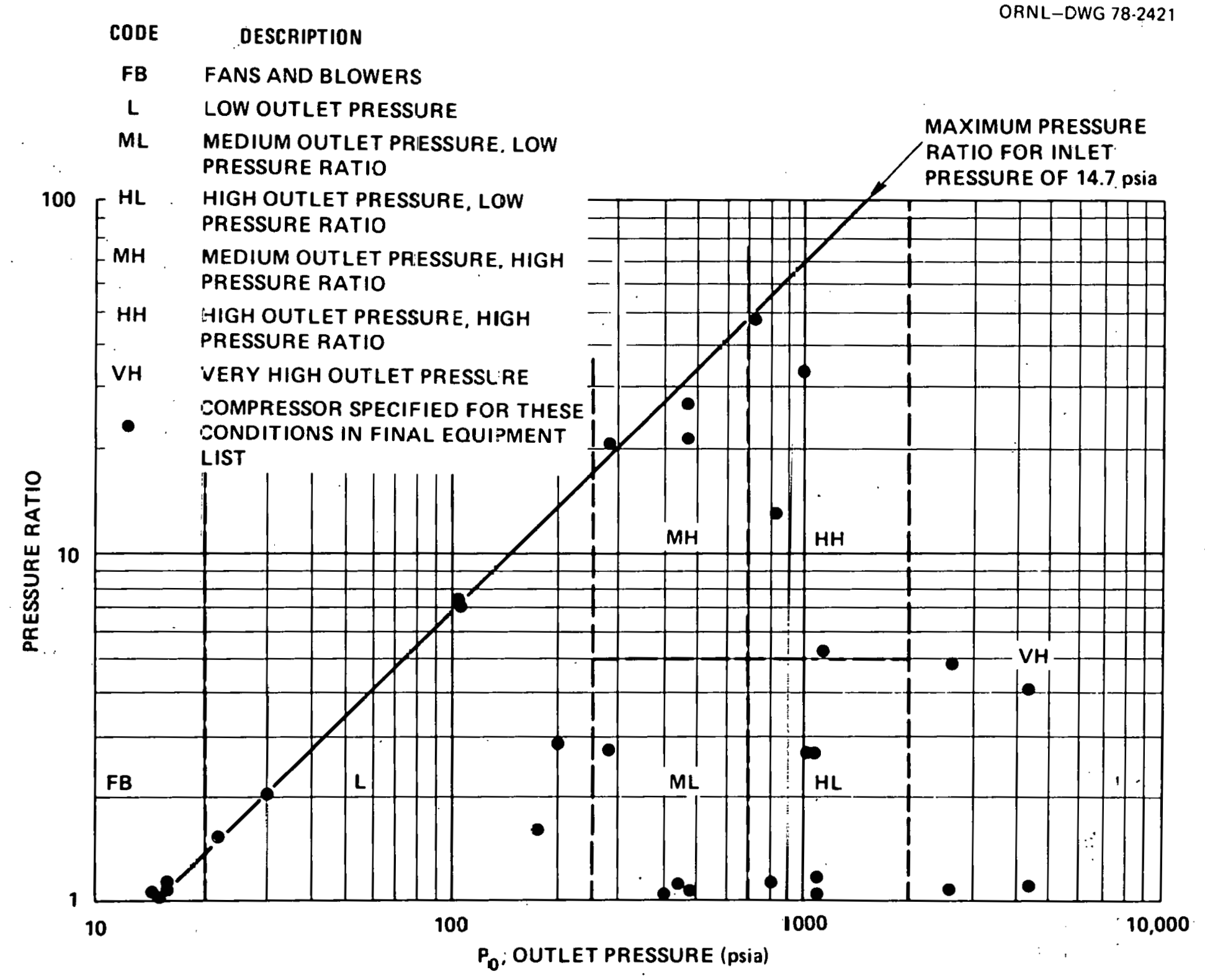

Fig. 2. Categories of compressors showing locatiors of compressors specified in the final compressor list. 
Table 3. Equipment identification key

(Equipment in this report is identified by one or two letters followed by a hyphen and a number. Letter meanings are given below. See Appendix B for complete identifier and corresponding equipment operating conditions.)

\begin{tabular}{|c|c|c|}
\hline Category & Letter $(s)$ & Meaning \\
\hline \multirow[t]{6}{*}{ Pumps } & LL & $\begin{array}{l}\text { Low outlet pressure ( } 0 \text { to } 200 \text { psia) } \\
\text { with low-pressure head (0 to } 200 \text { psi) }\end{array}$ \\
\hline & ML & $\begin{array}{l}\text { Medium outlet pressure (200 to } 800 \text { psia) } \\
\text { with low-pressure head }\end{array}$ \\
\hline & HL & $\begin{array}{l}\text { High outlet pressure }(800+\text { psia }) \text { with } \\
\text { low-pressure head }\end{array}$ \\
\hline & MM & $\begin{array}{l}\text { Medium outlet pressure with medium- } \\
\text { pressure head ( } 200 \text { to } 800 \text { psi) }\end{array}$ \\
\hline & $\mathrm{HM}$ & $\begin{array}{l}\text { High outlet pressure with medium- } \\
\text { pressure head }\end{array}$ \\
\hline & $\mathrm{HH}$ & $\begin{array}{l}\text { High outlet pressure with high- } \\
\text { pressure head }(800+\text { psi) }\end{array}$ \\
\hline \multirow[t]{7}{*}{ Compressors } & FB & $\begin{array}{l}\text { Fans and blowers (approximately } \\
\text { atmospheric operating pressure with } \\
\text { pressure ratio less than } 1.1 \text { ) }\end{array}$ \\
\hline & L & Low outlet pressure ( 20 to 250 psia) \\
\hline & ML & $\begin{array}{l}\text { Medium outlet pressure ( } 250 \text { to } 700 \mathrm{psia}) \\
\text { with low-pressure ratio }(1.0 \text { to } 5.0)\end{array}$ \\
\hline & HL & $\begin{array}{l}\text { High outlet pressure ( } 700 \text { to } 1500 \text { psia) } \\
\text { with low-pressure ratio }\end{array}$ \\
\hline & MH & $\begin{array}{l}\text { Medium outlet pressure with high- } \\
\text { pressure ratio }(5.0+)\end{array}$ \\
\hline & $\mathrm{HH}$ & $\begin{array}{l}\text { High outlet pressure with high-pressure } \\
\text { ratio }\end{array}$ \\
\hline & $\mathrm{VH}$ & Very high outlet pressure (1500+ psia) \\
\hline Hydraulic turbines & $\mathrm{T}$ & \\
\hline Gas expanders & $\mathrm{E}$ & \\
\hline
\end{tabular}




\subsection{Questionnaires}

The method of collecting data is extremely important in the assessment of equipment availability and the identification of problem areas. Four questionnaires of the same basic format, one for each of the four equipment categories, were prepared for this survey. These questionnaires appear in Appendix. B and include the equipment lists described in Sect. 3.2.

The questionnaires were designed to provide answers to the following questions:

1. Is equipment avallable to meet the specified process conditions? if not, what are the limiting factors?

2. What maintenance requirements and problems are expected during the operation of each item of equipment?

In the following discussion it may be useful to refer to the actual questions in the questionnaires.

The following paragraphs were designed to answer the first of these primary questions. Availability of the equipment, its type, and the associated components of its drive train are considered.

The question on Availability addresses the key objective of this survey, determining the potential of U.S. industry to supply rotating equipment for demonstration and commercial coal conversion facflities. To facilitate the response procedure and to categorize the various possibilities that might have been encountered, an availability code was prepared, which includes predefined coded responses. This code is presented in Table 4.

The question on Largest Capacity seeks to supplement the response on availability. The manufacturer's response indicates whether or not he has experience in building equipment to meet. the process requirements of a given application and, perhaps, that this equipment might actually have been larger than the equipment specified in this study. If 1 t were smaller, the amount of scale-up required could be determined.

Responses to the question on Limiting Factors were intended to focus attention on the key factors limiting the avallability of equipment. For those applications for which equipment is not presently available, it 
Table 4. Availability codes

\begin{tabular}{|c|c|}
\hline Code & Description \\
\hline \multicolumn{2}{|r|}{ Available equipment } \\
\hline A1 & Available off-the-shelf equipment produced by our company. \\
\hline A2 & Equipment available by special order through our company.' \\
\hline A $3^{\prime}$ & $\begin{array}{l}\text { Equipment not presently available through our company but } \\
\text { believed to be available within the industry. } \\
\text { Technology available for scale-up }\end{array}$ \\
\hline B1 & $\begin{array}{l}\text { Equipment is not presently available through our company but } \\
\text { technology is available in-house wh1ch will likely be used if } \\
\text { market forces are attractive. }\end{array}$ \\
\hline \multirow[t]{2}{*}{ B2 } & $\begin{array}{l}\text { Equipment is not presently available through our company but } \\
\text { technology is available within the industry which will likely be } \\
\text { used by one or more companies if market forces are attractive. }\end{array}$ \\
\hline & Anticipated technology by 1982 \\
\hline $\mathrm{Cl}$ & $\begin{array}{l}\text { Anticipated technology requiring } R \& D \text { which will likely be } \\
\text { funded by our company if market. forces are attractive. }\end{array}$ \\
\hline $\mathrm{C} 2$ & $\begin{array}{l}\text { Anticipated technology requiring } R \& D \text { which can be funded by } \\
\text { industry if market forces are attractive. }\end{array}$ \\
\hline $\mathrm{C} 3$ & $\begin{array}{l}\text { Anticipated technology requiring } R \& D \text { which can be handled } \\
\text { through our company provided governmental assistance is } \\
\text { available. }\end{array}$ \\
\hline $\mathrm{C4}$ & $\begin{array}{l}\text { Anticipated technology requiring } R \& D \text { which can be handled within } \\
\text { the industry provided governmental assistance is available. }\end{array}$ \\
\hline & Anticipated technology: 1982 to 1987 \\
\hline D1 & $\begin{array}{l}\text { Very advanced future technology requiring extenstve R\&D which. } \\
\text { is likely to be handled by industry by } 1987 \text { without governmental } \\
\text { assistance. }\end{array}$ \\
\hline D2 & $\begin{array}{l}\text { Very advanced future technology requiring extensive R\&D which } \\
\text { requires governmental assistance for development by } 1987 .\end{array}$ \\
\hline & Questionable technology \\
\hline E1 & Technology not believed possible before 1987. \\
\hline E2 & $\begin{array}{c}\text { Technology not believed possible for these conditions. } \\
\text { Inapplicable }\end{array}$ \\
\hline F1 & $\begin{array}{l}\text { None of the above codes are applicable or appropriate for our } \\
\text { firm to use. Insert a footnote in column } 14 \text { for additional } \\
\text { comments, i.f so desired. }\end{array}$ \\
\hline
\end{tabular}


.was of interest to know what factors limited availability. Such factors would primarily involve physical limitations such as temperatures, pressures, flow rates and stream composition, or combinations of such factors.

At this point in the pump and compressor questionnaires, a qualifying statement was included. Responses to the remaining questions in these questionnaires were to be made with respect to the equipment size indicated by the manufacturer if his largest capacity exceeded that which had been specified in the equipment list under Flow Rate; otherwise, responses were to be based on the capacity under Flow Rate. It was assumed that smaller equipment was available if the manufacturer could make the larger unit; information was desired on the larger unit to establish more firmly the capability of the manufacutrer. This qualifier was not included in the hydraulic turbine and gas expander questionnaires; all answers were to be based on the specified flow rate.

Responses to the question on Equipment Type indicated the type of equipment which the manufacturer could build for the specified application; that is, for a compressor application, a centrifugal or axial type might be used. In addition to rotating-machine types, reciprocating machines were also included in this survey.

The question on Stages allowed for refinement and comparison of the responses to the preceding question by allowing the manufacturers to indicate the number of stages required to provide the specified pressure rise. Responses to this question may also indicate that the placing of several multistage units in series may be required.

The Recommended Driver for an item of equipment may depend on conditions imposed by the customer; however, the choice of the driver might be left to the manufacturer. The recommendation of the latter was sought. 'lhis question applled only to pumps and compressors.

Information on the type of Load and Speed Control suitable for preventing runaway of hydralic turbines and gas expanders was requested.

A question on Estimated Efficiency was added to the questionnaires on turbines and expanders to secure an indication of the efficiency of power recovery. Pump and compressor questionnaires, which had been 
prepared earlier, did not include this question, although it would have been desirable to know the efficiency of power usage.

The Recommended Intermediate Transmission (coupling) prepared for a driver-rotating equipment system was requested to more fully characterize the proposed equipment train.

Catalogs were requested to supplement responses previously made.

The next several questions in the questionnaires highlight maintenance requirements and focus attention on problem areas that might be encountered during operation of each equipment item. These data indicate (1) where possible improvements to existing designs can be made and (2) potential problems to be dealt with in the development of new equipment.

Absolute maintenance costs are not very beneficial unless the purchase price of the equipment is also available. Because it is not possible to assess accurately the price of equipment items yet to be developed, it was assumed that Anticipated Maintenance Costs should, in some manner, be related to initial costs. It was also assumed that maintenance requirements, such as the need and frequency of replacing parts, might be postulated for those items. If these assumptions are acceptable, the price of parts relative to a new unit can be approximated and, eventually, maintenance costs estimated for the first 10 years. Once these costs are established, an average 1-year maintenance cost can be expressed as a percentage of the initial purchase price. For those items of equipment similar to existing machines, the determination of maintenance costs is readily accomplished.

In-Service Availability, a measure of the fraction of time a machine will be available for its intended use, indicates both the need for spares and time required for maintenance. In-service availability and maintenance costs are inversely related.

The question on Problem Areas highlights the problems affecting in-service availability and maintenance costs. It indicates areas in which (1) possible improvements to existing equipment designs can be made and (2) research and development work should be concentrated during the design of new equipment. 
The overall time frame in which equipment becomes available for installation in coal conversion facilities was addressed previously by the initial question on availability. The next two questions refine this first question on equipment availability by indicating lead time required to develop (if necessary) and build the equipment. :-

Delivery Time is the time from the order of equipment (which needs no developmental work) through the time of its installation and checkout in the coal conversion facility.

Development Lead Time is the time required to do research and development work necessary lu llake equipment availablo on a sposta1nrier basis,

A provision was made to allow manufactuiers to include any Additional Comments they considered appropriate.

The question on Capabilities and Quantitles was asked independently of any particular application; it sought an industry assessment of its capabilities to meet increased demand for rotating equipment which could occur if a number of coal conversion facilfties were under construction. This question is of limited usefulness because the demand picture is not clear.

Other questions might also have been asked; however, those presented above give significant information with whlch to weet the objecm tives of this study.

\subsection{Manufacturers}

The reliability of this study is dependent to a great degree on responses of manufacturers to the questionnalres. It was important, therefore, to contact a large cross section of U.S. Industry and Lu enlist its expertise to determine industry's actual capabilities. Four primary sources were used to compile the 11st of manufacturers to receive questionnaires: Chemical Engineering Catalog, ${ }^{1}$ Hydraulics Institute list of members, ${ }^{2}$ ThomCat, ${ }^{3}$ and VSMF. ${ }^{4}$ Lists of manufacturers from these sources were compared and a final list complled of those to 
whom questionnaires would be sent. ${ }^{*}$ Table 5 summarizes the number of questionnaires sent to industry and the number of responses received. A list of manufacturers responding to the questionnaires appears as Appendix D.

In addition to the information received in response to the questionnaires, a number of visits, which ylelded much beneficlal information, were made to archttect-engineering firms, users of rotating equipment, and manufacturers. A Itst of those visited is provided in Table 6 . During visits with manufacturers, information was obtalned that supplemented and expanded the data provided in their responses to the questionnalres; their manufacturing facilities were also toured. Discussions held with architect-engineers and users of rotating equipment Indicate that responses have been recelved from nearly all of the firstIine equipment vendors. It is therefore concluded that rellable Information has been obtained.

Table 5. Summary of industry coverage and response to equipment questionnalres

(A' questionnalre was occasionally sent to several different divistons of the same company; likewise, several responses, to a questionnalre were sometimes recelved from different divisions of the same company.)

\begin{tabular}{|c|c|c|c|c|}
\hline \multirow{2}{*}{$\begin{array}{r}. \\
. \\
. \\
.\end{array}$} & \multicolumn{4}{|c|}{ Equipment category } \\
\hline & Pumps: & Compressors & $\begin{array}{l}\text { Hydraulic } \\
\text { turbines }\end{array}$ & Gas \\
\hline $\begin{array}{l}\text { Questionnatres } \\
\text { sent }\end{array}$ & $80^{\circ}$ & 49 & 67 & 26 \\
\hline $\begin{array}{l}\text { Responses } \\
\text { recelved }\end{array}$ & 26 & 18 & 5 & 8 \\
\hline
\end{tabular}

"In addition to U.S. manufacturers, several European firms having offices in the United States also recelved and responded to the questionnaires. 
Table 6. Site visits or meetings in Oak. Ridge

\begin{tabular}{|c|c|c|c|c|}
\hline \multirow[b]{2}{*}{$\cdot$} & \multicolumn{4}{|c|}{ Diccission topics } \\
\hline & Pumps & Compressors & Turbines & Expanders \\
\hline Architect engireers & & & & \\
\hline $\begin{array}{l}\text { Stearns-Roger (Derver, Colo.) } \\
\text { Ralph M. Parsons (Pasadena, Calif.) }\end{array}$ & $\begin{array}{l}x \\
x\end{array}$ & $\begin{array}{l}\mathbf{x} \\
\mathbf{x}\end{array}$ & $\begin{array}{l}\mathbf{x} \\
\mathbf{x}\end{array}$ & $\begin{array}{l}\mathbf{x} \\
\mathbf{x}\end{array}$ \\
\hline Users . & & & . & \\
\hline $\begin{array}{l}\text { Union Carbide, Chemicals and Plastics } \\
\text { Division (Taft, La.) } \\
\text { Charter Oil (Houston, Tex.) } \\
\text { Exxon (Baytown, Tex.) }\end{array}$ & $\mathbf{x}$ & $\mathbf{x}$ & $\mathbf{x}:$ & $\begin{array}{l}\mathbf{x} \\
\mathrm{x} \\
\mathrm{x}\end{array}$ \\
\hline Manufacturers & & & & \\
\hline $\begin{array}{l}\text { Airco Cryogenics (Irvine, Calif.) } \\
\text { Worthington (Bran=ford, Ontario, Canada) }\end{array}$ & $\mathbf{x}$ & $\mathbf{x}$ & & $\mathrm{x}$ \\
\hline $\begin{array}{l}\text { Ingersol1-Rand (Pillipsburg: N.J., and } \\
\text { Allentown, Pa.) }\end{array}$ & $\mathrm{x}$ & $\mathbf{x}$ & & $\mathrm{x}$ \\
\hline Elliott (Jeanette, $\mathrm{Pa}$. ) & & $\mathrm{x}$ & & $\mathrm{x}$ \\
\hline Dresser-Clark (Olean, N.Y.) & & $\mathrm{x}$ & & $\mathrm{x}$ \\
\hline Sulzer (Oak Ridge, Tenn.) & & $\mathrm{x}$ & 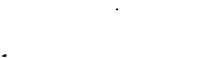 & \\
\hline Bingham-Willamett (Portland, Oreg.) & $\mathrm{x}$ & & $\mathrm{x}$ & \\
\hline United (San Jose, Calif.) & $\mathrm{x}$ & & & \\
\hline Pacific (Los Angeles, Calif.) & $\mathbf{x}$ & & $\mathrm{x}$ & \\
\hline Byron Jackson (Los Angeles, Dalif.) & $\mathrm{x}$ & & $\mathbf{x}$ & \\
\hline Wilson-Snyder (Dallas, Tex.) & $\mathrm{x}$ & & & \\
\hline $\begin{array}{l}\text { American Denag (New York, N.Y.) } \\
\text { Allis Chalmers (York, Pa.). }\end{array}$ & & $\mathrm{x}$ & $\mathbf{x}$ & \\
\hline Mechanical Iechnclogy (Oak Ridge, Tenn.) & & $\mathbf{x}$ & & $\mathbf{x}$ \\
\hline
\end{tabular}




\section{SURVEY RESULTS}

A total of 57 responses to the various questionnaires was recelved from industry. The data contained in these responses and information received during visits, meetings, and phone conversations with manufacturers are presented in the following subsections, each dealing with one of the four equipment categories. The order of presentation in each of these subsections begins with availability, proceeds to problem areas and solutions, and concludes with research and development needs as percelved by the manufacturers. Analysis of the data is not undertaken in this section; therefore, conflicting opinions appear in the text. Responses from manufacturers to the questions on availability and largest capacities (questions 1 and 2 in the questionnaires) are tabulated in Appendix E.

\subsection{Pumps}

Twenty-six responses to the questionnaire on pumps were received from a number of companies, representing a broad cross section of the industry. Many of these companies have experience in supplying pumps for both the petrochemical and nuclear industries, which have stringent requirements concerning design and manufacture to ensure high reliability and safe operation. Manufacturers of both centrifugal and reciprocating pumps provided information. Several of the responding companies specialize in slurry pumps; however, these companies generally supply sing1estage pumps for low-head applications.

\section{Availability}

Responses of manufacturers to the pump questionnaire indicate that pumps are available for all specified applications. In many cases pumps are available from a number of manufacturers, which is particularly true for clean-liquid applications. However, discussions subsequent to receipt of responses have raised questions as to the actual availability of pumps for slurry applications. Table 7 summarizes the number of manufacturers indicating their capability to supply equipment for the various 
classes of pump applications either on an off-the-shelf basis or by special order.

Table 7. Completeness of coverage as reported by vendors

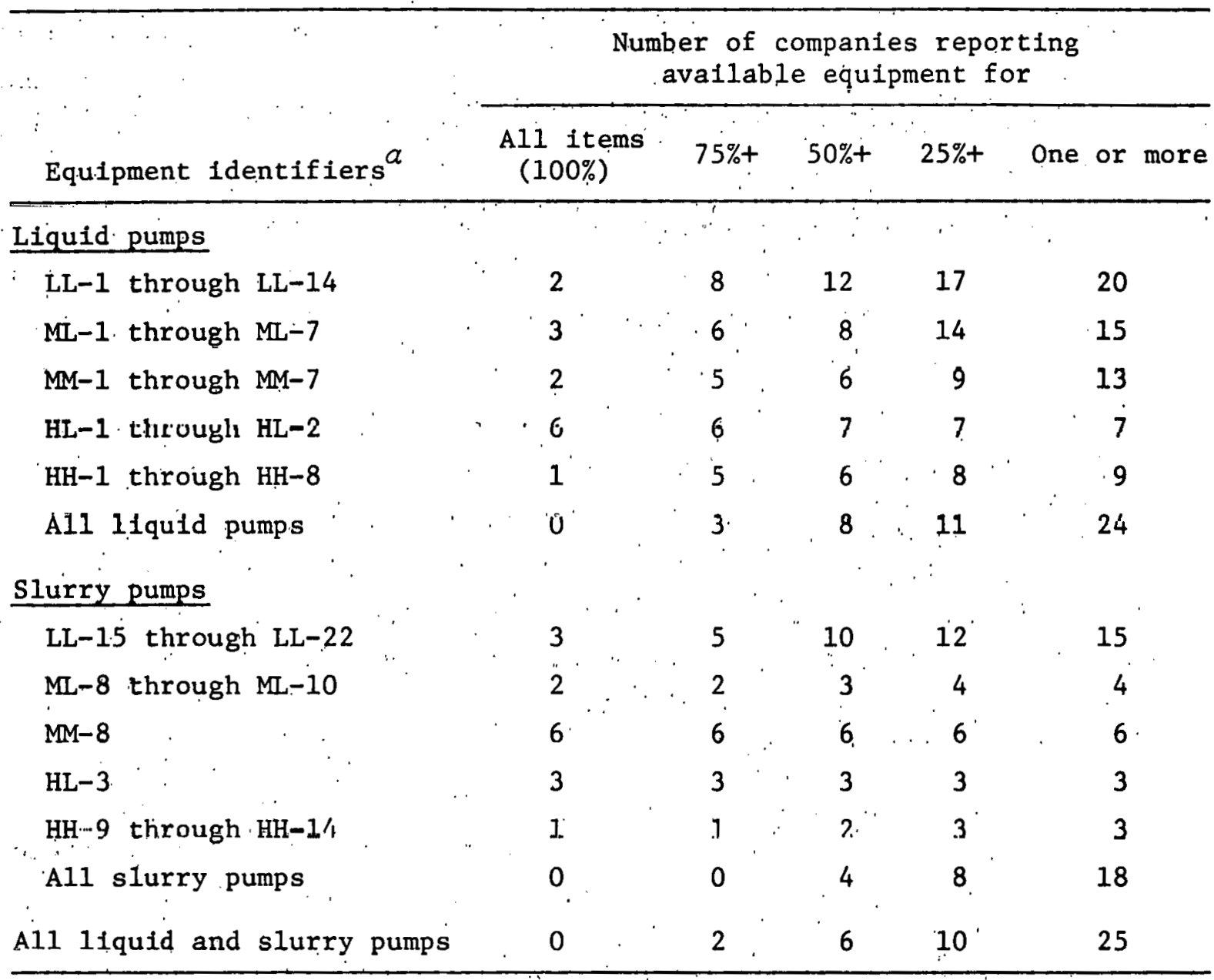

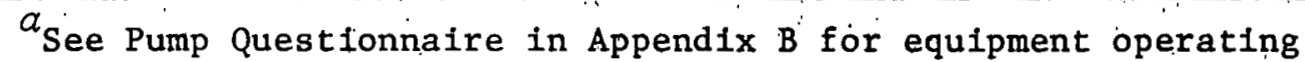
conditions.

Although only a few manufacturers provide pumps for all of the appiications in a given category, generally a much 1arger number of manufacturers make $75 \%$ or more of the pumps. For instance, only one company builds equipment for all of the high-outlet-pressure, high-head, cleanliquid pump applications represented by $\mathrm{HH}-1$ through $\mathrm{HH}-8 ;{ }^{*}$. however,

\footnotetext{
* See Pump Questionnaire in Appendix B for equipment operating conditịons .
} 
five.companies produce pumps for at least $75 \%$ of the applications, six companies provide $50 \%$, and nine companies supply one or more.

Four or more vendors indicated the capability of providing a pump for each clean-liquid application except HH-4. Only one manufacturer indicated having equipment available for this application; however, four other manufacturers have information available in-house for scale-up and stated that this would be an easy application to fill. Furthermore, this application is identical to $\mathrm{HH}-3$ except that the flow rate is twice that required by $\mathrm{HH}-3$. Four companies indicated they could supply equipment for HH-3. Comments from vendors during follow-up discussions supported their initial response that equipment is readily available for all the clean-liquid applications.

Slurry pumps, although less available than clean-liquid pumps, are also available from a number of manufacturers in certain instances, such as the low-outlet-pressure, low-head applications represented by LL-is through LL-22. These applications are expected to require only singlestage centrifugal pumps. Comments from throughout the industry indicate that single-stage slurry pumps are available for heads of as much as about 100 psi; however, reservations have been expressed by one manufacturer on the availability of such pumps for high-temperature oil slurries. The reason for concern is the potential problem of thermal shock resulting in the breakage of the very hard material used in those areas of the pumps where ductile materials would normally be used.

The high-outlet-pressure, high-head slurry pumps, represented by applications $\mathrm{HH}-9$ through $\mathrm{HH}-14$, require multistage centrifugal or positive displacement pumps, which are either nonexistent or uncommon respectively. Only three companies, two reciprocating pump manufacturers and one centrifugal pump manufacturer, indicated that equipment was currently available for these applications. The centrifugal pump manufacturer decided during subsequent discussions that his indication of capability to provide equipment for these applications was premature. The two reciprocating pump manufacturers specified use of multiple units in making their claim of having equipment for these high-pressure, high-head slurry applications. Since reclprocating pumps are available only in sizes of up to 3000 to $4000 \mathrm{hp}$, the use of multiple units must be accepted to have pumps for all individual slurry pump applications at this time. 
Several general statements were received in follow-up visits with manufacturers relative to the availability of slurry pumps. Although several of these statements are conflicting, they are presented as input to this study.

- Slurry concentrations of more than about 40 wt \% solids will require reciprocating pumps.

- High-pressure slurry applications should use reciprocating pumps.

- Reciprocating pumps are available for 3000-psi outlet pressure.

- Centrifugal pumps, even with staging, are limited to an outlet pressurc of about 600 to 800 pisia.

- The maximum pressure rise per stage for centrifugal pumps is limited to about 100 psi per stage.

- A technology breakthrough allowing increased pressure rise per stage is needed for centrifugal pumps.

- Impeller-tip velocities in centrifugal slurry pumps are limited to a maximum of $100 \mathrm{fps}$. (This yields, approximately, the 100-psi per stage pressure rise.) One centrifugal pump manufacturer designs for maximum velocities of about $70 \mathrm{fps}$.

- Multistaging of centrifugals to handle slurries will be difficult.

- There is a trend toward using centrifugal pumps for slurry applications.

- Centrifugals are desired.

- Evencually, bul uut immediatcly, contrifugal pumps may he developed for 1 year of continuous operation.

Problem Areas and Proposed Solutions

The response of manufacturers to the question on problem areas was considered to be good. Problem areas were generally stated only by manufacturers who either have equipment available for a given application or appear likely to be among the first to have equipment available. Problem areas were stated for approximately one-half of the applicatiuns, for which responses were also provided for most. of the other questions in the questionnaire. Since the most severe problem area for a given pump was requested, the stated problem might aclually be minor. A summary of the problem areas reported by manufacturers is provided in Table 8 . 
Table 8. Problem areas reported by pump manufacturers

\begin{tabular}{|c|c|c|c|c|c|c|c|c|c|c|c|c|c|}
\hline \multirow{2}{*}{$\begin{array}{c}\text { Equipment } \\
\text { identifier }\end{array}$} & \multicolumn{13}{|c|}{ Problem areas $^{a}$} \\
\hline & Corrosion & Erosion & Pitting & Deposits & Plugging & Bearings & Cavitation & Seals & Couplings & Vibration & Drivers & $\begin{array}{l}\text { Intermediate } \\
\text { transmission }\end{array}$ & other ${ }^{c}$ \\
\hline \multicolumn{14}{|l|}{ Liquid pumps } \\
\hline LL-1 through LL-14 & 14 & 18 & & & & 26 & 35 & 33 & & 9 & & & 2 \\
\hline ML-1 through ML-7 & 9 & 10 & & & & 11 & 21 & 16 & & 6 & 2 & & 2 \\
\hline MM-1 through MM-7 & 7 & 5 & & 2 & & 10 & 20 & 14 & 3 & 4 & & & 7 \\
\hline $\mathrm{HI}-1$ through $\mathrm{HL}-2$ & & & & & & 4 & 4 & 5 & & 2 & & & \\
\hline HH-1 through HH-8 & $\underline{6}$ & 3 & & - & & $\underline{8}$ & 25 & $\underline{17}$ & _ & - & 1 & & $\underline{9}^{\circ}$ \\
\hline All liquid pumps & 36 & 36 & & 2 & & 59 & 107 & 85 & 3 & 21 & 3 & & \\
\hline \multicolumn{14}{|l|}{ Slurry pumps } \\
\hline LL-15 through LL-22 & 15 & 53 & 7 & & 5 & 9 & 9 & 10 & & & & & 1 \\
\hline ML-8 through ML-10 & 3 & 16 & 6 & 2 & & 4 & 3 & 6 & & & & & \\
\hline MM-8 & & 4 & & & 1 & 1 & & 1 & & $i$ & & & 4 \\
\hline $\mathrm{HL}-3$ & 1 & 4 & & & & 3 & $\dot{4}$ & 4 & & 1 & & & \\
\hline HH-9 through HH-14 & - & $\underline{22}$ & $\underline{5}$ & - & - & 一 & - & $\underline{11}$ & & - & & & $\underline{18}$ \\
\hline All slurry pumps & 19 & 99 & 18 & 2 & 6 & 17 & 16 & 32 & & 2 & & & \\
\hline
\end{tabular}

Numbers appearing in the table represent the total number of times that a particular problem area was cited for a given category of pumps. For example, one manufazturer cited cavitation as a problem for all 14 pumps in the L1quid pump LL category, another cited cayitation 11 times, one for five pumps, and two each for one or two pumps. Cavitation was cited as a problem for the LL group 36 times and was c1ted as a problem at least twice for each of these $L$ i pumps, five times in one instance.

${ }^{b}$ See Pump Ques:ionnaire in Appendix B for equipment operating conditions.

${ }^{c}$ The other problem area includes vane replacement. (2 times), valves (17), plungers (12), and packing (12). All of these areas except vane replacement refer to reciprocating pumps. 
For clean-liquid centrifugal pumps, cavitation was the most frequently mentioned problem, but this problem can be avoided by matching the pump design to the available net positive suction head (NPSH) at the pump inlet. When necessary, a charge pump (a pump designed for low available NPSH) should be used to provide sufficient NPSH for the primary pump. Bearings and seals were also frequently mentioned as problem areas. Follow-up comments indicated that these problems can be handled satisfactorily by use of the latest available technology in these areas. Use of separate seal-oil and lube-oil systems could be important in allev1ating these last problems, although this would be more expensive initially. Seal isolation has also been suggested for hot-oil pumps.

Erosion was the problem mentioned most with respect to slurry pumps. Lower velocities in centrifugal slurry pumps were frequently mentioned as a means of handling slurries with currently available construction materials. Impeller-tip velocities of no more than $100 \mathrm{fps}$ is a ruleof-thumb maximum generally accepted within the industry for very abrasive slurries; maximum velocities of no more than $70 \mathrm{fps}$ were recommended by one manufacturer who is currently selling slurry pumps to the petroleum and coal conversion industries. Typically, centrifugal slurry pumps are relatively slow-running machines when compared to clean-liquid pumps. Larger pump diameters were suggested to compensate for head loss caused by. lower operating speeds. Operation of centrifugal slurry pumps in a narrow band around the maximum efficlency point will prolong the 11fe of such pumps by minimizing turbulence and backflow, which result in excessive wear rates. Improved hydraulic design may also be possible; this, too, can reduce wear rates.

Variable-speed drivers to permit speed adjustment as pumps wear have been suggested to maintain pumping characteristics and to prolong pump life. Axial adjustment of pump shafts might also be a means of maintaining interstage seal clearances as seals wear. Easily removable internal-wear components were recommended by most manufacturers: Such recommendations vary from use of easily replaceable "subparts" in highwear areas such as volute tips to frequent replacement of all internal parts. These subparts would normally be an integral part of some larger component in a clean-liquid pump. Use of the most advanced materials and coatings was suggested. 
The most severe problem of reciprocating slurry pumps is wear of sliding parts and valves. Wear is presently tolerated by use of designs that permit rapid replacement of worn parts. To permit repairs while maintaining continuous operation, multiple units are required. One spare is generally installed for one to elght required units. As they are developed, the application of better materials in valves, plungers, and packings has been recommended to improve the wear characteristics of reciprocating pumps.

Research and Development Needs

No research and development needs were reported for clean-1iquid pumps. Some manufacturers may do some testing as they use scale-up information to develop their own line of equipment for applications for which equipment is already available from other vendors.

For slurry applications, the development of better materials has been suggested for both reciprocating and centrifugal-type slurry pumps. Test facilities have been suggested for evaluating the performance and wear characteristics of currently available clean-liquid multistage pumps on abrasive slurries. Identification of hydraulic and wear problems through such testing is needed to determine the starting point for modifying present-generation multistage pumps to handle slurries; reportedly, points of expected wear sometimes fail to materialize, while other points may wear severely.

A widespread belief exists throughout the Industry that multistage centrifugal pumps need to be developed for coal conversion applications. This seems to be prevalent among equipment manufacturers and users with experience in the operation of smooth-running centrifugal pumps on clean liquids. On the other hand, those experienced with the reliability of reciprocating pumps, with spares installed to minimize the effects of maintenance may prefer reciprocating machines. This latter group believes that improvements in materials will benefit both reciprocating and centrifugal tnachines and perhaps maintain a competitive edge. for reciprocating machines. 
Scale-up of existing reciprocating pumps to about 6000 to $7000 \mathrm{hp}$ has been suggested as a means of reducing the large number of units in parallel, which is often required to meet capacity requirements. This might also reduce the initial and maintenance costs associated with reciprocating machines to more reasonable levels. One manufacturer has suggested that additional work needs to be done to develop reliable, single-stage slurry pumps for hot-oil applications.

\subsection{Compressors}

Compressors are used in many different industries for a variety of purposes; the manufacturers of this type of equipment generally tend to specialize their product line within a reasonably consistent range of specific applications, for example, air conditioning and refrigeration compressors, air compressors over a wide range of sizes, etc. Responses to the compressor questionnaire were obtained from 18 manufacturers, most of whom specialize in equipment for the petrochemical industry. Because of the wide range of compressor applications encountered in this industry, no manufacturer stocks machines for immediate delivery; instead, each item of equipment is designed and built to order for a specific application. The manufacturers' assessments of their capab1lities to supply compressors for the coal conversion industry is considered in this subsection.

\section{Availability}

of the 40 individual compressor applications, all but 7 can be supplied by one or more of the 18 manufacturers on a special-order basis, with deliveries ranging from 15 to 24 months. Volumetric flow and discharge pressure are two of the most signifiçant parameters in determining the size, type, and availability of compressors for these applications. Figure 3 shows the location of each of the 40 applications on a plot of discharge pressure vs volumetric flow. The numeral adjacent to each point shows the number of manufacturers who indicated the capability to provide a full-capacity compressor for that application. These numbers tend to be highest near the middle of the figure; they decrease rapidly 
OANL-DWG 78.2420

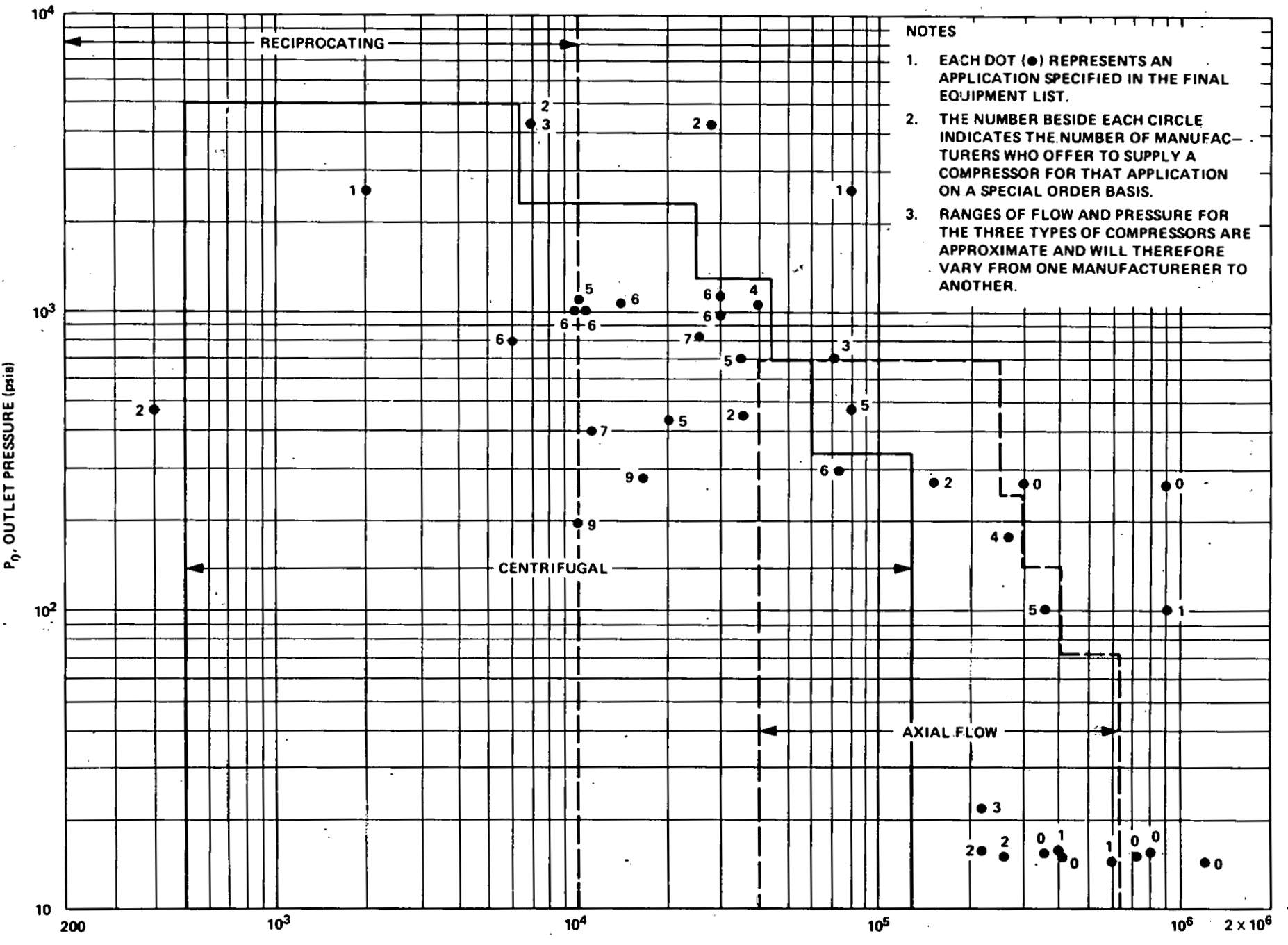

$Q_{i,}$ INLET FLOW RATE (actm)

Fig. 3. Compressor type as a function of inlet flow rate and outlet pressure. 
at the highest levels of flow and pressure. Table 9 presents these same data by identifier.

As indicated by Fig. 3, several distinct types of compressors are required to cover the wide range of pressures and flows. Positive displacement compressors can be used over the entire range of pressures for volumetric flows of up to about 10,000 acfm. Centrifugal compressors are applicable from approximately 500 acfm to more than 100,000 acfm. Axial flow compressors are used. for the highest levels of volumetric flow, including flows in excess of $1,000,000 \mathrm{acfm}$ in some favorable cases.

As volume flow and discharge pressure are increased, compressors become larger and heavier. There are limits, both economic and practical, to the size and weight of compressor components that can be manufactured, shipped, and installed. The maximum pressure for which compressors are normally available therefore decreases with increasing volumetric flow, approximately as indicated in Fig. 3. Because of the large number of variables that can enter into compressor design and manufacture, appreciable deviations from the maximum pressure levels indicated in the figure may occur for specific individual applications:

Table 9 shows that none of the low-pressure, low-pressure-ratio fans and blowers 1isted under identifiers FB-1 through FB-9* are offered on a ful1-capactity, specia1-order basis by more than two manufacturets. One of these manufacturers is a German firm. The maximum discharge pressures for these machines range between 14.7 and 15.8 psia, and pressure ratios vary from 1.03 to 1.09 . These blowers or fans are large in size but relatively light. in weight. Few companies are set up to build such equipment. Axlal-flow machines were specified by both manufacturers for Identifiers $\mathrm{FB}-1$ through $\mathrm{FB}-5$, which handie relatively clean gas streatts.

Particulate contents of 0.5 to 1.5 grains per actual cubic foot were spectified for identifiers FB-6 through FB-9, and the manufacturers recommend that centrifugal compressors be used for these four applications because the relatively thin blades used in axial flow compressors would suffer excessive erosion from impingement of the particulates. Maximum volumetric flows for centrifugal machines of the double-flow type would probably be limited to about 350,000 acfm vs the specified

\footnotetext{
* See Compressor Questionnaire in Appendix B for equipment operating conditions.
} 
Table 9. Sumnary of availability of compressors

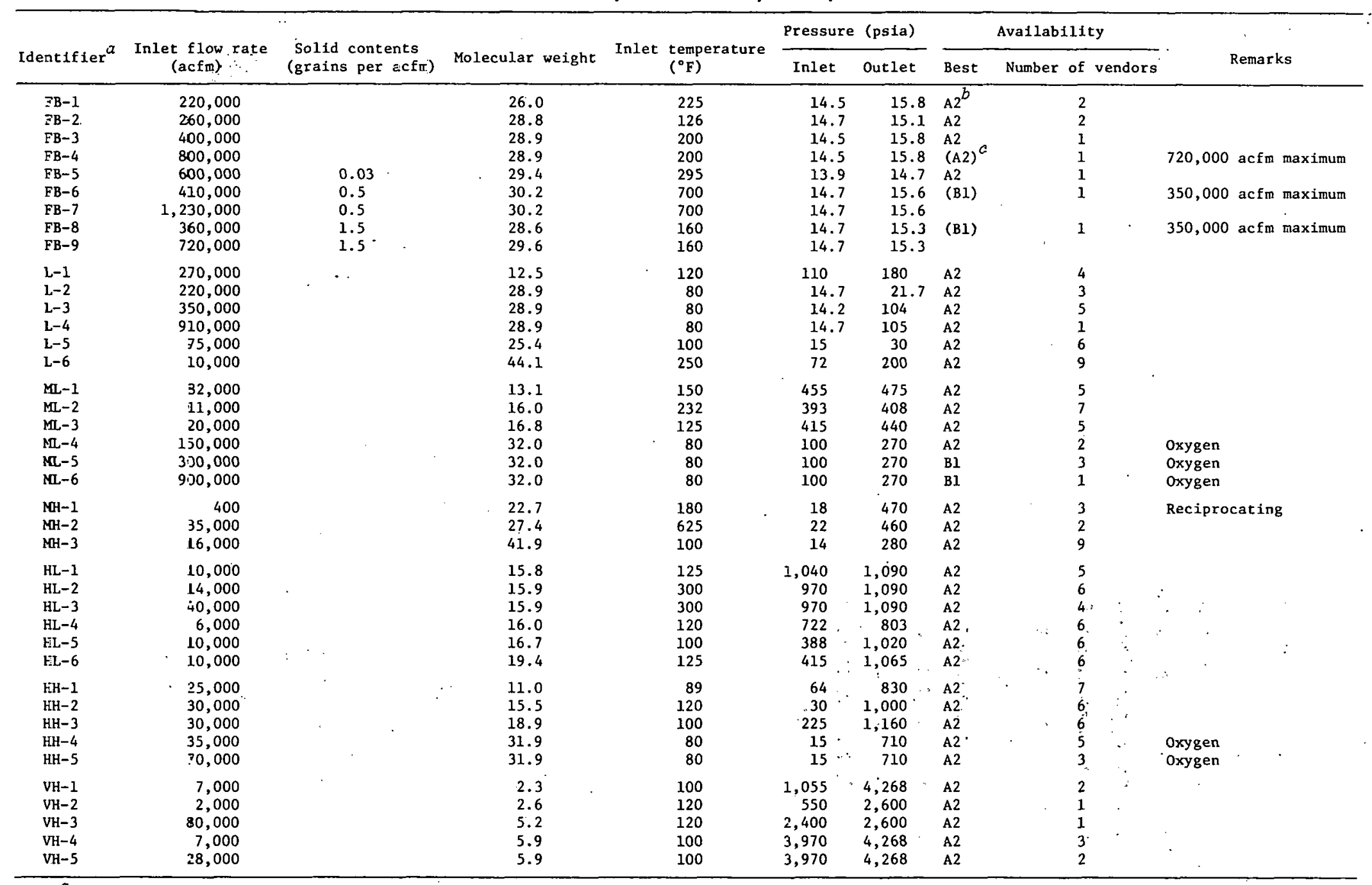

${ }^{a}$ See Compressor Questionnaire in Appendix B for other equipment operating conditions.

${ }_{\mathrm{A}}$ indicates equipment is avallable from the responding company; B1 indicates equipment will be available from the responding company.

${ }^{c}$ For avallability codes in parentheses, seel Remarks, column for maximum flow rate of proposed equipment. 
capacities of 360,000 to $1,230,000$ acfm. An additional problem is involved for applications FB-6 and FB-7; the inlet temperatures are specified as $700^{\circ} \mathrm{F}$. Although it is feasible to build compressors for gas temperatures of this level, it is anticipated that high temperatures might aggravate the erosive effects of the particulates. In summary, applications FB-6 through FB-9 may be difficult to obtain at the specified capacity levels.

While two manufacturers offer to supply oxygen compressors ML-4 on a special-order basis, ML- 3 and ML- 6 will be more difficult to obtain. $\Lambda 11$ three applications are identical except for volumetric flow. A review of the proposed applications for these compressors indicates that an initial misinterpretation of the process requirements resulted in the flow levels for ML- 5 and ML- 6 being overstated by a factor of 32 . ML-4 as presented in the questionnaire should therefore provide adequate capacity for any of the corrected applications.

\section{$\underline{\text { Problem Areas }}$}

Responses of the various manufacturers to the Problem Areas column of the questionnaire were not uniform. Many of them left the column blank in virtually all instances, but a few included an entry for almost every application. Subsequent discussions, primarily with the manufacturers of large compressors for the process industries, indicated that their evaluations of potential problems were far more uniform than was at first interpreted from their written responses. This subject will be discussed further in Sect. 5.2 under problem areas.

\subsection{Hydraulic Turbines}

llydraulic turtines are supplied by manufacturers who specialize in hydroturbines for power generation at hydroelectric dams and by centrifugal pump vendors who generally offer their pumps as hydraulic turbines by operating them in reverse rotation. A number of companies formerly specialized in the hydroturbine field; however, as the size of these power production units became larger, many of these companies discontinued manufacturing hydraulic turbines because of decreased demand and 
intense foreign competition. Currently, there are only two domestic hydroturbine manufacturers, one of which, Allis-Chalmers, responded to the hydraulic turbine questionnaire. Three pump manufacturers also responded as well as one hydraulic motor manufacturer, whose offerings were limited. Thus five responses were received to the hydraulic turbine questionnaire.

Availability

Most of the hydroturbines now produced by Allis-Chalmers are used for hydropower generation. These turbines are considerably larger than would be required for coal conversion plants; however, in the past, they have made smaller turbines that are more nearly compatible with coal conversion plant requirements. Many of the old drawings for these smaller units are still extant and may be revised for present applications with minimal effort. Furthermore, the significant advances made in increasing turbine efficiency can be applied to these small turbines once they are again manufactured. The reversible pump/turbine units manufactured by Allis-Chalmers have an efficiency of 91 to $92 \%$ when operated in either mode. This is approximately ten percentage points better than the pumps operated in reverse which are supplied by centrifugal pump manufacturers.

The need for hydraulic power recovery equipment in the chemical process and petroleum industries has been satisfied recently by pumps running in reverse rotation. The only modification made to pumps so used is the installation of an impeller ${ }^{*}$ different from that used for the pumping mode.

Two of the three responding centrifugal pump manufacturers offered single or multistage units for each of the specified clean-liquid applications. The third company and the other domestic hydroturbine manufacturer (who was contacted by phone) indicated that they could supply machines for approximately one-half of these applications. These latter

* Runner is the proper terminology for hydraulic turbines. 
companies indicated that technology should also be available for the other applications.

Hydraulic turbines for slurry applications are less available than are turbines for clean-liquid applications. Alternate suppliers exist only for applications $\mathrm{T}-18$ and $\mathrm{T}-19 .^{*}$ One vendor initially indicated that he had available equipment for applications T-20 through T-24 but later expressed reservations. One. or two other companies have in-house scale-up technology for these applications.

Equipment for applications $\mathrm{T}-25$ and $\mathrm{T}-26$ was not listed as available in any response. One company believes that it has the necessary information to develop and produce this equipment if market demand is sufficient; this claim was supported by another vendor who indicated that such technology should be available within the industry. Two other companies indicated that 5 to 10 years would be required to make such equipment available; this development may or may not require government funding, depending on market demand.

Francis-type turbines (including centrifugal pumps run in reverse rotation) have generally been suggested for the 26 hydraulic turbine applications. Allis-Chalmers suggested, however, that impulse (Pelton) turbines may be best suited for slurry applications, provided the back pressure on the unit is low. 'l'he buckets of the Peilton wheel w111 be subjected to severe erosion but can be replaced readily.

\section{Problem Areas and Proposed Solutions}

Technical problems reported for hydraulic turbines were generally the same as those reported for pumps. No significant problems appeared for clean-1iquid applications; however, care must be taken to maintain the outlet pressure high enough to prevent cavitation. For slurry applications, erosion is a significant problem; however, slurry pump technology, as it is developed, can be applied to hydraulic turbines.

\footnotetext{
* See Hydraulic Turbine Questionnaire in Appendix B for equipment operating conditions.
} 
Research and Development Needs

Although hydraulic turbines are avallable for clean-1iquid applicatIons, Improved designs would increase efficiency:

Materlals research 1s required to develop better materials for slurry applications.

\subsection{Gas Expanders}

Gas expanders are used by industry to recover energy from pressurized gas streams. Primary use of these devices has been in the fluidized catalytic cracking units of petroleum refineries and in nitric acid plants.; The former application must handle particulates that remain entrained In the gas stream even after three stages of cyclones; the latter application Involves a clean gas stream. Eight manufacturers, all of whom supplied Information on compressors, responded to the questionnaire on gas expanders. Conventional steam and gas turbines were not considered in this study.

\section{Ava1lab111ty}

Six different expander applications were speclfled. Equipment for. four of these applications could be supplied on a spectal-order basis by from two to four manufacturers, w1th delivery in 12 to 18 months. A1-... though these applications cover.wide ranges of temperature and pressure (see Identifiers E-1, through $E-4^{*}$. In Table 10), they share one common: characteristic - inlet temperatures are no more than $1200^{\circ} \mathrm{F}$.

Two of the manufacturers propose radial inflow expanders for applications E-1 through E-3; only one of them proposes the same type of machine for application E-4. A third vendor specifled axial flow expanders for each of these four cases; a fourth would supply lobe-type machines, which he proposes for E-2 and E-3.

Equipment for the remaining applications (E-5 and E-6) is not currently avallable because of the high inlet temperatures $\left(1657^{\circ} \mathrm{F} ; \mathrm{E}-5\right.$;

\footnotetext{
* See Gas Expander Questionnaire in Appendix B for equipment operating conditions.
} 
Table 10. Estmated delivery periods for hot-gas expanders

\begin{tabular}{|c|c|c|c|c|c|c|c|c|c|}
\hline \multirow[b]{2}{*}{ Identif ter ${ }^{a}$} & \multirow[b]{2}{*}{$\begin{array}{l}\text { Inlet flow rate } \\
(\text { acfm) }\end{array}$} & \multirow[b]{2}{*}{$\begin{array}{l}\text { Salids content } \\
\text { (grains per acf) }\end{array}$} & \multirow{2}{*}{ Maleculer w?lght } & \multirow[b]{2}{*}{ Inlet } & \multirow[b]{2}{*}{$\begin{array}{l}\text { temperature } \\
\left({ }^{\circ} \mathrm{F}\right)\end{array}$} & \multicolumn{2}{|c|}{ Pressure (psia) } & \multirow[b]{2}{*}{$\begin{array}{l}\text { Maximum output } \\
\text { (hp) }\end{array}$} & \multirow[b]{2}{*}{$\begin{array}{c}\text { Development lead tine } \\
\text { (years) }\end{array}$} \\
\hline & & & & & & Inlet & Outlet & & \\
\hline $\mathrm{E}-1$ & 60 & & $\therefore 3$ & & $: 120$ & 2,400 & 5013 & 1,000 & 0 \\
\hline$E-2$ & 16,000 & & 28.2 & & 135 & 106 & 23 & 12,400 & 0 \\
\hline E-3 & 85,000 & 0.23 & $26 . j$ & & 348 & 120 & 2) & 80,400 & 0 \\
\hline$E-4$ & 85,000 & 0.15 & 33.3 & & 1,200 & 113 & 25 & 63,800 & 0 \\
\hline$E-5-A$ & $1 \dot{5}, 000$ & 3.15 & 23.0 & & 1,657 & 1,095 & 66 & 203,000 & $2.5-7$ \\
\hline$E-5-8$ & 15,000 & 0.16 & 23.0 & & 1,657 & 1,095 & 66 & 203,000 & $2.5-6$ \\
\hline$E-5-C$ & 15,000 & $\cdot 0.016$ & 23.0 & & 1,657 & 1,095 & 66 & 203,000 & $2.5-5.5$ \\
\hline $\mathrm{E}-6-\Lambda$ & 310,000 & 0.15 & 23.0 & & 1,744 & 66 & 25 & 87,400 & $2.5-7$ \\
\hline$E-6-B$ & 310,000 & 0.0075 & 27.0 & & 1,744 & 66 & 25 & $76,400^{\circ}$ & $2.5-5$ \\
\hline$E-6-C$ & 310,000 & 0.00075 & 23.0 & & 1,744 & 66 & 25 & 87,400 & $2.5-5$ \\
\hline
\end{tabular}

${ }^{a}$ See Gas Expander Questionnaire in Appendix B for other equipment operating conditions. 
$\left.1744^{\circ} \mathrm{F}, \mathrm{E}-6\right)$ and the presence of particulates in the gas streams. Estimates of development lead time for these two applications vary from 2.5 to 7 years. Twelve to eighteen months will be required between the order and installation of equipment after it has been developed. Discussions with several vendors indicated that it might be difficult to obtain reli-. able expanders for these applications in less than 6 to 8 years.

\section{$\underline{\text { Problem Areas and Proposed Solutions }}$}

When compared with the other listed applications, E-1 and E-2 are relatively small units working as modest (120 to $135^{\circ} \mathrm{F}$ ) inlet temperatures. The manufacturers did not anticipate any particular service or reliability problems for either of them. Most vendors anticipate some corrosion, erosion, and possibly pitting problems for application E-3, which has an inlet temperature of $348^{\circ} \mathrm{F}$ and a volumetric flow of 85,000 acfm. Problems similar to those for E-3 are also anticipated for application $\dot{E}-4$ $\left(1200^{\circ} \mathrm{F}\right.$ inlet temperature), and the number of vendors offering available equipment drops to two for this higher temperature application.

The still higher temperatures encountered by applications E-5 $\left(1657^{\circ} \mathrm{F}\right)$ and E-6 $\left(1744^{\circ} \mathrm{F}\right)$ pose more severe challenges. Four major U.S. manufacturers of hot-gas expanders appear to agree that the present state of the art limits maximum gas inlet temperatures to about 1350 to $1400^{\circ} \mathrm{F}$ if the life expectancy of the expander blading is to be maintained in the range of from 10,000 to $40,000 \mathrm{hr}$ (i.e., about 1 to 5 years). This temperature limit is valid only for particulate loadings of no more than 0.06 grains per acf.*

Some type of blade cooling is required for operating temperatures above about $1300^{\circ} \mathrm{F}$. Impingement cooling of the blade roots has been used for some expanders operating at temperatures as high as about $1450^{\circ} \mathrm{F}$; however, as temperatures are further increased, more extensive and thorough forms of cooling are required. It will become necessary to keep gas temperature excursions under much closer control, and improved alloys

\footnotetext{
Gas turbines are reported to have much lower tolerances for particulates.
} 
will be required for the expander blades (buckets) or impellers, particularly when particulates are present.

There is a wide variation in the approach of the varlous manufacturers to the problem of entrained particulates. Although some prefer to restrict their activities to particulate-free gas streams, at least four companies have expressed an interest in developing expanders that can handle some level of particulate loading.

Airco Cryogenics is developing a concept for an expander of the radial inflow type, which should be sultable for handling particulateladen gas streams. The concept includes repositioning the gas inlet nozzles and addition of passages for removal of particulates.

The Elliott Company has obtained a patent ${ }^{5}$ for a radial outflow expander that is intended to separate particulates from a hot-gas stream by centrifugal action while simultaneously obtaining some useful work output. A radial outflow stage could be followed by conventional axial flow stages in a multistage unit if required. A working model of the radial outflow stage has been built and is to be tested to determine its flow characteristics with clean gas at low temperatures.

Dresser-Clark, through their licensing arrangements with a German firm, Gutehoffnungshütte AG (GHH), should be able to obtain license rights to an invention by an Austrian company, Elin-Union. This latter organization has developed a method for minimizing the effects of erosion. on the most critical portions of a hot-gas expander blade - by incorporating a "stumble-step" just upstream of the blade. It is understood that Elin-Union has received some patent protection for this concept; however, it is not currently known whether or not a U.S. patent has been granted.

Although formal drawings of the stumble-step concept were not available for review, a brief description of the principle was given by representatives of Dresser-Clark. As the gas approaches the blades of an :expander, it is normally guided through a smooth annular passage whose cross-section changes gradually and continuously, to avoid perturbations in the flow. In the stumble-step concept, an abrupt discontinuity (a step) is introduced just ahead of the first blade row; the step introduces a minor cross flow or eddying of the hot gas, which diverts most of 
the particulates away from the roots and tips of the blades, thus reducing the rate of erosion in this relatively highly stressed area. Prior to each succeeding stage, a step redistributes the particles away from critical areas where they would otherwise accumulate because of centrifugation. At least one expander that incorporated stumble-steps has reportedly accumulated approximately $40,000 \mathrm{hr}$ of successful operation. Some erosion of the leading edges of the first row of stator blades was reported and is believed to have been because of the accidental omission of the first stumble-step.

Ingerso11-Rand representatives discussed results of developmental tests conducted on hot-gas expanders used for fluid catalytic cracking service and furnished copies of two papers. ${ }^{6}, 7$ Ingersoll-Rand devised a method for observing stroboscopically the appearance of rotor blades during expander operation and followed the progress of deterioration caused by particulate-induced erosion. As a result of these tests, it was possible to modify the contours of the blades in critical areas and to increase their thickness, thus minimizing the adverse effects of erosion. Although the modifications reduce the operating efficiency of an expander with newly installed blades, a higher average efficiency can be obtained over a period of time because expander performance with the thickened blades deteriorates far less rapidly than with conventionally designed blades. Hard facing in critical blade areas also helped to reduce erosion rates.

A major problem in testing for the effects of particulates is the continuous provision of a representative supply of material. It is anticipated that attempts to recycle particulates in a test system will result in their degradation to the point that interpretation of test results will be difficult. It therefore seems probable that meaningful results can best be obtaincd through the continuous generacion of a fresh supply of particulates. This would infer the need for a gasifier section to provide the required flow as well as a means of waste disposal. 
Research and Development Needs

A concensus of suggestions made by the major potential vendors of hot-gas expanders includes:

1. study and improvement of materials for high-temperature expander components (especially blades),

2. further development and testing of proprietary and patented methods for reducing damage to expander components by entrained particulates, and

3. the provision of test facilities that can provide a continuous supply of representative particulates over a lengthy test perfod.

Additional data will be required before any of the manufacturers can formulate a realistic R\&D program. This need is discussed in Sect. 5.4. 


\section{ANALYSIS AND DISCUSSION}

In the preceding section, information received from the manufacturers was presented; this section presents the evaluation of that data. Arrangement of the presentation is the same as in the preceding section, with availability, problem areas and proposed solutions, and research and development needs being discussed in that order. Emphasis is on those applications for which equipment is not available or for which availability is questionable. Proposed solutions are also emphasized, and research and development needs are evaluated.

\subsection{Pumps}

Information received in response to the pump questionnaire and in follow-up discussions with manufacturers reveals that pumps are likely to be available for all clean-liquid applications specified.; On the other hand, the availability of slurry pumps is much less clear, with erosion being the dominant problem.

\section{Availability}

The availability of equipment for each pump application in the questionnaire is summarized in Tables 11 through 15. For applications having readily available equipment, complete or nearly complete sets of data were used in compiling these summaries. Such sets of data are available for most clean-liquid applications. One entry is made for each type of pump currently available at capacities as large as or larger than that specified in lle questlunnalre. In the case of those applications for which the availability of equipment is questionable, as with most slurry pumps, poor agreement was found in the data collected. In such cases, several entries may be made to show the various levels of equipment availability along with opposing views as to the type of equipment proposed and its expected performance. In these situations, entries are sometimes made for equipment with capacitles such that multiple units will be required to meet the specified capacities. 
Teble 11. Avallability of pimps for low-pressure, low-head applications

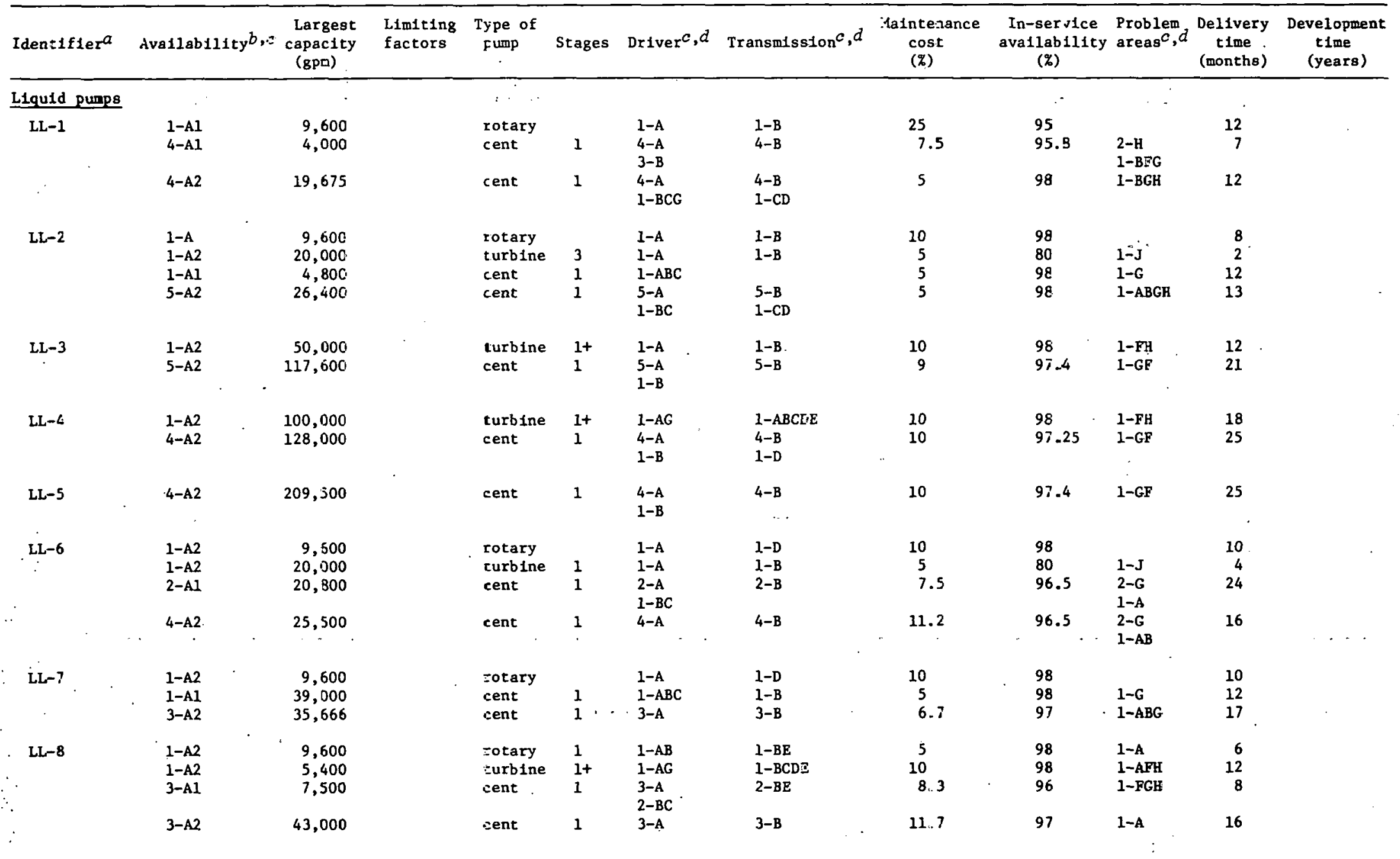


Table 11 (continued)

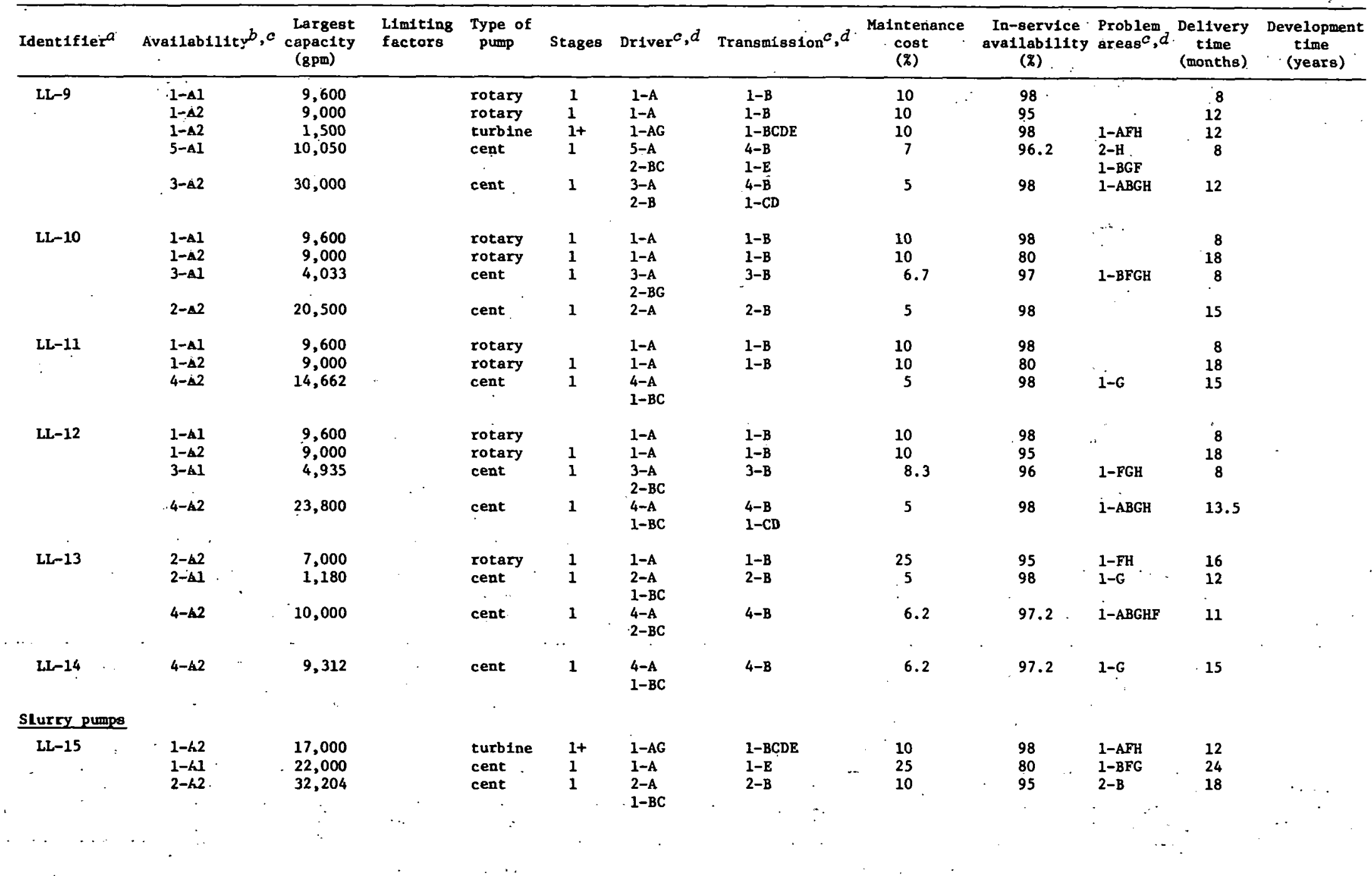


Table 11 (continued)

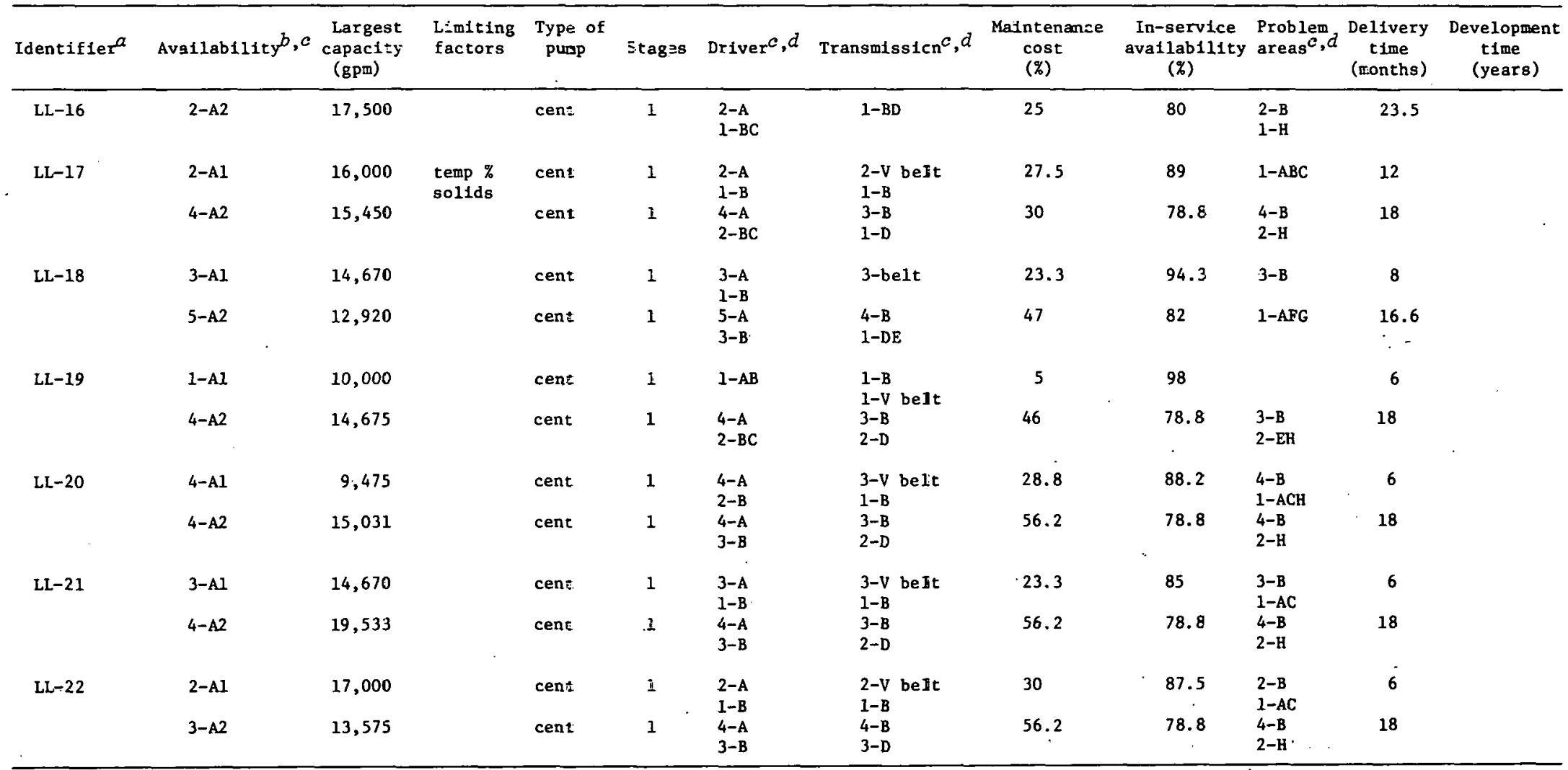

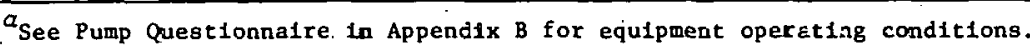

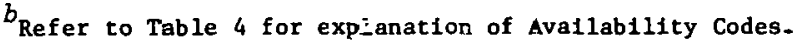

$c_{A}$ number followed by a dash before a code indicates the number of manufacturers listing that code.

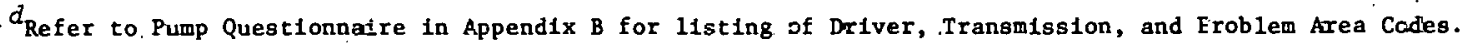


Table 12. Avallability of pumps for medium-pressure, low-head applications

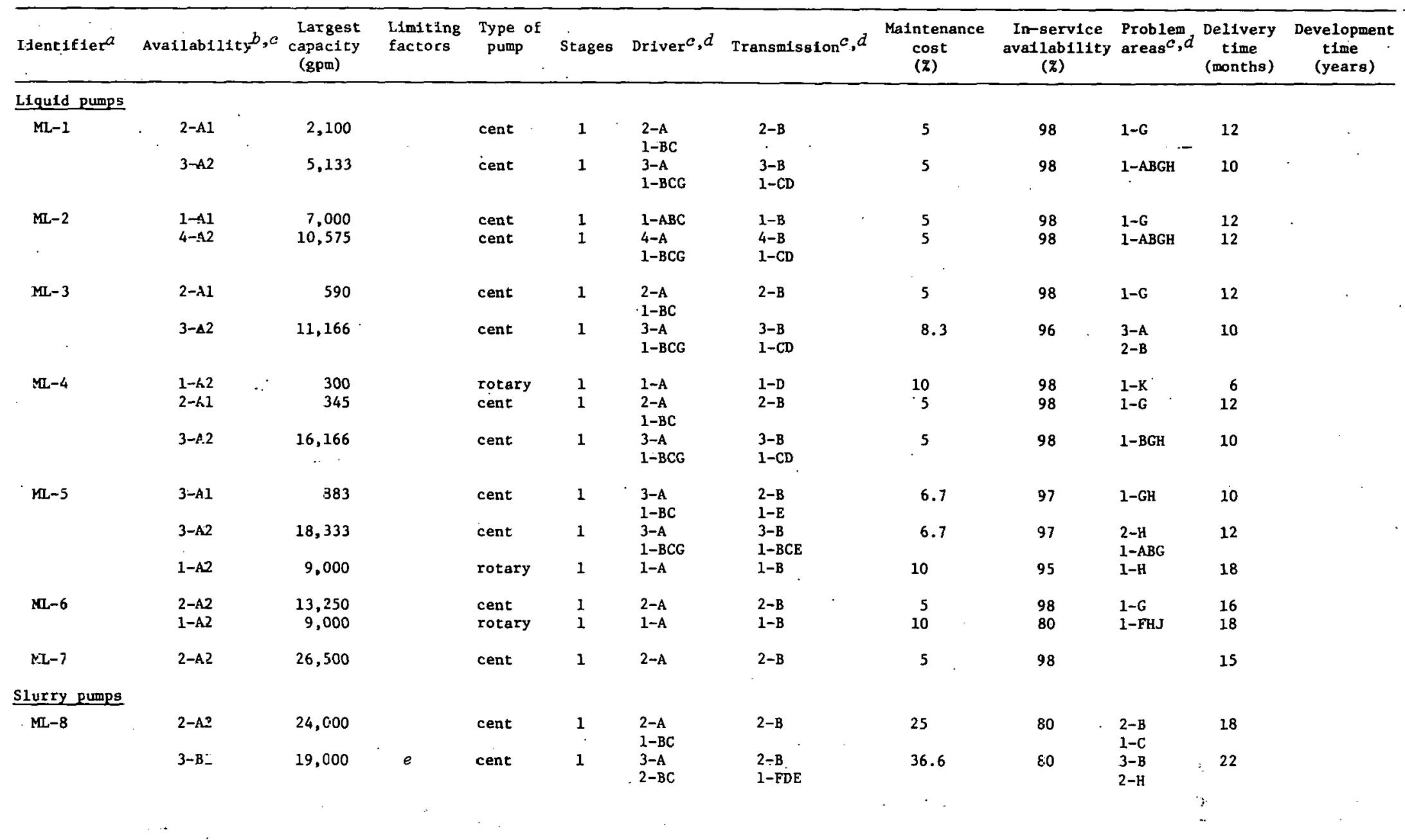


Table 12 (continued)

\begin{tabular}{|c|c|c|c|c|c|c|c|c|c|c|c|c|}
\hline Identifier ${ }^{a}$ & Ave1lability ${ }^{b, c}$ & $\begin{array}{c}\text { Eargest } \\
\text { capac1ty } \\
\text { (gpm) }\end{array}$ & $\begin{array}{l}\text { Limiting } \\
\text { factors }\end{array}$ & $\begin{array}{l}\text { Type of } \\
\text { pump }\end{array}$ & Stages & Driver $^{c, d}$ & Transmissio: ${ }^{c, d}$ & $\begin{array}{c}\text { Ma } \leq \text { ntenance } \\
\text { cost } \\
\text { (\%) }\end{array}$ & $\begin{array}{c}\text { In-service } \\
\text { avaflability } \\
(\%)\end{array}$ & $\begin{array}{l}\text { Problem } \\
\text { areas }^{c}, d\end{array}$ & $\begin{array}{l}\text { Delivery } \\
\text { time } \\
\text { (months) }\end{array}$ & $\begin{array}{c}\text { Developnent } \\
\text { time } \\
\text { (years) }\end{array}$ \\
\hline ML-9 & $\begin{array}{l}1-A 2 \\
2-B 1\end{array}$ & $\begin{array}{l}26,000 \\
21,000\end{array}$ & & $\begin{array}{l}\text { cent } \\
\text { cent }\end{array}$ & $\begin{array}{l}1 \\
1\end{array}$ & $\begin{array}{l}1-A \\
2-A \\
1-B C\end{array}$ & $\begin{array}{l}1-B \\
1-D E\end{array}$ & $\begin{array}{l}25 \\
37.5\end{array}$ & $\begin{array}{l}80 \\
80\end{array}$ & $\begin{array}{l}1-\mathrm{B} \\
2-\mathrm{B} \\
1-\mathrm{ACH}\end{array}$ & $\begin{array}{l}24 \\
15\end{array}$ & 0.5 \\
\hline$M L-10$ & $\begin{array}{l}1-A 2 \\
1-B 1 \\
1-B 1 \\
1-B 1\end{array}$ & $\begin{array}{r}6,000 \\
20,000 \\
22,000\end{array}$ & $\begin{array}{c}\text { new } \\
g\end{array}$ & $\begin{array}{l}\text { cent } \\
\text { cent } \\
\text { cent } \\
\text { cent }\end{array}$ & $\begin{array}{l}1 \\
2 \\
1 \\
h\end{array}$ & $\begin{array}{l}1-A B C \\
1-A \\
1-A B C \\
1-A\end{array}$ & $\begin{array}{l}1-B \\
1-B \\
1-D \\
1-V \text { belt }\end{array}$ & $\begin{array}{l}25 \\
50 \\
25 \\
50\end{array}$ & $\begin{array}{l}80 \\
60 f \\
80 \\
80\end{array}$ & $\begin{array}{l}\text { al1 } \\
1-B \\
1-B H \\
1-A B C\end{array}$ & $\begin{array}{l}12 \\
24 \\
12 \\
18\end{array}$ & $\begin{array}{l}1 \\
1\end{array}$ \\
\hline
\end{tabular}

${ }^{a}$ See Pump Questionnalre i:- Appendix B for equipment operating conditions.

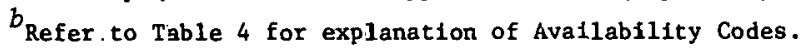

${ }^{c}$ A number followed by a dash before a code' indicates the number of manufacturers listing that code.

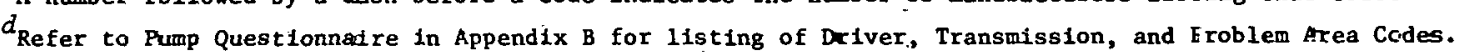

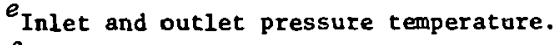

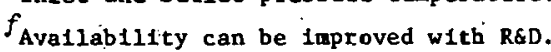

$g$ Inlet pressure and head.

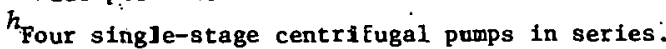


Table 13. Availability of pumps for medium-pressure, medium-head applications

\begin{tabular}{|c|c|c|c|c|c|c|c|c|c|c|c|c|}
\hline Identifter ${ }^{a}$ & Ava1 lability $y^{b, c}$ & $\begin{array}{l}\text { Largest } \\
\text { capacity } \\
\text { (gpm) }\end{array}$ & $\begin{array}{l}\text { Limicing } \\
\text { factors }\end{array}$ & $\begin{array}{l}\text { Type of } \\
\text { pump }\end{array}$ & Stages & Driver $^{c}, d$ & Transmission $c, d$ & $\begin{array}{l}\text { Maintenance } \\
\text { cost } \\
(\%)\end{array}$ & $\begin{array}{c}\text { In-service } \\
\text { ava1labillty } \\
(\bar{x})\end{array}$ & $\begin{array}{l}\text { Problem } \\
\text { areas }^{c}, d\end{array}$ & $\begin{array}{l}\text { Delivery } \\
\text { time } \\
\text { (months) }\end{array}$ & $\begin{array}{l}\text { Development } \\
\text { time } \\
\text { (years) }\end{array}$ \\
\hline \multicolumn{13}{|l|}{ Ilquic pumps } \\
\hline MM-1 & $\begin{array}{l}1-\mathrm{Al} \\
3-\mathrm{A} 2\end{array}$ & $\begin{array}{r}7,200 \\
11,166\end{array}$ & & $\begin{array}{l}\text { cent } \\
\text { cent }\end{array}$ & $\begin{array}{l}2 \\
1\end{array}$ & $\begin{array}{l}1-\mathrm{A} \\
3-\mathrm{A}\end{array}$ & $\begin{array}{l}1-B \\
3-B\end{array}$ & $\begin{array}{l}5 \\
5\end{array}$ & $\begin{array}{l}98 \\
98\end{array}$ & $1-G$ & $\begin{array}{l}12 \\
18\end{array}$ & \\
\hline$M M-2$ & $\begin{array}{l}1-\mathrm{Al} \\
3-\mathrm{A} 2\end{array}$ & $\begin{array}{r}5,400 \\
10,833\end{array}$ & & $\begin{array}{l}\text { cent } \\
\text { cent }\end{array}$ & $\underset{1-2}{2}$ & $\begin{array}{l}1-A B C \\
3-A \\
1-G\end{array}$ & $\begin{array}{l}1-B \\
3-B \\
1-C D E\end{array}$ & $\begin{array}{l}5 \\
5\end{array}$ & $\begin{array}{l}98 \\
98\end{array}$ & $1-G$ & $\begin{array}{l}12 \\
18\end{array}$ & \\
\hline & $\begin{array}{l}1-\mathrm{A} 2 \\
1-\mathrm{A} 2 .\end{array}$ & $\begin{array}{l}4,500 \\
3,700\end{array}$ & valving & $\begin{array}{l}\text { turbine } \\
\text { plunger }\end{array}$ & $\begin{array}{c}\operatorname{mult} 1 \\
e\end{array}$ & $\begin{array}{l}\text { 1-AG } \\
\text { to suit }\end{array}$ & $\begin{array}{l}1-B C D E \\
\text { to suit }\end{array}$ & $\begin{array}{l}10 \\
10\end{array}$ & $\begin{array}{l}98 \\
95\end{array}$ & $\stackrel{1-F H}{f}$ & $\begin{array}{l}18 \\
12\end{array}$ & \\
\hline$M-3$ & $\begin{array}{l}1-\mathrm{A} 2 \\
4-\mathrm{A} 2\end{array}$ & $\begin{array}{r}9,000 \\
11,325\end{array}$ & & $\begin{array}{l}\text { turbine } \\
\text { cent }\end{array}$ & $\begin{array}{c}\text { multi } \\
1-2\end{array}$ & $\begin{array}{l}1-A G \\
4-A \\
1-B C\end{array}$ & $\begin{array}{l}1-B C D E \\
4-B\end{array}$ & $\begin{array}{r}10 \\
5\end{array}$ & $\begin{array}{l}98 \\
98\end{array}$ & $\begin{array}{l}1-F H \\
1-G\end{array}$ & $\begin{array}{l}18 \\
17\end{array}$ & . \\
\hline$M-4$ & $\begin{array}{l}1-\mathrm{A} 2 \\
1-\mathrm{A} 1 \\
4-\mathrm{A} 2 \\
1-\mathrm{A} 2\end{array}$ & $\begin{array}{r}1,300 \\
1,560 \\
14,615 \\
\quad 3,700\end{array}$ & & $\begin{array}{l}\text { turbine } \\
\text { cent } \\
\text { cent } \\
\text { plunger }\end{array}$ & $\begin{array}{c}1+ \\
3 \\
1-2\end{array}$ & $\begin{array}{l}1-A G \\
1-A B C \\
3-A \\
1-B C G \\
\text { to sult }\end{array}$ & $\begin{array}{l}1-B C D E \\
1-B \\
4-B \\
1-C D \\
\text { to suit }\end{array}$ & $\begin{array}{c}10 \\
5 \\
6.2 \\
10\end{array}$ & $\begin{array}{l}98 \\
98 \\
96.5 \\
95\end{array}$ & $\begin{array}{l}1-A F H \\
2-A B G \\
1-H \\
f\end{array}$ & $\begin{array}{l}18 \\
12 \\
14\end{array}$ & - \\
\hline M-5 & $\begin{array}{l}1-\mathrm{Al} \\
3-\mathrm{A} 2\end{array}$ & $\begin{array}{r}9,600 \\
13,467\end{array}$ & . & $\begin{array}{l}\text { cent } \\
\text { cent }\end{array}$ & $\begin{array}{c}1 \\
1-2\end{array}$ & $\begin{array}{l}1-\mathrm{ABC} \\
3-\mathrm{A}\end{array}$ & $\begin{array}{l}1-B \\
3-B\end{array}$ & $\begin{array}{l}5 \\
8.3\end{array}$ & $\begin{array}{l}98 \\
96\end{array}$ & $\begin{array}{l}1-G \\
2-A \\
2-G\end{array}$ & $\begin{array}{l}12 \\
18\end{array}$ & . \\
\hline$M-6$ & 3-A2 & 17,000 & & cent & $1-10$ & $3-A$ & $3-B$ & 8.3 & 96 & $\begin{array}{l}2-A G \\
1-B H\end{array}$ & 18 & \\
\hline MM-7 & $\begin{array}{l}3-A^{2} \\
2-A^{2}\end{array}$ & $\begin{array}{r}12.333 \\
9,300\end{array}$ & & $\begin{array}{l}\text { cent } \\
\text { rotary }\end{array}$ & 1 & $\begin{array}{l}3-A \\
2-A\end{array}$ & $\begin{array}{l}3-B \\
2-B\end{array}$ & $\begin{array}{r}5 \\
25\end{array}$ & $\begin{array}{l}98 \\
80\end{array}$ & $\begin{array}{l}\text { 2-D } \\
1-F G H J\end{array}$ & $\begin{array}{l}18 \\
13\end{array}$ & \\
\hline
\end{tabular}


Table 13 (continued)

\begin{tabular}{|c|c|c|c|c|c|c|c|c|c|c|c|c|}
\hline Identifler ${ }^{a}$ & Ava1lability ${ }^{b}, c$ & $\begin{array}{l}\text { Largest } \\
\text { :apacity } \\
(\mathrm{gpm})\end{array}$ & $\begin{array}{l}\text { Limiting } \\
\text { factorg }\end{array}$ & $\begin{array}{l}\text { Type of } \\
\text { pucp }\end{array}$ & Etages & Driver ${ }^{c}, d$ & Transmission $c, d$ & $\begin{array}{l}\text { Ma intena:nce } \\
\text { cost } \\
(\%)\end{array}$ & $\begin{array}{c}\text { In-servi ze } \\
\text { availab1lity } \\
(\Phi)\end{array}$ & $\begin{array}{l}\text { Problem } \\
\text { areas }^{c}, \vec{a}\end{array}$ & $\begin{array}{l}\text { Delivery } \\
\text { time } \\
\text { (months) }\end{array}$ & $\begin{array}{c}\text { Development } \\
\text { time } \\
\text { (years }\end{array}$ \\
\hline \multicolumn{13}{|l|}{ Slurry pump } \\
\hline
\end{tabular}

${ }^{a}$ See Pump Questionnalre in Appendix B for equipmeat operating conditions.

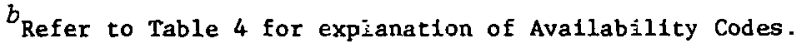

$c_{A}$ number followed by a dash before a code indicases the number of manufacturers listing that code.

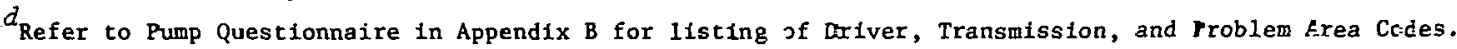

$e_{\text {Requires multiple units in paraliel. }}$

$f_{\text {Plunger, valving, and pecking. }}$

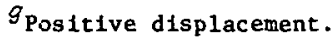

$h_{\text {Bag diaphragm. }}$

Ball check valves. 
Table 14. Avallabllity of pumps for h1gh-pressure, low-head applications

\begin{tabular}{|c|c|c|c|c|c|c|c|c|c|c|c|c|}
\hline Identifier ${ }^{a}$ & Avallaj1l1tye,c & $\begin{array}{l}\text { Largest } \\
\text { capac1ty } \\
\text { (gpm) }\end{array}$ & $\begin{array}{l}\text { Lintting } \\
\text { factors }\end{array}$ & $\begin{array}{l}\text { Type of } \\
\text { pump }\end{array}$ & Stages & Driver ${ }^{c, d}$ & Transmission $c, d$ & $\begin{array}{l}\text { Malntenance } \\
\text { cost } \\
(\%)\end{array}$ & $\begin{array}{c}\text { In-service } \\
\text { avaflab1l1ty } \\
(\%)\end{array}$ & $\begin{array}{l}\text { Problem } \\
\text { areas } c, d\end{array}$ & $\begin{array}{l}\text { Delivery } \\
\text { time } \\
\text { (months) }\end{array}$ & $\begin{array}{l}\text { Development } \\
\text { time } \\
\text { (years) }\end{array}$ \\
\hline \multicolumn{13}{|l|}{ Llquid pumps } \\
\hline BL-2 & $\begin{array}{l}1-A 1 \\
3-\Delta 2\end{array}$ & $\begin{array}{r}9,600 \\
10,670\end{array}$ & & $\begin{array}{l}\text { cent } \\
\text { cent }\end{array}$ & $\begin{array}{l}1 \\
1\end{array}$ & $\begin{array}{l}1-\mathrm{ABC} \\
3-\mathrm{A}\end{array}$ & $\begin{array}{l}1-B \\
3-B\end{array}$ & $\begin{array}{l}5 \\
6.7\end{array}$ & $\begin{array}{l}98 \\
97\end{array}$ & $\begin{array}{l}1-G \\
1-F G\end{array}$ & $\begin{array}{l}12 \\
15\end{array}$ & \\
\hline \multicolumn{13}{|l|}{ S1urry pumps } \\
\hline $\mathrm{IL}-3$ & $\begin{array}{l}2-\hbar 2 \\
1-B 1\end{array}$ & $\begin{array}{l}13,950 \\
12,000\end{array}$ & & $\begin{array}{l}\text { cent } \\
\text { cent }\end{array}$ & $\begin{array}{l}1 \\
1\end{array}$ & $\begin{array}{l}2-\mathrm{A} \\
1-\mathrm{A}\end{array}$ & $\begin{array}{l}2-B \\
1-B\end{array}$ & $\begin{array}{l}17.5 \\
25\end{array}$ & $\begin{array}{l}87.5 \\
80\end{array}$ & $\begin{array}{l}\text { 2-ABG } \\
1-\mathrm{BFGH}\end{array}$ & $\begin{array}{l}18 \\
15\end{array}$ & 0.5 \\
\hline
\end{tabular}

${ }^{a}$ See Pump Questionnaire in Appendix B for zquipment operating conditions.

$b_{\text {Refer to Table }} 4$ for explanation of Avallability Codes.

$e_{A}$ number followed by a dash jefore a code indicates the number of manufacturers listing that code.

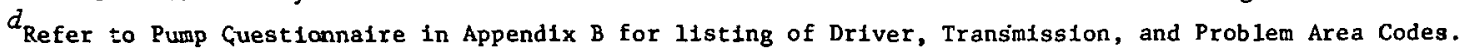


Table 15. Ava1lab1lity of pumps for high-pressure, higin-head aprlications

\begin{tabular}{|c|c|c|c|c|c|c|c|c|c|c|c|c|}
\hline Identifiera & Aqa1lability $b, c$ & $\begin{array}{l}\text { Largest } \\
\text { capacIty } \\
\text { (gpm) }\end{array}$ & $\begin{array}{l}\text { Limiting } \\
\text { factors }\end{array}$ & $\begin{array}{l}\text { Type of } \\
\text { pump }\end{array}$ & Stages & Driver $c, d$ & Transmiss $1>n^{c}, d$ & $\begin{array}{l}\text { Maintenance } \\
\text { cost } \\
\text { (I) }\end{array}$ & $\begin{array}{c}\text { In-service } \\
\text { availab111ty } \\
(\%)\end{array}$ & $\begin{array}{l}\text { Problem } \\
\text { areas } c, d\end{array}$ & $\begin{array}{c}\text { Delivery } \\
\text { time } \\
\text { (months) }\end{array}$ & $\begin{array}{c}\text { Development } \\
\text { t1me } \\
\text { (years) }\end{array}$ \\
\hline \multicolumn{13}{|l|}{ L1quid pumps } \\
\hline HH-1 & $\begin{array}{l}3-\mathrm{A}^{2} \\
1-\mathrm{A}^{2}\end{array}$ & $\begin{array}{r}11,3=3 \\
3,700\end{array}$ & & $\begin{array}{l}\text { cent } \\
\text { plunger }\end{array}$ & $2-4$ & $\begin{array}{l}\text { I-A } \\
\text { to suitt }\end{array}$ & $\begin{array}{l}\text { 1-B } \\
\text { to suit: }\end{array}$ & $\begin{array}{l}6.7 \\
10\end{array}$ & $\begin{array}{l}97 \\
95\end{array}$ & $\stackrel{1-\mathrm{GH}}{e}$ & 19 & \\
\hline HH-2 & $3-A^{2}$ & 10,555 & & cert & $2-4$ & $1-A$ & $1-B$ & 6.7 & 97 & $1-\mathrm{GH}$ & 19 & \\
\hline $\mathrm{HHB}-3$ & $\begin{array}{l}1-\mathrm{A} 1 \\
2-\mathrm{A} 2\end{array}$ & $\begin{array}{l}18,700 \\
19,000\end{array}$ & & $\begin{array}{l}\text { cer.t } \\
\text { cer.t }\end{array}$ & $\begin{array}{l}2 \\
2-3\end{array}$ & $\begin{array}{l}1-A B C \\
2-A \\
1-B\end{array}$ & $\begin{array}{l}1-B \\
2-B \\
1-C\end{array}$ & $\begin{array}{l}5 \\
7.5\end{array}$ & $\begin{array}{l}98 \\
96.5\end{array}$ & $\begin{array}{l}1-G \\
1-G H\end{array}$ & $\begin{array}{l}12 \\
17\end{array}$ & \\
\hline HH-4 & $\begin{array}{l}1-\mathrm{A} 2 \\
1-\mathrm{B} 1^{h}\end{array}$ & $\begin{array}{r}1,026 \\
36,000\end{array}$ & capacity & $\underset{\text { cent }}{f}$ & $3^{g}$ & $\begin{array}{l}1-\mathrm{A} \\
1-\mathrm{A}\end{array}$ & $\begin{array}{l}1-D \\
1-B\end{array}$ & $\begin{array}{r}5 \\
10\end{array}$ & $\begin{array}{l}80 \\
95\end{array}$ & $\begin{array}{l}1-G \\
1-G H\end{array}$ & $\begin{array}{l}12 \\
15\end{array}$ & $\begin{array}{l}0.5 \\
0.5\end{array}$ \\
\hline \multirow[t]{2}{*}{ нН-5 } & $\begin{array}{l}1-\mathrm{AI} \\
3-\mathrm{A} 2\end{array}$ & $\begin{array}{r}4,100 \\
12,700\end{array}$ & & $\begin{array}{l}\text { cent } \\
\text { cent }\end{array}$ & $2-4$ & $\begin{array}{l}1-\mathrm{ABC} \\
3-\mathrm{A}\end{array}$ & $\begin{array}{l}1-B \\
3-B\end{array}$ & $\begin{array}{c}5 \\
13.3\end{array}$ & $\begin{array}{l}98 \\
96\end{array}$ & $\begin{array}{l}1-G \\
2-A G \\
1-G H\end{array}$ & $\begin{array}{l}12 \\
19\end{array}$ & \\
\hline & $1-\mathrm{A}^{2}$ & 3,700 & & reetp & & to suit & to suit & 10 & 95 & $e$ & & \\
\hline \multirow[t]{2}{*}{ HH-6 } & $2-A_{2}$ & 15,650 & & cent & 1 & $\begin{array}{l}2-B \\
1-A C\end{array}$ & 2-B & 5 & 98 & $1-G$ & 18 & \\
\hline & 1-A2 & 32,030 & & cent & 2 & $1-\mathrm{A}$ & 1-B & 25 & 95 & $1-A G H$ & 15 & \\
\hline \multirow[t]{2}{*}{ вн-7 } & $3-A^{2}$ & 11,333 & & cent & $3-9$ & $\begin{array}{l}2-A \\
1-B\end{array}$ & $\begin{array}{l}2-B \\
I-G\end{array}$ & 8.5 & 96 & $\begin{array}{l}2-A G \\
\text { l-BH }\end{array}$ & 25 & \\
\hline & $1-\mathrm{A} 2$ & 3,730 & valving & plunger & $g$ & to suit & to suit & 10 & 95 & $e$ & 12 & \\
\hline HН-8 & 3-A2 & 10,667 & & cent & $6-10$ & $\begin{array}{l}2-A \\
1-B\end{array}$ & $\begin{array}{l}2-B \\
2-C\end{array}$ & 6.3 & 97 & $1-k$ & 25 & \\
\hline
\end{tabular}


Table 15 (continued)

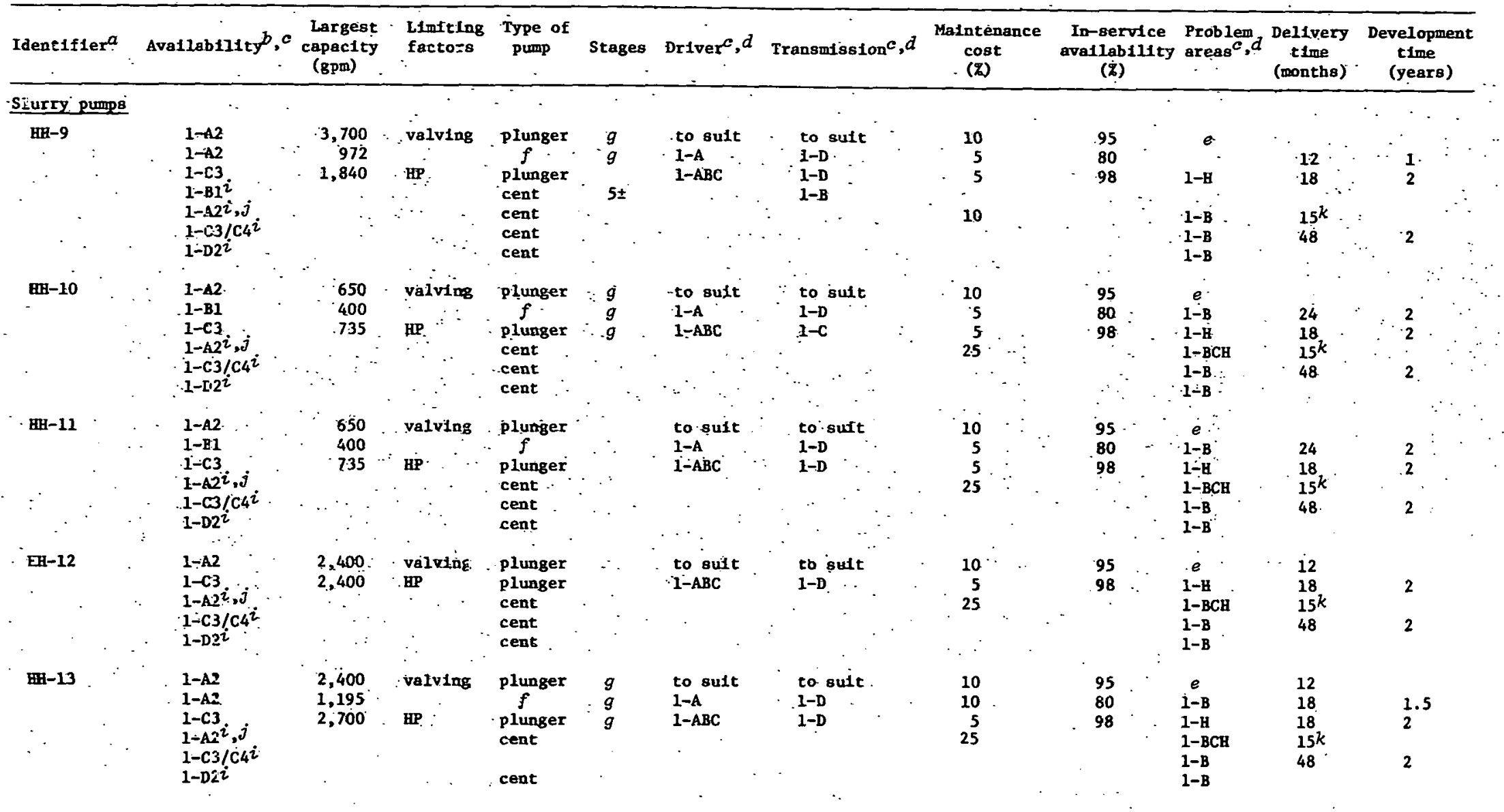


Table 15 (continued)

\begin{tabular}{|c|c|c|c|c|c|c|c|c|c|c|c|c|}
\hline Identifler ${ }^{a}$ & Availability $y^{b, c}$ & $\begin{array}{l}\text { Largest } \\
\text { capacity } \\
\text { (gpm) }\end{array}$ & $\begin{array}{l}\text { Limiting } \\
\text { factors }\end{array}$ & $\begin{array}{l}\text { Type of } \\
\text { pump }\end{array}$ & Stages & Driver ${ }^{c}, d$ & Transmisston ${ }^{c}, d$ & $\begin{array}{l}\text { Mainterance } \\
\text { cost } \\
(\%)\end{array}$ & $\begin{array}{l}\text { Ia-service } \\
\text { ava1lat-11ity } \\
\text { (\%) }\end{array}$ & $\begin{array}{l}\text { Problem } \\
\text { areas }{ }^{c}, d\end{array}$ & $\begin{array}{l}\text { Delivery } \\
\text { time } \\
\text { (months) }\end{array}$ & $\begin{array}{c}\text { Development } \\
\text { time } \\
\text { (years) }\end{array}$ \\
\hline HH-I4 & $\begin{array}{l}1-\mathrm{A} 2 \\
1-\mathrm{A} 2 \\
1-\mathrm{C} 3 \\
1-\mathrm{A} 2^{i}, j \\
1-\mathrm{C} 3 / \mathrm{C} 4^{i} \\
1-\mathrm{D} 2^{2}\end{array}$ & $\begin{array}{l}2,400 \\
1,195 \\
2,400\end{array}$ & $\begin{array}{l}\text { valving } \\
\text { HP }\end{array}$ & $\begin{array}{l}\text { plunger } \\
\vdots \\
\text { plinger } \\
\text { cent }\end{array}$ & $\begin{array}{l}g \\
g \\
g\end{array}$ & $\begin{array}{l}\text { to suit } \\
1-A \\
1-A B C\end{array}$ & $\begin{array}{l}\text { to suit } \\
1-D \\
1-D\end{array}$ & $\begin{array}{r}10 \\
10 \\
5 \\
25\end{array}$ & $\begin{array}{l}95 \\
80 \\
98\end{array}$ & $\begin{array}{l}e \\
1-B \\
1-H \\
1-B C H \\
1-B \\
1-B\end{array}$ & $\begin{array}{l}12 \\
18 \\
18 \\
15^{k} \\
48\end{array}$ & $\begin{array}{l}1.5 \\
2 \\
2\end{array}$ \\
\hline
\end{tabular}

${ }^{a}$ See Pump Questionnalie in Appendix B for equipment operating conditions.

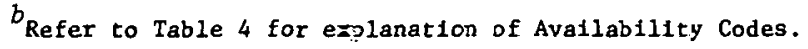

${ }^{c}$ A number followed by a Jash before a code indicates the number of manufacturers 1isting that code.

Refer to Pump Questionnalre in Appendix B for listing of Driver, Transmission, and Problem Area Dodes.

eplungers, valving, and packing.

$f_{\text {Positive displacement. }}$

$g_{\text {Requires multiple unit3. in parallel. }}$.

rothree other manufacturers stated B1 for avallatility and that development would be easy bu= provided no cather lata.

$i$ Data recelved from manufacturers of pumps for EH liquid pump applications.

${ }^{j}$ Follow-u? discussions Indicated A2 was overly sptimistic.

$k_{\text {Greater than }} 15$ months. 
Pumps are available from a number of manufacturers for each cleanliquid application specified in the pump questionnaire and would therefore also be available for all clean-liquid applications found in coal conversion facilities. Furthermore, in-house scale-up information is available to additional manufacturers for most of the clean-liquid applications. Few limiting factors of significance were listed for this equipment; when they were, they appeared to be from vendors who were commenting on pumps outside of their normal line of experience or interest. Thus pumps for clean-liquid applications are readily available and may be expected to perform according to the parameters in the summary tables.

The avallabllity of slurry pumps, however, is questionable at best. Maintenance requirements are great, and slurry pumps generally have a reputation of unsatisfactory service.

Reciprocating pumps, which are very large and must often be installed in multiple units to meet capacity requirements, have been used satisfactorily for slurries; furthermore, additional capacity is required because frequent maintenance is necessary. High slurry concentrations can be handled by reciprocating machines, pump efficiency is good, and excellent system reliability can be attained with multiple units.

Centrifugal pumps are smaller and are of ten considered to be more advanced machines than reciprocating types. They also have a reputation for being smoother running and more reliable, based on excellent experience obtained in clean-liquid service. This reputation, however, is unfounded for slurry applications. Little experience is available for use by industry in the deslyn of centrifugal slurry pumps for continuous service. Available information comes primarily from the mineral processing industry in which operation is intermittent and in which pumps are shut down for one or more shifts per week. During such time, maintenance can be performed without interrupting the process. Such frequent repairs are not desirable for the petrochemical and coal conversion industries; pumps are expected to run for several months between maintenance jobs. In general, centrifugal pumps are not available for such continuous service, based on information obtained not only from the manufacturers but also from architectengineers and users. Furthermore, if centrifugal pumps were used, spare capacity would still be required because of frequent maintenance requirements. 
Equipment for the low-pressure; low-head slurry applications (LL series*) appearing in the pump questionnalre is avallable from about two centrifugal pump manufacturers per application when consldering only manufacturers who provided complete sets of data, including maintenance cost and in-service availability. This situation provides little depth in terms of alternate supplies for this equipment, even if in-house scale-up information is available as was indlcated by several other manufacturers. Furthermore, the maintenance cost for these slurry pumps is several times that for slmilar pumps in clean-liquid service: Prnjerted. in-service availability is $\$ 80 \%$ for slurry applications in most cases vs $\sim 95 \%$ for clean-1iquid pumps. Thus pump avallability appears to be unsatisfactory for this groü of pumps in continuous service applications unless spares are furnished. Because reciprocating pumps do not match such 1ow-pressure, 1ow-head applications, extensive research and development is needed to improve the performance of centrifugal slurry pumps for this service. A program for such research and development should draw on technology avallable from both ore-handling pump and refinery pump manufacturers. . These same comments also apply to applications ML-8, ML-9, and ML-10. The data recelved for these latter applications do not mention reciprocating pump.

Fositive displacement pumps were generally specifled and appear to be satisfactory for application MM-8. The spectfled horsepower, flow rate, pressure rfse, and outlet pressure fall in ranges that match operating parameters of present-generation reclprocating pumps. The $60 \%$ solids content appears to be high for centrifugal pumps; furthermore, a 750-ps1 head requires multistage centrifugal pumps, which are not currentiy foreseen for slurry service.

The high-pressure, low-head application HL-3, which has a 10-psi pressure rise to $2500 \mathrm{psia}$, does not require the high head assuciated with reciprocating pumps. Thus currently available centrifugal pumps operated at very low speeds may, with some modifications; be suitable for this application.

\footnotetext{
* See Pump Questionnaire in Appendix B for equipment operating conditions.
} 
The high-pressure, high-head slurry pumps required for applications HH-9 through HH-14 are the least available pumps considered in this survey. Only for HH-9 is equipment currently available at the flow rate specified. In this case two full-capacity reciprocating pumps ${ }^{*}$ would be installed to provide continuous operation, although only one is needed to meet the capacity. Another option in this situation is to run both machines at. one-half of their rated speed, that is, at $50 \%$ capacity. This would extend the time between repairs and also the life of the pumps. Such a procedure is not advisable for centrifugal pumps, however, in any situation; they are designed to run near peak efficiency, and deviation from this condition will increase wear and decrease pump $11 f e$.

The other HH slurry applications require from 2 to 22 reciprocating pumps in parallel with from one to three spares. All of the information received on these reciprocating pumps, in essentially complete sets, appears in Table 15. Information received from manufacturers who have centrifugal pumps for one or more of the HH clean-liquid applications is also reported for the HH slurry applications. None of the HH slurry-pump applications can currently be satisfied with multistage centrifugal units; in fact, only one of the centrifugal pump manufacturers interviewed can foresee development of such pumps unless government funding is provided. The single company that indicated they could supply centrifugal pumps for these applications withdrew its projection during follow-up discussions. This company, which is initiating an active slurry pump development program, apparently has good in-house multistage slurry-pump technology but was overly optimiotic on the near=Lerm avallabllity of such pumps for the HH-9 through HH-14 applications.

In summary, pumps are available for all clean-liquid applications. Single-stage centrifugal equipment for low-head slurry applications (LL, ML, and HL series) requires developmental work. The medium- to high-head slurry applications ( $M M$ and $H H$ series) must be met in the near term by reciprocating machines.

\footnotetext{
* Three half-capacity units might also be used with two needed to meet capacity.
} 
$\underline{\text { Problem Areas and Proposed Solutions }}$

No problems that would substantially hinder availability and performance of pumps for clean-liquid applications were indicated. Problems that were noted are minor and may be overcome by careful specification and design of the pump based on as complete a knowledge of pump requirements as possible. For pumps in slurry applications, essentially all of the minor problems encountered with clean liquids may become significant. Furthermore, erosion becomes the dominant problem in slurry pumps.

Four basic solutions to counter erosion effects wett identified as being common to both reciprocating and centrifugal slurry pumps. These solutions include installation of spare units to maintain continuous operation, replacement of worn parts, design of machincs to run at slow speeds, and use of better construction materials. The last two solutions should reduce the erosion rate and prolong equipment life.

Repair of slurry pumps will be frequent, perhaps as often as every 3 weeks. Such frequent repair will necessitate installation of spare capacity, with the number of spare units required being dependent on the duration and frequency of repairs. Quicker maintenance turnaround can be accomplished by careful design of equipment, including easily replaceable inserts or subparts to facilitate rapid replacement of those parts subjected to the greatest erosion. In reciprocating pumps, these high-wear parts include cylinders, pistons or plungers, and, in particular, valves. Wear in centrifugal pumps is more severe than in the other pumps, affecting both impeller and casing. Sealing against back flow through worn areas, which results in decreased pump efficiency, will be difficult. The frequency of repair of both centrifugal and reciprocating slurry pumps is anticipated to be about the same; however, repalr will be more extensive for centrifugal pumps.

Slow speeds are also recommended to reduce the rate of erosion in slurry pumps. In this area, reciprocating pumps appear to have an advantage; not only have they been slower running than centrifugal machines, but their outlet pressure is dependent on valve arrangement rather than on speed. Relative velocities of no more than $100 \mathrm{fps}$ have been suggested by a number of manufacturers, and this suggestion appears 
to be a good rule of thumb; however, examples provided indicated that many pumps run more slowly. This limitation keeps pressure rise per stage to a maximum of approximately $100 \mathrm{psi}$ in centrifugal pumps; as rotational speed is decreased, the impeller diameter must be increased to maintain the desired head.

The fourth basic solution mentioned is the use of better construction materials, which would be more erosion resistant. Difficulties encountered in this approach are the availability of such materials and the limitations imposed on them. These limitations include resistance to thermal shock, pressure containment ability, and difficulty of machining. Such materials may be used for inserts or subparts in cases in which they would not be required to withstand high-pressure differentials. These inserts or subparts require only minimal machining. Surface hardening techniques that have been or are being developed should also be used when appropriate. Of the four basic solutions presented, appropriate construction materials could be the most critical to increasing pump life expectancy.

Other solutions mentioned for centrifugal pumps include better hydraulic design, provision of means for closing the gap between the wearing impeller and wear rings without opening the machine, and use of variable-speed drivers to maintain pump operation at its maximum possible efficiency regardless of the extent of wear. This last point on maintaining maximum efficiency is critical; running at lower efficiencies reduces pump life rapidly, whether a slurry or a clean liquid is handled.

The development of centrifugal slurry pumps is hindered not only by the physical limitations discussed above but also by dispersion of the necessary technology among various segments of the pump industry. The manufacturers of centrifugal pumps have tended to specialize their lines of pumps to meet the requirements of certain markets. As a result, existing slurry-pump technology is concentrated among several manufacturers who supply equipment primarily for low-pressure, low-head applications such as those found in the mineral beneficiation industry. Furthermore, existing high-pressure, high-temperature technology is found primarily among companies providing pumps to the petrochemical industries. With few exceptious, the experience gained by these various manufacturers cannot be used easily to develop multistage centrifugal slurry pumps. 
Consequently, only reciprocating pumps remain for the high-head slurry applications. These machines are limited to about 3000. to $4000 \mathrm{hp}$ per unit; thus multiple-unit installations will be required for high-flow applications. Although this requirement may be of concern to some, several multistage centrifugal slurry units in series (if they are developed) may be required to develop the high heads encountered in these applications. Furthermore, if several trains of such units were to be installed in parallel, the end result might be that as many units would be required by one type of pump as the other. In fact, unless some technological breakthrough is achieved that wlll permil development of a higher head per stage than 100 psi along with an increased acceptable life expectancy, centrifugal pumps may never be competitive in this high-pressure, high-head category.

\section{Research and Development Needs}

The current horsepower limitations of reciprocating pumps necessitates the use of multiple units in parallel to meet high-flow applications. Doubling of the current capacity of reciprocating pumps for use in firstgeneration commercial-scale liquefaction and gasification facilities is desirable. This double capacity will reduçe the number of units required for a given application and may also lead to a reductton In initial and operating costs.

Centrifugal slurry pumps of both single and multistage design are in need of development. Single-stage units need to be improved to meet the demands of continuous operation; multistage units are, at the present time, essentially nonexistent. A development target for multistage slurry pumps is the provision of an outlet pressure in the range of 600 to 800 psia, a figure seen by some manufacturers as an upper pressure limit. This target, if achieved, would bridgc the gap between existing single-stage centrifugal slurry pumps and reciprocating pumps; otherwise, the series installation of single-stage units may be required.

One of the keys to developing or improving slurry pumps, whether of centrifugal or reciprocating design, is the use of better construction materials. Research is needed in this area. 
Another key to promoting the development of centrifugal slurry-pump technology is to establish clearly market demand. The present needs of the coal conversion industry are still hazy, and many manufacturers do not wish to risk research dollars on an undetermined market. $\therefore$. Whether or not the market picture is resolved, test facilities are required. Many manufacturers do not have testing capabilities for slurries; however, several manufacturers have expressed reservations about common test facilities supported by the government because of possible disclosure requirements concerning pump design.

For the benefit of both markets, the development of pumps and hydraulic turbines to handle slurries should be coordinated.

\subsection{Compressors}

Compressors are available for most applications found. In the coal conversion Industry. There are, however, several significant exceptions: high-pressure oxygen compressors and high-flow. low-head fans and blowers, particularly for streams containing entrained particulates. This section addresses primarily these exceptional items of equipment.

\section{Ava1lability}

In addition to fan and blower and oxygen-compressor applications, the low-flow applications $\mathrm{MH}-1, \mathrm{VH}-1$, and $\mathrm{VH}-2,{ }^{*}$ for which compressors are available, are also considered below.

Fans and Blowers. As a class, the least read1ly ava1lable machines are the large fans or blowers in the "FB" classification (see Table 9). Only two companies, Elliott and American Demag, market these units in the relatively large sizes specified. For the five applications in which entrained particulates are either absent or in relatively low concentrations (indentifiers $\mathrm{FB}-1$ through $\mathrm{FB}-5$ ), both vendors offer axial flow blowers; the maximum capacity of the Elliott machines is 350,000 acfm; American Demag offers capacities up to 720,000 acfm.

\footnotetext{
* See Compressor Questionnaire in Appendix B for equipment operating cunditions.
} 
A single American Demag machine would satisfy the volumetric flow requirements for all of the applications except FB-4, in which the 800,000 -acfm réquirement exceeds the 720,000 -acfm availability by about $11 \%$; therefore, smaller machines in parallel would be required. With the Elliott 350,000 -acfm limit, two or three parallel compressors would be required for applications $\mathrm{FB}-3, \mathrm{FB}-4$, and $\mathrm{FB}-5$.

Although there were differences in the initial proposals of. the two above-mentioned vendors for the applications in which particulate-laden gases are involved, both finally recommended the use of centrifugal blowers for all applications, primarlly because centrifugal impellers can be built with impeller vanes that are relatively thicker and that have larger surface areas than axial-flow compressor blades. For these reasons, centrifugal units withstand abrasion by particulates for a longer time. Eliiott stated that volumetric flow rates of about 350,000 acfm could be produced with double-flow centrifugal machines. American Demag specified maximum flows of 200,000 acfm for single-flow centrifugals and stated in a general note that greater levels could be obtained with double-flow construction.

If it is assumed that both vendors can produce 350,000 -acfm blowers of double-flow construction, two parallel machines would be required for applications $F B-6$ and $F B-9$, and three blowers in parallel would be needed for identifier $\mathrm{FB}-7$. The 360,000 -acfm requirement for $\mathrm{FB}-8$ is on $1 \mathrm{y}$ slightly above the postulated maximum available capacity.

In an actual plant, reliability and maintenance considerations might frequently dictate the use of two or more parallel blowers or compressors. In drafting the questionnaires, it was decided that the entire flow requirement for a given application would be specified for a single machine in some cases. This would elicit information on maximum flows that could be handled by available equipment.

The relatively high $\left(700^{\circ} \mathrm{F}\right)$ inlet temperature requirements for identifiers $\mathrm{FB}-6$ and $\mathrm{FB}-7$ will require improved materials and more sophisticated design; therefore, cost and delivery times for these particular units will be increased. Furthermore, for all. cases involving particulates, the characteristics of the particle involved are important. Relatively soft particles will affect the life of a blower less 
significantly than will sharp and highly abrasive ones. On the other hand, even soft particles can cause major problems if they adhere to the rotating components because imbalance and vibration can result.

Oxygen Compressors. As mentioned in Sect. 4.2, an initial misinterpretation of the process information for ML-4, ML-5, and ML- 6 resulted in flow requirements being overstated by a factor of 32 (see Table 9); therefore, the largest volumetric flow should have been specified as about $28,000 \mathrm{acfm}$ (for ML-6). The responses to the questionnaire indicate that this capacity should be available on a normal special-order basis, using a compressor of centrifugal design. The specified discharge pressure for each of these identifiers is 270 psia.

Specifications for the $\mathrm{HH}-4$ and $\mathrm{HH}-5$ oxygen compressors are identical in all respects except for volumetric flow, which differs by a factor of two. Several vendors offer to supply these compressors on a special-order basis, with the normal 18- to 24-month delivery. The 710-psia discharge pressure specified for these machines is relatively high. Although many oxygen compressors now in service operate with discharge pressures of as high as about 600 psia, two exceptions are known to be operating at higher pressures. These compressors were designed for operation at an outlet pressure of 960 psia; reportedly one of the compressors has been operated experimentally at pressures as high as 1500 psia.

Requirements for high-pressure oxygen compressors exist for several coal conversion processes. These requirements were not clearly identified in the equipment lists of reports mentioned in Sect. 3.1 and Appendix A. One such requirement for provision of 2000 tons per day of oxygen would demand an inlet volumetric flow of about 35,000 acfm at $80^{\circ} \mathrm{F}$ and 15 psia. The required outlet pressure for the process would be about 1250 psia; the required compressor-discharge pressure might be 50 to 100 psi higher.

Low-Volumetric Flow Applications. The following cases are worthy of special mention. 


\begin{tabular}{|c|c|c|c|c|c|c|}
\hline \multirow{2}{*}{ Identifier } & \multirow{2}{*}{$\begin{array}{c}\text { Volume } \\
\text { flow } \\
\text { (acfm) }\end{array}$} & \multicolumn{2}{|c|}{$\begin{array}{c}\text { Pressures } \\
\text { (psia) }\end{array}$} & \multirow{2}{*}{$\begin{array}{c}\text { Pressure } \\
\text { ratio }\end{array}$} & \multirow{2}{*}{\multicolumn{2}{|c|}{$\begin{array}{c}\text { Gas composition } \\
(\text { mole } \%)\end{array}$}} \\
\hline & & Inlet & Outlet & & & \\
\hline ML-1 & . 400 & 18 & 470 & 26.1 & $42 \% \mathrm{H}_{2} \mathrm{O}$, & $31 \% \mathrm{H}_{2} \mathrm{~S}, 27 \% \mathrm{NH}_{3}$ \\
\hline $\mathrm{VH}-1$ & 7000 & 1055 & 4268 & 4.0 & $99 \% \mathrm{H}_{2}$ & $1 \% \mathrm{~N}_{2}$ \\
\hline $\mathrm{VH}-2$ & 2000 & 550 & 2600 & 4.7 & $96 \% \mathrm{H}_{2}$ & $4 \% \mathrm{CH}_{4}$ \\
\hline
\end{tabular}

The very low volumetric flow and high-pressure ratio of application MH-1 will definttely require the use of a reciprocating compressor accordIng to:seven of the elght vendors who furnished information for this application. A similar situation prevails for application VH-2 because of the low-flow and high-outlet pressure.

For application VH-1; two vendors estimated that from 40 to 65 centrifugal stages would be required for compression because of the thermodynamic characteristics of hydrogen. The responses for this application were evenly divided; three vendors recommended reciprocating compressors, and three others specified centrifugal machines. The ultimate selection would undoubtedly be based on an economic comparison, including costs not only for the compressors but also for the associated drive trains.

As mentioned earlier, centrifugal compressors can be built for volumetric flows as low as 500 acfm or lower. As the flow decreases, however, all dimensions of the centrifugal impeller must be reduced proportionately if excessive losses in efficiency are to be avoided. To produce a given pressure rise, however, the peripheral velocity (tip speed). of the impeller must be maintained approximately constant. As volume flow is reduced, therefore, the rotating speed of the impeller must be Increased; hence the speeds for centrifugal compressors for. applications $\mathrm{MH}-1$ and $\mathrm{VH}-2$ would be extremely high. For this reason, rectprocating compressors become more economical for low-volumetric flow applications, particularly when relatively high-outlet pressures or pressure ratios are involved:

Potential vendors of reciprocating compressors are probably underrepresented in their input to this survey. When centrifugal and reciprocating compressors are built by the same company, they are often marketed by separate divisions. Because the questionnaire contained a 
preponderance of centrifugal and axial flow applications, it was usually referred first to that division and probably arrived either late or not at all at the division that would handle reciprocating compressor inquiries. Future specific individual requests for information on low-volumetric flow compressors may be expected to receive a larger number of responses than was received in answer to this questionnaire.

Reciprocating compressors are a single species in the more general class of positive displacement compressors; several other types of positive displacement compressors are manufactured, of which rotary-lobe compressors are one example. These latter machines are widely used for a variety of applications but are not currently available for the relatively high pressures required for the low-volumetric flow cases specified in the questionnaire.

\section{Problem Areas and Proposed Solutione}

The applications expected to pose the most major problems in the successful specification of compressors are the four applications that involve particulate levels in the gas stream of 0.5 to 1.5 grains per acf (identifiers FB-6 through FB-9). As noted in the preceding section, these machines would normally be axial flow fans; however, two vendors have recommended that centrifugal blowers be used instead because their impellers are relatively thicker than the axial fan blades and thus should last longer. The maximum flow required by any of the process flow sheets (specifically, the Coalcon process) for any of these four applications is $410,000 \mathrm{acfm}$. Two 200,000 -acfm centrifugal blowers in parallel will very nearly satisfy this requirement. It is conceivable that some of the techniques for handling particulates in hot-gas expanders (see Sect. 4.4) could also be applied to these particular applications.

Eyulpment suppliers and users express different opinions about the reliability and safety of high-pressure oxygen compressors, extending even to whether it is better to pump liquid oxygen or compress gaseous oxygen to the high pressures required by some processes. Questions of overall process economics and the relative sophistication of the compressors (including components and controls) supplied by various U.S, and foreign. manufacturers are involved. 
In the past, destruction of high-pressure oxygen compressors by burning or explosion has occurred because of the high reactivity of oxygen with metals in the presence of heat. The likelihood of such accidents is reported to increase with operating pressure; however, these chances can be minimized by the following combination of measures:

1. maintaining the maximum temperature of the oxygen stream below $200^{\circ} \mathrm{C}\left(392^{\circ} \mathrm{F}\right)$,

2. restricting temperatures to even lower levels in the higher pressure sections of the compressor,

3. alopting a conservative compressor design that will ensure against contact between rotating and stationary parts,

4. practicing stringent cleanliness control during system assembly, and

5. providing reliable temperature and other special monitoring devices.

The adoption of these measures reportedly permitted the successful experimental operation of the previously mentioned oxygen compressor at pressures as high as 1500 psia.

Many important questions that affect the initial and operating costs for compressors were not addressed in this brief survey. For example, many of the medium- and high-pressure ratio compressors have a number of variables that can affect both types of costs. Intercooling between compression stages, which can significantly reduce horsepower requirements, may increase overal1 equipment cost; in some cases intercooling may be mandatory for temperature control. There are other situations in which it is most economical and practical to build a compressor having as many as nine or ten stages in a single casing, even though overall efficiency and the range of stable operation are thereby decreased. In other cases, requirements for high efficiency and a wide range of stable operation may demand the use of several separate compressors in series.

The proper matching of compressors and drivers also warrants considerable study. In many coal conversion plants, steam turbines or hot-gas expanders will be installed as compressor drives to make use of 
excess energy from the conversion process. It is often possible to tailor the speeds and other characteristics of compressors to match the preferred characteristics of the drivers and vice versa.

Past experience indicates that careful preparation of realistic compressor specifications can be a key factor in the procurement of equipment that will operate reliably and economically under actual process conditions. Such specifications should avoid restrictions often imposed by the use of existing industry codes prepared for conditions prevailing earlier; the main objective of the specifications should be to set forth the true operating conditions and other key parameters in a clear, unambiguous manner.

Research and Development Needs

One definite need is apparent, and a second one also probably exists. The first need is the development of techniques for dealing with particulate-laden gas streams in the large, low-pressure blowers or fans covered by identifiers FB-6 through FB-9. As is apparent from sects. 4.4 and 5.4 dealing with hot-gas expanders, the problems caused by particulates will be a major source of concern for these expanders; these problems will require substantial research and development programs. It seems probable that many of the development activities for blowers can be an offshoot of the expander program; furthermore, additional specialized but limited efforts may be advisable for the development of these blowers.

Further study is required to define the optimum research and development program for the second area, high-pressure oxygen compressors. It seems possible that the most important function of such a program may be to assist major U.S. manufacturers of process compressors to advance their technology in the areas of stability and vibration analysis, mechanical rigidity and iesllence of the compressor and drive train, and temperature and other fault-detection instrumentation.

This further study would include additional discussions with users of high-pressure oxygen compressors, with representatives of technologyintensive consulting and specialized compressor-manufacturing firms, and possibly with compressor manufacturers. 


\subsection{Hydraulic Turbines}

As with pumps, hydraulic turbines are available for clean-liquid applications, but availability is questionable for slurry applications.

\section{Availability}

The availability of equipment for hydraulic turbine applications is summarized in Table.16. Several sets of data are presented for each application, the first having been received from the sole hydroturbine manufacturer responding. Data recelved from centrifugal pump manufacturers, who would generally use pumps operated in reverse rotation for these applications, is then presented; data for similar equipment is averaged. Information received from a hydraulic motor manufacturer for two applications is also tabulated. Turbines developed by the hydroturbine'industry have efficiencies as high as 91 or $92 \%$ as opposed to efficiencies of approximately 80 to $85 \%$ obtained by operating pumps in reverse. Furthermore, the method for determining efficiencies in the hydroturbine industry is more demanding than the method used by pump manufacturers; therefore, results are more conservative.

Hydraulic turbines are available for the clean-liquid applications $\mathrm{T}-1$ through $\mathrm{T}-17 .^{*}$, The very low slurry concentration of applications $\mathrm{T}-18$ and T-19 is not expected to limit the avallability of equipment; however, as slurry concentrations become greater, the availability of turbines will become much more limited than is the case with pumps. The one company indicating available equipment for T-20 through T-24 and scale-up information for T-25. and T-26 later qualified these projections as being overly optimistic. As a result, no equipment is immediately available for these last seven applications, although the design of equipment for applications T-20 through $\mathrm{T}-24$ may be forthcoming if market demand is sufficient. The extremely high pressure of applications T-20 through $\mathrm{T}-22$ is also limiting because of the need for multistage turbines. Development of equipment for slurry turbines, except for extremely low slurry concentrations, may require government funding.

\footnotetext{
* See Hydraulic Turbine Questionnaire in Appendix B for equipment operating conditions.
} 
Table 16. Availabillty of equipment for hydraulic turbine applications

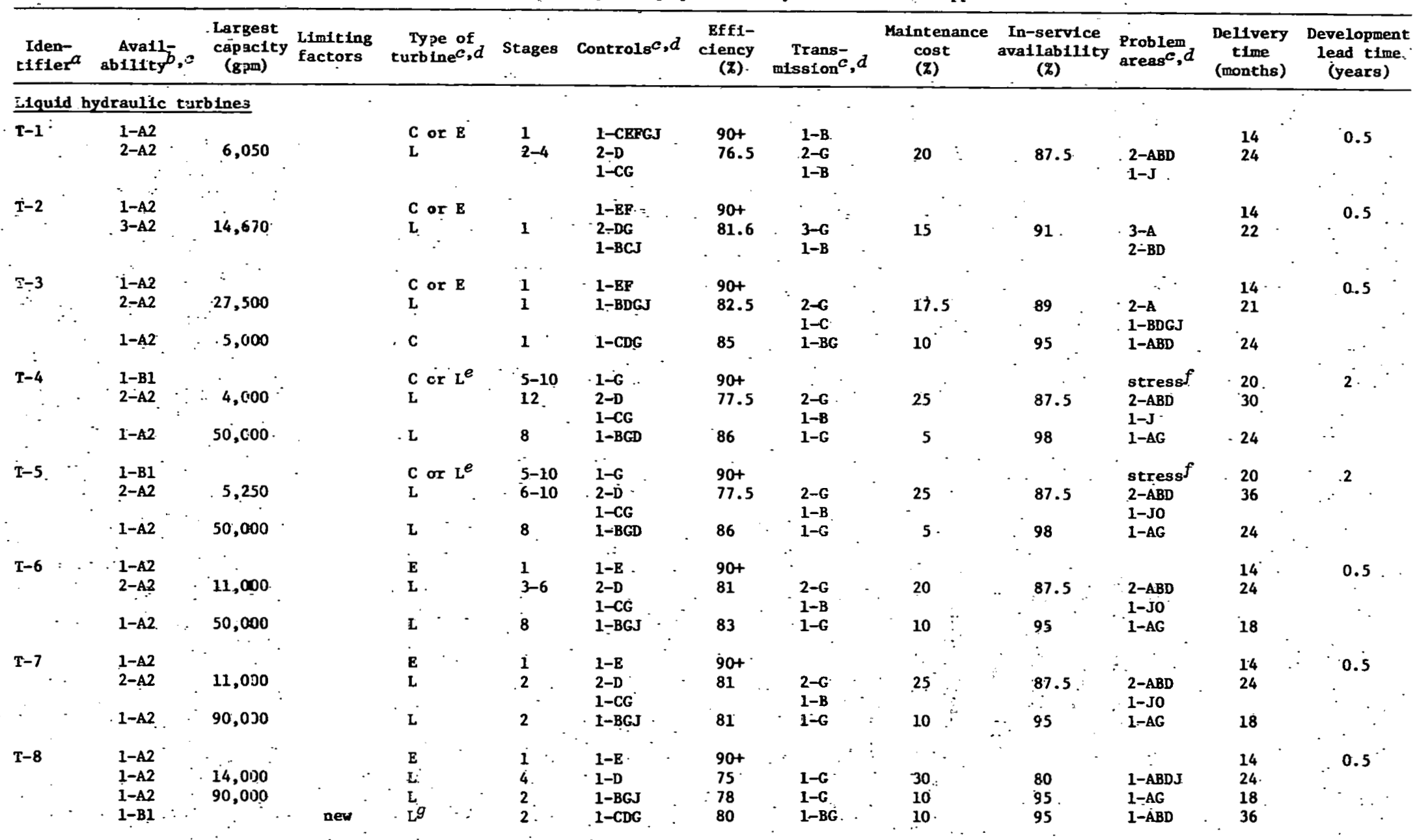


Table 16 (continued)

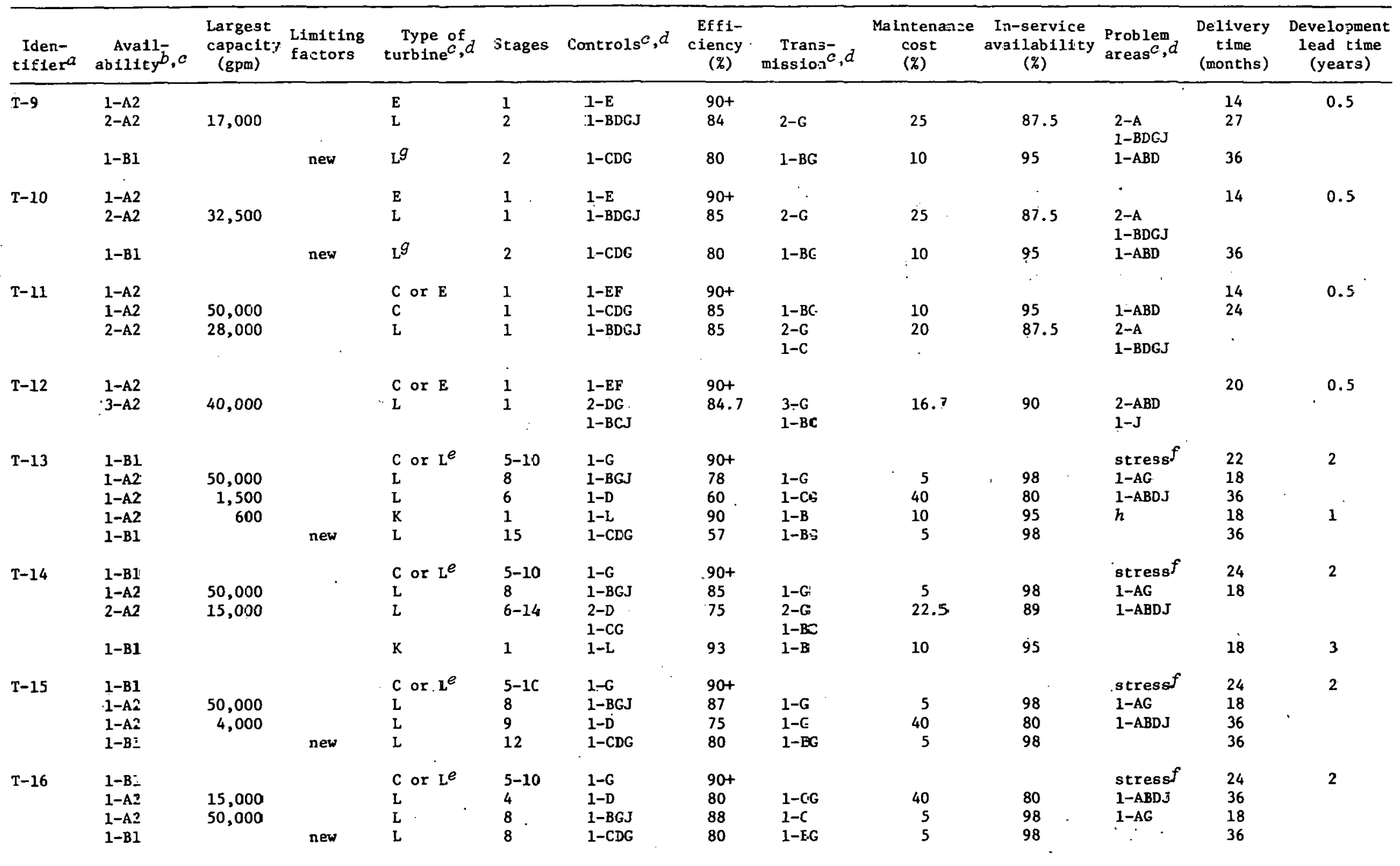


Table 16 (continued)

\begin{tabular}{|c|c|c|c|c|c|c|c|c|c|c|c|c|c|}
\hline $\begin{array}{l}\text { Iden- } \\
\text { tifier }^{a}\end{array}$ & $\begin{array}{l}\text { Avall } \\
\text { ability }, c\end{array}$ & $\begin{array}{l}\text { Largest } \\
\text { capacity } \\
\text { (gFm) }\end{array}$ & $\begin{array}{l}\text { Limiting } \\
\text { factors }\end{array}$ & $\begin{array}{l}\text { Type of } \\
\text { turbine } \\
c, d\end{array}$ & $\begin{array}{c}\text { Stages } \\
.\end{array}$ & Controls ${ }^{c}, d$ & $\begin{array}{l}\text { Effi- } \\
\text { clency } \\
(\%)\end{array}$ & $\begin{array}{l}\text { Trans- } \\
\text { mission } \\
c, d\end{array}$ & $\begin{array}{l}\text { Maintenance } \\
\text { cost } \\
(\%)\end{array}$ & $\begin{array}{c}\text { In-service } \\
\text { availability } \\
(\%)\end{array}$ & $\begin{array}{l}\text { Problem } \\
\text { areas } c, d\end{array}$ & $\begin{array}{l}\text { Delivery } \\
\text { time } \\
\text { (months) }\end{array}$ & $\begin{array}{l}\text { Development } \\
\text { lead time } \\
\text { (years) }\end{array}$ \\
\hline $\mathrm{T}-17$ & $\begin{array}{l}\mathrm{i}-\mathrm{B} 1 \\
1-\mathrm{A} 2 \\
1-\mathrm{A} 2\end{array}$ & $\begin{array}{l}50,000 \\
15,000\end{array}$ & $i$ & $\begin{array}{l}\mathrm{C} \text { or } \mathrm{L}^{e} \\
\mathrm{~L} \\
\mathrm{~L}\end{array}$ & $\begin{array}{l}5-10 \\
8 \\
4\end{array}$ & $\begin{array}{l}1-G \\
1-B G J \\
1-D\end{array}$ & $\begin{array}{l}90+ \\
88 \\
80\end{array}$ & $\begin{array}{l}1-G \\
1-C G\end{array}$ & $\begin{array}{r}5 \\
40\end{array}$ & $\begin{array}{l}98 \\
80\end{array}$ & $\begin{array}{l}\text { stress } f \\
1-A G \\
1-A B D J\end{array}$ & $\begin{array}{l}24 \\
18 \\
36\end{array}$ & 2 \\
\hline \multicolumn{14}{|c|}{ Slurry hydraulic turbines } \\
\hline$T-18$ & $\begin{array}{l}1-\mathrm{A} 2 \\
1-\mathrm{A} 2 \\
1-\mathrm{B} 1\end{array}$ & $\begin{array}{l}30,000 \\
40,000\end{array}$ & $j \quad$. & $\begin{array}{l}\text { C } \\
\text { L } \\
\text { L }\end{array}$ & $\begin{array}{l}1 \\
1 \\
1\end{array}$ & $\begin{array}{l}1-F \\
1-C D G \\
1-B G J\end{array}$ & $\begin{array}{l}90+ \\
75 \\
80\end{array}$ & $\begin{array}{l}1-B C G \\
1-G\end{array}$ & $\begin{array}{l}25 \\
10\end{array}$ & $\begin{array}{l}80 \\
95\end{array}$ & $\begin{array}{l}1-B \\
1-A G\end{array}$ & $\begin{array}{l}14 \\
24 \\
18\end{array}$ & $\begin{array}{l}0.5 \\
0.5\end{array}$ \\
\hline T-19. & $\begin{array}{l}1-\mathrm{A} 2 \\
1-\mathrm{A} 2 \\
1-\mathrm{A} 2\end{array}$ & $\begin{array}{r}20,030 \\
4,530\end{array}$ & & $\begin{array}{l}\mathbf{E} \\
\mathrm{L} \\
\mathrm{L}\end{array}$ & $\begin{array}{l}1 \\
3-4 \\
6\end{array}$ & $\begin{array}{l}1-E \\
1-B G J \\
1-C D E\end{array}$ & $\begin{array}{l}90+ \\
80 \\
80\end{array}$ & $\begin{array}{l}1-G \\
1-B G\end{array}$ & $\begin{array}{r}5 \\
25\end{array}$ & $\begin{array}{l}98 \\
80\end{array}$ & $\begin{array}{l}1-A G \\
1-B\end{array}$ & $\begin{array}{l}16 \\
18\end{array}$ & 0.5 \\
\hline $\mathrm{T}-20$ & $\begin{array}{l}1-\mathrm{B} 1 \\
1-\mathrm{A} 2^{2} \\
1-\mathrm{D} 2\end{array}$ & 20,0100 & $k$ & $\begin{array}{l}\mathrm{C} \text { or } \mathrm{L}^{e} \\
\mathrm{~L}\end{array}$ & $\begin{array}{l}5-10 \\
8\end{array}$ & $\begin{array}{l}1-G \\
1-B G J\end{array}$ & $\begin{array}{l}90+ \\
80\end{array}$ & $\begin{array}{l}1-G \\
1-B\end{array}$ & 10 & 95 & $\begin{array}{l}\text { stress } f \\
1-A B G \\
1-B\end{array}$ & $\begin{array}{c}22 \\
18 \\
\cdot \quad\end{array}$ & 2 \\
\hline T-21 & $\begin{array}{l}1-\mathrm{B} 1 \\
1-\mathrm{A} 2^{2} \\
1-\mathrm{D} 2\end{array}$ & 20,000 & $k$ & $\begin{array}{l}\mathrm{C} \text { or } \mathrm{L}^{e} \\
\mathrm{~L}\end{array}$ & $\begin{array}{l}5-10 \\
8\end{array}$ & $\begin{array}{l}1-G \\
1-B G J\end{array}$ & $\begin{array}{l}90+ \\
82\end{array}$ & $1-G$ & 10 & 95 & $\begin{array}{l}\text { stress } f \\
1-A B G \\
1-B\end{array}$ & $\begin{array}{l}24 \\
18\end{array}$ & 2 \\
\hline $\mathrm{T}-22$ & $\begin{array}{l}1-\mathrm{B} 1 \\
1-\mathrm{A} 2\end{array}$ & 20,000 & $k$ & $\begin{array}{l}\mathrm{C} \text { or } \mathrm{L}^{e} \\
\mathrm{~L}\end{array}$ & $\begin{array}{l}5-10 \\
6\end{array}$ & $\begin{array}{l}1-G \\
1-B G J\end{array}$ & 84 & $1-G$ & 10 & 95 & $\begin{array}{l}\text { stress } f \\
1-\mathrm{ABG}\end{array}$ & $\begin{array}{l}24 \\
18\end{array}$ & 2 \\
\hline $\mathrm{T}-23$ & $\begin{array}{l}1-B 1 \\
1-A 2 Z \\
1-B 1\end{array}$ & 40,000 & $\begin{array}{l}k \\
\text { new }\end{array}$ & $\begin{array}{l}\text { C or } E \\
\text { L } \\
\text { L }\end{array}$ & $\begin{array}{l}1 \\
1 \\
2\end{array}$ & $\begin{array}{l}1-E F \\
1-B G J \\
1-C D G\end{array}$ & $\begin{array}{l}80 \\
70\end{array}$ & $\begin{array}{l}1-G \\
1-B C G\end{array}$ & $\begin{array}{l}10 \\
50\end{array}$ & $\begin{array}{l}95 \\
60\end{array}$ & $\begin{array}{l}1-\mathrm{ABG} \\
1-\mathrm{B}\end{array}$ & $\begin{array}{l}14 \\
18 \\
24\end{array}$ & $\begin{array}{l}0.5 \\
1\end{array}$ \\
\hline$T-24$ & $\begin{array}{l}1-\mathrm{B} 1 \\
1-\mathrm{A} 2^{2} \\
1-\mathrm{B} 1\end{array}$ & 40,0010 & $\begin{array}{l}k \\
\text { new }\end{array}$ & $\begin{array}{l}\text { C or } \mathrm{E} \\
\mathrm{L} \\
\mathrm{L}\end{array}$ & $\begin{array}{l}1 \\
1 \\
2\end{array}$ & $\begin{array}{l}F \\
1-B G J \\
1-C D G\end{array}$ & $\begin{array}{l}84 \\
78\end{array}$ & $\begin{array}{l}1-G \\
1-B G C\end{array}$ & $\begin{array}{l}10 \\
50\end{array}$ & $\begin{array}{l}9.5 \\
60\end{array}$ & $\begin{array}{l}1-A B G \\
1-B\end{array}$ & $\begin{array}{r}.14 \\
18 \\
1\end{array}$ & 0.5 \\
\hline$T-25$ & $\begin{array}{l}1-\mathrm{C} 1 / \mathrm{C} 3 \\
1-\mathrm{B} 1 \\
1-\mathrm{D} 2\end{array}$ & 9,000 & $\begin{array}{l}k \\
\text { solftds }\end{array}$ & $\begin{array}{l}\text { E } \\
\text { L }\end{array}$ & $\begin{array}{l}1 \\
2-4\end{array}$ & $\begin{array}{l}1-E \\
1-B G J\end{array}$ & 75 & $1-6$ & 25 & 85 & $\begin{array}{l}1-A B G \\
1-B\end{array}$ & $\begin{array}{l}14 \\
18\end{array}$ & $\begin{array}{l}0.5 \\
0.5\end{array}$ \\
\hline
\end{tabular}


Cable 16 (continued)

\begin{tabular}{|c|c|c|c|c|c|c|c|c|c|c|c|c|c|}
\hline $\begin{array}{l}\text { Iden- } \\
\text { tifier }\end{array}$ & ${ }_{\text {ability }}^{\text {Avatl }}, c$ & $\begin{array}{l}\text { Largest } \\
\text { capacity } \\
\text { (gpm) }\end{array}$ & $\begin{array}{l}\text { Limiting } \\
\text { factors }\end{array}$ & $\begin{array}{l}\text { Type of } \\
\text { turbine } \\
c, d\end{array}$ & Stages & Zontrols $s^{c, d}$ & $\begin{array}{c}\text { Effi- } \\
\text { ciency } \\
(\%)\end{array}$ & $\underset{\text { mission }}{\operatorname{Tr}, d}$ & $\begin{array}{l}\text { Maintenance } \\
\text { cost } \\
(\%)\end{array}$ & $\begin{array}{c}\text { In-service } \\
\text { availatility } \\
\text { (\%) }\end{array}$ & $\begin{array}{l}\text { Problem } \\
\text { areas }^{c}, d\end{array}$ & $\begin{array}{c}\text { Delivery } \\
\text { time } \\
\text { (months) }\end{array}$ & $\begin{array}{c}\text { Development } \\
\text { lead time } \\
\text { (years) }\end{array}$ \\
\hline$T-26$ & $\begin{array}{l}1-\mathrm{C} 1 / \mathrm{C} 3 \\
1-\mathrm{B} 12 \\
1-\mathrm{D}\end{array}$ & 9,000 & $\begin{array}{l}k \\
\text { solids }\end{array}$ & $\begin{array}{l}\mathrm{E} \\
\mathrm{L}\end{array}$ & $\begin{array}{l}1 \\
2-4\end{array}$ & $\begin{array}{l}1-E \\
1-B G J\end{array}$ & 75 & $1-3$ & 25 & 85 . & $\begin{array}{l}1-A \cdot B G \\
1-B\end{array}$ & $\begin{array}{l}14 \\
18\end{array}$ & $\begin{array}{l}0.5 \\
0.5\end{array}$ \\
\hline
\end{tabular}

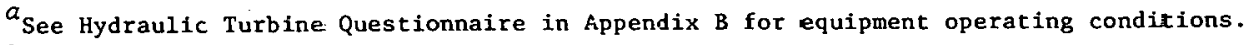

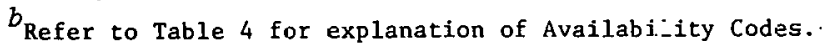

$c_{A}$ number followed by a dash before a code inficates the number of manufacturers listing that code.

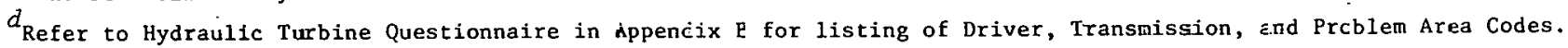

$e_{\text {Barrel pump type construction required by high pressure. }}$

$f_{\text {Stress is caused by high pressure. }}$

${ }^{g}$ Special design required to handle high dissolved gas content.

$h_{\text {Filier required. }}$

$i_{\text {High horsepower requirement. }}$

$j_{\text {High head-to-capacits ratio. }}$

$k_{\text {Life expectancy. }}$

${ }^{2}$ Avallability stated is overly optimistic based on foliow-up discussions. 
Problems and Proposed Solutions

Most of the problems in hydraulic turbine applications are analogous to those for pumps; they therefore have similar solutions. Outlet pressure must be considered in turbine design, as would inlet pressure in pump. design, as the critical parameter in avoiding cavitation problems. Erosion is likely to be more severe in turbines than in pumps if given the same slurry stream. Utilization of technology developed for slurry pumps will be beneficial to the turbine industry.

\section{$\underline{\text { Research and Development Needs }}$}

Development programs for hydraulic turbines that must handle slurries should be coordinated with slurry pump programs so as to derive maximum benefits from each project. The reasons for higher turbine efficiencies should also be determined and investigated for their applicability to pump design. Resulting design modifications might be particularly beneficial because higher efficiencies lead to less wear.

The use of hydraulic turbines as pressure letdown devices, with power recovery being a side benefit, has been suggested for high-pressure slurries, based on the premise that they may last longer than throttling valves in this service. This approach should be investigated; favorable results would be an added incentive for developing hydraulic turbines.

Models have been used successfully by the hydroturbine manufacturers to obtain information for the design of full-scale units installed for hydroelertrir generation. The modcling teehniques leveluped by this industry should be investigated for thẹir usefulness in development of both turbines and pumps for slurry aṕplications.

\subsection{Gas Expanders}

Readily available equipment for power recovery from pressurized gas streams is limited to relatively clean applications below $1350^{\circ} \mathrm{F}$. As temperature is decreased, the amount of entrained solids may be increased. 
Availability

Expanders for the applications listed under identifiers E-I through $E-4^{*}$ are expected to be available from several manufacturers; no major problems requiring appreciable research or development efforts are anticipated. The principal design task for these applications will be to match the operating speed and other characteristics of the expander to those of the compressor or other item of equipment that it will drive, to ensure optimum balance between performance, reliability, efficiency, and cost.

Applications E-5 and E-6 involve operating temperatures in excess of $1350^{\circ} \mathrm{F}$ and particulate-laden gas streams; equ1pment wlll nul be àvailable for these conditions until significant research, development, and testing have been successfully completed. Recommendations for these programs w11l be outlined in the following subsection.

$\underline{\text { Research and Development Needs }}$

Several methods for reducing or eliminating the adverse effects of -entrained particulates were discussed in Sect. 4.4 under problem areas and proposed solutions. All of these methods need considerable additional research and development before they can be used with confidence for the two high-particulate-level expander applications E-5 and E-6. Additional development and testing are also required to develop component cooling methods, select improved blade alloys, and verify other improvements needed for satisfactory operation at temperatures in the 1650 to $1750^{\circ} \mathrm{F}$ range specified for these same applications.

The recommended research and development effort can be divided into three principal phases:

1. a modest addition to the present survey effort leading to the formulation of criteria for future expander development,

2. a series of tests of the various concepts and designs, each directed toward a specific limited objective, and

3. testing of demonstration expanders under actual pilot-plant or demonstration-plant conditions.

\footnotetext{
* See Gas Turbine Questionnaire in Appendix B for equipment operating conditions.
} 
The current survey was limited to manufacturers of industrial hot-gas expanders; therefore, data from one important area were not obtained. Expanders are used as integral components of aircraft gas turbines rather than being sold as end products. Substantially higher. temperatures than those specified for any of the present survey applications are used for aircraft expanders (turbines).* Some of the technology developed for these engines may be applicable to advanced hot-gas expanders for coal conversion applications.

In addition to the aircraft turbine industry, there are indications that soine technology-intensive organizations may be developing expertise for hot-gas expanders; therefore, their suggestions should also be obtained.

To formulate optimum criteria for expander development projects, the requirements of the various processes and the advantages and disadvantages of alternate strategies should be carefully reviewed and analyzed. There are, for example, trade-offs between the costs of solids-gas separators. and those of hot-gas expanders designed for various particulate levels. There are also possible trade-offs between expander inlet temperature and the extent of energy recovery; for instance, ref. 9 states that a reduction in expander inlet temperature from 1800 to $1300^{\circ} \mathrm{F}$ will reduce the directpower output of the expander by only about $25 \%$. This loss, which could be recovered in part by waste-heat boilers, might be economically acceptable if expanders for the higher temperatures were either unduly expensive or short-lived.

The parallel research and development contracts generated as a result of the establishment of these criteria would be directed initially toward specific objectives, which should be limited enough in scope to ensure that each succeeding step is based on a firm foundation. For example, "cold" tests of an expander design that included a particular separation concept might precede testing at higher temperatures; the initial high-temperature tests might then be made without particulates, and so on.

\footnotetext{
* Reference 8 summarizes a proposed coal conversion method that will require a hot-gas expander designed to operate at gas temperatures as high
} as $3000^{\circ} \mathrm{F}$. 
It is anticipated that considerable progress in the development of processes and equipment technology for coal conversion processes will occur during the next several years. It will therefore be necessary to review and update continuously the optimum criteria for expander development and to guide the projects according to the updated criteria. 


\section{CONCLUSIONS AND RECOMMENDATIONS}

This study was initiated.with a twofold objective. First, the present capabilities of U.S. Industry to supply the equipment needed for future coal conversion facilities was to be determined. Conclusions on these. current capabilities are presented in the following subsection. Second, problem areas of the various types of required equipment were to be identified; if necessary, research and development needs, including leadtime requirements, were to be determined for producing equipment of advanced design. Research and development needs are presented in Subsect. 6.2. Unanswered questions raised by this study are considered brief1y in Subsect. 6.3.

\subsection{Availability}

Equipment is available for all clean-stream applications considered in this study. Questions are ralsed only about oxygen compressors and, in a few cases, about equipment for high-temperature applications. The ava11ability of all types of equipment used to handle solids is questionable. High erosion rates lead to short equipment lives; therefore, avallability of equipment becomes a question of acceptable life expectancy, which is primarily concerned with economics. In this section, limitations of available equipment are first discussed, followed by the avallability of questionable items in order of importance. Table 17 summarizes the limits of rotating equipment avallability for coal conversinn facilities.

\section{Limitations of Available Equipment}

In developing the various sets of equipment specifications that appear in Appendix B, information was obtained from several conceptual design reports that are based on coal conversion concepts believed to be representative of fulure coal conversion factlities. in general. Because the more severe operating parameters in these reports were used in developing equipment specifications and because avallable equipment has been identified for all applications within certain limitations, it is concluded that equipment is available for almogt all of the expected clean-stream 
Table 17. Limits of rotating equipment arailabil-ty

\begin{tabular}{|c|c|c|c|c|c|c|c|c|}
\hline \multirow[b]{3}{*}{$\begin{array}{l}\text { Operating } \\
\text { parameter }\end{array}$} & \multicolumn{8}{|c|}{ Limit of specified opesating paramet $\equiv r^{a, b}$} \\
\hline & \multicolumn{2}{|c|}{ Pumps } & \multicolumn{4}{|c|}{ Compressors } & \multirow{2}{*}{$\begin{array}{r}\text { Fydraulic } \\
\text { turbines }\end{array}$} & \multirow[b]{2}{*}{$\begin{array}{l}\text { Gas } \\
\text { expanders }\end{array}$} \\
\hline & Centrif $=g a l$ & Reciprocating & Axial & Centrifugal & Reciprocating & Oxygen & & \\
\hline Flow rate & $200,0=0^{c}$ & $d$ & $e$ & $e$ & $e$ & $\begin{array}{l}350,000^{f} \\
(2,000)^{g}\end{array}$ & $h$ & $100,000^{f}$ \\
\hline Solids content & $60^{i}$ & $60^{i}$ & $0.03^{j}$ & $1.5^{j}$ & & $\mathbf{0}$ & 0 & $\begin{array}{l}0.23^{j} @ 350^{\circ} \mathrm{F} \\
0.15^{j} @ 1,200^{\circ} \mathrm{F} \\
0,06^{j} @ 1,350^{\circ} \mathrm{F} \\
0^{j} @ 1,350^{\circ} \mathrm{F}\end{array}$ \\
\hline Temperature, " $\mathrm{F}$ & 850 & & 700 & 700 & & 400 & 575 & 1,350 \\
\hline Pressure, psía & $4, \mathrm{COO}$ & 4,300 & $e$ & $e$ & $e$ & $\begin{array}{l}600 \\
k\end{array}$ & 4,000 & $\begin{array}{l}225 \text { for clean stream } \\
70 \text { for dirty stream }\end{array}$ \\
\hline $\begin{array}{l}\text { Pressure } \\
\text { head, psial }\end{array}$ & $4,00 c^{m}$ & $a$ & * & & & & 4,000 & \\
\hline Pressure ratio ${ }^{2}$ & & & 48 & 270 & 270 & $40-65$ & & 15 \\
\hline Horsepower & $36,0 \mathrm{CO}$ & $3,000-4,000$ & 60,000 & 60,000 & $10, \mathrm{COO}-12,0 \mathrm{CO}$ & 60,000 & $h$ & 80,000 \\
\hline
\end{tabular}

${ }^{\alpha}$ See Table 2 for limits of cperating parameters encounbered by rotating equipmert in this study.

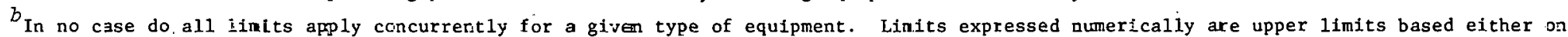
manufacturer's statements or, in the atsence of $s u=h$, the upper iimit of the paramet $\mathrm{r}$ in the equipment list for those items of equipment whici are available. Figure 3 provides upper and lower limits.

$c_{\text {Gallons. per ninute. }}$

$d_{\text {See Eq. (3.5). }}$

$e_{\text {See Fig. } 3 .}$

$f_{\text {Actual cubic feet per minute. }}$

$g_{\text {Tons per day. }}$

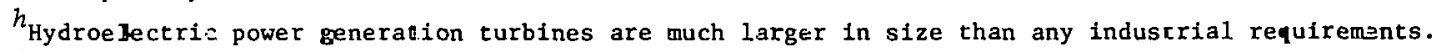

$i$ Weight perceat.

$j_{\text {Grains per actual cubic foot. }}$

$k_{\text {One oxygen compresso: }}$ operates at $960 \mathrm{psia}$, and a sister untt has operated experimentally at 1500 . psia.

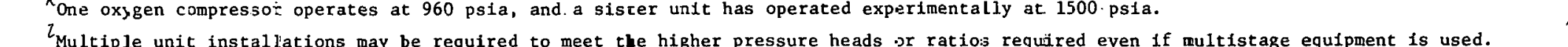

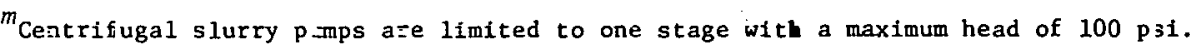


applications likely to be found in future coal conversion facilities. The avallability of oxygen compressors for pressures above 600 psia, however, is marginal. Restrictions on temperature may cause some minor difficulties with all types of equipment; these restrictions vary from one type of equipment to another. Careful specification of operating conditions and proper application of existing technology should minimize or prevent problems likely to be encountered with items of equipment used for clean-stream applications.

Oxygen Compressors. Oxygen compressors are readily available for compressing up to 2000 TPD of oxygen to discharge pressures of about 600 psia. One oxygen compressor is known to be operating with a discharge pressure of 960 psia, and a sister unit has reportedly been operated experimentally at 1500 psia; however, these cases are exceptional. Most oxygen compressors operating at these higher pressures have been destroyed by explosion or fire. Compressors capable of safely compressing 2000 TPD of oxygen to 1250 psia are yet to be developed; yet they are critical to a number of processes such as HYGAS and BI-GAS.

Temperature Limitations for Clean-Stream Applications. Although cooler operating temperatures are desirable from an equipment designer's point of view, pumps have been built for temperatures as high as $850^{\circ} \mathrm{F}$ and above. Compressors might also be designed for comparable temperatures; however, it is generally preferable to maintain lower temperatures because of equipment costs and operating efficiencies. It is recommended that the inlet temperature $\left(600^{\circ} \mathrm{F}\right)$ of compressor $\mathrm{MH}-2^{*}$ be reduced significantly inasmuch as gas temperatures increase during compression. Expander operation, even in the absence of particulates, is limited to about $1350^{\circ} \mathrm{F}$ unless blade and case cooling are employed.

Availability of Questionable Equipment

Slurry pumps are the most critical equipment items required for coal conversion facilities for which availability is questionable. Compressors (in particular, fans and blowers) for dirty-gas streams are also not readily conditions.

* See equipment questionnaires in Appendix B for equipment operating 
available. Hot-gas expanders are critical to some coal conversion prócesses, and their development needs to be pursued. Hydraulic turbines for slurry applications are desirable but not currently available.

Slurry Pumps. Without reliable slurry pumps, coal conversion is impractical. Availability and reliability are really questions of acceptable equipment life expectancy and maintenance frequency. Because of high rates of erosion, maintenance work may be nécessary as often as every 3 weeks and will frequently involve the replacement of severely eroded parts.

In the course of this study, no centrifugal slurry pumps were ident1fied that operate continuously for more than 1 week at a time; however, maintenance does not normally disrupt the processes 1nvolved, primarily mineral beneficiation processes, inasmuch as these pumps were not required to be in operation around the clock. Current centrifugal pumps are of single-stage design and are limited to a pressure rise of <100 psi; if. required, higher heads may be obtained by placing several single-stage' units in series. If multistage centrifugal slurry pumps can be developed, manufacturers foresee a maximum outlet pressure of 600 to 800 psia.

High-head applications requiring pressure rises of greater than about 600 psi are handled currently by reciprocating pumps. Thus, if life expectancy and maintenance requirements are acceptabie, equipment is avall." able for low- and high-head applications. This situation either poses a need for intermediate-pressure-head multistage centrifugal olurry pumps or requires the installation of multiple single-stage units in series. The frequency of maintenance is expected to be about equal for centrifugal and reciprocating slurry pumps; however, maintenance will be more extensive for centrifugal pumps.

Slurry pumps need to be designed with easily replaceable subparts and liners for high erosion rate areas. Advanced construction materials should also be used, and velocities within the pump should be limited to a maximum of 100 fps. Centrifugal pumps must be operated at maximum efficlency to minimize wear.

Compressors for Dirty-Gas Streams. Compressors capable of handling $\therefore$ particulate-laden streams may also be important; however, removing particulate matter by cyclones may solve the problems of severe particulate erosion of applications FB-6 through FB-9. FB-5 particulate loading is 
already low inasmuch as the gas, as provided for in the flow sheet, has already passed through cyclones and an electrostatic precipitator. Axial flow compressors would normally be specified for the FB series of applications; if particulates are not removed, however, double-flow centrifugal compressors should be specified. Centrifugal compressors are more rugged than axial flow compressors and were recommended by several manufacturers. FB-6 and FB-7 require special construction materials not only because of the high temperature $\left(700^{\circ} \mathrm{F}\right)$ but also because of aggregate erosion caused by this temperature. As temperature is increased, the tolerance of both compressors and expanders for particulates is decreased.

Expanders for High-Temperature, Dirty-Gas Streams. Expanders may or may not be required for first-generation coal conversion facilities, depending on the processes chosen for commercialization. Some processes require expanders to be justified economlcally; in other cases expanders may be desirable but are not absolutely necessary. Current technology limits expanders to a maximum temperature of about $1350^{\circ} \mathrm{F}$, but design practice limits temperatures to about $1250^{\circ} \mathrm{F}$. Higher temperatures will require blade and housing cooling as well as essentially complete particulate removal if present expander designs are used. Although a number of integrated particulate removal-expander processes are being studied, none have been demonstrated.

Hydraulic Turbines for Slurry Applications. Hydraulic turbines for slurry applications are not available; on the other hand, they do not appear. to be critical. Slurry applications for turbines were postulated from the processes studied but were not included by those preparing the conceptual designs. Turbines may be desired for power recovery from high-pressure slurry streams, and some manufacturers have expressed the opinion that such untts may serve better for pressure let-down purposes than valves. Anticipated problems with these units are expected to be more severe than analogous slurry-pump problems.

\subsection{Research and Development Needs}

The most critical items of equipment requiring research and development are slurry pumps and oxygen compressors, after which come fans and blowers 
for low-pressure, dirty-gas streams. Next, and less critica1 except for a few processes, are expanders. Hydraulic turbines for slurry applications may be desirable, but are not necessary to justify a process. Particular areas of research and development work are discussed below.

\section{Slurry Pumps}

As previously discussed in Subsect. 6.1, single-stage centrifugal pumps for low-head applications and reciprocating pumps for high-head applications are available for slurry handling, although short pump life and frequent maintenance is to be expected. Both of these pumps need to be improved to operate for a longer time between maintenance and/or replacement. Multistage centrifugal slurry pumps are essentially nonexistent and need to be developed for heads as high as 600 to 800 psi (most manufacturcre seo 600 to 800 psia as a maximum outlet pressure from such pumps). These multistage pumps are needed to bridge the gap between single-stage centrifugal pumps and reciprocating units. The following items should be considered in designing slurry pumps.

1. Pump design should be based on a thorough knowledge of the specific application in which the pump will. be used. It is essential that the pump be designed to operate at its highest efficiency to minimize wear, particularly if it is of centrifugal design.

2. Easily replaceable liners and subparts for high-wear areas should be incorporated in slurry-pump designs to reduce maintenance turnaround time.

3. Relative velocities in excess of $100 \mathrm{fps}$ at no point should be included in slurry pump designs, unless erosion rates have been otherwise reduced significantly.

4. Advanced cunstruction materials, such as hard metals and ceramics, should be developed for use in fabricating liners, subparts, and other parts of the pump such as the impeller to minimize the effects of erosion. Surface-hardening techniques also should be pursued.

Two additional matters must also be considered in establishing a research and development plan. First, the market demand for slurry pumps needs to be more firmly established. Inasmuch as the status and direction 
of coal conversion commercialization is still unclear, most manufacturers are unwilling to commit research dollars to high-risk development projects for which they foresee no return on their investment. If the market picture remains unresolved, government funding of slurry-pump development will be required if these units are to be developed. The second matter is the need for slurry-pump testing facilities. Most manufacturers test pumps only with water, and those few manufacturers who have slurry-testing facilities have limited testing capabilities. Because of the difficulties of developing and maintaining adequate slurry test facilities, a testing center available to all manufacturers needs to be established; however, responding manufacturers have expressed concern about possible requirements leading to disclosures of proprietary information on pump design if government funding of such a center is involved.

\section{Oxygen Compressors}

Several coal conversion processes require high-pressure oxygen at about 1250 psig; one or more air-separation plants producing about 2000 TPD of oxygen are specified in the conceptual designs. Some compressor designers and operators prefer to limit outlet pressures for oxygen compressors to a maximum of about 600 psia to minimize the risk of explosion and/or fire, but others are willing to operate at pressures as high as 1500 psia. Because of the high reactivity of oxygen with metals in the presence of heat, the following measures are recommended.

1. Temperatures should not exceed $392^{\circ} \mathrm{F}$ in any part of the oxygen stream in the compressor and should be kept even lower as pressure is increased.

2. Design, construction, and installation of the compressor should preclude any rubbing contact between rotating and stationary parts which could lead to explosion and/or fire.

3. Strict cleanliness control should be practiced during manufacture, assembly, and maintenance of the compressor, the lack of which could also lead to explosion and/or fire.

4. Reliable temperature-monitoring and flash-detection devices should be used. Further development of the latier devices should be considered. 
Fans and Blowers

Fans and blowers for particulate-laden streams need to be developed. Again, design and construction materials are important. The technology that is being considered or developed for handling particulates in hot-gas expanders should be reviewed for its applicability to fans and blowers.

\section{Expanders}

A number of particulate-removal techniques have been presented by their developers. Some of these techniques have been incorporated into actual expander designs, but others have not. All of them are discussed in Subsect. 4.4 and should be thoroughly investigated. Improved blade-cooling terhniques and construction materials need to be developed for high-temperature applications.

\section{Hydraulic Turbines}

Hydraulic turbines for slurry applications are not critical items of equipment; however, technology developed for slurry pumps may also be used in developing slurry turbines. Development of these two types of equipment should be coordinated. The benefits of using hydraulic turbines for slurry pressure let-down should be considered.

\subsection{Add1tional Areas of Study}

In the course of this survey, a number of questions have been raised that could not be investigated in the time avallable. Several of these questions may have a significant effect on the course of research and development plans and should therefore be considered.

An important area of study not fully addressed fis the adaptability of technology that has been developed for other industries to problems of equipment availability for the coal conversion industry. The experience of the mineral beneficlation and slurry pipeline industry should be thoroughly investigated, as well as the experience of coal conversion pilot plants, to establish more fully the level of existing technology and thereby to obtain a basis for future slurry-pump development. The aircraft turbine industry 
may also be able to provide valuable high-temperature technology applicable to the design of hot-gas expanders.

The lead-time requirement for development of unavallable equipment was addressed brlefly in the vartous questlonnaires; however, the magnitude and nature of developmental work and the related costs were not considered. These aspects of development need to be determined to establish research and development programs, which we hope wili lead to development of the required equipment by the time it is needed.

The information obtalned during this study needs to be compared to equipment requirements for those processes most likely to be commerclalized. In cases 1n which equipment avallability is questionable, the possibility of modifying the process should be considered. The expenses involved in "equilpment development and use of the equipment afterward need to be compared to the economics and reliablitty of the modified process.

The avallabllity of phystcal property data for slurries is limited. A program to expand this data bese for the use of pump manufacturers needs to be considered.

The factors responstble for high hydroturblne efficlencles should be studied for thelr applicabllity to pump design. The modeling techniques that have been developed and successfully: used by the hydroturbine Industry for the design of the Imense turbines installed in hydroelectric generating stations should also be Investigated. These techniques may be partlcularly useful in the development of pumps and turbines for slurry applications. 
Appendix A

PROCESSES FORMING A BASIS FOR EQUIPMENT SPECIFICATIONS 


\section{REFERENCES}

1. R. J. McMahon, Chemical Engineering Catalog, Reinhold Pub1. Co., Stamford, Conn., 1977.

2. Hydraulic Institute, Hydrauzic Institute Standards, 13th ed., Cleveland, Ohio, 1975.

3. Thomas Register of American Manufacturers and Thomas Register CataZogue File, Thomas Pub1. Co., New York, 1976.

4. Information Handling Service, Visual Search Microfilm Plant Engineering Service, Englewood, Colo., October 1976.

5. A. J. Miller, "Power Expander Centrifuge," U.S. Patent No. 3,905,197, Sept. 16, 1975.

6. J. P. Balfoort, "Power Recovery Systems and Hot Gas Expanders," pp. 1-7 in Proceedings of the Third Turbomachinery Symposium, College Station, Texas, Oct. 15-17, 1974, Texas A. \& M. Univ. Press, College Station, Tex., 1974.

7. L. M. Stettenbenz, "Minimizing Erosion and Afterburn in the Power Recovery Gas Expander," presented at the Petroleum Mechanical Engineering and Pressure Vessels and Piping Conference, Denver, Colo., September 1970 (available as Form 3999 from Ingersoll-Rand, Phillipsburg, N.J.).

8. L. P. Harris and R. P. Shaw, Energy Conversion Altermatives Study ECAS - General Electric Phase II Final Report: Volume II, Advanced Energy Conversion Systems - Conceptual Designs: Part 3, Open Cycle Gas Turbines and Open Cycle MHD, NASA-CR-134949, prepared by Corporate Research and Meviplopment, General Elcctrie Company, fur National Aeronautics and Space Administration, Energy Research and Development. Administration, and National Science Foundation, Washington, D.C.,' December 1976 , pp. 4.5-1 to $4.5-49$. 
9. A. L. Wilson, Mechanical Development Recommendations, Interim Report, FE-2240-44, C. F. Braun and Co., Alhambra, Calif., June 1977, p.. $156-67$. 


\section{PAGES A-1 to WERE INTENTIONALLY LEFT BLANK}


Appendix A

PROCESSES FORMING A BASIS FOR EQUIPMENT SPECIFICATIONS

The seven processes forming a basis for equipment specifications are presented briefly in this appendix. The reference from which information was obtained on each process is cited along with basic information on coal feed and product flow rates obtained from the reference. The location and capacity of equipment serving as models for equipment specifications are also given. Simplified block flow diagrams show the arrangement of process units within the cuntext of the overall process.

Information on processes forming bases for supplemental information is also provided. 


\section{BI-GAS Process}

\section{Reference}

Energy Research and Development Administration, 250-MiZZion-SCFD High-BTU Gas Plant, ERDA 76-48, Process Evaluation Group - Mineral and Material Research and Development, Morgantown, W. Va., (March 1976).

Coul Feed

1. Westcrn Kentucky 非1 seam: 13,080 TPD (13,070 Btu/1b)

2. Montana subbituminous: 20,850 TPD $(8,816 \mathrm{Btu} / 1 \mathrm{~b})$

\section{Products}

1. Gas: $250 \mathrm{MM}$ scfd (946 Btu/scf)

2. Gas: $250 \mathrm{MM}$ scfd (951 Btu/scf) 
Table A.1. Equipment Included in survey - BI-GAS process

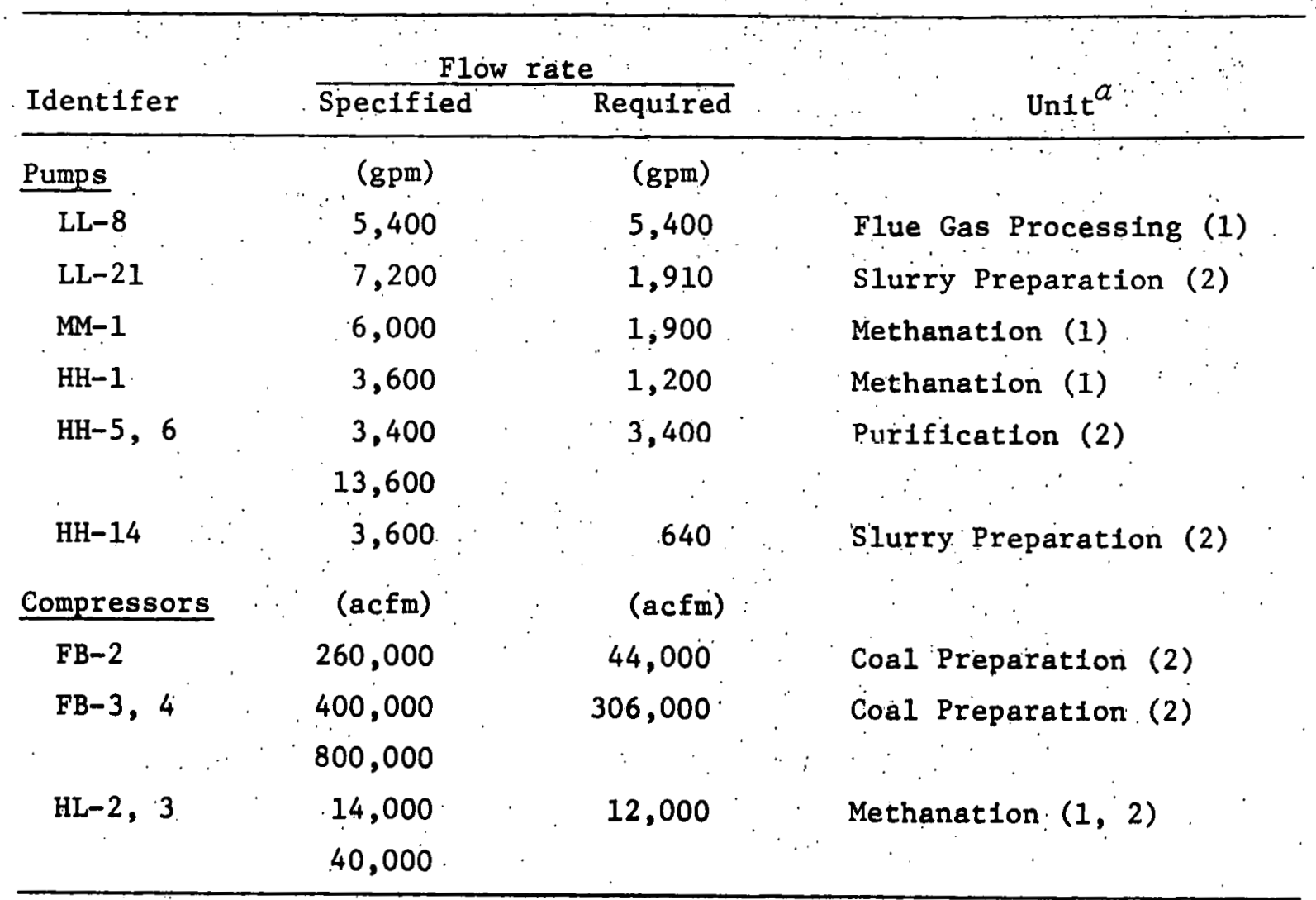

$a_{\text {Number }}$ in parantheses corresponds to 1 and 2 in above sections. 


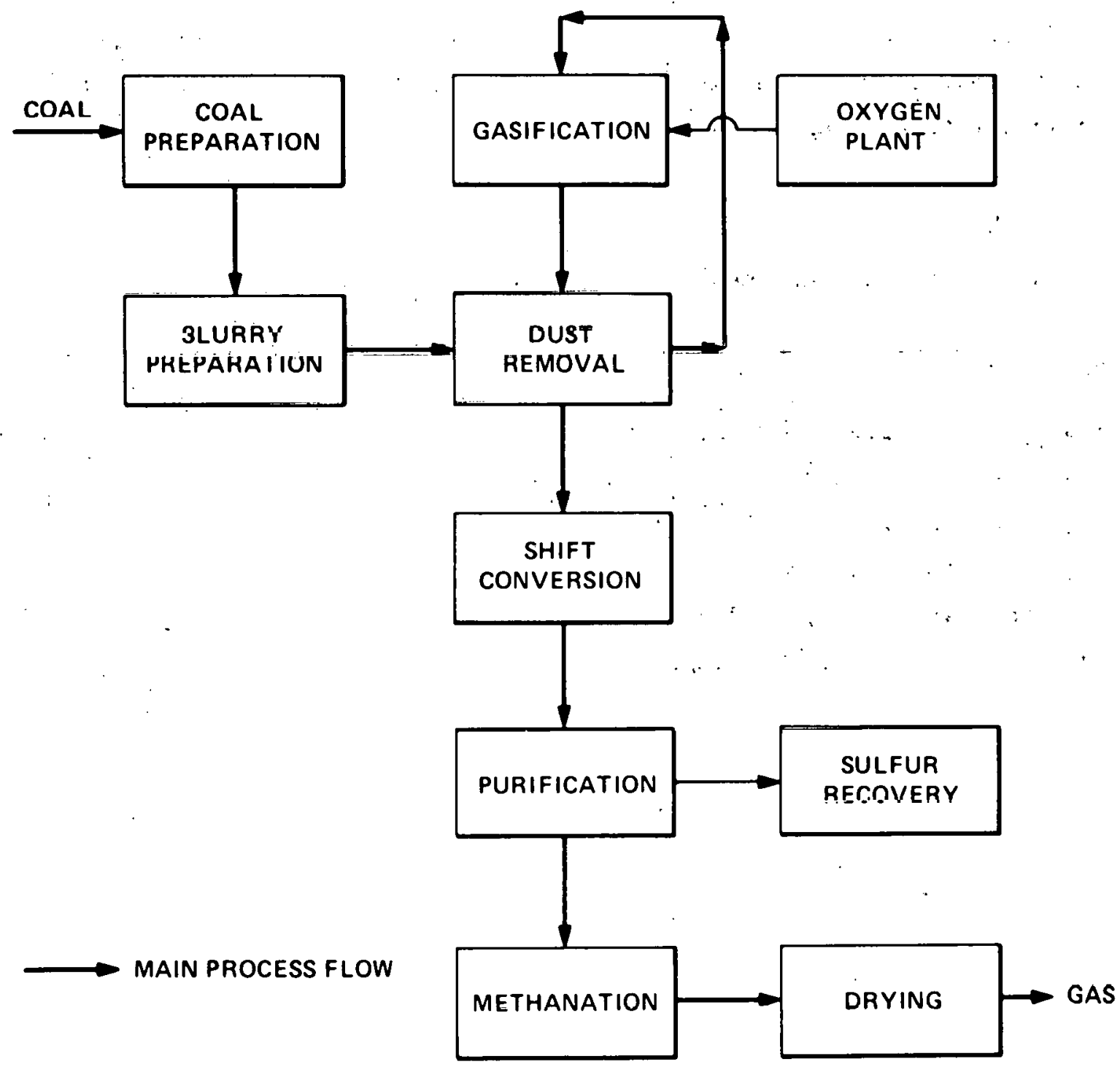

F1g. A.1. Process unit flow sheet - BI=GAS process. 


\section{Coalcon Process}

\section{Reference}

E. T. Coles, Commercial Plant Process Evaluation Report, report prepared under Contract No: : E (49-18)-1736 with Energy Research and Development Administration, Coalcon, New York, N.Y., (August 1975).

Coal Feed

Illinols, Indiana, and Kentucky: 14,760 TPD $(12,216 \mathrm{Btu} / \mathrm{lb})$

\section{Products}

Gas: $105 \mathrm{MM}$ scfd $(1,031 \mathrm{Btu} / \mathrm{scf})$

Heavy fuel oil: 2486 TPD $(16,443 \mathrm{Btu} / \mathrm{lb})$

Light fuel oil: 926 TPD $(18,614 \mathrm{Btu} / \mathrm{lb})$

Liquified petroleum gas: 415 TPD (21,474 Btu/1b)

Ammonia: $48 \operatorname{TPD}(9,750 \mathrm{Btu} / \mathrm{lb})$

Sulfur: 353 TPD $(3,980 \mathrm{Btu} / 1 \mathrm{~b})$ 
Table A.2. Equipment included In survey - Coalcon process

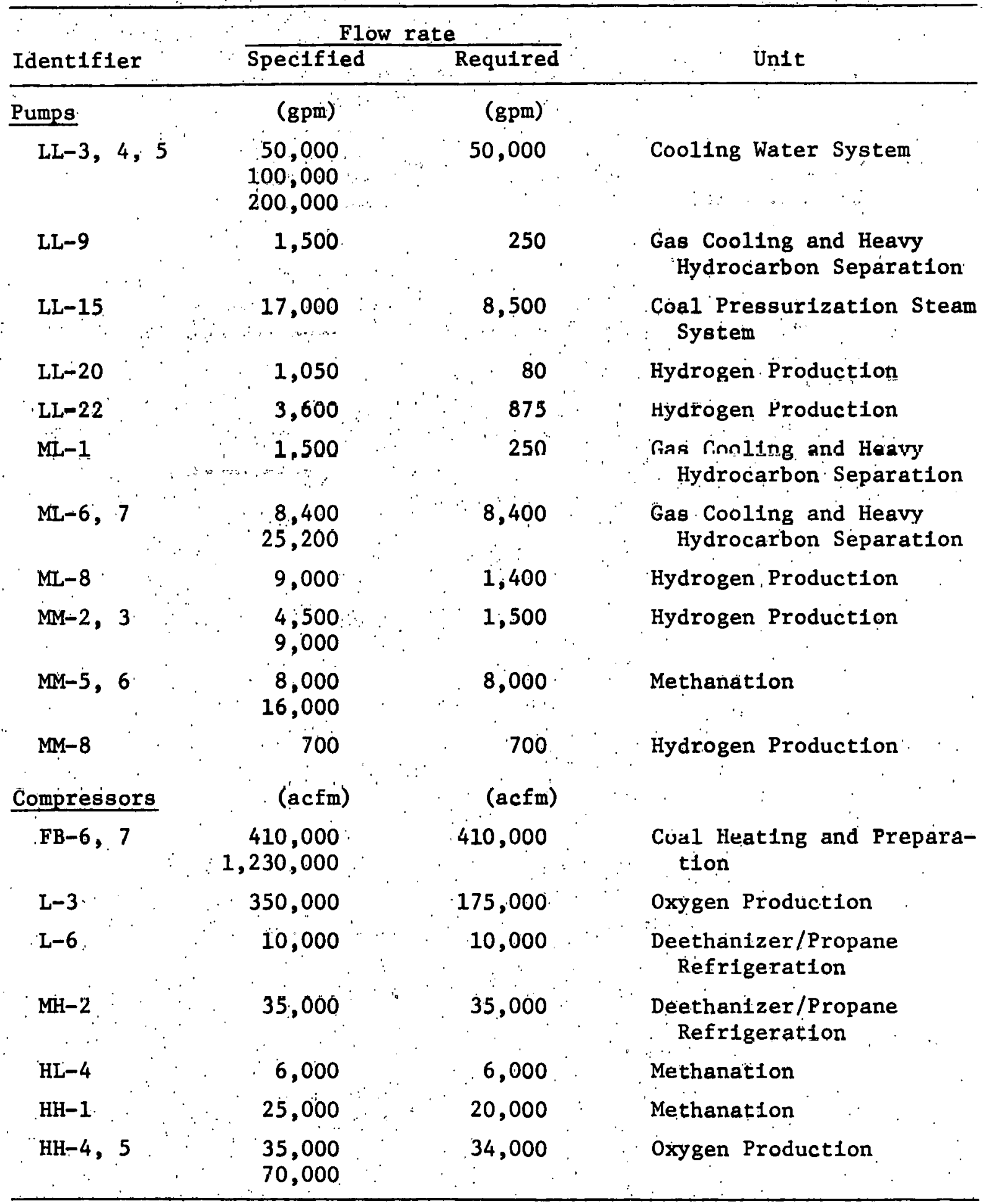




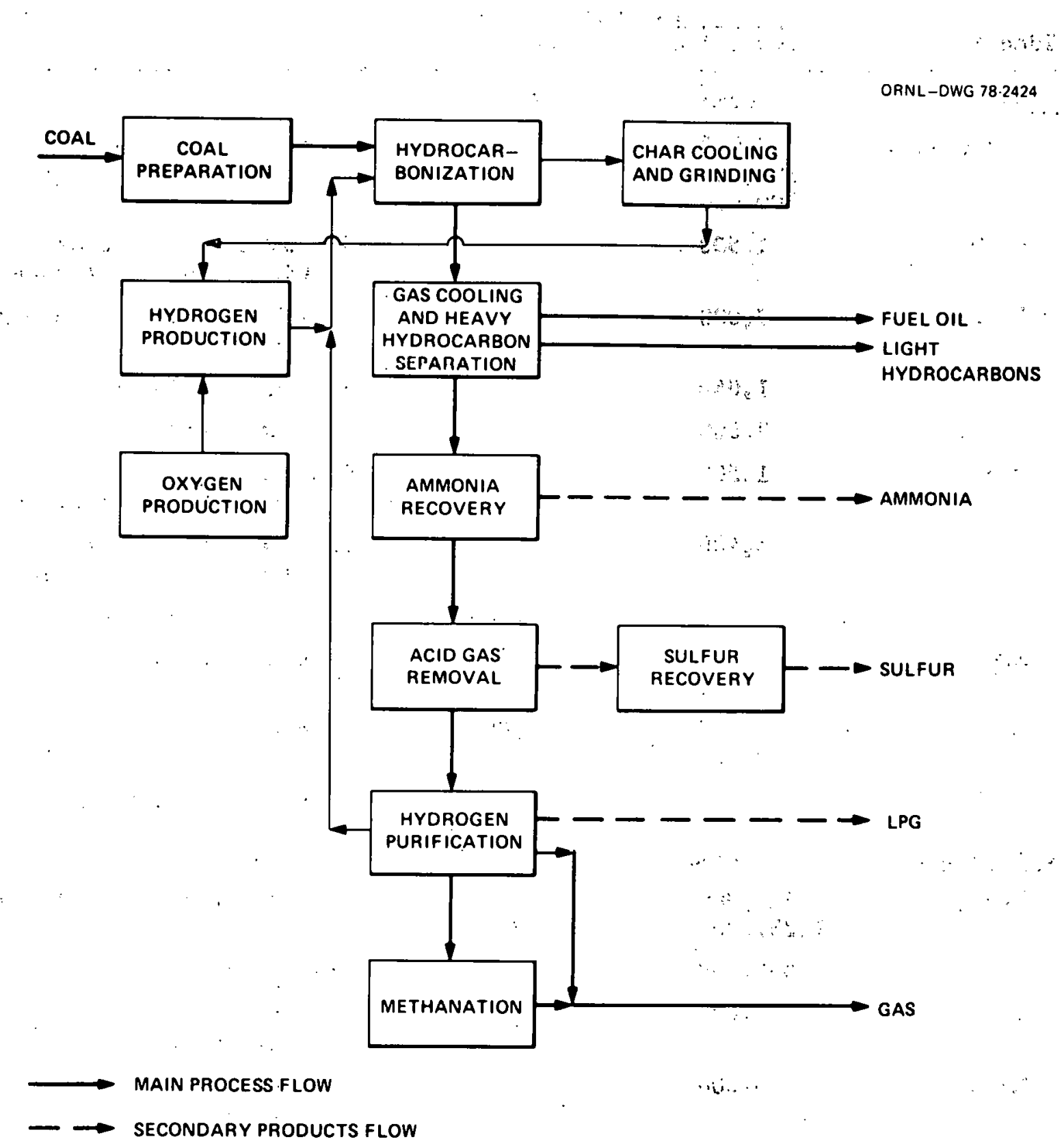

Fig. A.2. Process unit flow sheet - Coalcon process. 


\section{Fischer-Tropsch Process}

\section{Reference}

R. M. Parsons Co., OiZ and SNG by Fischer-Tropsch Complex, R\&D Report No. 114, Interim Report No. 3 (Draft), under Contract No. E (49-18)-1775 with Energy Research and Development Administration, Pasadena, Calif. (no date).

\section{Coal Feed}

I11no1s, Indiana, and Kentucky: 40,000 TPD $(12,550 \mathrm{Btu} / 1 \mathrm{~b})$

\section{Products}

Gas: $260 \mathrm{MM}$ scfd $(1,035 \mathrm{Btu} / \mathrm{scf})$

Naptha: 2,378 TPD $(20,000 \mathrm{BPD})(20,625 \mathrm{Btu} / \mathrm{lb})$

Diesel fuel: 2,105 TPD (16,000 BPD) $(20,255 \mathrm{Btu} / 1 \mathrm{~b})$

Fuel oil: 713 TPD (5,000 BPD) $(19,865 \mathrm{Btu} / \mathrm{lb})$

Alcohols: 458 TPD (4,000 BPD) $(12,505 \mathrm{Btu} / \mathrm{lb})$

Liquified petroleum gas: $343 \mathrm{TPD}$ ( $(3,500 \mathrm{BPD})(21,035 \mathrm{Btu} / 1 \mathrm{~b})$

Sulfur: $1,000 \mathrm{TPD}(3,990 \mathrm{Btu} / \mathrm{lb})$ 
Table A.3. Equipment included in survey - Fischer-Tropsch process

\begin{tabular}{|c|c|c|c|}
\hline \multirow[b]{2}{*}{ Identifier } & \multicolumn{2}{|c|}{ Flow rate } & \multirow[b]{2}{*}{ Unit } \\
\hline & Specified & Required & \\
\hline Pumps: & $(\mathrm{gpm})$ & (gpm) & . \\
\hline LL-1 & 2,500 & 1,200 & Water Reclamation \\
\hline$L L-3,4,5$ & $\begin{array}{r}50,000 \\
100,000 \\
200,000\end{array}$ & 50,000 & Raw Water System \\
\hline$L L-18$ & 8,000 & 4,031 & Coal Preparation \\
\hline ML-2 & 5,800 & 2,900 & Process Gasification \\
\hline $\mathrm{ML}-3$ & 440 & 220 & $\begin{array}{l}\text { Fischer-Tropsch Syn- } \\
\text { thesis }\end{array}$ \\
\hline $\mathrm{ML}-4$ & 300 & 150 & $\begin{array}{l}\text { Fischer-Tropsch Syn- } \\
\text { thesis }\end{array}$ \\
\hline $\mathrm{ML}-5$ & 620 & 310 & $\begin{array}{l}\text { Fischer-Tropsch Syn- } \\
\text { thesis }\end{array}$ \\
\hline ML-9 & 10,000 & 4,620 & Process Gasification \\
\hline ML-10 & 5,000 & 1,335 & Process Gasification \\
\hline $\mathrm{HH}-3,4$ & $\begin{array}{l}15,600 \\
31,200\end{array}$ & 4,600 & Power Generation \\
\hline $\mathrm{HH}-9$ & 2,500 & 1,250 & Water Reclamation \\
\hline \multicolumn{4}{|l|}{ Compressors } \\
\hline$\cdot$ & $(a c f m)$ & $(\operatorname{acfm})$ & \\
\hline ML-1 & 82,000 & 41,000 & $\begin{array}{l}\text { Fischer-Tropsch Syn- } \\
\text { thesis }\end{array}$ \\
\hline$M L-3$ & 20,000 & 10,000 & Methanation \\
\hline MH-1 & 400 & 180 & Water Reclamation \\
\hline HL-6 & 10,000 & 3,600 & Methanation \\
\hline Hydraulic Turbines & $(\mathrm{gpm})$ & & \\
\hline $\mathrm{T}-19$ & 2,168 & & Water Reclamation \\
\hline
\end{tabular}


ORNL-DWG 78.2425

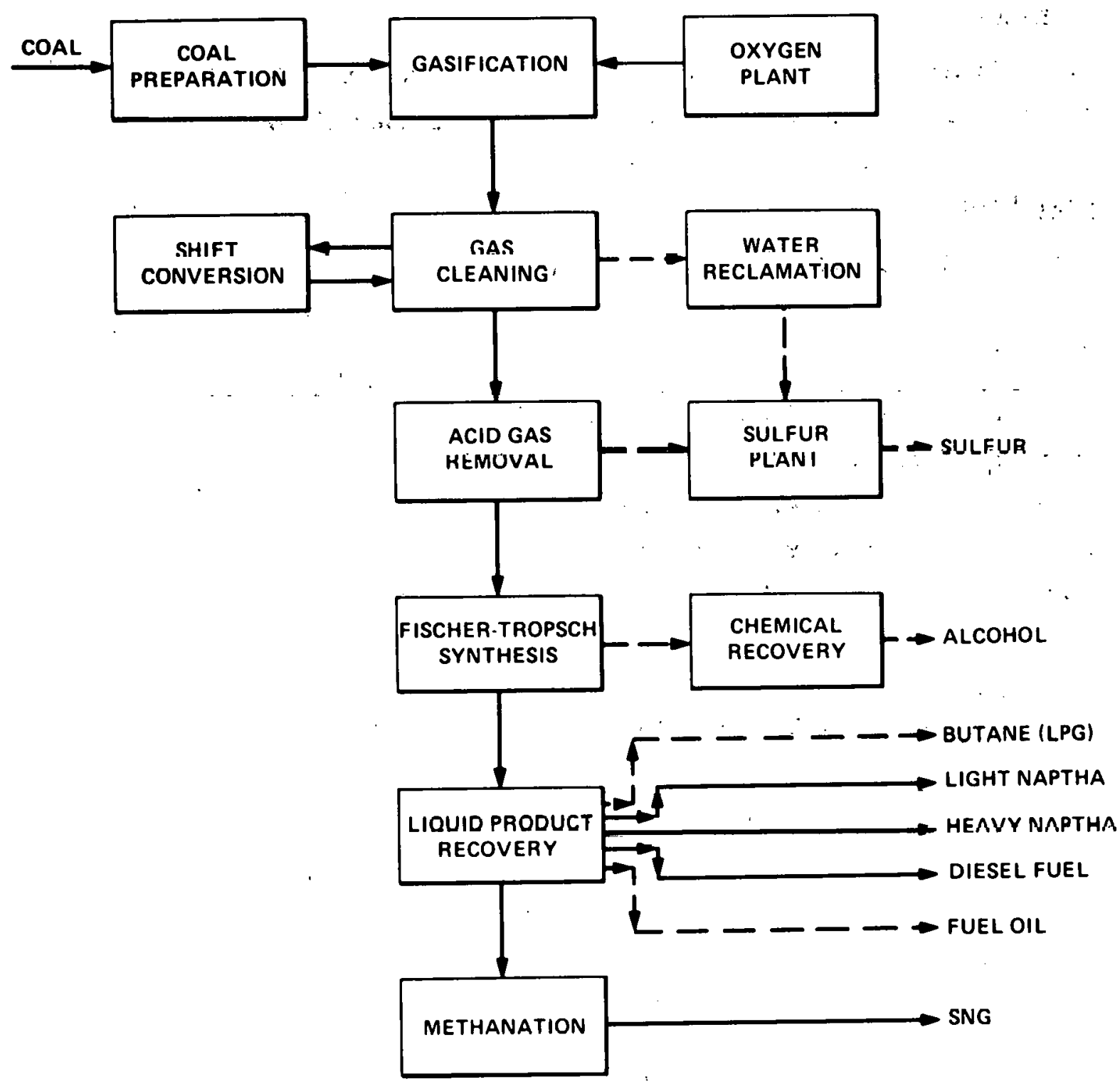

MAIN PROCESS FLOW

SECONDARY PRODUCTS FLOW

Fig. A.3. Process unit flow sheet - Fischer-Tropsch process. 


\section{Hydrocarbonization Process}

\section{Reference}

J. M. Holmes et al., Hydrocarbonization Process:Evaliation Report, ORNL-5212 (Draft), Oak Ridge National Laboratory, (September 1976):

\section{Coal Feed}

I111nols No. $6: 46,210$ TPD $(12,705 \cdot \mathrm{Btu} / \mathrm{Ib})$

\section{Products}

Fuel o11: 22,930 bb1/day $(6.31 \mathrm{MM} \mathrm{Btu/bb1})$ *

Gas: $63.67 \mathrm{MM}$ scfd $(985 \mathrm{Btu} / \mathrm{scf})$

Char: 18,178 TPD $(14,821 \mathrm{Btu} / 1 \mathrm{~b})$

Sulfur: 519 TPD. $(3,990 \mathrm{Btu} / \mathrm{ib})$

Ammonia: $193 \mathrm{TPD}(9,800 \mathrm{Btu} / \mathrm{lb})$

\footnotetext{
*Naptha, 2,174 bbl/day; fuel oil, 20,756 bb1/day.
} 
Table A.4. Equipment included in survey - Hydrocarbonization process

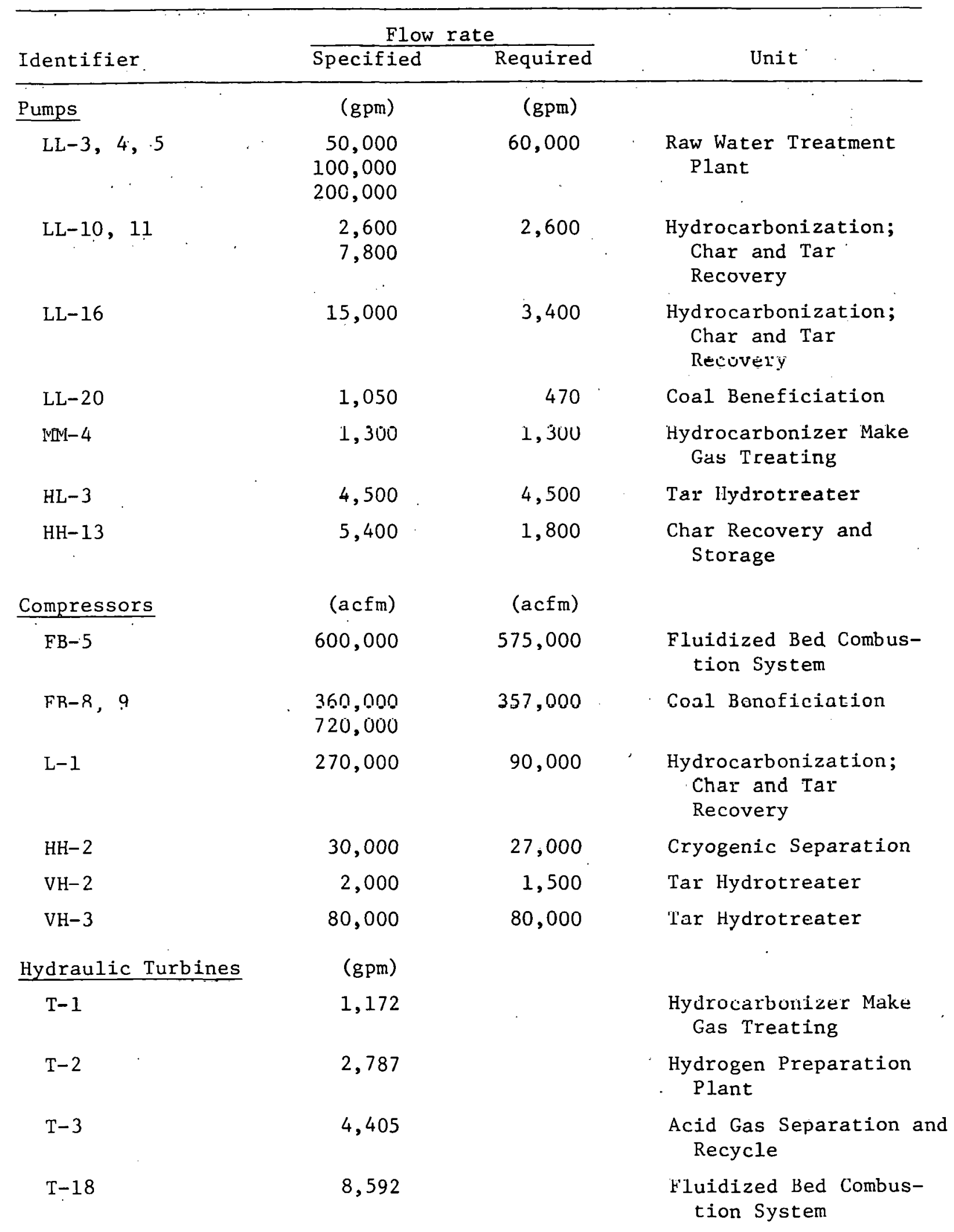


Table A.4 (continued)

\begin{tabular}{|c|c|c|c|c|}
\hline \multirow[b]{2}{*}{ Identifier } & & \multicolumn{2}{|c|}{ Flow rate } & \multirow[b]{2}{*}{ Unit } \\
\hline & & Specified & $\overline{\text { Required }}$ & \\
\hline Gas Expanders & & $(\operatorname{acfm})$ & & \\
\hline$E-1$ & & $60 \therefore$ & . & Tar Hydrotreater \\
\hline$E-2$ & $\because$ & 16,000 & : & $\begin{array}{l}\text { Fluidized Bed Combus- } \\
\text { tion System }\end{array}$ \\
\hline$E-3$ & $\therefore$ & 85,000 & & $\begin{array}{l}\text { Fluidized Bed Combus- } \\
\text { tion System }\end{array}$ \\
\hline
\end{tabular}




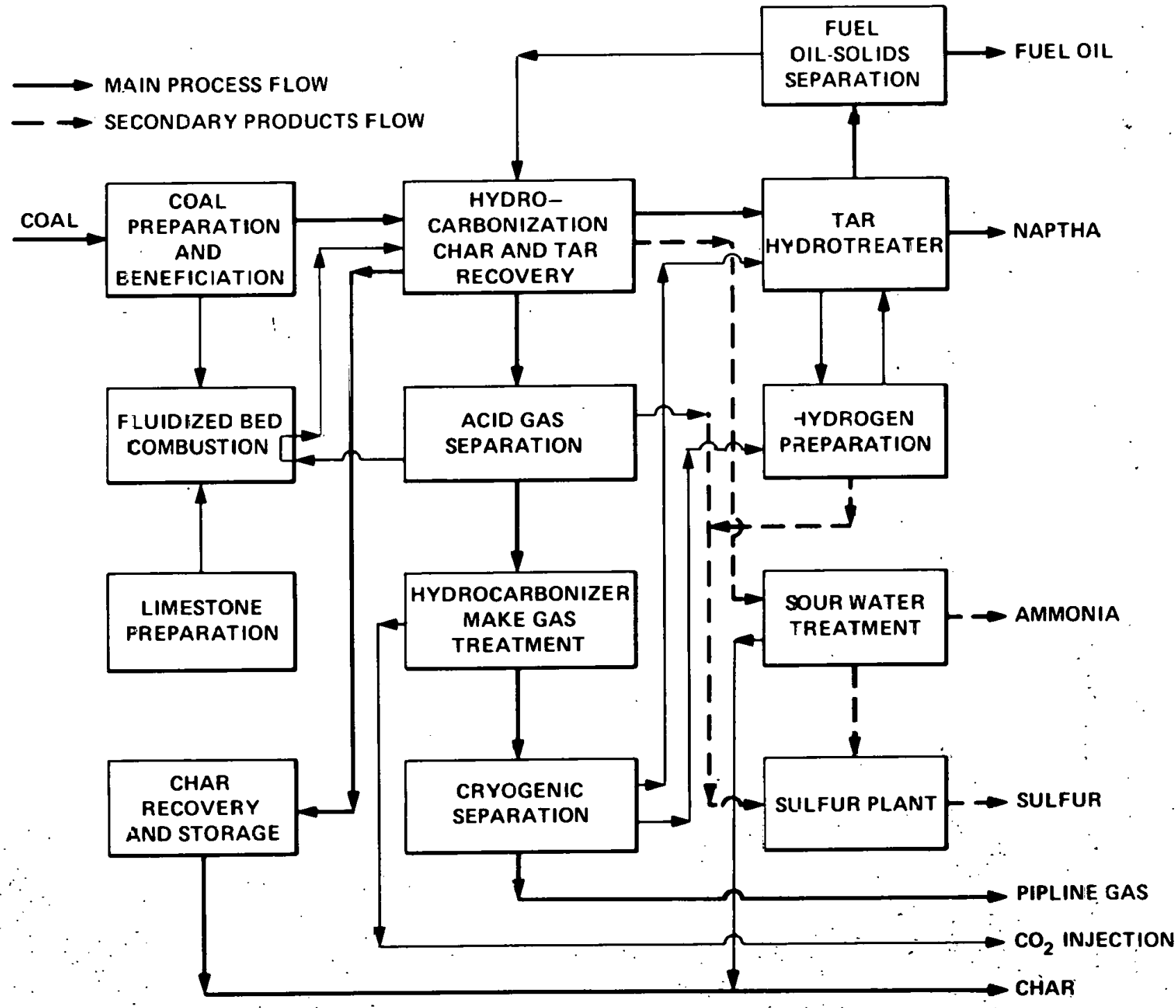

Fig. A.4. Process unit flow sheet - Hydrocarbonization process. 


\section{HYGAS Process}

\section{Reference}

Energy Research and Development Administration, IGT HYGAS Hydrogasification

Process, ERDA 76-47, Process Evaluation Group - Mineral and Materia1 Research and Development;: Morgantown, W. Va., (March 1976).

\section{Coal Feed}

1. Pittsburgh seam: 16,200 TPD $(13,053 \mathrm{Btu} / \mathrm{lb})$

2. Montana subbituminous: 22,200 TPD $(8,806 \mathrm{Btu} / \mathrm{lb})$

\section{Products}

1. Gas: $250 \mathrm{MM} \operatorname{scfd}(965 \mathrm{Btu} / \mathrm{scf})$

B-T-X: $25,3001 \mathrm{~b} / \mathrm{hr}(136,000 \mathrm{Btu} /$ gal $)$

2. Gas: $250 \mathrm{MM} \mathrm{scfd}(965 \mathrm{Btu} / \mathrm{scf})$

B-T-X: 23,200 lb/hr $(136,000 \mathrm{Btu} / \mathrm{gal})$ 
Table A.5. Equipment included in survey - HYGAS process

\begin{tabular}{lrrl}
\hline & \multicolumn{2}{c}{ Flow rate } & \\
\cline { 2 - 3 } Identifier & Specified & Required & Unit $^{a}$ \\
\hline Pumps & (gpm) & (gpm) & \\
\hline LL-21 & 7,200 & 578 & S1urry Preparation (2) \\
HL-2 & 8,000 & 4,800 & Dust Removal (1) \\
HH-12 & 4,800 & 400 & S1urry Preparation (1) \\
HH-14 & 3,600 & 290 & Slurry Preparation (2) \\
Compressors & $($ acfm) & $($ acfm) & \\
L-2 & 220,000 & 70,000 & Coal Pretreatment (1) \\
HL-1 & 10,000 & 7,620 & Methanation (1) \\
\hline
\end{tabular}

"Number in parentheses corresponds to 1 and 2 in above section. 


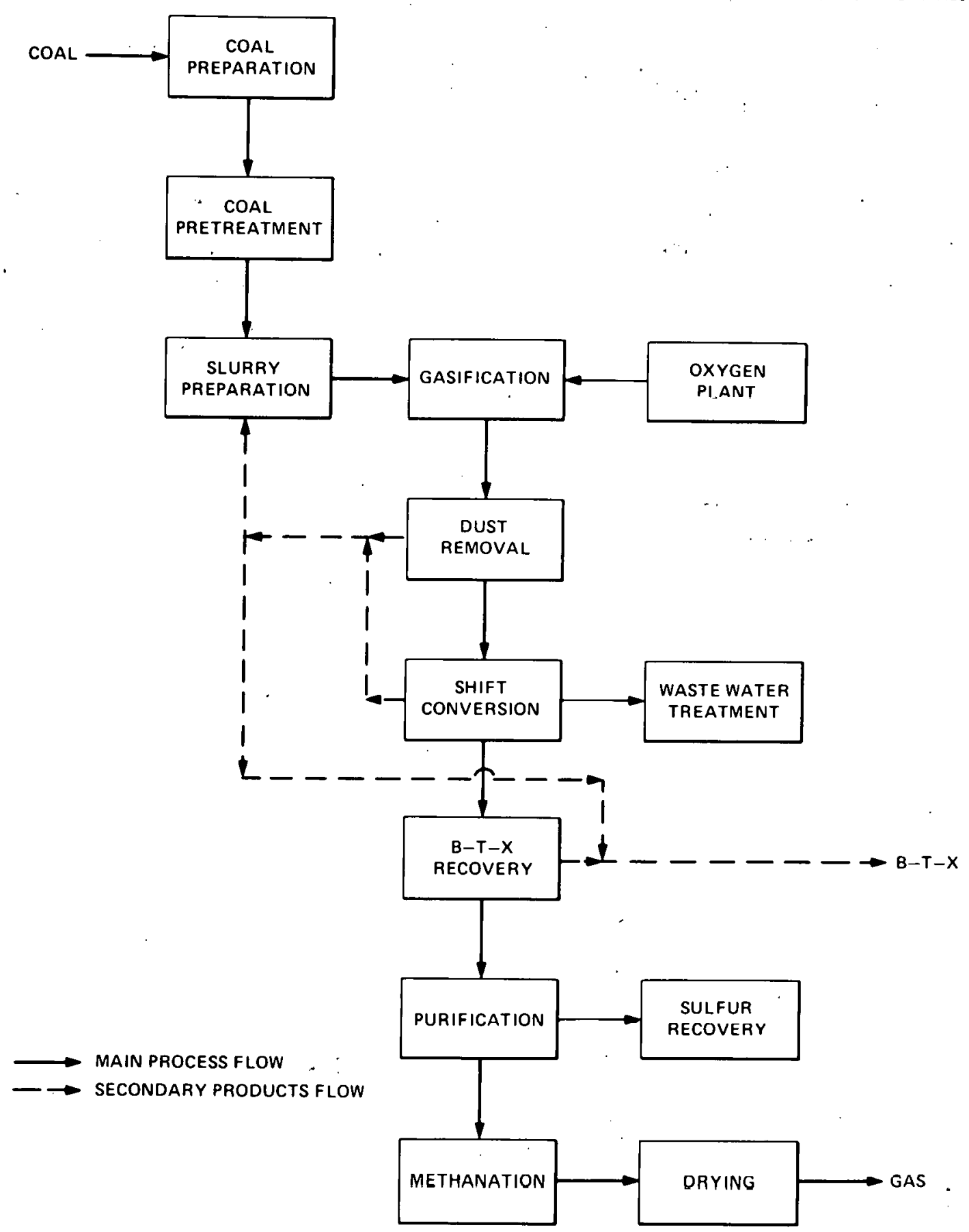

NOTE: FOR MONTANA SUBBITUMINOUS COAL, THE COAL PRETREATMENT UNIT IS NOT REQUIRED. ALSO, WATER IS USED FOR SLURRY MAKE.UP; THEREFORE, WATER IS RECYCLED FROM THE DUST REMOVAL UNIT TO SLURRY PREPARATION WITH EXCESS WATER GOING TO WASTE WATER TREATMENT. PRODUCT B-T-X IS RECOVERED DIRECTLY FROM SHIFT CONVERSION AND B-T-X RECOVERY UNITS.

Fig. A.5. Process unit flow sheet - HYGAS process. 


\section{Lurgi Process}

\section{$\underline{\text { Reference }}$}

Energy Research and Development Administration, 250-MiZZion-SCFD Gas PZant, ERDA 76-7, Process Evaluation Group - Mineral and Material Research and Development, Morgantown, W. Va., (August 1975).

\section{Coal Feed}

New Mexico: 23,904 TPD (8,664 Btu/1b)

\section{Produr.ts}

Gas: 250 MM scfd (934 Btu/scf)

Ammonia: 104.7 TPD $(9,800 \mathrm{Btu} / \mathrm{lb})$

Tar oil: 68,600 gpd $(17,920 \mathrm{Btu} / \mathrm{lb})$

Naptha: 36,000 gpd $(19,150 \mathrm{Btu} / 1 \mathrm{~b})$

Sulfur: 126.04 TPD $(3,990 \mathrm{Btu} / \mathrm{lb})$ 
Table A.6. Equipment included in survey - Lurgi process

\begin{tabular}{|c|c|c|c|}
\hline \multirow[b]{2}{*}{ Identifier } & \multicolumn{2}{|c|}{ Flow rate } & \multirow[b]{2}{*}{ Unit } \\
\hline & Specified & Required & \\
\hline Pumps & $(\mathrm{gpm})$ & $(\mathrm{gpm})$ & \\
\hline LL-14 & 4,800 & 1,600 & Methanation \\
\hline MM-7 & 7,200 & $\ldots 800$ & $\begin{array}{c}\text { Tar, Tar Oil, and Naptha } \\
\text { Separation }\end{array}$ \\
\hline Compressors & $(\operatorname{acfm})$ & $(\operatorname{acfm})$ & \\
\hline $\mathrm{FB}-2$ & 260,000 & 127,000 & Flue Gas Processing \\
\hline ML-2 & 11,000 & 1,200 & Methanation \\
\hline $\mathrm{HL}-5$ & 10,000 & 7,100 & Methanation \\
\hline
\end{tabular}


ORNL-DWG 78-2428

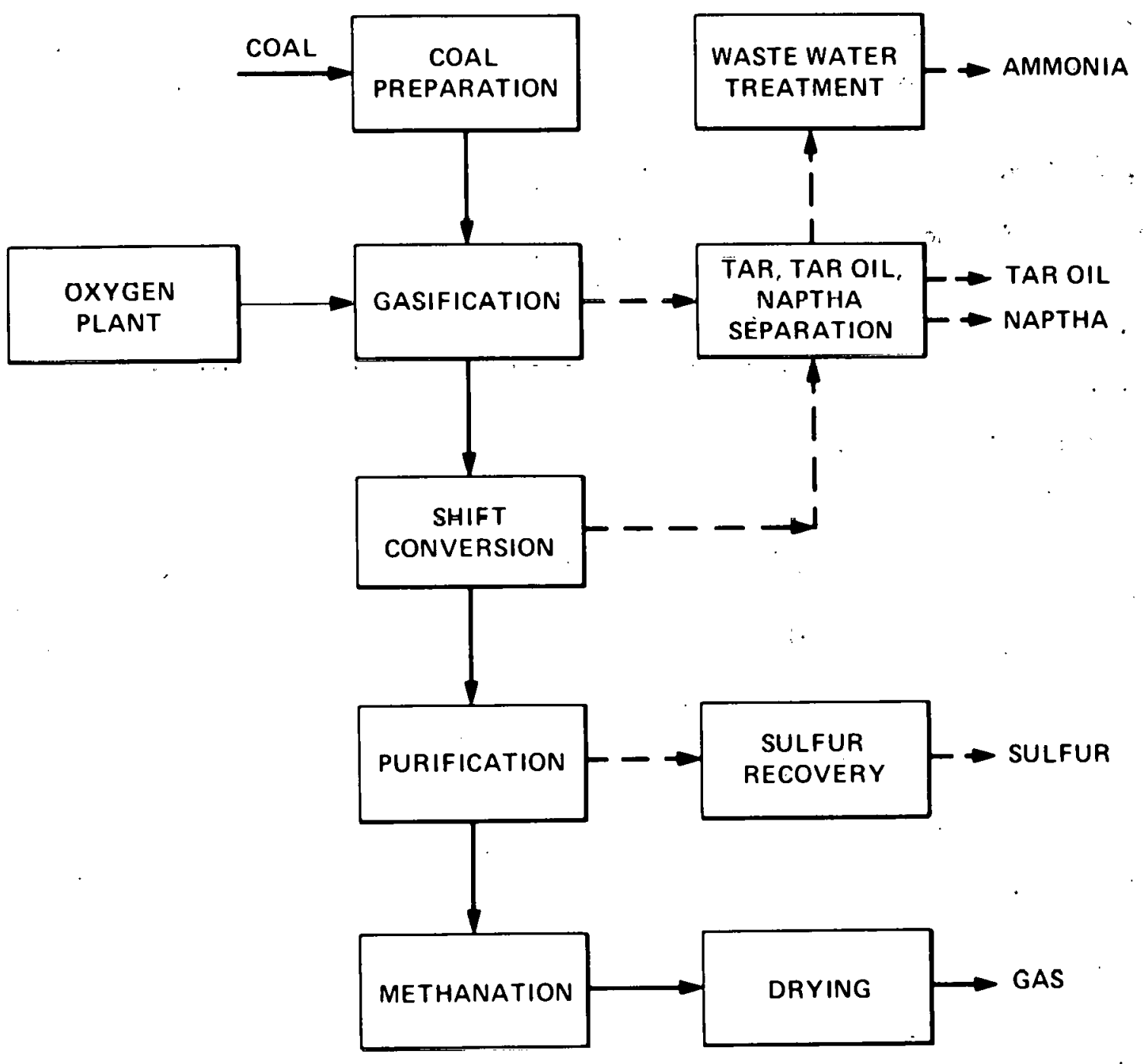

MAIN PROCESS FLOW

SECONDARY PRODUCT FLOW

Fig. A.6. Process unit flow sheet - Lurgi process. 


\section{Synthoi1 Process}

\section{Reference}

R. Salmon et a1., Evaluation of the Synthoil Process, ORNL-5209 (Draft), Oak Ridge National Laboratory (September 1976).

\section{Coal Feed}

Western Kentucky: 50,133 TPD (10,445 Btu/1b)

\section{Products}

Heavy fuel oil: $97,200 \mathrm{bbl} / \mathrm{day}(6.4 \mathrm{MM} \mathrm{Btu} / \mathrm{bbl})^{a}$

Sulfur: 2,128 ton/day $(3,990 \mathrm{Btu} / 1 \mathrm{~b})$

Ammonia: 180 ton/day $(9,800 \mathrm{Btu} / \mathrm{lb})$

a Naptha, 2,110 bbl/day; light gas oil, 665; heavy fuel oil, 94,425. 
Table A.7. Equipment included in survey - Synthoil process

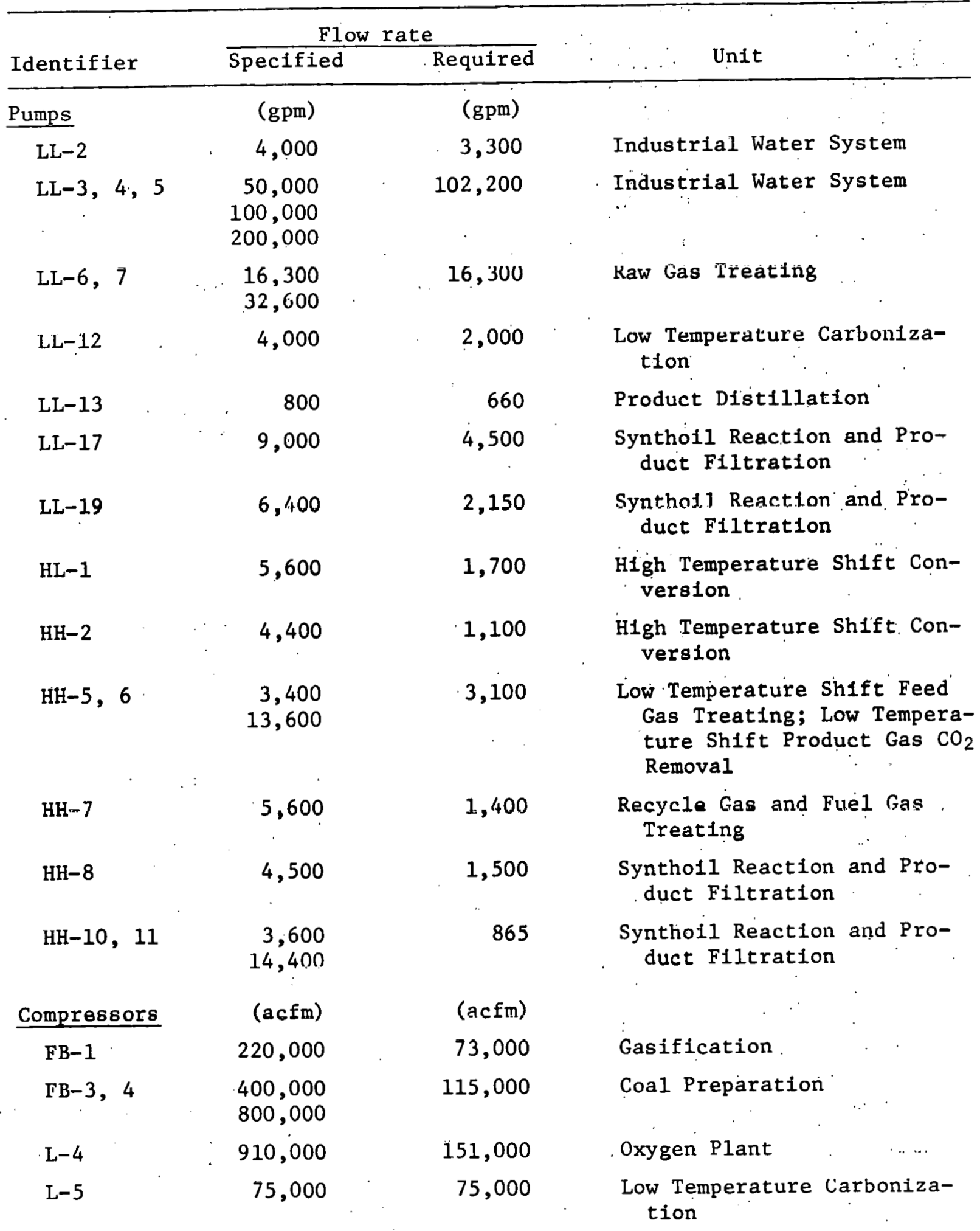


Table A.7' (continued)

\begin{tabular}{|c|c|c|c|}
\hline \multirow[b]{2}{*}{ Identifier } & \multicolumn{2}{|c|}{ Flow rate } & \multirow{2}{*}{$\because \quad \cdots \quad \therefore$ Unit } \\
\hline & Specified & Required & \\
\hline Compressors & $(\operatorname{acfm})$ & $(\operatorname{acfm})$ & : \\
\hline$M L-4,5,6$ & $\begin{array}{l}150,000 \\
300,000 \\
900,000\end{array}$ & 30,000 & $\begin{array}{l}\text { Oxygen Plant } \\
\vdots\end{array}$ \\
\hline $\mathrm{MH}-3$ & 16,000 & 8,000 & Gasification \\
\hline $\mathrm{HH}-3$ & 30,000 & 28,000 & $\begin{array}{l}\text { High Temperature Shift Con- } \\
\text { version }\end{array}$ \\
\hline $\mathrm{VH}-1$ & 7,000 & 6,300 & $\begin{array}{l}\text { Synthoil Reaction and Pro- } \\
\text { duct Filtration }\end{array}$ \\
\hline $\mathrm{VH}-4,5$ & $\begin{array}{r}7,000 \\
28,000\end{array}$ & 6,600 & $\begin{array}{l}\text { Synthoil Reaction and Pro- } \\
\text { duct Filtration }\end{array}$ \\
\hline \multicolumn{4}{|c|}{ Hydraulic turbines } \\
\hline . & (gpm) & $(\mathrm{gpm})$ & \\
\hline $\mathrm{T}-4,5$ & $\begin{array}{l}1,296 \\
5,182\end{array}$ & . & $\begin{array}{l}\text { Recycle Gas and Fuel Gas } \\
\text { Treating }\end{array}$ \\
\hline $\mathrm{T}-6,7$ & $\begin{array}{l}1,467 \\
5,870\end{array}$ & & $\begin{array}{l}\text { Low Temperature Shift Feed } \\
\text { Gas Treating }\end{array}$ \\
\hline $\mathrm{T}-8,9,10$ & $\begin{array}{r}3,126 \\
12,506 \\
25,012\end{array}$ & & $\begin{array}{l}\text { Low Temperature Shift Feed } \\
\text { Gas Treating }\end{array}$ \\
\hline $\begin{array}{c}\mathrm{T}-11,12 \\
\vdots\end{array}$ & $\begin{array}{r}7,750 \\
31,000\end{array}$ & & Raw Gas Treating \\
\hline $\mathrm{T}-13$ & 404 & 101 & $\begin{array}{l}\text { Synthoil Reaction and Pro- } \\
\text { duct Filtration }\end{array}$ \\
\hline $\begin{array}{c}\mathrm{T}-14,15,16 \\
17\end{array}$ & $\begin{array}{r}1,428 \\
4,284 \\
8,567 \\
17,134\end{array}$ & 1,428 & $\begin{array}{l}\text { Synthoil Reaction and Pro- } \\
\text { duct Filtration }\end{array}$ \\
\hline $\mathrm{T}-20,21,22$ & $\begin{array}{r}1,042 \\
4,170 \\
16,680\end{array}$ & & $\begin{array}{l}\text { Synthoil Reaction and Pro- } \\
\text { duct Filtration }\end{array}$ \\
\hline $\mathrm{T}-23,24$ & $\begin{array}{r}4,124 \\
16,497\end{array}$ & & $\begin{array}{l}\text { Synthoil Reaction aud Piu- } \\
\text { duct Filtration }\end{array}$ \\
\hline
\end{tabular}


ORNL-DWG 78.2429

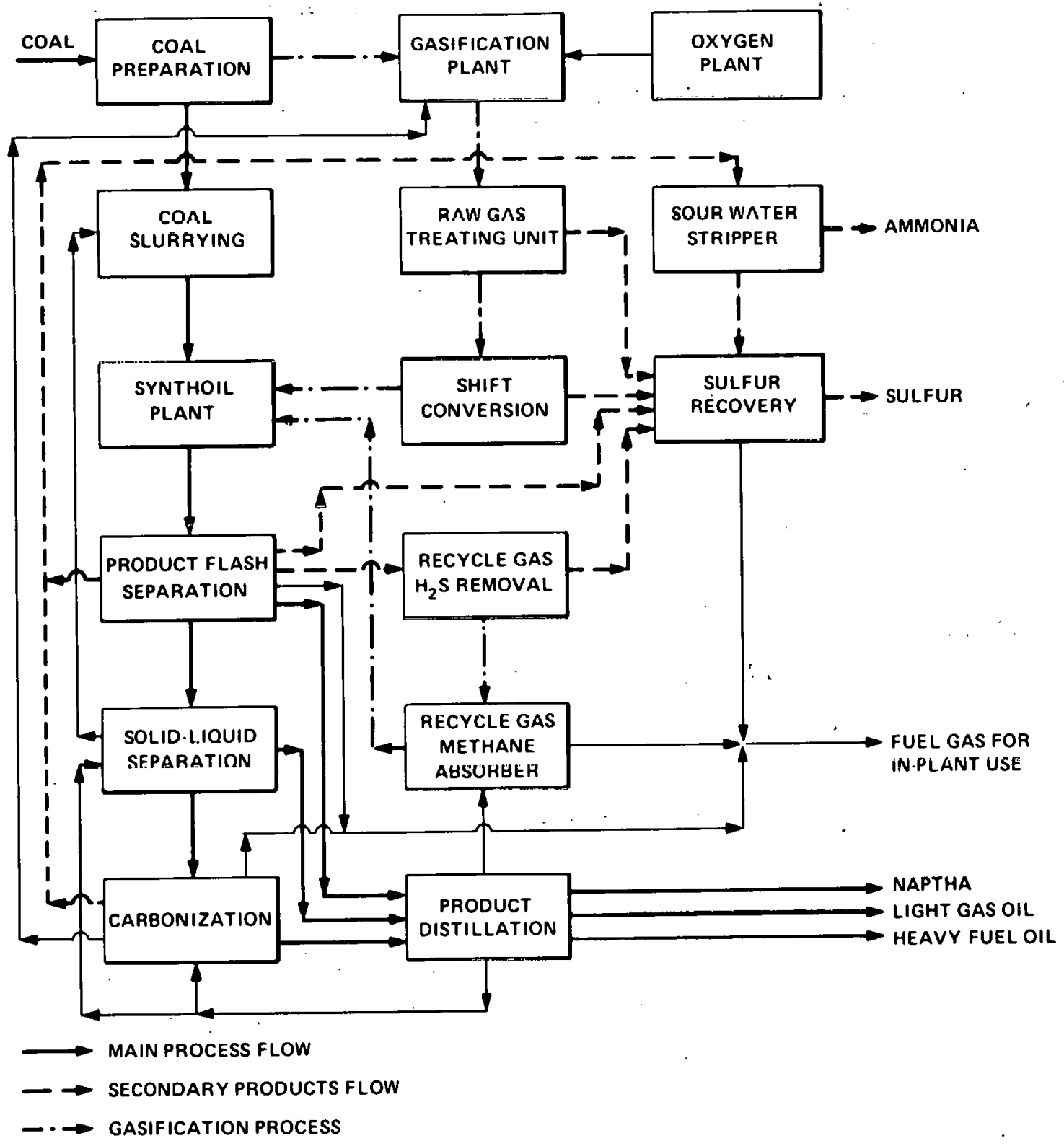

Fig. A.7. Process unit flow sheet - Synthoil process. 


\section{Supplemental Sources}

Two additional conceptual design reports were reviewed for hydraulicturbine and gas-expander applications. Information on these sources is provided below. Information was also obtained from Stearns-Roger concerning expanders for the $\mathrm{CO}_{2}$ Acceptor process.

\section{$\mathrm{CO}_{2}$ Acceptor Process}

\section{Reference}

Personal communication to authors from Stearns-Roger personnel during visit in Denver, Colo., on Apr. 27, 1977.

\section{HYGAS Process}

\section{Reference}

Institute of Gas Technology, HYGAS: 1964 to 1974, Pipeline Gas from Coal Hydrogenation (IGT Hydrogasification Process), FE-381-T9-P4, vol. 4, part 8, Chicago, I11. (July 1975).

\section{HYGAS (Steam-Iron) Process}

\section{Reference}

R. Detman, Factored Estimates for Western Coal Commercial Concepts, Technical Appendix II, FE-2240-5, IR, App. I, C. F. Braun and Company, Alhambra, Calif. (October 1976). 
Table A.8. Equipment included in survey - Supplemental sources

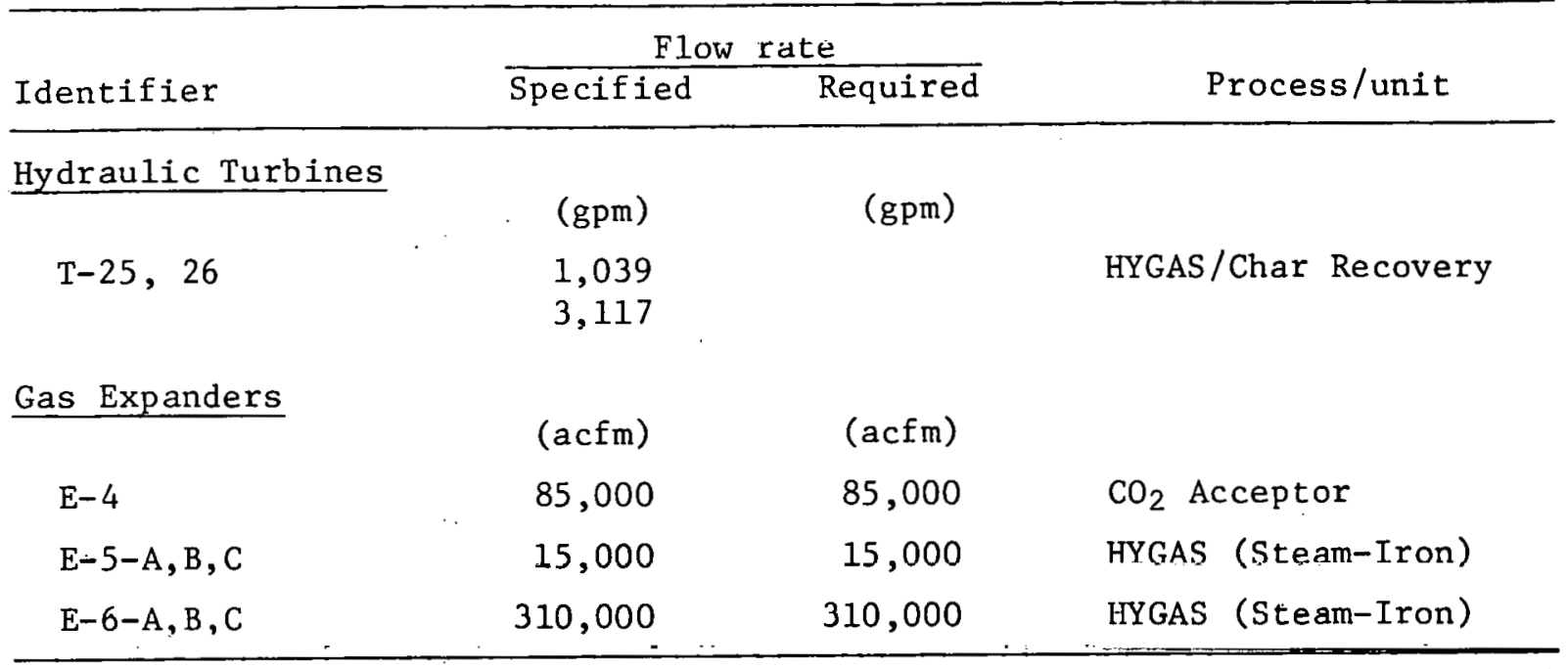


$\therefore$ Appendix B

QUESTIONNAIRES 
Appendix B

QUESTIONNAIRES

Four questionnaires, one each on pumps, compressors, hydraulic turbines, and gas expanders, were prepared and sent to industry. These questionnaires and their cover letter comprise this appendix. Crossreference listings giving the processes and required flow rates of equipment which serve as models for equipment specifications shown in these questionnaires may be found in Appendix C. Additional information on equipment location within the processes is available by consulting Appendix A, once the process is determined.

The following errata were noted in the questionnaires after they had been sent to industry.

1. Pumps, page 6 of 10

LL-3, correct horsepower, 1459 hp

LL-4, correct horsepower, 2917 hp

LL-5, correct horsepower, $5834 \mathrm{hp}$

LL-21, correct horsepower, $357 \mathrm{hp}$

LL-22, correct horsepower, $126 \mathrm{hp}$

2. Pumps, page 7 of 10

ML-5, correct pressure head, 74 psi

3. Pumps, page 8 of 10

MM-7, correct horsepower, $1890 \mathrm{hp}$

4. Compressors, page 7 of 8

ML-4 through ML-6. Divide flow rate and. horsepower by 32 to obtain correct values; correct inlet pressure is about 15 psia.

5. Compressors, page 8 of 8

VH-3, correct molecular weight, $5.6 \mathrm{lb} / 1 \mathrm{~b}$ mole

6. Gas Expanders, page 6 of 6

E-1, correct composition, $79 \% \mathrm{H}_{2}, 19 \% \mathrm{CH}_{4}, 2 \% \dot{\mathrm{C}}_{2} \mathrm{H}_{6}$ 


\section{UNION}

\section{GARBIDE}

\section{UNION CARBIDE CORPORATION}

\section{NUCLEAR DIVISION}

P.O. BOX X, OAK RIDGE, TENNESSEE 37830

Date

Company Name

and

COVER LETTER INTRODUCING

Address

Gentlemen:

Investigation of Industrial Coal Conversion Equipment Capability

An Investigation of United States industry's ability to provide rotating equipment for coal conversion facilities of demonstration and commercial scale is being performed at the Oak Ridge National Laboratory by Union Carbide Nuclear Division. This work is being sponsored by the United States Energy Research and Development Administration/Fossil Energy, Major Facilities Project Management Division. Industry input is desired in two areas:

1. defining the present capability of industry to supply the equipment needed;

2. determining research and development needs, including lead time requirements, for producing equipment of advanced design.

Appreciation is expressed to those firms who have responded to our request for information article in the Commerce Business Daily of January 28, 1977. The attached package represents our next activity in this study.

The study deals with fluid transport and power recovery devices for handiling air, liquids, o1ls, gases, and slurries in coal conversion plants. Equipment of interest includes turbines, expanders, pumps, compressors, and associated drive trains.

Would you please help us by providing information on the following specific equilipiment.

Pumps and Associated Drive Trains Compressors and Associated Drive Trains Hydraulic Turbines and Associated Drive Trains Gas Expanders and Associated Drive Trains
Only lines applicable to the manufacturer were listed. 
This is not a request for proposal; nor may it serve as a basis for any claim for relmbursement of costs for efforts expended. It is likely, however, that this study will directly benefit the rotating equipment industry as well as the Government and the public. The names of the participating companies, as well as their addresses, will be listed in the final report along with the answers supplied to Questions 1 and 2 . Other Information supplied will be published on a statistical bas ls only. A copy of the final report will be sent directly to the responding firms. The report summarlzing this study will be avallable to the public through normal Government publication channels. Therefore, please do not supply any propitetary information; such information will not be accepted.

An attachment, including an objective questlonnatre, has been developed for each spectflc type of equipment 1isted above. We hope that this will help you provide the necessary information with a minimum of time and effort. Two copies of each attachment are enclosed, one to keep for your information and one for your response. We would appreciate receiving your input in the format of the questionnaire. We are hoping to accumulate the data by response date. Your cooperation in meeting this date would be most helpful.

Your ideas or suggestions which may help in making this investigation more beneficial to both governmental and industrial planners are welcomed. If additional information or clarification is needed, please call me collect at (615) 483-8611, ext. 3-0172 or W. Reid Williams at ext. 3-0321.

Your help in this effort is appreclated.

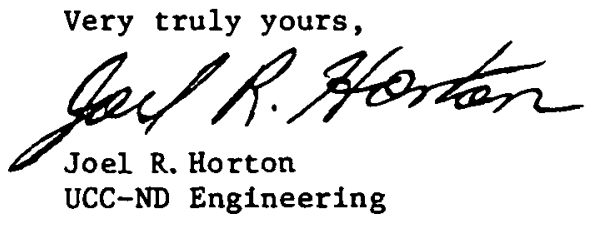

JRH:blm

Attachment: Pumps

Compressors

Hydraulic Turbines

As appropriate

Gas Expanders 


\section{ATTACHMENT \\ Investigation of Coal Conversion Equipment Capability}

Pump8

This attachment includes a list of typical applications for pumps in proposed coal conversion plants and a questionnalre for determining the avallabllity of pumps for these applications.

Sheets 2 and 3 of this attachment list general instructions for completing the questionnaire.

Sheet 4 11sts the availability code to use in completing item 1 of the instructions.

Sheet 5 is an address and reference form which should be completed to properly reference your firm and point of contact. One individual should be named on this form for further contact by telephone during this study if necessary.

Sheets $6,7,8,9$, and 10 list the typlcal applications for pumps in coal conversion plants and provide blank columns for inserting the information requested by this questionnalre.

We recognize, that some of the questions may be too difficult or time consuming to answer. We will appreclate your effort in answering these questions to the extent possible. 
GENERAL INSTRUCTIONS

\section{Pump Ava1lability}

Please choose the most appropriate avallability code from the list on sheet 4 and insert it in column 1.

2. Largest Ava1lable Capac1ty

Please indlcate in column 2 the largest capacity pump which you do make for the process conditions listed.

3. Limiting Factors

If your availability code In column 1 is not A1 or A2, please indicate the particular characteristics which are the limiting factors: Expand on this with additional sheets, if necessary, and refeferlce footnotes

in column 3.

Please answer the remalning questions based on the larger of the capacities listed in columns 2 and $B$.

4. Type of Pump for Each Application

Please Indicate in column 4 the recommended type of pump for the specified service: piston, plunger, diaphragm, blow case, rotary, centrifugal, peripheral, or other:

5. Stages

Please insert in column 5 the estimated number of stages.

6. Recommended Driver

Please indicate the recomended driver by inserting the appropriate code in column 6 from the following list.
A. Electric motor
E. Hydraulic turbinè
B. Steam turbine
F. Steam (reciprocating)
C. Gas turbine
G. Other
D. Gas expander

7. Recommended Intermediate Transmission

Please indicate the recommended intermediate transmission by inserting the appropriate code in column 7 from the following list.
A. Direct-drive, common-shaft
B. Direct-drive, coupled-shaft
C. Speed - increasing gear
D. Speed - reducing gear
E. Other (Please Indicace with footnote.)

\section{Catalogs}

Please provide two copies of catalogs on your pump equipment for the following:

a. pumps for the more difficult applications;

b. the most advanced line of pumps presently manufactured by your cumpany.

Catalog numbers and/or other identifying information may be added in column 8 . 
9. Anticipated Maintenance Cost

Please consider the average annual repair and maintenance cost during the first ten years of the life of the pump when used in the service indicated. Please insert in column 9 the number which best represents your estimate of the average annual maintenance cost as a percentage of the initial cost of the pump: $<5 \%,<10 \%,<25 \%,<50 \%,<100 \%$, or $>100 \%$.

10. Projected In-Service Avallability

Please provide in column 10 your projection of avallable in-service time: $98 \%+, 95 \%+, 80 \%+, 60 \%+,<60 \%$.

\section{Problem Areas}

For the equipment specified for this application, please identify the most severe problems ant.fripated by inserting the most appropriate code(s) in column 11 from the following list.
A. Corrosion
H. Seals
B. Erosion
C. Pitting
D. Deposits
E. Plugging
F. Bearings
G. Cavitation
I. Couplings
J. Vibration
k. Drivers
L. Intermediate Transmissions
M. Other

12. Delivery Time

For equipment which you make or anticlpate mak 1ng, please Insert in column 12 the number below which best represents the anticipated lead time in months required from order placement through installation and check out: $<6,<12,<18,<24,<36$, or $>36$. (Dellvery time does not include development time which should be included in item 13.)

13. Development Lead Time

For equipment not yet avallable but specifled for applications 11sted, please state the total anticlpated time for research, development, and testing required to provide the first unit of rellable equipment. Please state in years in column 13.

14. Additional Comments

Additional comments on specific applications are welcomed. These may be stated or footnoted in column 14. Attach additional sheets, if necessary.

15. Industry Capab1lities and Quant1t1es

rlease proulde yuur gelletal cuurnenty and your assessment of Indusery's capability to supply pumps of advanced design in sufficient quantities for demonstration and commercial coal conversion plants. This is assuming that coal conversion w1ll become a major industry within the next ten to fifteen years. 
AVAILABILITY CODES FOR USE IN COMPLETING ITEM 1

Ava1lable Equ1pment

Available off-the-shelf equipment produced by our company.

Equipment available by special order through our company.

Equipment not presently avallable through our company but belleved to be avallable within the industry.

\section{Technology Available for Scale-up}

Equipment is not presently avallable through our company but technology is available in-house which will likely be used if market forces are attractive.

B2

Equipment is not presently avallable through our company but technology is avallable within the industry which will likely be used by one or more companies if market forces are attractive.

\section{Anticipated Technology by 1982}

Anticipated technology requiring R\&D which will 11ke1y be funded by our company if market forces are attractive.

Anticipated tecluivlogy requiring K\&D which can be funded by industry if market forces are atcractive.

Anticipated technology requiring R\&D which can be handled through our company provided governmental assistance 1 s available.

Anticipated technology requiring R\&D which can be handled within the industry provided governmental assistance is avallable.

\section{Anticlpaced Technology: 1982 to 1987}

Very advanced future technology requiring extensive R\&D which is likely to be handled by industry by 1987 without governmental assistance.

Very advanced future technology requiring extensive R\&D which requires governmental assistance for development by 1987 .

\section{Questionable Technology}

Technology not believed posslble before 1987

Technology not belleved possible fur these conditions.

\section{Inapplicable}

F1

None of the above codes are applicable or approprlate for our f1rm to use. Insert a footnote in column 14 for additional comments, if so desired. 


\section{B-9}

Pumps

To: Joel R. Horton

Union Carbide Corporation-

Nuctear Division

MS $241-A, B 1 d g .1000$

Post Office Box $X$

Oak RIdge, TN 37830

\section{Investigation of Industrial Coal Conversion Equipment Capability \\ Address and Reference Form for Manufacturers

$$
\text { of }
$$ \\ Pumps}

1. Please indicate below the name und address of your company as you would like to have it listed in the final report.

COMPANY

AND

DIVISION

STREET

CITY ZIP

2. Please indicate below an individual's nume and address avallable for additional communtcation, if necessary, during the period of this study.

NAME

COMPANY

AND

DIVISION

STREET

CITY

STATE

ZIP

3. Please Indicate below the name and address of a person (or posttion) you would like to have the final report malled to.

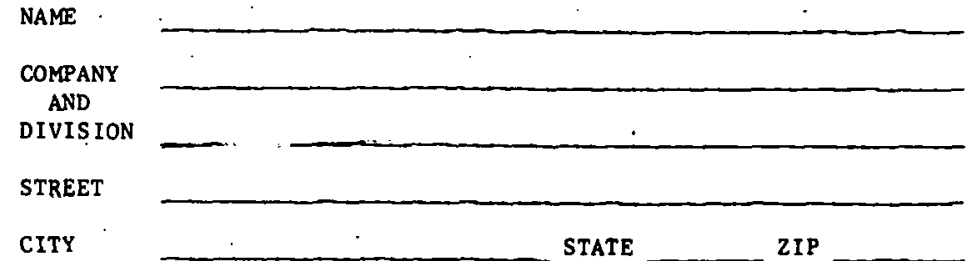

Respectfully submitced,

Date

Please return this sheet together with sheets $6,7,8,9$, and 10 of this attachment for pumps. 


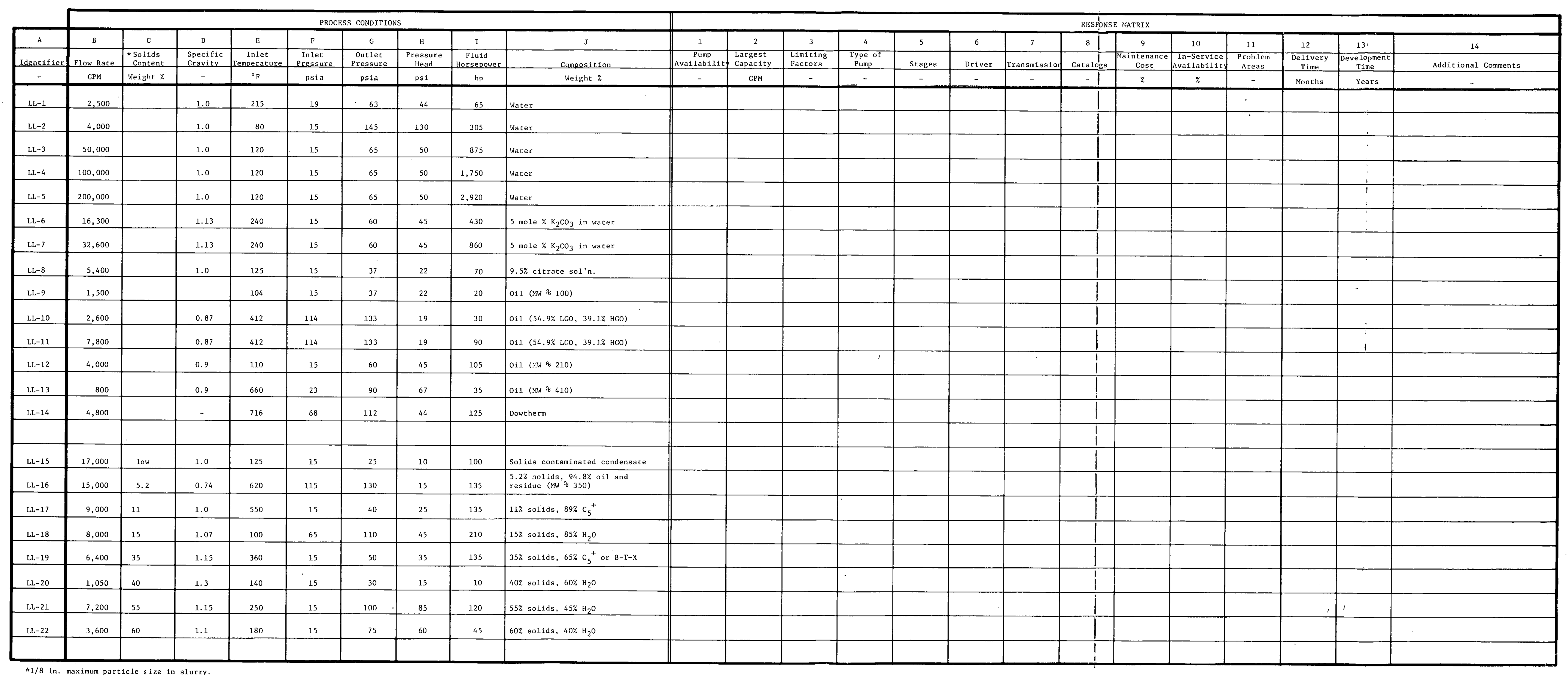




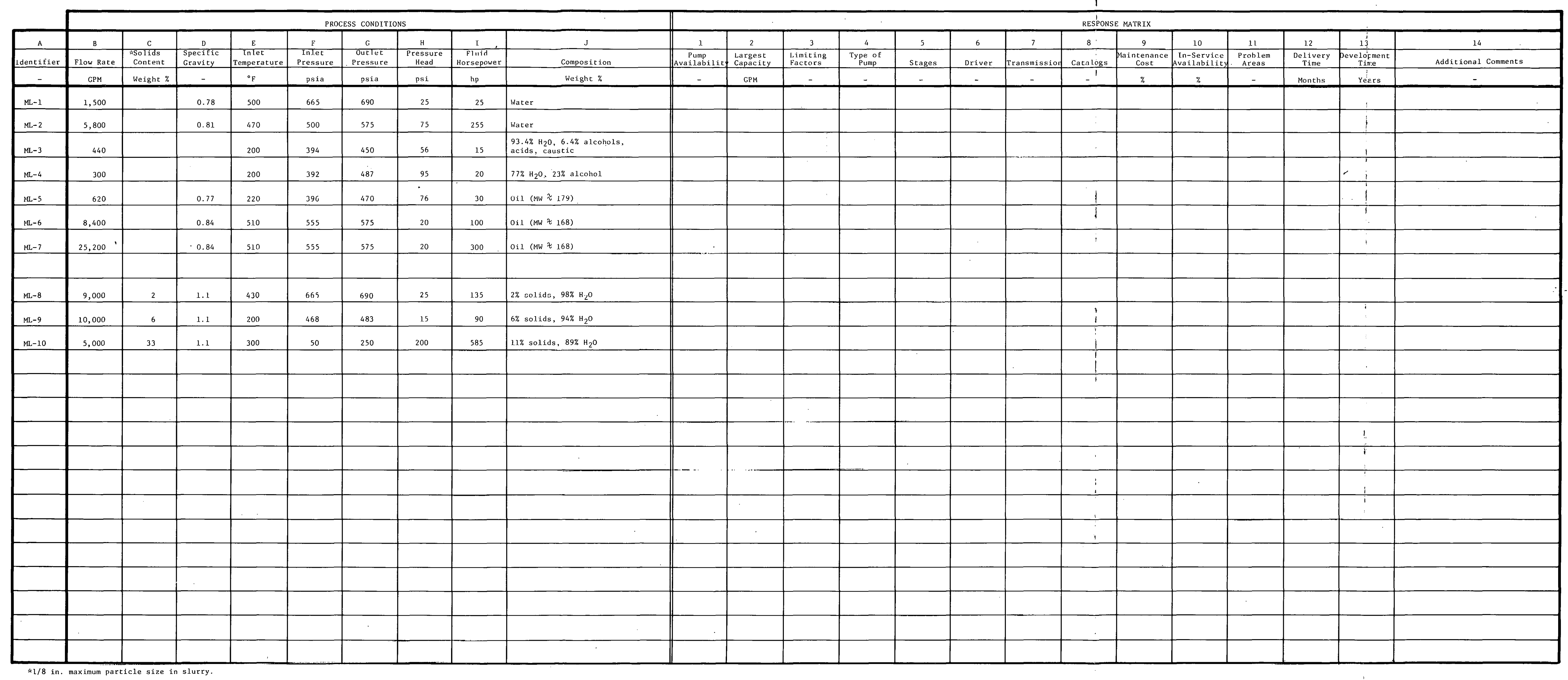














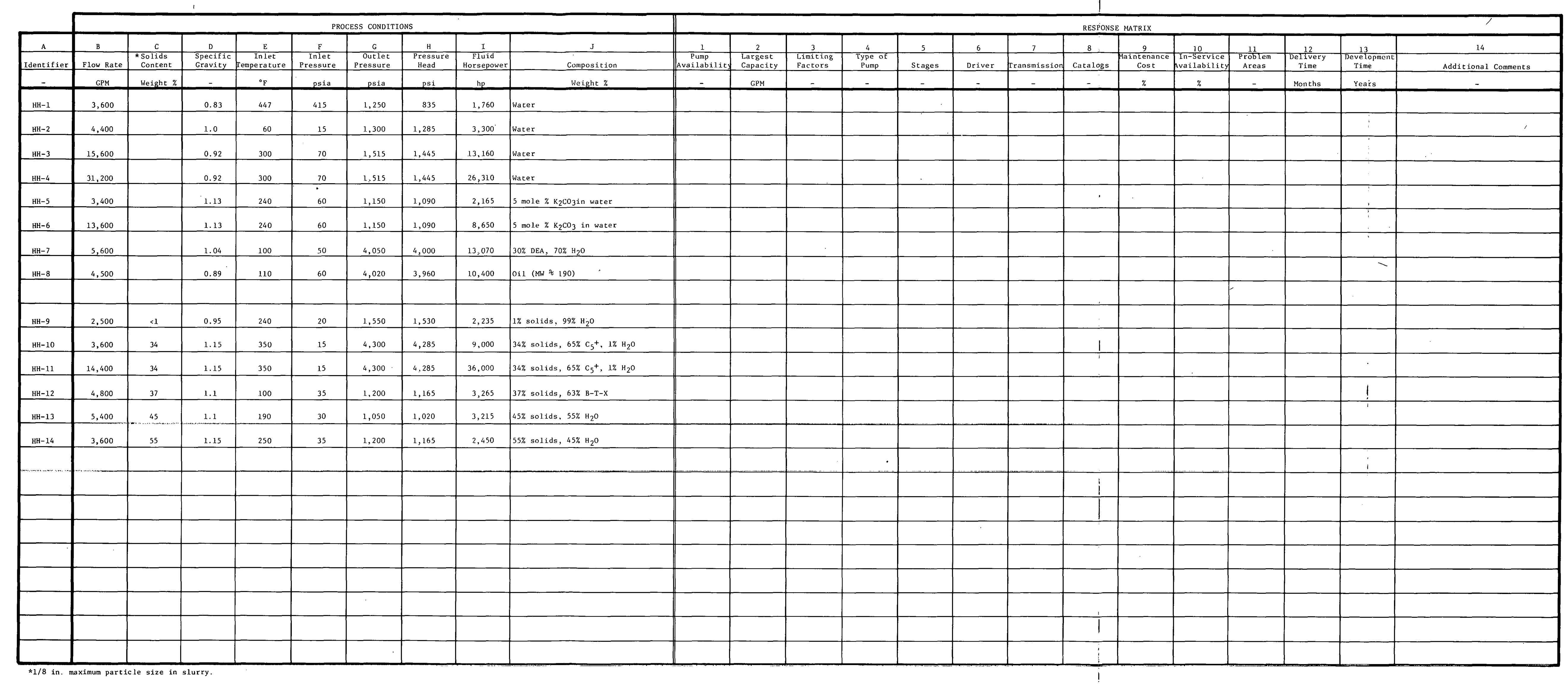




\section{ATTACHMENT}

\section{Investigation of Coal Conversion Equipment Capability}

\section{Compressors}

This attachment includes a list of typical applications for compressors in proposed coal conversion plants and a questionnaire for determining the availability of compressors for these applications.

Sheets 2 and 3 of this attachment list general inslructions for completing the questionnaire.

Sheet 4 lists the availability code to use in completing item 1 of the instructions.

Sheet 5 is an address and reference form which should be completed to properly reference your firm and point of contact. One individual should be named on this form for further contact by telephone during this study if necessary.

Sheets 6, 7, and 8 list the typical applications for compressors in coal conversion plants and provide blank columns for inserting the information requested by this questionnaire.

We recognize that some of the questions may be too difficult or time comsuming to answer. We will appreciate your effort in answering these questions to the extent possible.

NOTE: The isothermal horsepower in column $I$ is expressed as ideal. It is realized that few, if any, compressors will operate under isothermal conditions. This quantity is simply a measure of the minimum horsepower under ideal conditions. 
GENERAL INSTRUCTIONS

1. Compressor Ava1lability

Please choose the most appropriate avallability code from the list on sheet 4 and insert it in column 1 .

2. Largest Avallable Capacity

Please indicate in colum 2 the largest capacity compressor which you do make for the process conditions listed.

3. Limiting Factors

If your avallability code in column 1 is not A1 or A2, please indicate the particular characteristics which are the limiting factors. Expand on this with additional sheets, if necessary, and reference fontinotes In column 3 .

Please answer the remaining questlons based on the larger of the capacities listed in columns 2 and B.

4. Type of Compressor for Each Application

Please indicate in colum 4 the recommended type of compressor for the specified service.
A. Reciprocating
F. Centrifugal
B. Sliding vane
C. Straight lobe
D. Helical lobe
E. Liquid piston
H. Mixed flow
I. Other

5. Siages

Please insert in column 5 the estimated number of stages.

6. Rccommended Driver:

Please indicate the recommended driver by inserting the appropriate code in column 6 from the following list. Assume that any of the below is available.
A. Electric motor
B. Steam turbine
E. Hydraulic turbine
C. Gas turbine
F. Steam (reciprocating)
v. Gas expander
G. Other

7. Recommended Intermediate Transmission

Please indicare the rocomended interiuedlate Lransmission by inserting the appropriate code in column 7 from the following l1st,
A. Direct-drive, common-shaft
B. Direct-drive, coupled-shaft
C. Speed - increasing gear
D. Speed - reducing gear
E. Other (Please indicate with footnote.)

8. Catalogs

Please provide two coples of catalogs on your compressor equipment for the following:

a. compressors for the more difficult applicationo;

b. the most advanced line of compressors presently manufactured by your company.

Catalog numbers and/or other identifying information may he added in column 8 . 


\section{Ant1c1pated Maintenance Cost}

Please consider the average annual repalr and maintenance cost during the first ten years of the life of the compressor when used in the service indicated. Please insert in colum 9 the number which best represents your estimate of the average annual maintenance cost as a percentage of the initial cost of the compressor: $<5 \%,<10 \%,<25 \%,<50 \%$, $<100 \%$, or $>100 \%$.

\section{Projected In-Service Availabiltty}

Please provide in column 10 your projection of avallable in-serivce time: $98 \%+, 95 \%+, 80 \%+, 60 \%+,<60 \%$.

11. Problem Areas

For the equipment specified for this application, please identify the most severe problems anticipated by inserting the most appropriate code(s) in column 11 from the following list.
A. Corrosion
H. Gas cleaning
B. Erosion
I. Couplings
C. Pitting
K. Drivers
E. Ylugging
F. Bearings
L. Intermed
M. Other

G. Seals

12. Delivery Time

For equipment which you make or anticipate making, please insert in column 12 the number beluw which best represents the anticipated lead time in months required from order placement through installation and check out: $<6,<12,<18,<24,<36$, or $>36$. (Delivery time does not include development time which should be included in item 13.)

13. Development Lead Time

For equipment not yet available but specified for applications listed, please state the total anticipated time for research, development, and testing required to provide the first unit of rellable equipment. Please state in years in column 13.

14. Additional Comments

An indication of limits un particulate loading would be appreciated. Other comments on speciftc applications are welcomed. These may be stated or footnoted in column 14. Attach additional sheets, if necessary.

1.5. Industry Capabllities and Quantities

Please provide your general comments and your assessment of industry's capability to supply coupressors of advanced design in sufficient. quantities for demonstration and commercial coal conversion plants. This is assuming that coal conversion will become a major industry within the next ten to fifteen years. 
AVAILABILITY CODES FOR USE IN COMPLETING ITEM 1

\title{
Ava1lable Equipment
}

Al

(1)

Avallable off-the-shelf equipment produced by our company.

Equipment available by special order through our company.

Equipment not presently available through our company but believed to be available within the industry.

Technology Available for Scale-up

Equipment is not presently available through our company but technology is available in-house which will likely be used if market forces are attractive.

Equipment is not presently avallable through our cumpany but rechnology is available within the industry which will likely. be used by one or more companies if market forces are attractive.

Anticipated Technology by 1982

Anticipated technology requiring R\&D which will likely be funded by our company if market forces are attractive.

Anticipated technology requiring $R \& D$ which can be funded by industry if market forres ara attractive.

Anticipated technology requiring R\&D which can be handled , thruugh our company provided governmental assistance is available.

Anticipated technology requiring R\&D which can be handled within the industry provided governmental assistance is avallable.

Anticipated Technology: 1982 to 1987

Very advanced future technology requiring extensive R\&D which is likely to be handled by industry by 1987 without governmental assistance.

Very advanced future technology requiring extensive R\&D which requires governmental assistance for development by 1987.

\section{Questionable Technology}

\author{
Technology not believed possible before 1987.
}

Technology not bolieved possible for these conditions.

\section{Inapplicable}

None of the above codes are applicable or appropriate for our $\mathrm{f} 1 \mathrm{rm}$ to use. Insert a footnote in column 14 for additional coments, if so desired. 
To: Joel R. Horton

Union Carbide Corporation-

Nuclear Division

MS 241-A, B1dg. 1000

Post office Box $X$

Oak Ridge, TN 37830

Investigation of Industrial Coal Conversion

Equipment Capability

Address and Reference Form for Manufacturers

of

Compressors

1. Please Indicate helow the name and address of your company as you would like to have it listed in the final report.

\section{COMPANY \\ AND \\ DIVISION}

STREET

CITY

STATE 2IP

2. Please indicate below an individual's name and address avallable for additional communication, if necessary, during the perfod of this study.

NAME

COMPANY

AND

DIVISION

STREET

CITY

STATE

2IP

3. Please indicate below the name and address of a person (or position) you would like to have the final report mailed to.

NAME

COMPANY

AND

DIVISION

STREET

CITY

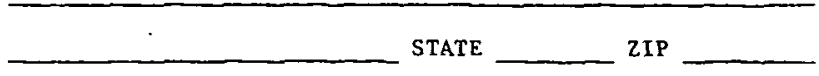

Respectfully submitted,

Date

Please return this sheet together with sheets 6,7 , and 8 of this at tachment for compressors. 


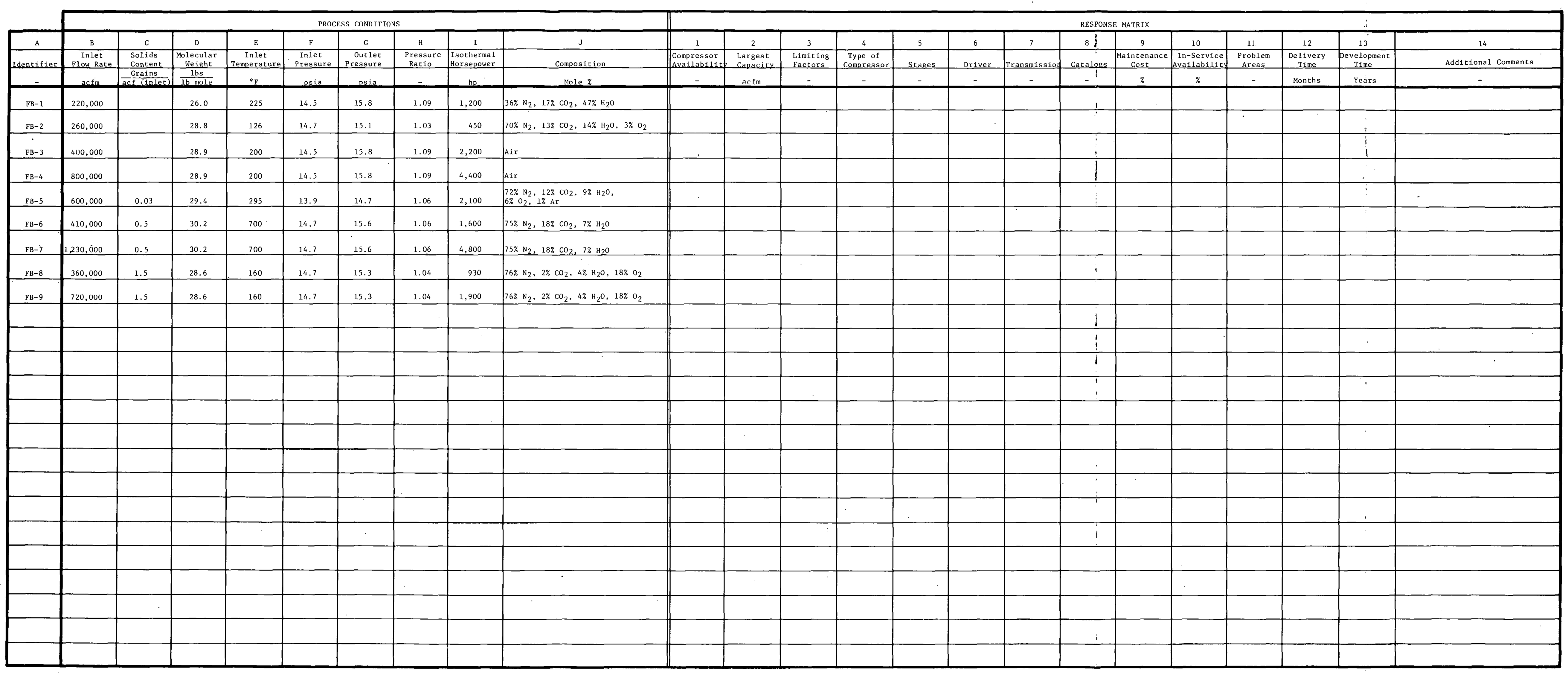




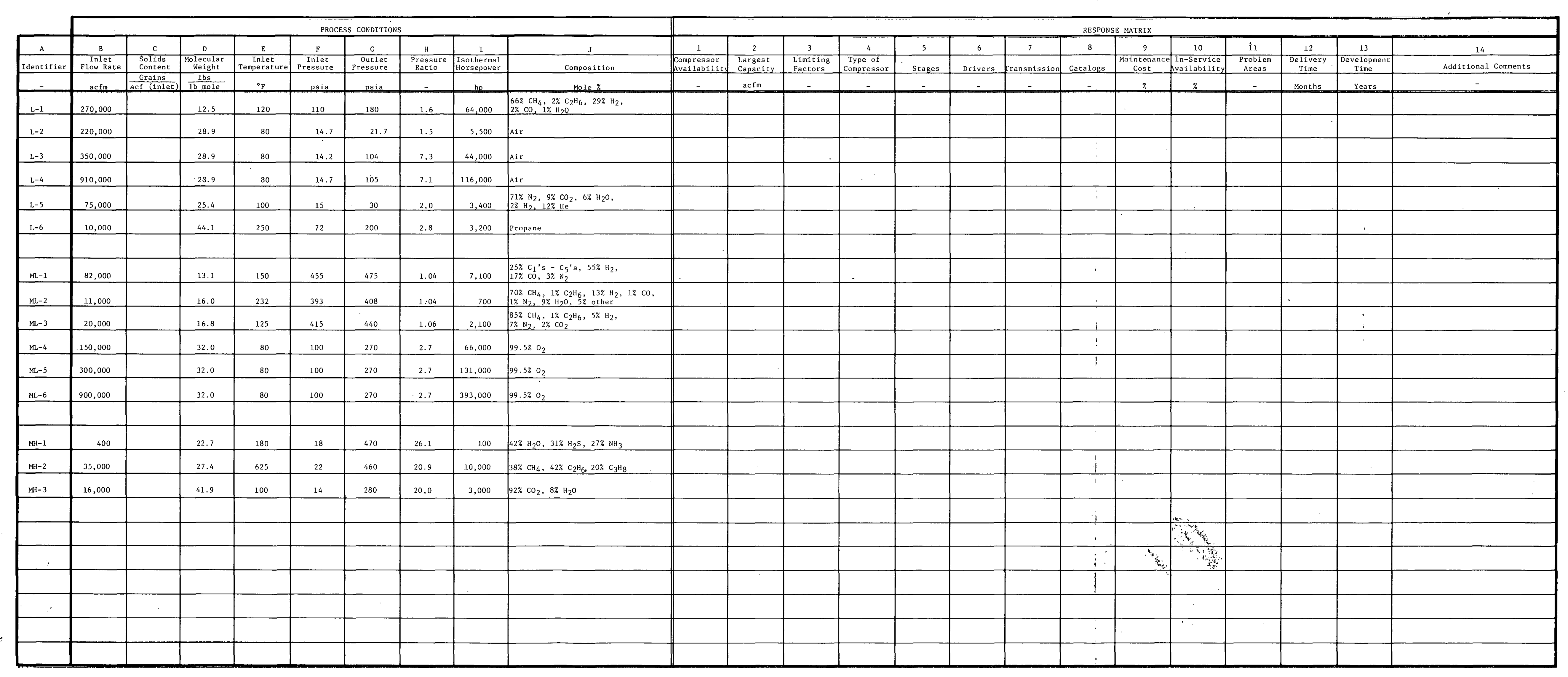




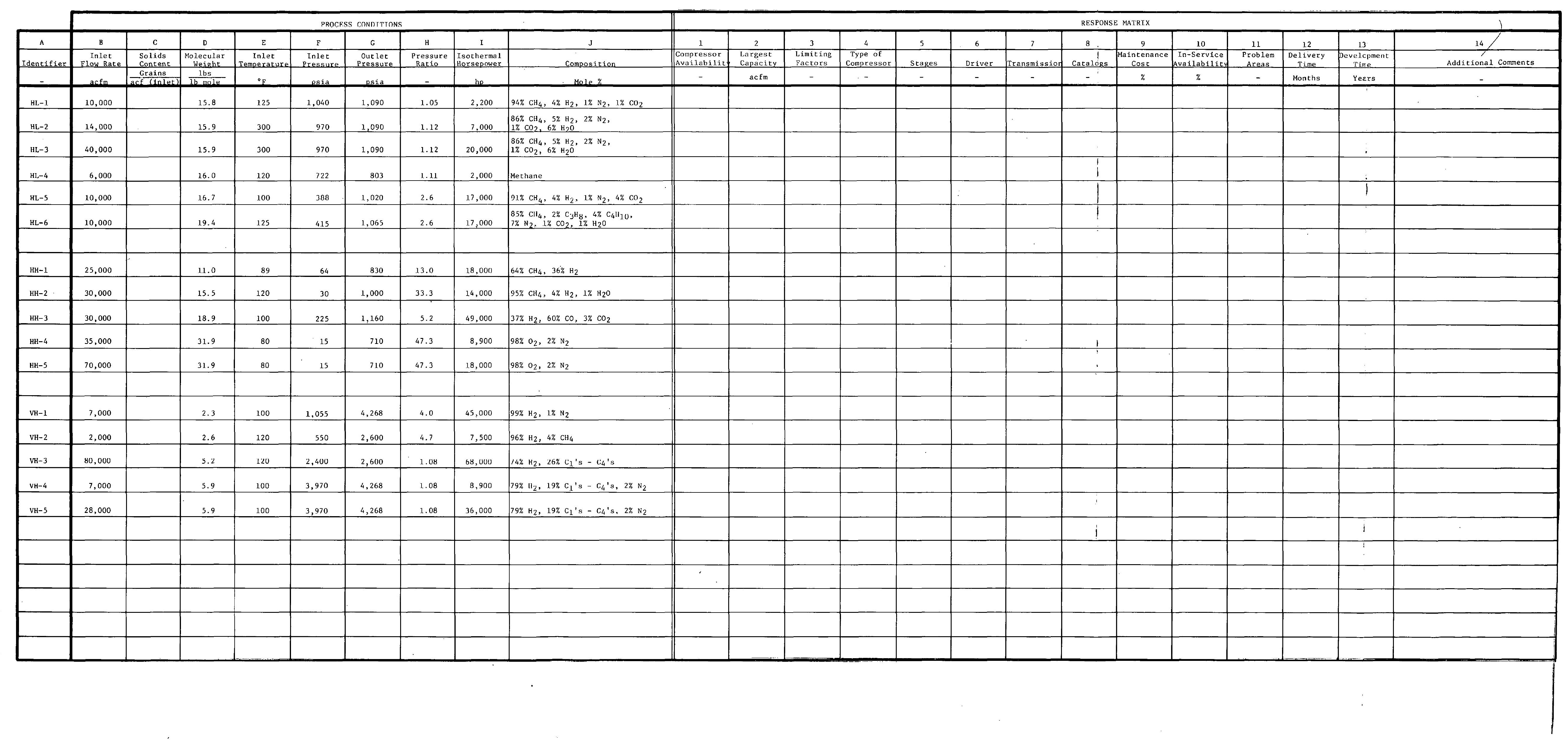


ATTACHMENT

Investigation of Coal Conversion Equipment Capability

\section{Hydraulic Turbines}

This attachment includes a list of typical applications for hydraulic turbines in proposed coal conversion plants and a questionnaire for determining the availability of hydraulic turbines for these applications.

Shepts 2,3 , and 4 of this attachment list general instructions for completing the questionnaire.

Sheet 5 lists the availability code to use in completing item 1 of the instructions.

Sheet 6 is an address and reference form which should be compieted to properly reference your firm and point of contact. One individual should be named on this form for further contact by telephone during this study if necessary.

Sheet 7 lists the typical applications for hydraulic turbines in coal conversion plants and provides blank columns for inserting the information requested by this questionnaire.

We recognize that some of the questions may be too difficult or time consuming to answer. We will appreciate your effort in answering these questions to the extent possible.

NOTE: The fluid horsepowers appearing in columns $I$ and $L$ are expressed as ideal. It is realized that $f e w$, if any, hydraulic turbines or pumps will operate under ideal conditions. The quantity in column I is simply a measure of the maximum horsepower available to the hydraulic turbine under ideal conditions, while the quantity in column $L$ is the minimum required by the pump. 
GENERAL INSTRUCTIONS

1. Turbine Availability

Please choose the most appropriate availability code from the list on sheet 5 and insert it in column 1 .

2. Largest Available Capacity

Please indicate in column 2 the largest capacity turbine which you do make for the process conditions listed.

3. Limiting Factors

If your availability code in columin 1 is not Al or A2, please indicate the particular characteristics which are the limiting factors. Expand on this with additional sheets, if necessary, and reference footnotes in column 3 .

4. Type of Turbine for Each Application

Please indicate in column 4 the recommended type of unit for the specified service.

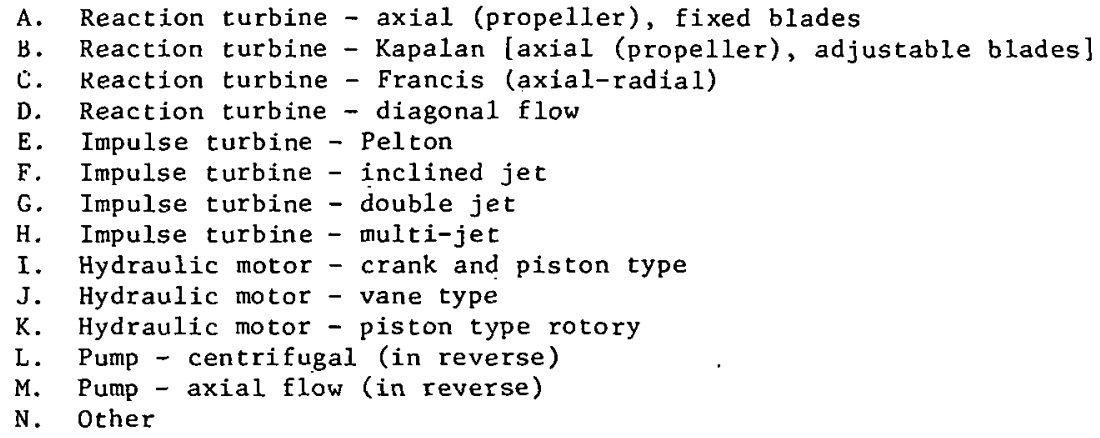

5. Stages

Please insert in column 5 the estimated number of stages.

6. Load and Speed Contro1

Please indicate the recommended contrnls by inserting the appropriate code(s) in column 6 from the following list.
A. Mechanical break
B. Electric break
C. Synchronous motor-generator
D. Driven unit load
E. Needle valves in jets
F. Wichet gateo
G. Inlet flow control
H. Discharge flow control
J. Guvertior
K. Adjustable blades
L. Variable displacement
M. Other

7. Estimated Turbine Efficiency

Please indicale in column 7 the estimated efflciency. 


\section{Recommended Intermediate Transmission}

Please indicate the recommended intermediate transmission by inserting the appropriate code(s) in column 8 from the following list.
A. Direct-drive, common-shaft
B. Direct-drive, coupled-shaft
E. Fluid coupling
C. Speed - increasing gear
F. Ratchet coupling
D. Speed - reducing gear
G. Clutch
H. Other (Please indicate with footnote.)

9. Catalogs

Please provide two copies of catalogs on your equipment for the following:

a. equipment for the more difficult applications;

b. the most advanced line of equipment presently manufactured by your company.

Catalog numbers and/or other identifying information may be added in column 9 .

10. Anticipated Maintenance Cost

Please consider the average annual repair and maintenance cost during the first ten years of the life of the turbine when used in the service indicated. Please insert in column 10 the number which best represents your estimate of the average annual maintenance cost as a percentage of the initial cost of the hydraulic turbine: $<5 \%,<10 \%,<25 \%,<50 \%,<100 \%$, or $>100 \%$.

11. Projected In-Service Availability

Please provide in column 11 your projection of available in-service time: $98 \%+, 95 \%+, 80 \%+, 60 \%+,<60 \%$.

12. Problem Areas

For the equipment specified for this application, please identify the most severe problems anticipated by inserting the most appropriate code(s) in column 12 from the following list.
A. Corrosion
b. Erosion
C. Pitting
D. Cavitation
E. Plugging
F. Bearings
G. Seals

\author{
H. C.1.utches \\ I. Couplings \\ J. Vibration \\ K. Governors \\ L. Intermediate transmission \\ M. Control \\ N. Valves \\ 0 . Other
}

13. Delivery Time

For equipment which you make or anticipate making, please insert in column 13 the number below which best represents the anticipated lead time in months required from order placement through installation and check out: $<6,<12,<18,<24,<36$, or $>36$. (Delivery time does not include developütenl time which should be included in item 14.)

14. Development Lead Time

For equi-pment not yet available but specified for applications listed, please state the total anticlpated time for research, development, and testing required to provide the first unit of reliable cquipment. Please state in years in column 14. 
15. Additional Comments

Other comments on specific applications are welcomed. These may be stated or footnoted in column 15. Attach additional sheets, if necessary.

16. Industry Capabilities and Quantities

Please provide your general comments and your assessment of industry's capability to supply hydraulic turbines of advanced design in sufficient quantities for demonstration and commercial coal conversion plants. This is assuming that coal conversion will become a major industry within the next cen to fifteen years. 
AVAILABILITÝ CODES FOR USE IN COMPLETING ITEM 1

\section{Available Equipment}

Available off-the-shelf equipment produced by our company.

Equipment available by special order through our company.

Equipment not presently available through our company but believed to be available within the industry.

Technology Available for Scale-up

Equipment is not presently available through our company but technology is available in-house which will likely be used if market forces are attractive.

Equipment is not presently available through our company but technology is available within the industry which will likely be used by one or more companies if market forces are attractive.

Anticipated Technology by 1982

Anticipated technology requiring $R \& D$ which will likely be funded by our company if market forces are attractive.

Anticinated technology rcquiring R\&D which can be funded by industry if market forces are attractive.

Anticipated technology requiring R\&D which can be handled through our company provided governmental assistance is available.

Anticipated technology requiring $R \& D$ which can be handled within the industry provided governmental assistance is available.

Anticipated Technology: 1982 to 1987

Very advanced future technology requiring extensive $R \& D$ which is Iikely to be handled by industry by 1987 without governmental assietance.

Very advanced future technology requiring extensive R\&D which requires governmental assistance for development by 1987 .

Questionahle Terhnnlngy

lechnology not believed possible before 1987.

Technology not believed possible for these conditions.

Inapplicable

None of the above codes are applicable or appropriate for our firm to use: Insell a luuluute in enllimin in tor additional comments, if so desired. 
Hydraul1c Turbines

To: Joel R. Horton

Union Carbide Corporation-

Nuclear Division

MS 241-A, B1dg. 1000

Post Office Box $X$

Oak Ridge, TN 37830

\section{Investigation of Industrial Coal Conversion Equipment Capability \\ Address and Reference Form for 'Manufacturers of \\ Hydraulic Turbines}

1. Please indicate below the name and address of your company as you would like to have it listed in the final report.

COMPANY

AND

DIVISION

STREET

CITY

STATE ZIP

2. Please indicate below an individual's name and address avaflable for additional communication, if necessary, during the period of this study.

NAME

COMPANY

AND

DIVISION

STREET

CITY

STATE

ZIP

3. Please indicate below the name and address of a person (or position) you would like to have the final repurt maled to.

NAME

COMPANY

AND

DIVIS ION

STREET

CITY

ZIP

Respectfully submitted.

Date

Please return this sheet together with sheet 7 of this attachment for hydraulle curbines. 


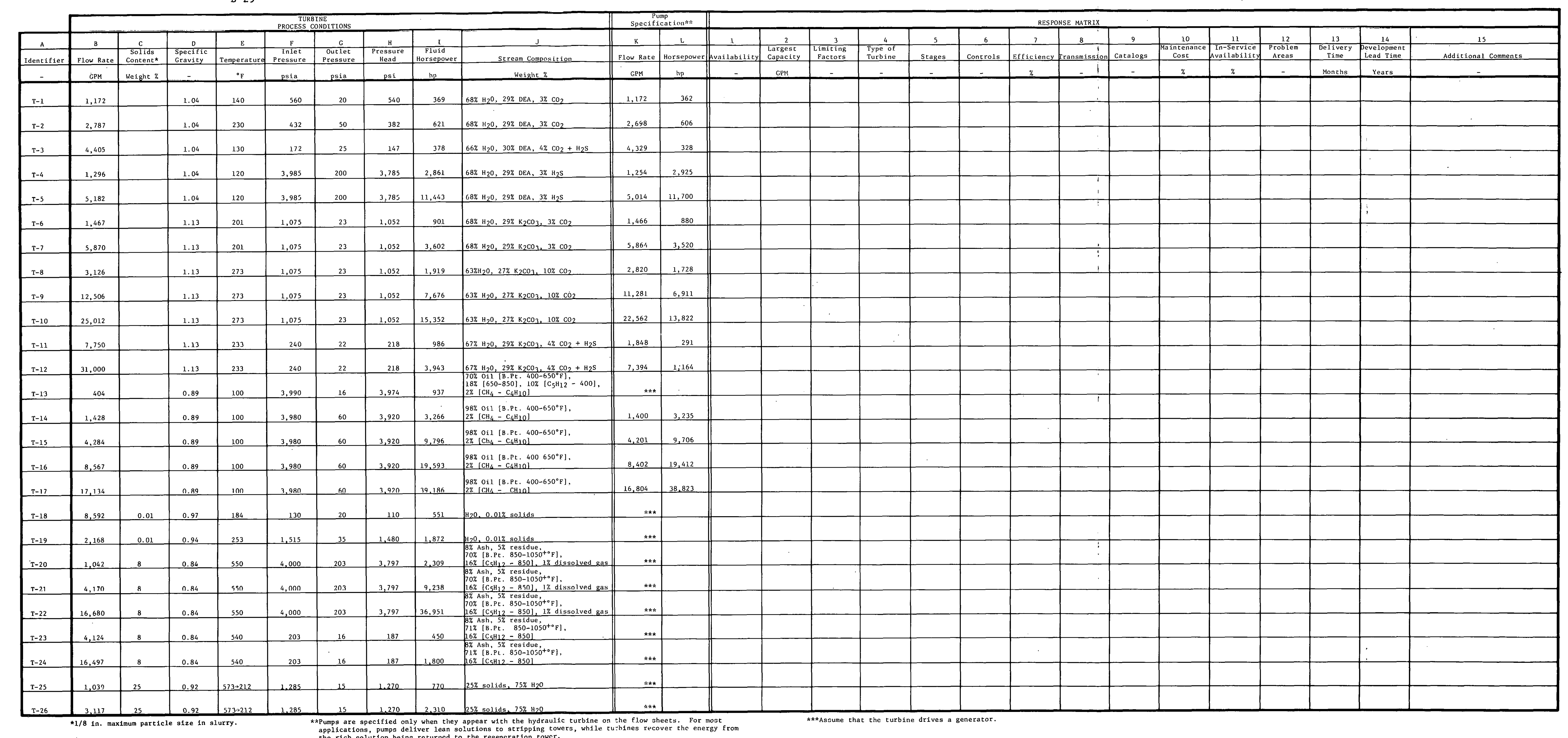




\section{ATTACHMENT}

\section{Investigation of Coal Conversion Equipment Capability}

\section{Gas Expanders}

This attachment includes spectfications for gas expanders found in recent conceptual designs of coal conversion plants and a questionnaire for determining the availability of these expanders.

Sheets 2 and 3 of this attachment list general instructions for completing the questionnaire.

Sheet 4 lists the availability code to use in completing item 1 of the instructions.

Sheet 5 is an address and reference form which should be completed to properly reference your firm and point of contact. One individual should be named on this form for further contact by telephone during this study if necessary.

Sheet 6 lists specifications for expanders in coal conversion plants and provides blank columns for inserting the information requested by this questionnaire.

We recognize that some of the questions may be too difficult or time consuming to answer. We will appreciate your effort in answering these questions to the extent possible.

NOTE: The horsepower appearing in column $I$ is expressed as ideal. It is realized that $\mathrm{few}$, if any, expanders will operate under ideal conditions. The quantity in column I is simply a measure of the maximum horsepower available to the expander under ideal conditions. 
GENERAL INSTRUCTIONS

1. Expander Avallability

Please choose the most approprlate avallability code from the 11st on sheet 4 and insert $1 \mathrm{t}$ in column 1 .

2. Largest Available Capactity

Please indicate in column 2 the largest capacity expander which you do make for the process conditions listed.

3. Limiting Factors

If your availability code in column 1 is not $A 1$ or $A 2$, please indicate the particular characteristics which are the limiring factors. Expand on this with additional sheets, if necessary, and reference footnotes in column 3.

\section{Type of Expander for Each Application}

Please indicate in column 4 the recommended type of unit for the specified service.
A. Radial - inflow
B. Radial - outward flow
C. Lobe type
E. Other

5. Stages

Please insert in column 5 the estimated number of stages.

6. Load and Speed Control

Please indicate the recommended controls by inserting the appropriate code $(s)$ in column 6 from the following list.
A. Mechanical break
B. Electric break
C. Synchronous motor-generator
E. Inlet flow control
D. Driven unit (i.e., pump, comprecsor)
F. Discharge flow control
G. Governors
H. Adjustable nozzles
1. Other

7. Estimated Expander Efficiency

Please Indicate in column 7 the estimated efficiency of the expander.

8. Recommended Intermediate Transmission

Please indicate the recommended intermediate transmission by inserting the appropriate code(s) in column 8 from the following list.
A. Direct-drive, common-shaft
B. Direct-drive, coupled-shaft
E. Fluit coupling
C. Speed - increasing gear
F. Ratchet coupling
D. Speed - reducing gear
G. Clutch
H. Other (Please Indicate with footnote.)

9. Catalogs

Please provide two copies of catalogs on your equipment for the following:

a. equipment for the more difficult applications;

b. the most advanced line of equipment presently manufactured by your company.

Catalog numbers and/or other identifying information may be added in column 9 . 


\title{
10. Ant1cipated Maintenance Cost
}

Please consider the average annual repair and maintenance cost during the first ten years of the life of the expander when used in the service indicated. Please 1nsert in column 10 the number which best represents your estimate of the average annual maintenance cost as a percentage of the initial cost of the expanders: $<5 \%,<10 \%,<25 \%,<50 \%$, $<100 \%$, or $>100 \%$.

11. Projected In-Service Availability

Please provide in column 11 your projection of avallable in-service time: $98 \%+, 95 \%+, 80 \%+, 60 \%+, 660 \%$.

\section{Problem Areas}

For the equipment specified for this application, please identify the most severe problems anticipated by inserting the most appropriate code(s) in column 12 from the following list.
A. Corrosion
B. Erosion
C. Pitting
D. Deposits
E. Plugging
F. Bearings
G. Seals

\author{
H. Clutches \\ I. Couplings \\ J. Vibration \\ K. Governors \\ L. Intermediate transmission \\ M. Control \\ N. Other
}

13. Delivery Time

For equipment which you make or anticlpate making, please insert in column 13 the number below which best represents the anticipated lead time in months required from order placement through installation and check out: $<6,<12,<18,<24,<36$, or $>36$. (Delivery time does not include development time which should be included In item 14.)

14. Development Lead Time

For equipment not yet avallable but specified for applications listed, please state the total anticipated time for research, development, and testing required to provide the first unit of reliable equipment. Pleasc state in years in column 14 .

15. Additional Comments

Other comments on specific applications are welcomed. These may he stated or footnoted in column 15. Attach additional sheets, if necessary.

16. Industry Capabilities and Quantities

Please provide your general comments and your assessment nf industry's capability to supply expanders of advanced design in sufficient quantities for demonstration and commercial coal conversion plants. This is assuming that coal conversion will become a major industry within the next ten to fifteen years. 
AVAILABILITY CODES FOR USE IN COMPLETING ITEM 1

Ava1lable Equipment

Avallable off-the-shelf equipment produced by our company.

Equipment available by spectal order through our company.

Equipment not presently available through our company but belleved to be avallable within the industry.

Technology Available for Scale-up

Equipment is not presently available through our company but technology is available in-house which will likely be used if market forces are attractive.

Equipment is not presently available through our company but technology is available within the industry which will likely be used by one or more companies if market forces are attractive.

\section{Anticipated Technology by 1982}

Anticipated technology requiring. R\&D which will likely be funded by our company if market forces are attractive.

Anticipated Lechnology requiring R\&D which can be funded by industry if market forces are attractive.

Anticipated technology requiring R\&D which can be handled through our company provided governmental assistance is available:

Anticipated technology requiring $R \& D$ which can be handled within the industry provided governmental assistance is available.

\section{Anticipated Technology: 1982 to 1987}

Very advanced future technology requiring extensive $R \& D$ which is likely to be handled by industry by 1987 without governmental assistance.

Very advanced future technology requiring extensive $R \& D$ which requires governmental assistance for development by 1987 .

3uestionable Techulugy

Technology not believed possible befure 1987.

\section{Inapplicable}

None of the above codes are applicable or appropriate for our firm to use. Insert a footnote in column 15 for additional corments, if so destred. 
To: Joel R. Horton

Union Carb1de Corporation-

Nuclear Division

MS 241-A, B1dg. 1000

Post Office Box $X$

Oak Ridge, TN 37830

\section{Investigation of Industrial Coal Conversion Equipment Capability \\ Address and Reference Form for Manufacturers \\ of \\ Expanders}

1. Please indicate below the name and address of yuur company as you would like to have it listed in the final report.

\section{COMPANY}

AND

DIVISION

STREET

CITY

STATE

ZIP

2. Please indicate below an individual's name and address available for additional communication, if necessary, during the period of this study.

NAME

COMPANY

AND

DIVISION

STREET

CITY

STATE

ZIP

3. Please indicate below the name and address of a person (or position) you would like to have the final report mailed to.

NAME

COMPANY

AND

DIVIS ION

STREET

CITY

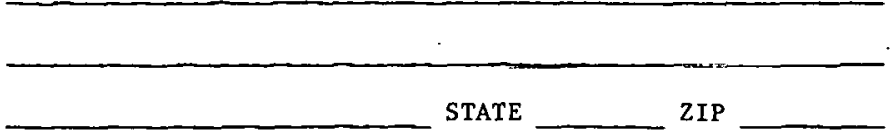

Respectfully submitted,

Date

Please return this sheet together with sheet 6 of this attachment for hydraulic turbines. 


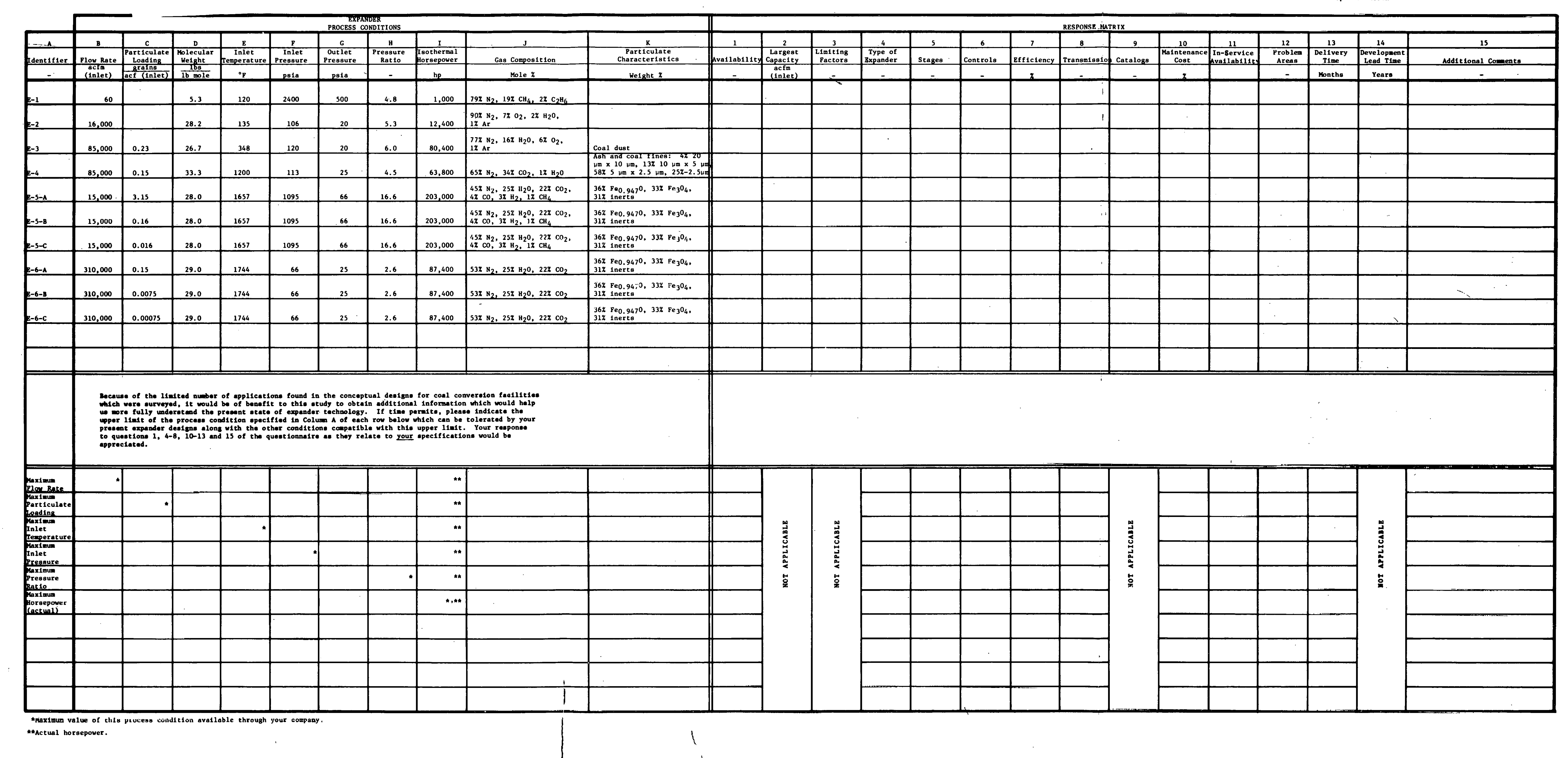


Appendix C

LOCATION OF MODELS FOR EQUIPMENT SPECIFICATIONS 


\section{PAGES C-1 to C-2 WERE INTENTIONALLY LEFT BLANK}




\section{Appendix C \\ LOCATION OF MODELS FOR EQUIPMENT SPECIFICATIONS}

This appendix is provided to facilitate the reader's further investigation of equipment applications that are characterized in the foldout pages of Appendix B. These applications are identified by alphanumeric codes consisting of one or two letters and a number separated by a hyphen. (The alphabetic portion of the code is explained in Table 3, Sect.3.3.) The identifier and the specified flow rate for each application are given in the following tables along with the process(es) that provide the model and the flow rate specified for that process. Additional information on the process which will assist in locating desired data on the model may be found in Appendix A. No spacing between identifiers (such as LL-3, LL-4, and LL-5), in Appendix A indicates that the specified operating parameters are identical except for flow rates. 
Table C.I. Location of models for pump specifications

\begin{tabular}{|c|c|c|c|}
\hline Identifier & $\begin{array}{c}\text { Specified flow rate } \\
(\mathrm{gpm})\end{array}$ & Process & $\begin{array}{l}\text { Required flow rate } \\
\text { (gpm) }\end{array}$ \\
\hline $\mathrm{LL}-1$ & 2,500 & Fischer-Tropsch & 1,200 \\
\hline$L L-2$ & 4,000 & Synthoil & 3,300 \\
\hline $\begin{array}{l}L L-3 \\
11-4 \\
L L-5\end{array}$ & $\begin{array}{r}50,000 \\
100,000 \\
200,000\end{array}$ & $\begin{array}{l}\text { Coalcon } \\
\text { Fischer-Tropsch } \\
\text { Hydrocarbonization } \\
\text { Synthoil }\end{array}$ & $\begin{array}{r}50,000 \\
50,000 \\
60,000 \\
102,200\end{array}$ \\
\hline $\begin{array}{l}\text { LL-6 } \\
\text { LL-7 }\end{array}$ & $\begin{array}{l}16,300 \\
32,600\end{array}$ & $\begin{array}{l}\text { Synthoil } \\
\text { Sny thoil }\end{array}$ & $\begin{array}{l}16,300 \\
16,300\end{array}$ \\
\hline LL-8 & 5,400 & BI-GAS & 5,400 \\
\hline$T_{1} T_{1}-9$ & $1 ., 500$ & Coalcon & 250 \\
\hline $\begin{array}{l}L L-10 \\
L L-i i\end{array}$ & $\begin{array}{l}2,600 \\
7,800\end{array}$ & $\begin{array}{l}\text { Hydrocarbonization } \\
\text { Hydrocarbonlzacton }\end{array}$ & $\begin{array}{l}2,600 \\
2,600\end{array}$ \\
\hline LL-12 & 4,000 & Synthoil & 2,000 \\
\hline $\mathrm{LL}-13$ & 800 & Synthoil & 660 \\
\hline LL-14 & 4,800 & Lurgi & 1,600 \\
\hline LL-15 & 17,000 & Coalcon & 8,500 \\
\hline LL-16 & 15,000 & Hydrocarbonization & 3,400 \\
\hline$. L L-17$ & 9,000 & Synthoil & 4,500 \\
\hline LL-18 & 8,000 & Fischer-Tropsch & 4,031 \\
\hline LL-19 & 6,400 & Synthoil & 2,150 \\
\hline LL-20 & 1,050 & $\begin{array}{l}\text { Coalcon } \\
\text { Hydrocarbonization }\end{array}$ & $\begin{array}{r}80 \\
466\end{array}$ \\
\hline $\mathrm{LL}-21$ & 7,200 & $\begin{array}{l}\text { BI-GAS } \\
\text { HYGAS }\end{array}$ & $\begin{array}{r}1,910 \\
578\end{array}$ \\
\hline LL-22 & 3,600 & Coalcon & 875 \\
\hline ML-1 & 1,500 & Coalcon & 250 \\
\hline ML-2 & 5,800 & Fischer-Tropsch & 2,900 \\
\hline $\mathrm{ML}-3$ & 440 & Fischer-Tropsch & 220 \\
\hline $\mathrm{ML}-4$ & 300 & Fischer-Tropsch & 150 \\
\hline $\mathrm{ML}-5$ & 620 & Fischer-Tropsch & 310 \\
\hline $\begin{array}{l}\mathrm{ML}-6 \\
\mathrm{ML}-7\end{array}$ & $\begin{array}{r}8,400 \\
25,200\end{array}$ & $\begin{array}{l}\text { Coalcon } \\
\text { Coalcon }\end{array}$ & $\begin{array}{l}8,400 \\
8,400\end{array}$ \\
\hline $\mathrm{ML}-8$ & 9,000 & Coalcon & 1,400 \\
\hline
\end{tabular}


Table C.1 (continued)

\begin{tabular}{|c|c|c|c|}
\hline Identifier & $\begin{array}{c}\text { Specified flow rate } \\
(\mathrm{gpm})\end{array}$ & Process & $\begin{array}{l}\text { Required flow rate } \\
(\mathrm{gpm})\end{array}$ \\
\hline ML-9 & 10,000 & Fischer-Tropsch & 4,620 \\
\hline ML-10 & 5,000 & $\begin{array}{l}\text { Fischer-Tropsch } \\
\text { Synthoil }\end{array}$ & $\begin{array}{l}1,335 \\
2,420\end{array}$ \\
\hline MM-1 & 6,000 & BI-GAS & 1,900 \\
\hline $\begin{array}{l}\mathrm{MM}-2 \\
\mathrm{MM}-3\end{array}$ & $\begin{array}{l}4,500 \\
9,000\end{array}$ & $\begin{array}{l}\text { Coalcon } \\
\text { Coalcon }\end{array}$ & $\begin{array}{l}1,500 \\
1,500\end{array}$ \\
\hline$M M-4$ & 1,300 & Hydrocarbonization & 1,300 \\
\hline $\begin{array}{l}M M-5 \\
M M-6\end{array}$ & $\begin{array}{r}8,000 \\
16,000\end{array}$ & $\begin{array}{l}\text { Coalcon } \\
\text { Coalcon }\end{array}$ & $\begin{array}{l}8,000 \\
8,000\end{array}$ \\
\hline $\mathrm{MM}-7$ & 7,200 & Lurgi & 800 \\
\hline$M M-8$ & 700 & Coalcon & 700 \\
\hline $\mathrm{HL}-1$ & 5,600 & Synthoil & 1,700 \\
\hline $\mathrm{HL}-2$ & 8,000 & HYGAS & 4,800 \\
\hline $\mathrm{HL}-3$ & 4,500 & Hydrocarbonization & 4,500 \\
\hline $\mathrm{HH}-1$ & 3,600 & BI-GAS & 1,200 \\
\hline $\mathrm{HH}-2$ & 4,400 & Synthoil & 1,100 \\
\hline $\begin{array}{l}\mathrm{HH}-3 \\
\mathrm{HH}-4\end{array}$ & $\begin{array}{l}15,600 \\
31,200\end{array}$ & $\begin{array}{l}\text { Fischer-Tropsch } \\
\text { Fischer-Tropsch }\end{array}$ & $\begin{array}{l}4,600 \\
4,600\end{array}$ \\
\hline $\begin{array}{l}\mathrm{HH}-5 \\
\mathrm{HH}-6\end{array}$ & $\begin{array}{r}3,400 \\
13,600\end{array}$ & $\begin{array}{l}\text { BI-GAS } \\
\text { Synthoil }\end{array}$ & $\begin{array}{l}3,400 \\
.3,1 \cap n\end{array}$ \\
\hline $\mathrm{HH}-7$ & 5,600 & Synthoil & 1,400 \\
\hline $\mathrm{HH}-8$ & 4,500 & Synthoil & 1,500 \\
\hline $\mathrm{HH}-9$ & 2,500 & Fischer-Trupsch & 1,250 \\
\hline $\begin{array}{l}\mathrm{HH}-10 \\
\mathrm{HH}-11\end{array}$ & $\begin{array}{r}3,600 \\
14,400\end{array}$ & $\begin{array}{l}\text { Synthoil } \\
\text { Synthoil }\end{array}$ & $\begin{array}{l}865 \\
865\end{array}$ \\
\hline $\mathrm{HH}-12$ & 4,800 & HYGAS & 400 \\
\hline $\mathrm{HH}-13$ & 5,400 & Hydrocarbonization & 1,800 \\
\hline $\mathrm{HH}-14$ & 3,600 & $\begin{array}{l}\text { BI-GAS } \\
\text { HYGAS }\end{array}$ & $\begin{array}{l}640 \\
290\end{array}$ \\
\hline
\end{tabular}


Table C.2. Location of models for compressor specifications

\begin{tabular}{|c|c|c|c|c|}
\hline Identifier & $\begin{array}{l}\text { Specified flow } \\
\text { (acfm) }\end{array}$ & rate & Process. & $\begin{array}{c}\text { Required flow rate } \\
\cdot(\mathrm{acfm})\end{array}$ \\
\hline $\mathrm{FB}-1$ & 220,000 & $\ldots \cdots$ & Synthoil. & 73,000 \\
\hline $\mathrm{FB}-2$ & 260,000 & - & $\begin{array}{l}\text { BI-GAS } \quad\left(P_{0}=15.4\right) \\
\text { Lurgi }\end{array}$ & $\begin{array}{r}44,000 \\
127,000\end{array}$ \\
\hline $\begin{array}{l}F B-3 \\
F B-4\end{array}$ & $\begin{array}{l}400,000 \\
800,000\end{array}$ & . & $\begin{array}{l}\text { BI-GAS } \\
\text { BI-GAS } \\
\text { Synthoil }\end{array}$ & $\begin{array}{l}306,000 \\
220,000 \\
115,000\end{array}$ \\
\hline $\mathrm{FB}-5$ & 600,000 & $\bullet$ & Hydrocarbonization & 575,000 \\
\hline $\begin{array}{l}\mathrm{FB}-6 \\
\mathrm{FB}-7\end{array}$ & $\begin{array}{l}\cdot 410,000 \\
1,230,000\end{array}$ &. & $\begin{array}{l}\text { Coalcon } \\
\text { Coalcon }\end{array}$ & $\begin{array}{l}410,000 \\
410,000\end{array}$ \\
\hline $\begin{array}{l}\text { FB-8 } \\
\text { FB-9 }\end{array}$ & $\begin{array}{l}360,000 \\
720,000\end{array}$ & $\cdot$ & $\begin{array}{l}\text { Hydrocarbonization } \\
\text { Hydrocarbonization }\end{array}$ & $\begin{array}{l}357,000 \\
357,000\end{array}$ \\
\hline$L-1$ & 270,000 & & Hydrncarbonization & 90,000 \\
\hline $\mathrm{L}-2$ & 220,000 & & HYGAS & 70,000 \\
\hline $\mathrm{L}-3$ & 350,000 & & Coalcon & 175,000 \\
\hline $\mathrm{L}-4$ & 910,000 & & Synthoil & 151,000 \\
\hline $\mathrm{L}-5$ & 75,000 & & Synthoil & 75,000 \\
\hline$L-6$ & 10,000 & & Coalcon & 10,000 \\
\hline $\mathrm{ML}-1$ & 82,000 & & Fischer-Tropsch & 41,000 \\
\hline $\mathrm{ML}-2$ & 11,000 & & Lurgi & 1,200 \\
\hline$M L-3$ & 20,000 & & Fischer-l'ropsch & 10,000 \\
\hline $\begin{array}{l}M L-4 \\
M L-5 \\
M L-6\end{array}$ & $\begin{array}{l}150,000 \\
30 n, 000 \\
900,000\end{array}$ & & $\begin{array}{l}\text { Synthoil } \\
\text { Synthoil } \\
\text { Synthoil }\end{array}$ & $\begin{array}{l}150,000 \\
150,000 \\
150,000\end{array}$ \\
\hline MH-1 & 400 & & Fischer-Tropsch & 180 \\
\hline $\mathrm{MH}-2$ & 35,000 & & Coalcon & 35,000 \\
\hline $\mathrm{MH}-3$ & 16,000 & & Synthoil & 8,000 \\
\hline $\mathrm{HL}-1$ & 10,000 & & HYGAS & 8,000 \\
\hline $\begin{array}{l}\mathrm{HL}-2 \\
\mathrm{HL}-3\end{array}$ & $\begin{array}{l}14,000 \\
40,000\end{array}$ & & $\begin{array}{l}\text { BI-GAS } \\
\text { BI-GAS }\end{array}$ & $\begin{array}{l}12,000 \\
12,000\end{array}$ \\
\hline $11 L-4$ & 6,000 & & Coalcon & 6,000 \\
\hline $\mathrm{HL}-5$ & 10,000 & & Lurgi & 7,100 \\
\hline$H L-6$ & 10,000 & & Fischer-Tropsch & 3,600 \\
\hline $\mathrm{HHI}-1$ & 25,000 & & Coalcon & 20,000 \\
\hline
\end{tabular}


"Table C.2 (continued)

\begin{tabular}{|c|c|c|c|c|}
\hline Identifier & $\begin{array}{l}\text { Specified flow rate } \\
\text { (acfm) }\end{array}$ & Process & $\begin{array}{l}\text { Required flow } \\
\qquad(\mathrm{accm})\end{array}$ & rate \\
\hline $\mathrm{HH}-2$ & 30,000 & Hydrocarbonization & 27,000 & \\
\hline $\mathrm{HH}-3$ & 30,000 & Synthoil & 28,000 & \\
\hline $\begin{array}{l}\mathrm{HH}-4 \\
\mathrm{HH}-5\end{array}$ & $\begin{array}{l}35,000 \\
70,000\end{array}$ & $\begin{array}{l}\text { Coalcon } \\
\text { Coalcon }\end{array}$ & $\begin{array}{l}34,000 \\
34,000\end{array}$ & \\
\hline $\mathrm{VH}-1$ & 7,000 & Synthoil & 6,300 & \\
\hline $\mathrm{VH}-2$ & 2,000 & Hydrocarbonization & 1,500 & \\
\hline $\mathrm{VH}-3$ & 80,000 & Hydrocarbontzation & 80,000 & \\
\hline $\begin{array}{l}\mathrm{VH}-4 \\
\mathrm{VH}-5\end{array}$ & $\begin{array}{r}7,000 \\
28,000\end{array}$ & $\begin{array}{l}\text { Synthoil }: \\
\text { Synthoil }\end{array}$ & $\begin{array}{l}6,600 \\
6,600\end{array}$ & . \\
\hline
\end{tabular}


Table C.3. Location of models for hydraulic turbine speciflcations

\begin{tabular}{|c|c|c|c|}
\hline Identifier. & $\begin{array}{c}\text { Specified flow rate } \\
(\mathrm{gpm})\end{array}$ & Process: & $\begin{array}{l}\text { Required " flow rate } \\
(\mathrm{gpm})\end{array}$ \\
\hline$T-1$ & 1,172 & Hydrocarbonization & \\
\hline $\mathrm{T}-2$ & 2,787 & Hydrocarbonization & . \\
\hline $\mathrm{T}-3$ & 4,405 & Hydrocarbonization & \\
\hline $\begin{array}{l}\mathrm{T}-4 \\
\mathrm{~T}-5\end{array}$ & $\begin{array}{l}1,296 \\
5,182\end{array}$ & $\begin{array}{l}\text { Synthoil } \\
\text { Synthoil }\end{array}$ & \\
\hline $\begin{array}{l}\mathrm{T}-6 \\
\mathrm{~T}-7\end{array}$ & $\begin{array}{l}1,467 \\
5,870\end{array}$ & $\begin{array}{l}\text { Synthoil } \\
\text { Synthoil }\end{array}$ & \\
\hline $\begin{array}{l}\mathrm{T}-8 \\
\mathrm{~T}-9 \\
\mathrm{~T}-10\end{array}$ & $\begin{array}{r}3,126 \\
12,506 \\
25,012\end{array}$ & $\begin{array}{l}\text { Syntholl } \\
\text { Synthoil } \\
\text { Synthoil }\end{array}$ & . \\
\hline $\begin{array}{l}T-11 \\
1-12\end{array}$ & $\begin{array}{r}7,750 \\
31,000\end{array}$ & $\begin{array}{l}\text { Synthoil } \\
\text { Synthoil }\end{array}$ & \\
\hline $\mathrm{T}-13$ & 404 & Synthoil & 101 \\
\hline $\begin{array}{l}\mathrm{T}-14 \\
\mathrm{~T}-15 \\
\mathrm{~T}-16 \\
\mathrm{~T}-17\end{array}$ & $\begin{array}{r}1,428 \\
4,284 \\
8,567 \\
17,134\end{array}$ & $\begin{array}{l}\text { Syntholl } \\
\text { Synthoil } \\
\text { Synthoil } \\
\text { Synthoil }\end{array}$ & $\begin{array}{l}1,428 \\
1,428 \\
1,428 \\
1,428\end{array}$ \\
\hline $\mathrm{T}-18$ & 8,592 & Hydrocarbonization & \\
\hline $\mathrm{T}-19$ & 2,168 & Fischer-Tropsch & \\
\hline $\begin{array}{l}\mathrm{T}-20 \\
\mathrm{i}-2 \mathrm{I} \\
\mathrm{T}-22\end{array}$ & $\begin{array}{r}1,042 \\
4,170 \\
16,680\end{array}$ & $\begin{array}{l}\text { Synthoil } \\
\text { Eynthoil } \\
\text { Synthoil }\end{array}$ & \\
\hline $\begin{array}{l}\mathrm{T}-23 \\
\mathrm{~T}-24\end{array}$ & $\begin{array}{r}4,124 \\
16,497\end{array}$ & $\begin{array}{l}\text { Synthoil } \\
\text { synthoil }\end{array}$ & \\
\hline $\begin{array}{l}\mathrm{T}-25 \\
\mathrm{~T}-26\end{array}$ & $\begin{array}{l}1,039 \\
3,117\end{array}$ & $\begin{array}{l}\text { HYGAS } \\
\text { HYGAS }\end{array}$ & \\
\hline
\end{tabular}


Table C.4. Location of models for expander specifications

\begin{tabular}{|c|c|c|c|c|}
\hline Identifier & $\begin{array}{l}\text { Specified flow. } \\
:(\text { acfm })\end{array}$ & rate & Process & $\begin{array}{c}\text { Required flow rate } \\
(\mathrm{acfm})\end{array}$ \\
\hline$E-1$ & 60 & & Hydrocarbonization & \\
\hline $\mathrm{E}-2$ & 16,000 & & Hydrocarbonization & \\
\hline$E-3$ & 85,000 & $\because$ & Hydrocarbonization & \\
\hline$E-4$ & 85,000 & . & $\mathrm{CO}_{2}$ Acceptor & 85,000 \\
\hline$E-5^{a}$ & 15,000 & & HYGAS (Steam-Iron) & 15,000 \\
\hline$E-6^{a}$ & 310,000 & & HYGAS (Steam-Iron) & 310,000 \\
\hline
\end{tabular}

$a_{A}$ represents no cleanup of gas; $B$ represents $95 \%$ cleanup of gas; C represents $99.9 \%$ cleanup of gas. 
Appendix D

MANUFACTURERS RESPONDING TO ROTATING EQUIPMENT QUESTIONNAIRES 


\section{PAGES D-1 to D-2 WERE INTENTIONALLY LEFT BLANK}


Appendix D

MANUFACTURERS RESPONDING TO ROTATING EQUIPMENT QUESTIONNAIRES

The manufacturers listed in this section have provided information on rotating equipment for coal conversion facilities in response to the questionnaires (see Appendix B). The names and addresses appearing below have been supplied.by the manufactuers themselves. Their responses to the first two questions of the questionnaire on availability and largest capacities are given in Appendix Еे.

\section{Pump Manufacturers}

Barrett, Haentjens \& Co. Box 488

Hazleton, $\mathrm{Pa} .18201$

Bingham-Williamette Co. 2800 Northwest Front Avenue Portland, Oreg. 97210

Buffalo Forge Co. Pump Division

P.0. Box 985

Buffalo, N.Y. 14240

Byron Jackson Pump Division Borg-Warner Corp. P.0. Box 2017 Terminal Annex T.ns Anqeles, Calif. 90051

Colt Industries Operating Corp. Fairbanks Morse Pump Division 3601 Kansas Avenue

Kansas City, Kans. 66110

Delaval Turbine, Inc. IMO Pump Division

P.O. Box 321

Trenton, N.J. 08602
Delaval Turbine, Inc. Turbine Division

P.O. Box 251

Trenton, N.J. 08602

Dover Corp.

Blackmer Pump Division

1809 Century

Grand Rapids, Mich. 49506

Dresser Industries, Inc.

Pacific Pump Division

5715 Bickett Street

Huntington Park, Calif. 90255

The Duriron Co., Inc.

Central Division

425 North Findlay Street

Dayton, Ohio 45401

Galigher Co.

Baker International

440 West 8 th South

Salt Lake City, Utah 84110

Ingersol1 wand Co. Cameron Pump Division

P.0. Box 486

Phillipsburg, N.J. 08865 
Ingersoll-Rand Co.

Standard Puinp - Aldrich Division

Allentown, Pa. 18105

LaBour Pump Co.

P.0. Box 1187

Elkhart, Ind. 46514

Lawrence Pumps, Inc.

371 Market Street

Lawrence, Mass. 01843 .

Morris Pumps, Inc.

31 East Genesee Street

Baldwinsville, N.Y. 13027.

National Supply Co.

Division of Armco Steel Corp.

1455 West Loop South

Houston, Tex. 77027

Peabody Floway, Inc.

P.0. Box 164

Fresno, Calif. 93707

Roper Pump Co.

Box 269

Commerçe, Ga. 30529
Tuthill Pump Co.

Chicago Division

12500 South Crawford Avenue

Chicago, I11. 606598

United Centrifugal Pumps

1132 North Seventh Street

San Jose, Calif. 95112

Warren Pumps, Inc.

Subsidiary of Houdaille Industries,

Inc.

Warren, Mass. 01083

A. R. Wilfley \& Sons, Inc.

P.0. Box 2330

Denver, Colo. 80201

Wilson-Snyder Pumps

United States Steel Corp.

2001 N. Lamar Street, Box 478

Dallas, Tex. 75221

Worthington (Canada) Ltd.

P.0. Box 40

Brantford, Ontario N3T 5M5

Canada

Zimpro, Inc.

Subsidiary of Sterling Drug

Military Road

Rothschild, Wis. 54474

\section{Compressor Manufacturers}

Airco Cryogenics

1900 Main Street

Irvine, Calif. 92716

Allis-Chalmers Corp. Compressor Division

P.0. Box 512

Milwaukee, Wis. 53201

American Demag Corp.

Compression Equipment Division

450 Park Avenue

New York, N.Y. 10022
Beloit Power Systems, Inc.

Tang Industries

555 Lawton Avenue

Beluit, Wis. 53511

Delaval Turb1ne, Inc.

Centrifugal Compressor Division

P.O. Box 251

Trenton, N.J. 08602

Diebold, Inc.

Lamson Division

685 Lamson Street

Syracuse, N.Y. 13201 
Dresser Industries, Inc. Dresser Clark Division P.O. Box 560

Olean, N.Y. $14760^{\circ}$

Elllot Company Division of Carrier Corp. North Fourth Street

Jeannette, $\mathrm{Pa} .15644$

Gardner-Denver Co. Industrial Machinery Division 1800 Gardner Expressway Quincy, I11. 62301

Ingerso11-Rand Co. Turbo Products Division 942 Memorial Parkway

Ph1llipsburg, N.J. 08865

Joy Manufacturing Co. 3101 Broadway

Buffalo, N:Y. 14225

Mechanical Equipment'Co., Inc. 861 Carondelet Street

New Orleans, La. 70130
Rotoflow Corp. 2235 Carmelina Avenue Los Angeles, Calif. 90064

The Spencer Turbine Co. Turbo Compressor Division 600 Day H 111 Road Windsor, Conn. 06095

Sulzer Brothers, Inc. 19 Rector Street New York; N.Y. 10006

Turbonetics, inc. 968 Albany-Shaker Road Latham, N.Y.' '12110

Westinghouse Electric Corp. Marine Marketing Division Hendy Avenue Sunnyvale, Calif. 94088

York Division Borg-Warner Corp. P.0. Box 1592 York; Pa. 17405

\section{Hydraulic Turbine Manufacturers}

Abex Corp.

Denison Division

1160 Dublin Koad

Columbus, Oh1o 43216

Allis-Chalmers Corp. Hydro-Turbine Division

Box 712

York, Pa., 17405
Byron Jackson Pump Division Borg-Warner Corp. P.0. Box 2017. Terminal Annex Los Angeles, Calif. 90051

Dresser Industries, Inc. Pacific Pumps Division 5715 Bickett Street Huntington Park, Ca1if. 90255

Bingham-Williamette Co. 2800 Northwest Front Avenue Portland, Oreg. 97210 
Expander Manufacturers

Airco Cryogenics 1900 Main Street Irvine, Calif. 92716

Beloit Power Systems, Inc. Tang Industries 555 Lawton Avenue Beloit, Wis. 53511

Delaval Turbine, Inc. Turbine Division P.O. Box 251

Trenton, N.J. 08602

Dresser Industries, Inc. Dresser Clark Division P.0. Box 560

OTean, N.Y. 14760
Elliot Company

Division of Carrier Corp. North Fourth Street

Jeannette, $\mathrm{Pa}$. 15644

Ingersoll-Rand Co. lurbo Products Division 942 Memorial Parkway

Phillipsburg, N.J. 08865

Rotoflow Corp.

Engineering $I$

2235 Carmelina Avenue

Los Angeles, Calif. 90064

Westinghouse Electric Corp. Marine Marketing Division Hendy Avenue

Sunnyvale, Calif. 94088 
Appendix E

RESPONSES FROM MANUFACTURERS TO QUESTIONS ON AVAILABILITY AND CAPACITY 


\section{PAGES E-1 to E-2 WERE INTENTIONALLY LEFT BLANK}




\section{Appendix E \\ RESPONSES FROM MANUFACTURERS TO QUESTIONS ON \\ AVAILABILITY AND CAPACITY}

This appendix is a tabulation of responses from manufacturers to questions on availability and capacity (see Appendix B, questions 1 and 2 of each questionnaire). These data are presented exactly as they were provided by the manufacturers. Section 4 of this report provides a summary of the responses on availability and capacity as well as a summary of the responses to the remaining questions asked in the questionnaires and of additional information obtained from the manufacturers. Section 5 should be consulted for an analysis of the data.

The following tables are arranged first in the order of type of equipment (pump, compressors, hydraulic turbines, and gas expanders) and second by series (pumps: LL, ML and MM, and HL and HH series; compressors: $\mathrm{FB}, \mathrm{L}, \mathrm{ML}$, and $\mathrm{MH}$; and $\mathrm{HL}, \mathrm{HH}$, and $\mathrm{VH}$ series). Information within these latter subdivisions is then arranged alphabetically by manufacturers. 
Table E.1. Responses Erom manufacturers to questions on availability and capacity

Pumps: LL series

\begin{tabular}{|c|c|c|c|c|c|c|c|c|c|}
\hline \multirow[b]{3}{*}{ Identifier } & \multicolumn{9}{|c|}{ Manufactırer } \\
\hline & \multicolumn{2}{|c|}{ Barrett, Haentjens $\&$ Co. } & \multicolumn{2}{|c|}{ Bingham-Willamette Co. } & \multicolumn{3}{|c|}{ Buffalo Forge Co. } & \multicolumn{2}{|c|}{ Byron Jackson } \\
\hline & Availability & $\begin{array}{l}\text { Largest } \\
\text { capacity } \\
\text { (gpm) }\end{array}$ & Availability & $\begin{array}{l}\text { Largest } \\
\text { capacity } \\
\text { (gpm) }\end{array}$ & Availabili & it $;$ & $\begin{array}{l}\text { Large.st } \\
\text { capacity } \\
(\mathrm{gpm})\end{array}$ & Availability & $\begin{array}{c}\text { Largest } \\
\text { capacity } \\
\text { (gpm) }\end{array}$ \\
\hline LL-1 & $\mathrm{A} 2$ & & A2 & 10,000 & $\mathrm{~A} 2$ & & 4,5010 & A2 & 3,700 \\
\hline $\mathrm{LL}-2$ & A2 & & A2 & 12,000 & $\mathrm{~A} 2$ & & 9,060 & A2 & 5,000 \\
\hline$L L-3$ & $\mathrm{~A} 2$ & 25,000 & $\mathrm{~A} 2$ & 200,000 & A3 & & & A2 & 73,000 \\
\hline $\mathrm{LL}-4$ & & & $A 2$ & 200,000 & A3 & & & A2 & 130,000 \\
\hline$L L-5$ & & & A2 & 200,000 & A3 & & & A2 & 238,000 . \\
\hline $\mathrm{LL}-6$ & A2 & & $A 2$ & 25,000 & A3 & & & A2 & 24,000 \\
\hline $\mathrm{LL}-7$ & A2 & & A2 & 35,000 & A3 & & & A2 & 37,000 \\
\hline $\mathrm{LL}-8$ & $\mathrm{~A} 2$ & & $A 2$ & 25,000 & A2 & & 6,600 & A2 & 64,000 \\
\hline LL-9 & A2 & & A2 & 25,000 & $\mathrm{~A} 2$ & + & 2,200 & A1. & 27,000 \\
\hline LL-10 & A2 & & $\mathrm{A} 2$ & 25,000 & A2 & & 4,000 . & $\mathrm{A} 2$ & 2,800 \\
\hline $\mathrm{LL}-11$ & A2 & & A2 & 25,000 & $\mathrm{~A} 2$ & & 8,400 & A2 & 8,300 \\
\hline $\mathrm{LI}-12$ & $A 2$ & & $\mathrm{~A} 2$ & 25,000 & $A 2$ & & 5,000 & A2 & 5,200 \\
\hline LL-13 & $\mathrm{A} 2$ & & $\mathrm{~A} 2$ & $\begin{array}{r}15,000 \\
8,000\end{array}$ & A2 & & 1,400 & $\mathrm{Al}$ & 1,400 \\
\hline LL-14 & $\mathrm{A} 2$ & & $\mathrm{~A} 2$ & 10,000 & $A 3$ & & & $\mathrm{~A} 2$ & 5,500 \\
\hline LL-15 & A2 & & $\mathrm{A} 2$ & 40,000 & A3 & & & & \\
\hline LL-16 & A2 & & $\mathrm{A} 2$ & 15,000 & A3 & & & & \\
\hline LL-I 7 & $\mathrm{~A} 2$ & & A2 & 15,000 & $\mathrm{~A} 2$ & 1 & 12,000 & & \\
\hline LL-18 & A2 & & A2 & 15,000 & $\mathrm{~A} 2$ & & 8,500 & & \\
\hline LL-19 & A2 & & A2 & 15,000 & A3 & & & & \\
\hline$L L-20$ & A2 & & A2 & 20,000 & A2 & & 1,250 & & \\
\hline$L L-21$ & A2 & & A2 & 10,000 & A3 & & & & \\
\hline $\mathrm{LL}-22$ & A2 & & A2 & 10,000 & A3 & . & & & \\
\hline
\end{tabular}


Table E.7. Responses from manufacturers to questions on availability and capacity Gas expanders

\begin{tabular}{|c|c|c|c|c|c|c|c|c|}
\hline \multirow[b]{3}{*}{ Identifier } & \multicolumn{8}{|c|}{ Manufacturer } \\
\hline & \multicolumn{2}{|c|}{ Airco Cryogenics } & \multicolumn{2}{|c|}{ Beloit } & \multicolumn{2}{|c|}{ Delaval } & \multicolumn{2}{|c|}{ Dresser Industries } \\
\hline & Availability & $\begin{array}{l}\text { Largest. } \\
\text { capacity } \\
(\operatorname{acfm})\end{array}$ & Availability & $\begin{array}{l}\text { Largest } \\
\text { capacity } \\
(\text { acfm) }\end{array}$ & Availability & $\begin{array}{l}\text { Largest } \\
\text { capacity } \\
(\operatorname{acfm})\end{array}$ & Availability & $\begin{array}{l}\text { Largest } \\
\text { capacity } \\
\text { (acfm) }\end{array}$ \\
\hline $\mathrm{E}-1$ & $\mathrm{~A} 2$ & & $\mathrm{~F}$ & & A3 & 90,000 & A3 & \\
\hline $\mathrm{E}-2$ & A2 & & $\mathrm{A} 2$ & 16,000 & $\mathrm{~B} 1$ & 90,000 & A3 & \\
\hline$E-3$ & A2 & & $\mathrm{Bl}$ & 16,000 & $\mathrm{BI}$ & 90,000 & A2 & 70,000 \\
\hline E-4. & $\mathrm{A} 2$ & & $\mathrm{~F}$ & & $\mathrm{BI}$ & 90,000 & $\mathrm{~A} 2$ & 85,000 \\
\hline E-5-A & $\mathrm{BI}$ & & $\mathrm{F}$ & & & & B2 & . \\
\hline E- $5-B$ & $\mathrm{Bl}$ & & $\mathrm{F}$ & & & & $\mathrm{B} 2$ & \\
\hline E-5-C & $\mathrm{B} 1$ & . & $\mathbf{F}$ & & & & $\mathrm{B} 2$ & \\
\hline E-6-A & $\mathrm{c} 3$ & & $F$ & . & & & A3 & \\
\hline$E-6-B$ & c3 & & $\mathrm{F}$ & & & & A3 & \\
\hline \multirow[t]{4}{*}{$E-6-C$} & C3 & & $\mathrm{F}$ & & & & A3 & \\
\hline & \multirow{2}{*}{\multicolumn{6}{|c|}{ Manufacturer }} & . & \\
\hline & & & & & & & & \\
\hline & \multicolumn{2}{|c|}{ Elliott 2o. } & \multicolumn{2}{|c|}{$\begin{array}{l}\text { Ingersoll Rand Co. } \\
\text { Turbo Products Division }\end{array}$} & \multicolumn{2}{|c|}{ Rotoflow Corf. } & \multicolumn{2}{|c|}{$\begin{array}{l}\text { Westinghouse Electric } \\
\text { Corp. }\end{array}$} \\
\hline Ićentifier & Availability & $\begin{array}{l}\text { Largest } \\
\text { capacity } \\
\text { (acfm) }\end{array}$ & Avallability & $\begin{array}{c}\text { Largest } \\
\text { capacity } \\
(\text { acfm) }\end{array}$ & Availability & $\begin{array}{l}\text { Largest } \\
\text { capacity } \\
\text { (acfm) }\end{array}$ & Availability & $\begin{array}{l}\text { Largest } \\
\text { capacity } \\
(\text { acfm) }\end{array}$ \\
\hline$E-1$ & $\mathrm{~A} 2$ & & B2 & & $\mathrm{A} 2$ & 78 & & \\
\hline $\mathrm{E}-2$ & A2 & & $\mathrm{B} 2$ & 30,000 & $\mathrm{~A} 2$ & 20,800 & & \\
\hline$E-3$ & $\mathrm{~B} 1$ & & B2 & 125,000 & $\mathrm{~A} 2$ & 110,500 & & \\
\hline$E-4$ & $\mathrm{BI}$ & & $\mathrm{Cl}$ & 125,000 & E2 & & & \\
\hline$E-5-A$ & D2 & & $\mathrm{D} 2$ & 35,000 & $\mathrm{E} 2$ & & $\mathrm{Bl}$ & 15,000 \\
\hline$E-5-B$ & $\mathrm{D} 2$ & & D2 & 35,000 & $\mathrm{E} 2$ & & $\mathrm{BI}$ & 15,000 \\
\hline$E-5-=$ & D2 & $\cdot$ & $\mathrm{D} 2$ & 35,000 & $\mathrm{E} 2$ & & B1 & 15,000 \\
\hline$E-6-A$ & c3 & & $\mathrm{C} 3$ & 310,000 & E2 & & $\mathrm{B} 1$ & 310,000 \\
\hline$E-6-B$ & $\mathrm{~A} 2$ & & C3 & 310,000 & E2 & . & $\mathrm{BI}$ & 310,000 \\
\hline$E-6-C$ & A2 & . & c3 & 310,000 & $E 2$ & & $\mathrm{BI}$ & $310 ; 000$ \\
\hline
\end{tabular}


Table E.1 (continued)

\begin{tabular}{|c|c|c|c|c|c|c|c|c|}
\hline \multirow[b]{3}{*}{ Identifier } & \multicolumn{8}{|c|}{ Manufacturer } \\
\hline & \multicolumn{2}{|c|}{$\begin{array}{l}\text { Coltindustries } \\
\text { Fairbanks Morse }\end{array}$} & \multicolumn{2}{|c|}{$\begin{array}{l}\text { Delaval IMO } \\
\text { Division }\end{array}$} & \multicolumn{2}{|c|}{$\begin{array}{c}\text { Delaval Turbine } \\
\text { Division }\end{array}$} & \multicolumn{2}{|c|}{ Dover Corp. } \\
\hline & Availability & $\begin{array}{l}\text { Largest } \\
\text { capacity } \\
\text { (gpm) }\end{array}$ & Availability & $\begin{array}{l}\text { Largest } \\
\text { capacity } \\
\text { (gpm) }\end{array}$ & Availability & $\begin{array}{l}\text { Largest } \\
\text { capacity } \\
(\mathrm{gpm})\end{array}$ & Availability & $\begin{array}{c}\text { Largest } \\
\text { capacity } \\
(\mathrm{gpm})\end{array}$ \\
\hline LL-1 & & & Al & 9,600 & $\mathrm{~A} 2$ & 50,000 & & \\
\hline LL-2 & & & Al & 9,600 & A2 & 50,000 & & \\
\hline$L L-3$ & A2 & 50,000 & & & $\mathrm{~A} 2$ & 210,000 & & $\cdot$ \\
\hline $\mathrm{LL}-4$ & A2 & 100,000 & & & $A 2$ & 210,000 & & \\
\hline$L L-5$ & & & & & $\mathrm{~A} 2$ & 210,000 & & \\
\hline LL-6 & & & A2 & 9,600 & A2 & 35,000 & & \\
\hline $\mathrm{LL}-7$ & & & A2 & 9,600 & $\mathrm{~A} 2$ & 35,000 & & \\
\hline LL-8 & $\mathrm{A} 2$ & 5,400 & $\mathrm{~A} 2$ & 9,600 & A3 & & & \\
\hline LL-9 & $\mathrm{A} 2$ & 1,500 & $\mathrm{~A} 1$ & 9,600 & & & A1 & 750 \\
\hline LL-10 & & & Al & 9,600 & & & Al & 1,175 \\
\hline$L L-11$ & & & $\mathrm{Al}$ & 9,600 & & & & \\
\hline$L L-12$ & A.2 & 4,800 & $A 1$ & 9,600 & & & & \\
\hline LL-13 & & & $\$ 2$ & 5,000 & & & , & \\
\hline LL-14 & & & B1 & 5,000 & & & . & \\
\hline LL-15 & A.2 & $17,0: 00$ & A3 & & & & & \\
\hline LL-16 & & & A3 & & & & & \\
\hline LL-17 & & & A3 & & & & & \\
\hline LL-18 & & & A3 & & & & & \\
\hline LL -19 & & & A3 & & & & & \\
\hline LL-20 & . & & A3 & & & & & \\
\hline LL-2I & & & $\mathrm{C} 2$ & & & & & \\
\hline LL-22. & & & $\mathrm{C} 2$ & & & & & \\
\hline
\end{tabular}


Table E.1 (continued)

\begin{tabular}{|c|c|c|c|c|c|c|c|c|}
\hline \multirow[b]{3}{*}{ Identifier } & \multicolumn{8}{|c|}{ Manufa=turer } \\
\hline & \multicolumn{2}{|c|}{$\begin{array}{l}\text { Dresser Industries } \\
\text {. Pacific Pump }\end{array}$} & \multicolumn{2}{|c|}{ The Juriron Co., Inc. } & \multicolumn{2}{|c|}{ Galigher Co. } & \multicolumn{2}{|c|}{$\begin{array}{l}\text { Ingersoll-Rand Co. } \\
\text { Cameron Pump Division }\end{array}$} \\
\hline & Availability & $\begin{array}{l}\text { Largest } \\
\text { capacity } \\
(\mathrm{gpm})\end{array}$ & Availability & $\begin{array}{l}\text { Largest } \\
\text { capacity } \\
(\mathrm{gpm})\end{array}$ & Availabilicy & $\begin{array}{l}\text { Largest } \\
\text { capacity } \\
\text { (gpn) }\end{array}$ & Availability & $\begin{array}{c}\text { Largest } \\
\text { capacity } \\
(\text { gpm) }\end{array}$ \\
\hline$L L-1$ & A2 & 40,000 & $A i$ & 6,000 & A1 & 4,000 & $\mathrm{Al}, \mathrm{A} 2$ & as req' $\mathrm{d}$ \\
\hline$L I-2$ & $\mathrm{~A} 2$ & 40,000 & $A=$ & & A3 & & $A 1, A 2$ & as req'd \\
\hline LL-3 & A2 & 55,000 & $A=$ & & A3 & . & $\mathrm{A} 2$ & as req'd \\
\hline LL-4 & $\dot{\mathrm{B}} 1$ & & $A \equiv$ & & $\mathrm{A} 3$ & & A2 & as $\mathrm{req}^{\top} \mathrm{d}$ \\
\hline$L L-5$ & $\mathrm{BI}$ & & $A \equiv$ & & A3 & & $\mathrm{A} 2$ & as req'd \\
\hline$L L-6$ & $\mathrm{~A} 2$ & 18,000 & $\dot{A} \Xi$ & & A3. & $\sim$ & $\mathrm{A} 2, \mathrm{~B} 1, \mathrm{~B} 2$ & \\
\hline $\mathrm{LL}-7$ & B1 & & $A \Xi$ & & A3. & & $\mathrm{A} 2, \mathrm{~B} 1, \mathrm{~B} 2$ & \\
\hline LL-8 & $\mathrm{A} 2$ & 40,000 & Al & 6.000 & A1 & $10, C 00$ & A2 & 8,000 \\
\hline LL-9 & $\mathrm{A} 2$ & 40,000 & Al & 6,000 & Al & 2,400 & A2 & 8,000 \\
\hline LL-10 & A2 & 16,000 & $\mathrm{Al}$ & 6,000 & A3 & & $\mathrm{A} 2$ & 8,000 \\
\hline LL-11 & $\mathrm{A} 2$ & 16,000 & $\mathrm{Bl}$ & & A3 & & A2 & 8,000 \\
\hline LL-12 & A2 & 40,000 & Al & 6,000 & A1 & 4,000 & A2 & 8,000 \\
\hline LL-13 & A2 & 16,000 & $A 2$ & 6,000 & A3 & & A2 & 8,000 \\
\hline LL-14 & $\mathrm{A} 2$ & 16,000 & A3 & & A3 & & A2 & 8,000 \\
\hline LL-15 & $\mathrm{A} 2$ & 40,000 & A 3 & & A3 & & A2 & \\
\hline LL-16 & B1 & 18,000 & $\mathrm{E} 2$ & & A3 & . & B1, B2 & . \\
\hline$L L-17$ & $\mathrm{~A} 2$ & 16,000 & $\mathrm{~B} 2$ & & A3 & & $\mathrm{B} 1, \mathrm{~B} 2$ & \\
\hline LL-18 & $\mathrm{A} 2$ & 16,000 & $\mathrm{Bl}$ & & $\mathrm{Al}$ & 10,020 & A2 & \\
\hline LL-19 & $\mathrm{A} 2$ & 16,000 & $\mathrm{Bl}$ & & $\mathrm{A}^{3}$ & & $\mathrm{~B} 1, \mathrm{~B} 2$ & $\cdot$ \\
\hline LL-20 & B1 & & $A I$ & 1,500 & $\mathrm{Al}$ & 2,430 & A2 & \\
\hline LL-21 & $\mathrm{B} 1$ & & 31 & & $\mathrm{Al}$ & 10,000 & $\mathrm{BI}$ & \\
\hline $\mathrm{LL}-22$ & $\mathrm{~B} 1$ & & $\mathrm{Bl}$ & & $A 1$ & 4,000 & A2 & \\
\hline
\end{tabular}


Table E.1 (continued)

\begin{tabular}{|c|c|c|c|c|c|c|c|c|}
\hline \multirow[b]{3}{*}{ Identifier } & \multicolumn{8}{|c|}{ Manufacturer } \\
\hline & \multicolumn{2}{|c|}{$\begin{array}{l}\text { Ingersoll Rand Co. } \\
\text { SPAD }\end{array}$} & \multicolumn{2}{|c|}{ LaBour Pump Co. } & \multicolumn{2}{|c|}{ Lawrence Pumps, Inc. } & \multicolumn{2}{|c|}{ Morris Pumps, Inc. } \\
\hline & Availability & $\begin{array}{l}\text { Largest } \\
\text { capacity } \\
\text { (gpm) }\end{array}$ & Availability & $\begin{array}{c}\text { Largest } \\
\text { capacity } \\
(\mathrm{gpm})\end{array}$ & Availability & $\begin{array}{l}\text { Largest } \\
\text { capacity } \\
\text { (gpm) }\end{array}$ & Availability & $\begin{array}{l}\text { Largest } \\
\text { capacity } \\
\text { (gpm) }\end{array}$ \\
\hline LL-1 & & & Al & 3,000 & A3 & & A3 & \\
\hline LL-2 & & & $\mathrm{A} 3, \mathrm{~B} 1$ & & A3 . & & A3 & \\
\hline LL-3 & . & & A3 & & A3 & & A3 & \\
\hline $\mathrm{LL}-4$ & & & A3 & & A3 & . & A3 & \\
\hline LL-5 & & & A3 & & A3 & . & A3 & \\
\hline $\mathrm{LL}-6$ & & & A3 & & A3 & - & A3 & \\
\hline LL -7 & & & A3 & & A3 & .. & A3 & \\
\hline LL-8 & . & & $\mathrm{A} 3, \mathrm{B1}$ & & A3 & & A3 & \\
\hline LL-.9 & & & $\mathrm{Al}$ & 3,000 & A3 & & A3 & \\
\hline LL-10 & & & $\mathrm{Al}$ & 3,000 & A3 & & A3 & \\
\hline LL-11 & & & $\mathrm{A} 3, \mathrm{~B} 1$ & & A3 & & A3 & \\
\hline LL-12 & & & $\mathrm{A} 3, \mathrm{~B} 1$ & & A3 & & A3 & . \\
\hline LL-13 & & & $\mathrm{Al}$ & 3,000 & A3 & & A3 & \\
\hline LL-14 & & · & $\mathrm{A} 3, \mathrm{~B} 1$ & & A2 & 5,000 & A3 & \\
\hline LL-15 & & & $A 3$ & & A2 & 20,000 & A2 & 70,000 \\
\hline LL -16 & & & A3 & & A2 & 20,000 & Bl & 70,000 \\
\hline LL-17 & & . & A3 & & A2 & 20,000 & BI & 20,000 \\
\hline LL-18 & & . & A3 & & $\mathrm{A} 2$ & 20,000 & A2 & 20,000 \\
\hline LL-19 & & & A3 & & A2 & 20,000 & B1 & 20,000 \\
\hline LL-20 & & & A3 & & A2 & 20,000 & $\mathrm{~A} 2$ & 20,000 \\
\hline LL-2I & & & A3 & & A2 & 20,000 & A2 & 20,000 \\
\hline LL-22 & & & A3 & & A2 & 20,000 & A2 & 20,000 \\
\hline
\end{tabular}


Table E.1 (continued)

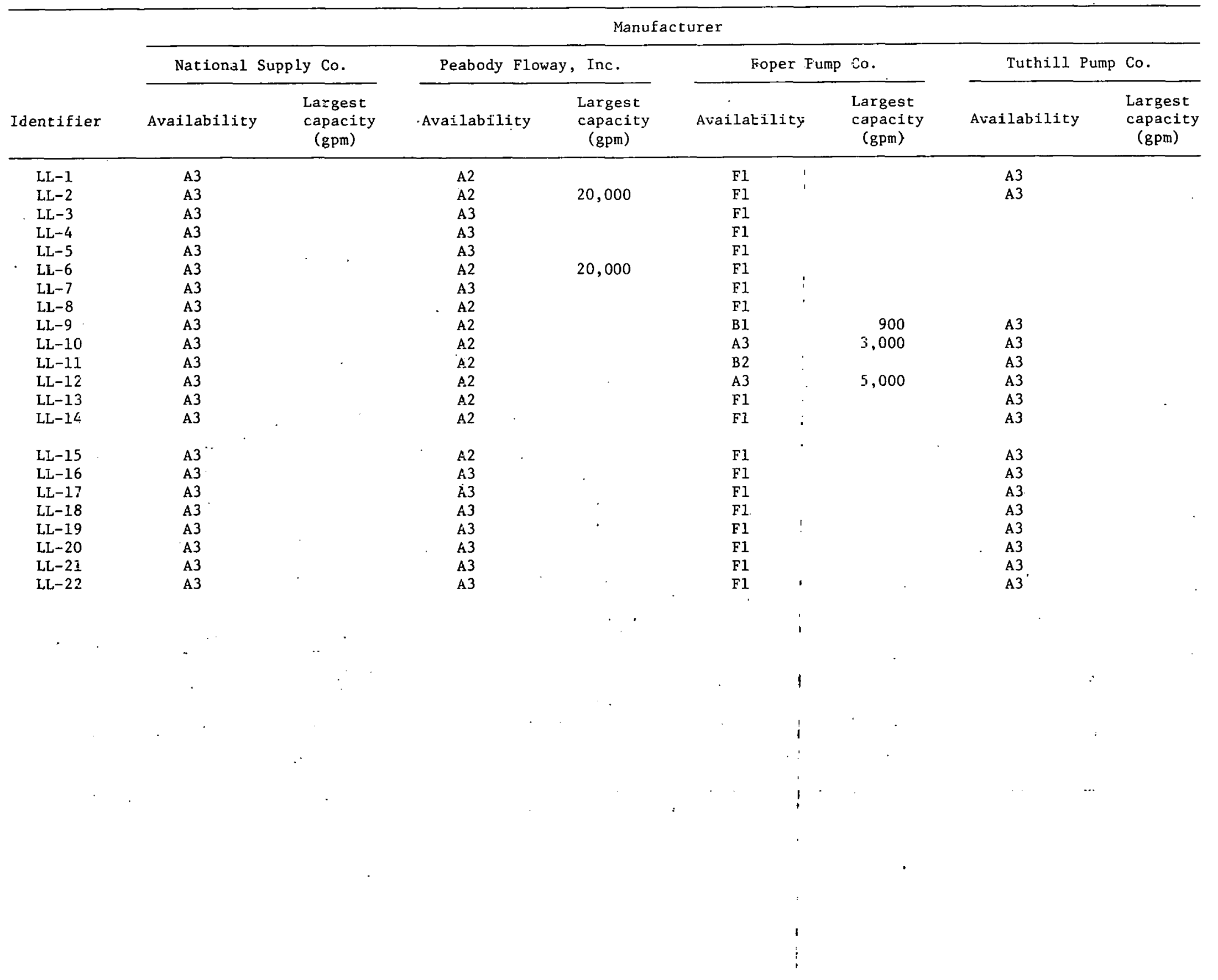


Table E.1 (continued)

\begin{tabular}{|c|c|c|c|c|c|c|c|c|}
\hline \multirow[b]{3}{*}{ Identifier } & \multicolumn{8}{|c|}{ Manufacturer } \\
\hline & \multicolumn{2}{|c|}{ United } & \multicolumn{2}{|c|}{ Warren Pumps, Inc. } & \multicolumn{2}{|c|}{ Wilfley } & \multicolumn{2}{|c|}{ Wilson-Snyder Pumps } \\
\hline & Availability & $\begin{array}{l}\text { Largest } \\
\text { capacity } \\
\text { (gPm) }\end{array}$ & Availability & $\begin{array}{l}\text { Largest } \\
\text { capacity } \\
(\mathrm{gpm})\end{array}$ & Availability & $\begin{array}{l}\text { Largest } \\
\text { capacity } \\
\text { (gpn) }\end{array}$ & Availability & $\begin{array}{c}\text { Largest } \\
\text { capacity } \\
\text { (gpm) }\end{array}$ \\
\hline$L L-I$ & $\mathrm{Al}$ & 3,000 & A2 & 100,000 & A3 & & A2 & 25,000 \\
\hline $\mathrm{LL}-2$ & $\mathrm{~A} 1$ & 4,800 & $\mathrm{~A} 2$ & 100,000 & A3 & & A2 & 25,000 \\
\hline$L L-3$ & B1 & & $\mathrm{A} 2$ & 100,000 & A3 & & A3 & 25,000 \\
\hline LL-4 & A3 & & A2 & 100,000 & A3 & & A3 & 25,000 \\
\hline$L L-5$ & A3 & & & & A3 & & A3 & 25,000 \\
\hline LL-6 & Al & 19,601 & A2 & 100,000 & $\mathrm{Bl}$ & & A3 & 25,000 \\
\hline$L L-7$ & Al & 39,000 & $\mathrm{~A} 2$ & 100,000 & B1 & - & A3 & 25,000 \\
\hline LL-8 & A1 & 6,5010 & A2 & 100,000 & $\mathrm{Al}$ & 12,000 & A3 & 25,000 \\
\hline LL-9 & $\mathrm{Al}$ & 1,801 & A2 & 4,000 & A3 & & $\mathrm{A} 2$ & 25,000 \\
\hline LL-10 & A1 & 3,103 & A2 & 4,000 & A3 & & A3 & 25,000 \\
\hline . $\quad L L-11$ & $\mathrm{~A} 2$ & 9,350 & & & A3 & & A3 & 25,000 \\
\hline LL-12 & A1 & 4,800 & A2 & 4,000 & A3 & & A2 & 25,000 \\
\hline LL-13 & $\mathrm{A} 1$ & $96 \mathrm{~J}$ & A2 & 4,000 & A3 & & A2 & 10,000 \\
\hline$L L-14$ & $\mathrm{~A} 2$ & 5,750 & & & A3 & & A3 & 10,000 \\
\hline$L L-15$ & $\mathrm{~A} 2$ & 20,403 & $\cdot$ & & B1 & & A3 & \\
\hline LL-16 & B1 & & & & $\mathrm{B} 1$ & & A3 & \\
\hline LL-17 & A2 & 10,800 & & & $\mathrm{Al}$ & 10,000 & A3 & \\
\hline LL-18 & $\mathrm{A} 2$ & 9,600 & & . & $\mathrm{Al}$ & 12,000 & A3 & \\
\hline LL-19 & $\mathrm{A} 2$ & 7,700 & & & $\mathrm{Al}$ & 10,000 & A3 & \\
\hline LL -20 & A2 & 1,260 & A2 & 6,000 & $\mathrm{~A} 1$ & 12,000 & A3 & \\
\hline LL-21 & A2 & 8,600 & & & A1 & 12,000 & A3 & \\
\hline LL-22 & A2 & 4,300 & A2 & 6,000 & A1 & 12,000 & A3 & \\
\hline
\end{tabular}


Table E.1 (continued)

\begin{tabular}{|c|c|c|c|c|}
\hline \multirow[b]{3}{*}{ Identifier } & \multicolumn{4}{|c|}{ Manufacturer } \\
\hline & \multicolumn{2}{|c|}{ Werthington } & \multicolumn{2}{|c|}{ zimpro, Inc. } \\
\hline & Avallability & $\begin{array}{c}\text { Largest } \\
\text { capacity } \\
(\mathrm{gpm})\end{array}$ & Avallab $\cong$ lity & $\begin{array}{l}\text { Largest } \\
\text { capacity } \\
\text { (gpm) }\end{array}$ \\
\hline LL-1 & $\mathrm{Al}$ & & F1 & 200 \\
\hline$L L-2$ & $\mathrm{~A} 1$ & & F1 & 200 \\
\hline $\mathrm{LL}-3$ & $\mathrm{~A} 1$ & & F1 & 200 \\
\hline$L L-4$ & A2 & & F1 & 200 \\
\hline$L L-5$ & A2 & & F1 & 200 \\
\hline LL-6 & $\mathrm{Al}$ & 22,000 & F1 & 200 \\
\hline $\mathrm{LL}-7$ & A2 & & F1 & 200 \\
\hline LL-8 & A2 & & F1 & 200 \\
\hline$L L-9^{\circ}$ & A2 & 9,000 & Fl & 200 \\
\hline LL-10 & A2 & 9,000 & F1 & 200 \\
\hline LL-11 & A2 & 9,000 & F1 & 200 \\
\hline LL-12 & A2 & 9,000 & F1 & 200 \\
\hline LLL-13 & $\mathrm{A} 2$ & 9,000 & F1 & 200 \\
\hline$L L-14$ & $\mathrm{~B}^{\circ}$ & & F1 & 200 \\
\hline LL-15 & Al & 22,000 & F1 & 200 \\
\hline$L L-16$ & $\mathrm{Bl}$ & 50 & $\mathbf{F} 1$ & 200 \\
\hline LL-17 & Al & 22,000 & F1 & 200 \\
\hline LL-18 & A1 & 22,000 & F1 & 200 \\
\hline LL-19 & $\mathrm{Al}$. & 22,000 & F1 & 200 \\
\hline LL-20 & $\mathrm{Al}$ & 22,000 & A2 & 200 \\
\hline LL-21 & $\mathrm{A} 1$ & 22,000 & F1 & 200 \\
\hline LL-22 & $\mathrm{Al}$ & 20,000 & F1 & 200 \\
\hline
\end{tabular}


Table E.2. Responses from manufacturers to questions on availability and capacity Pumps: ML and MM series

\begin{tabular}{|c|c|c|c|c|c|c|c|c|}
\hline \multirow[b]{3}{*}{ Identifier } & \multicolumn{8}{|c|}{ Manufacturer } \\
\hline & \multicolumn{2}{|c|}{ Barrett, Haentjens \& Ca. } & \multicolumn{2}{|c|}{ Bingham-Willamette Co. } & \multicolumn{2}{|c|}{ Buffalo Forge $\mathrm{Co}$. } & \multicolumn{2}{|c|}{ Byron Jackson } \\
\hline & Availability & $\begin{array}{l}\text { Largest } \\
\text { capacity } \\
\text { (gpm! }\end{array}$ & Availability & $\begin{array}{l}\text { Largest } \\
\text { capacity } \\
(\mathrm{gpm})\end{array}$ & Availability & $\begin{array}{l}\text { Largest } \\
\text { capacity } \\
(\text { gpm })\end{array}$ & Availability & $\begin{array}{l}\text { Largest } \\
\text { capacity } \\
\text { (gpm) }\end{array}$ \\
\hline ML-1 & A2 & & .12 & 3,000 & A3 & & $\mathrm{Al}$ & 2,400 \\
\hline ML-2 & $\mathrm{A} 2$ & & $A 2$ & 6,500 & A 3 & & $\mathrm{~A} 2$ & 9,800 \\
\hline ML-3 & $\mathrm{A2}$ & & .12 & 7,500 & A3 & & $\mathrm{Al}$ & 650 \\
\hline ML-4 & A2 & & 12 & 7,500 & $\mathrm{~A} 3$ & & $\mathrm{Al}$ & 330 \\
\hline ML-5 & $\mathrm{A} 2$ & & 72 & 7,500 & $\mathrm{~A} 3$ & & Al & 700 \\
\hline MI-6 & $\mathrm{A} 2$ & & 42 & 22,500 & $\mathrm{~A} 3$ & & $\mathrm{~A} 2$ & 10,500 \\
\hline ML-7 & $\mathrm{A} 2$ & & $\$ 2$ & 26,000 & $\mathrm{~A} 3$ & & $\mathrm{~A} 2$ & 27,000 \\
\hline M1-8 & A2 & & A2 & 32,000 & A3 & & & \\
\hline ML-9 & A2 & & $A 2$ & 26,000 & A3 & & & \\
\hline ML-10 & $\mathrm{A} 2$ & & B1 & & A3 & & & \\
\hline$M M-1$ & $\mathrm{~A} 2$ & & A2 & $\begin{array}{l}13,000 \\
11,000\end{array}$ & A3 & & A2 & 6,500 \\
\hline MM-2 & A2 & & $A 2$ & $\begin{array}{r}9,000 \\
16,000\end{array}$ & A3 & & $\mathrm{A} 2$ & 7,000 \\
\hline MM-3 & $\mathrm{A} 2$ & & A2: & $\begin{array}{r}9,000 \\
16,000\end{array}$ & A3 & . & $\mathrm{A} 2$ & 9,000 \\
\hline MM-4 & $\mathrm{A} 2$ & & $\mathrm{~A} 2$ & $\begin{array}{r}8,000 \\
16,000\end{array}$ & A3 & & $\mathrm{A} 2$ & 1,460 \\
\hline$M M-5$ & $\mathrm{~A} 2$ & & $\mathrm{~A} 2$ & 16,000 & A3 & . & $\mathrm{A} 2$ & 8,400 \\
\hline$M-6$ & $\mathrm{~A} 2$ & $\cdots$ & $A \hat{2}$ & 16,000 & A3 & $\cdot$ & $\mathrm{A} 2$ & 19,000 \\
\hline$M M-7$ & ${ }^{\mathrm{A} 2}$ & . & A2 & 12,000 & A3 & & $\mathrm{A} 2$ & 9,000 \\
\hline$M M-8$ & $\mathrm{~A} 2$ & & $\mathrm{~A} 3, \mathrm{Cl}$ & $\cdot$ & A3 & & & \\
\hline & $\cdots$ & & & $\cdots$ & & & & \\
\hline
\end{tabular}


Table E. 2 (continued!

\begin{tabular}{|c|c|c|c|c|c|c|c|c|}
\hline \multirow[b]{3}{*}{ Identifier } & \multicolumn{8}{|c|}{ Manufacturer } \\
\hline & \multicolumn{2}{|c|}{$\begin{array}{l}\text { Colt Industries } \\
\text { Fairbanks Morse }\end{array}$} & \multicolumn{2}{|c|}{$\begin{array}{l}\text { Delaval IMO } \\
\text { Division }\end{array}$} & \multicolumn{2}{|c|}{$\begin{array}{l}\text { Delava1 Turbine } \\
\text { Divisior: }\end{array}$} & \multicolumn{2}{|c|}{ Dover Corp. } \\
\hline & Avaflability & $\begin{array}{l}\text { Largest } \\
\text { capacity } \\
\text { (gpm) }\end{array}$ & 'Availability & $\begin{array}{l}\text { Largest } \\
\text { capacity } \\
\text { (gpm) }\end{array}$ & Availability & $\begin{array}{c}\text { Largest } \\
\text { capacity } \\
\text { (gpm) }\end{array}$ & Availability & $\begin{array}{c}\text { Largest } \\
\text { capacity } \\
(\mathrm{gpm})\end{array}$ \\
\hline ML-1 & & & 4.3 & & A3 & & & \\
\hline ML-2 & & & 83 & & A3 & & & \\
\hline $\mathrm{ML}-3$ & & & A3 & & A3 & & & \\
\hline ML-4 & & & A3 & & A3 & & & \\
\hline ML-5 & & & A2 & 560 & A3 & & & \\
\hline MI -6 & . & & $A 2$ & 560 & A3 & & & \\
\hline ML 7 & & & $\mathrm{~A} 2$ & 560 & A3 & & & \\
\hline ML-8 & & & $\mathrm{A} 3$ & & A3 & & & \\
\hline ML-9 & & & A3 & & A3 & & & \\
\hline$M L-10$ & & & A.3 & & A3 & & & \\
\hline MM-1 & & & A3 & & $A 3, \quad B 1$ & & & \\
\hline$M-1$ & $A=$ & 4,500 & Ab & & $\mathrm{A} 3, \mathrm{~B} 1$ & & & \\
\hline MM-3 & Az & 9,000 & A3 & & $\mathrm{A} 3, \mathrm{~B} 1$ & & $\cdot$ & \\
\hline$M M-4$ & A2 & 1,300 & $A 3$ & & A3 & & & \\
\hline$M M-5$ & & & $A:$ & & A3 & & & \\
\hline$M M-6$ & & & $A=$ & & A3 & & · & \\
\hline MM-7 & & & $A \tilde{L}$ & 9,600 & & & & \\
\hline MM-8 & & & $\mathrm{c} 2$ & & & & & \\
\hline
\end{tabular}


Table E.2 (continued)

\begin{tabular}{|c|c|c|c|c|c|c|c|c|}
\hline \multirow[b]{3}{*}{ Identifier } & \multicolumn{8}{|c|}{ Manufacturer } \\
\hline & \multicolumn{2}{|c|}{$\begin{array}{l}\text { Dresser Industries } \\
\text { Pacific Pump }\end{array}$} & \multicolumn{2}{|c|}{ The Duriron Co., Inc. } & \multicolumn{2}{|c|}{ Galigher Co. } & \multicolumn{2}{|c|}{$\begin{array}{l}\text { Ingersoll-Rand Co. } \\
\text { Cameron Pump Division }\end{array}$} \\
\hline & Atallability & $\begin{array}{l}\text { Largest } \\
\text { capacity } \\
(\mathrm{gpm})\end{array}$ & Availabilfty & $\begin{array}{l}\text { Largest } \\
\text { capacity } \\
\text { (gpm) }\end{array}$ & Availability & $\begin{array}{l}\text { Largest } \\
\text { capacity } \\
\text { (gpm) }\end{array}$ & Availability & $\begin{array}{l}\text { Largest } \\
\text { capacity } \\
(\mathrm{gpm})\end{array}$ \\
\hline ML-1 & $\mathrm{A} 2$ & 16,000 & A3 & & A3 & & $A 1, A 2$ & as req' $\mathrm{d}$. \\
\hline ML-2 & A2 & 16,000 & 43 & & A3 & & $\mathrm{A} 1, \mathrm{~A} 2$ & as req' $\mathrm{d}$. \\
\hline $\mathrm{ML}-3$ & $A 2$ & 16,000 & A3 & & $\mathrm{A} 1$ & 1,200 & $\mathrm{~A} 1, \mathrm{~A} 2$ & as req'd. \\
\hline $\mathrm{ML}-4$ & $\mathrm{~A} 2$ & 16,000 & 43 & & A3 & & $\mathrm{Al}, \mathrm{A} 2$ & as req'd. \\
\hline$M L-5$ & $\mathrm{~A} 2$ & 16,000 & A3 & . & $\mathrm{Al}$ & 1,200 & $\mathrm{~A} 1, \mathrm{~A} 2$ & 14,000 \\
\hline$M L-6$ & A2 & 16,000 & 43 & & A3 & & $A 1, \quad A 2$ & 14,000 \\
\hline $\mathrm{ML}-7$ & $\mathrm{C} 1$ & 32,000 & A3 & & A3 & & B1 & 8,000 \\
\hline ML-8 & A2 & 16,000 & A3 & & A3 & & $\mathrm{B} 1, \mathrm{~B} 2$ & 15,000 \\
\hline ML-9 & $\mathrm{A} 2$ & 16,000 & A3 & & A3 & & A3 & 15,000 \\
\hline $\mathrm{ML}-10$ & $\mathrm{~A} 2$ & 32,000 & B1 & & A3 & & A3. & 15,000 \\
\hline$M M-1$ & $\mathrm{~A} 2$ & 16,000 & A3 & & A3 & & A2 & 14,000 \\
\hline $\mathrm{MM}-2$ & A2 & 9,500 & A3 & & A3 & & A3 & 14,000 \\
\hline$M M-3$ & $\mathrm{~A} 2$ & 9,500 & A3 & & A3 & & A3 & 14,000 \\
\hline$M M-4$ & $\mathrm{~A} 2$ & 16,000 & A3 & & A3 & . & $A 2, A 3$ & 14,000 \\
\hline$M M-5$ & $\mathrm{~A} 2$ & 16,000 & A3 & & A3 & & $A 2, A 3$ & 14,000 \\
\hline$M M-6$ & A2 & 16,000 & A3 & & A3 & & $A 2, A 3$ & 14,000 \\
\hline$M M-7$ & A2 & 16,000 & A3 & & 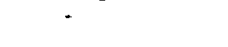 & & $\mathrm{A} 2, \mathrm{~A} 3$ & 14,000 \\
\hline$M M-8$ & B1 & 16,000 & A3 & & A3 & & $\mathrm{C} 3, \mathrm{C} 4$ & \\
\hline
\end{tabular}


Table E.2 (continued)

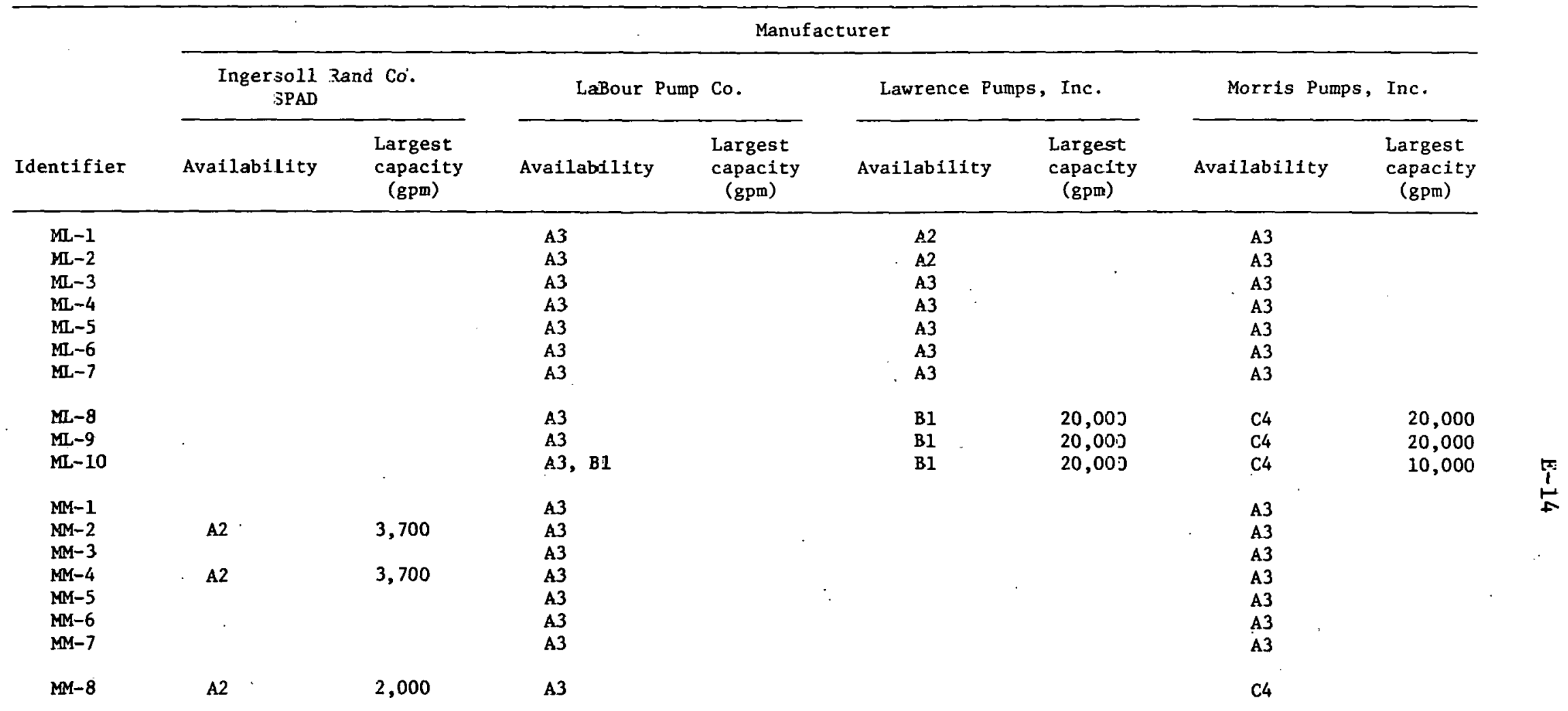


Table E. 2 (continued)

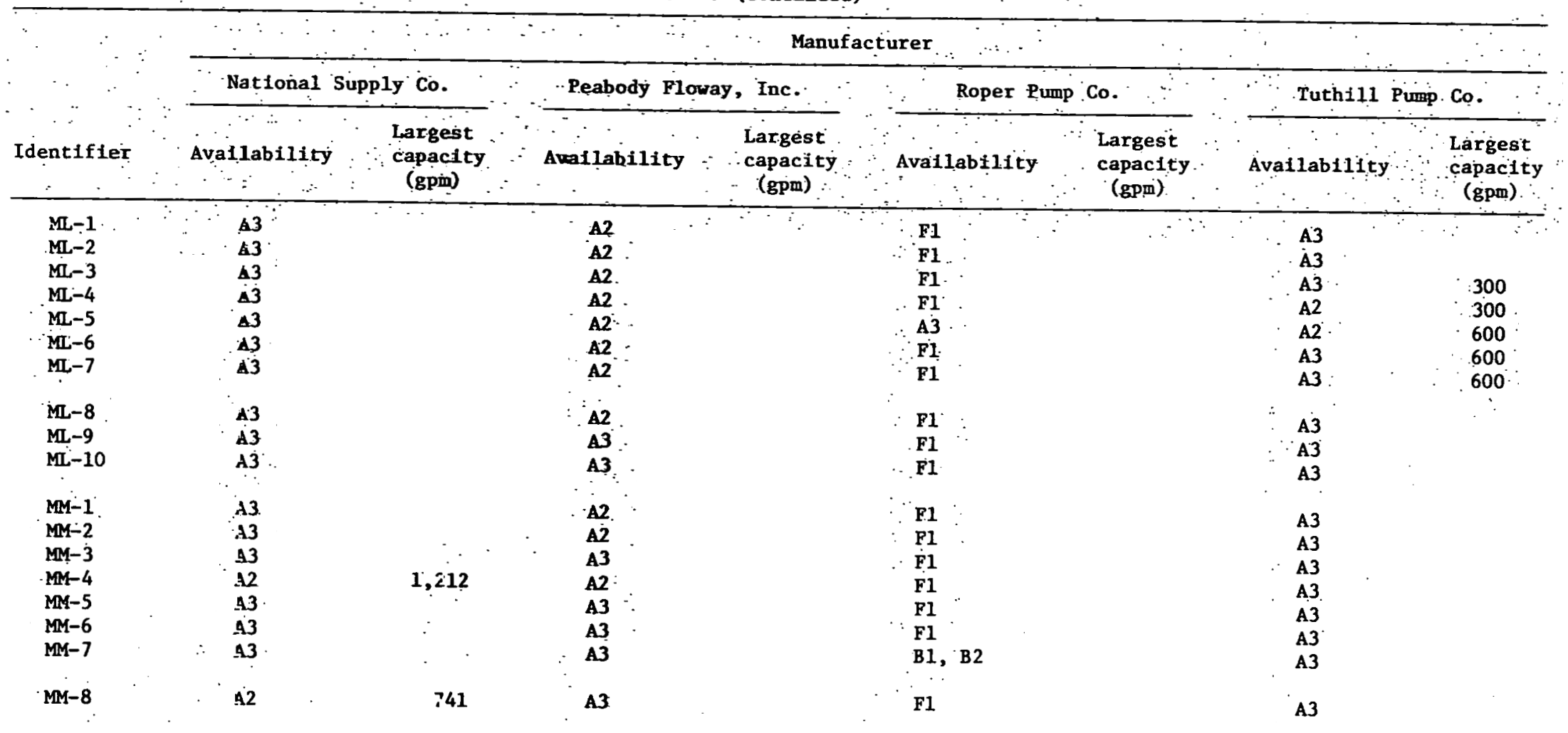


Table E. 2 (continued)

\begin{tabular}{|c|c|c|c|c|c|c|c|c|}
\hline \multirow{3}{*}{ Identifier } & & & \multicolumn{4}{|c|}{ Manufiacturer } & \multicolumn{2}{|l|}{. } \\
\hline & \multicolumn{2}{|c|}{ United } & \multicolumn{2}{|c|}{ Warren Pumps, Inc. } & \multicolumn{2}{|c|}{ Wilfley } & \multicolumn{2}{|c|}{ Wilson-Snyder Pumps } \\
\hline & Availability & $\begin{array}{l}\text { Largest } \\
\text { capacity } \\
\text { (gpm) }\end{array}$ & Availability & $\begin{array}{l}\text { Largest } \\
\text { capacity } \\
(\mathrm{gPm})\end{array}$ & Availability & $\begin{array}{l}\text { Largest } \\
\text { capacity } \\
(\mathrm{gpm})\end{array}$ & Availability & $\begin{array}{l}\text { Largest } \\
\text { capacity } \\
\text { (gpm) }\end{array}$ \\
\hline ML-1 & Al & 1,800 & & & A3 & & A2 & 10,000 \\
\hline $\mathrm{ML}-2$ & Al & 7,000 & & & A3 & & A2 & 10,000 \\
\hline $\mathrm{ML}-3$ & A1 & 530 & & & A3 & & A2 & 10,000 \\
\hline ML-4 & A.I & 360 & & & A3 & & $\mathrm{A} 2$ & 25,000 \\
\hline$M L-5$ & AI & 750 & \$2 & 4,000 & A3 & & A2 & 25,000 \\
\hline ML-6 & $\mathrm{B} \bar{E}$ & & & & A3 & & A3. & 10,000 \\
\hline$M L-7$ & $\mathbf{B i}$ & & & & A3 & & A3 & 10,000 \\
\hline ML-8 & B1 & & & & B2 & & A3 & \\
\hline ML-9 & B1 & & & & B2 & & A3 & \\
\hline ML-10 & $A=$ & 6,000 & & & $\mathrm{Cl}$ & & A3 & \\
\hline$M-1$ & Al & 7,200 & & & A3 & & A3 & 25,000 \\
\hline$M M-2$ & $\mathrm{Al}$ & 5,400 & & & A3 & & A3 & 25,000 \\
\hline$M M-3$ & A2 & 10,800 & & & A3 & & A3 & 25,000 \\
\hline$M M-4$ & Al & 1,560 & $\cdot$ & & A3 & & A2 & 25,000 \\
\hline$M M-5$ & Al & 9,600 & & & & & A3 & $.25,000$ \\
\hline$M M-6$ & $\mathrm{B1}$ & & & & & & A3 & 25,000 \\
\hline $\mathbb{M}-7$ & Al & 8,600 & & & & & A3 & 10,000 \\
\hline MM-8 & A2 & 840 & & & $\mathrm{~A} 3$ & & A2 & 3,200 \\
\hline
\end{tabular}


Table E.2 (ccntinued)

\begin{tabular}{|c|c|c|c|c|}
\hline \multirow[b]{3}{*}{ Identifier } & \multicolumn{4}{|c|}{ Manufacturer } \\
\hline & \multicolumn{2}{|c|}{ Worthington } & \multicolumn{2}{|c|}{ Zimpro, Inc. } \\
\hline & Availlability & $\begin{array}{l}\text { Largest } \\
\text { capacity } \\
\text { (gpm) }\end{array}$ & Arailability & $\begin{array}{c}\text { Largest } \\
\text { capacity } \\
\text { (gpm) }\end{array}$ \\
\hline ML-1 & & & F1 & 200 \\
\hline $\mathrm{ML}-2$ & & & $\mathrm{Fl}$ & 200 \\
\hline ML-3 & & & $\mathrm{A} 2$ & 200 \\
\hline $\mathrm{ML}-4$ & & & $\mathrm{~A} 2$ & 200 \\
\hline ML-5 & A2 & $9,(100$ & F1 & 200 \\
\hline ML-6 & A2 & 9,000 & Fl & 200 \\
\hline ML-7 & $\mathrm{A} 2$ & 9,000 & F1 & 200 \\
\hline ML-8 & B1 & 22,000 & F1 & 200 \\
\hline ML-9 & $\mathrm{BI}$ & 22,000 & F1 & 200 \\
\hline $\mathrm{ML}-10$ & $\mathrm{~B} 1$ & 22,000 & $\mathrm{~F} 1$ & 200 \\
\hline MM-1 & & & FI & 200 \\
\hline MM-2 & & & $\mathrm{Fl}$ & 200 \\
\hline$M M-3$ & & & FI & 200 \\
\hline$M M-4$ & & & A2 & 200 \\
\hline$M M-5$ & & & F1 & 200 \\
\hline$M M-6$ & & & F1 & 200 \\
\hline MM-7 & $\mathrm{A} 2$ & 9,300 & F1 & 200 \\
\hline MM-8 & $\mathrm{Cl}$ & & A2 & 200 \\
\hline
\end{tabular}


Tajle E.3. Responses from mantfacturers to questions on availability and capacity

Pumps: HL and HH series

\begin{tabular}{|c|c|c|c|c|c|c|c|c|}
\hline \multirow[b]{3}{*}{ Identifier } & \multicolumn{8}{|c|}{ Manufacturer } \\
\hline & \multicolumn{2}{|c|}{ Barrett, Haentjens \& Co. } & \multicolumn{2}{|c|}{ Bingham-Willamette Co. } & \multicolumn{2}{|c|}{ Buffalo Forge Co. } & \multicolumn{2}{|c|}{ Byron Jackson } \\
\hline & Availability & $\begin{array}{l}\text { Largest } \\
\text { capacity } \\
\text { (gpm) }\end{array}$ & Availability & $\begin{array}{l}\text { Largest } \\
\text { capacity } \\
\text { (gpm) }\end{array}$ & Availability & $\begin{array}{l}\text { Largest } \\
\text { capacity } \\
\text { (gpm) }\end{array}$ & Availability & $\begin{array}{l}\text { Largest } \\
\text { capacity } \\
\text { (gpm) }\end{array}$ \\
\hline $\begin{array}{l}\mathrm{HL}-1 \\
\mathrm{HL}-2\end{array}$ & $A \overline{2}$ & & $\begin{array}{l}A 2 \\
A 2\end{array}$ & 10,500 & A3 & & $\mathrm{A} 2$ & 6,700 \\
\hline & & & & 10,000 & A3 & & A2 & 10,000 \\
\hline $\mathrm{HL}-3$ & & & A2 & 22,500 & A3 & & & \\
\hline HH-1 & & & $\mathrm{A}^{2}$ & $\begin{array}{r}4,000 \\
10,000\end{array}$ & A3 & & $\mathrm{A} 2$ & 4,000 \\
\hline $\mathrm{HH}-2$ & & & $A ?$ & $\begin{array}{l}4,500 \\
7,000\end{array}$ & A3 & & $\mathrm{A} 2$ & 4,700 \\
\hline $\mathrm{HH}-3$ & & & $\mathrm{~B} \perp$ & 16,000 & .13 & & A2 & 18,000 \\
\hline $\mathrm{HH}-4$ & & & A.3 & & 13 & & B1 & \\
\hline HH-5 & A2 & & $A ?$ & $\begin{array}{r}5,500 \\
14,000\end{array}$ & $A 3$ & & $\mathrm{~A} 2$ & 4,100 \\
\hline $\mathrm{HH}-5$ & & & $\mathrm{~B}_{2}^{-}$ & $\begin{array}{l}16,000 \\
14,000\end{array}$ & $\Delta 3$ & & $\mathrm{~A} 2$ & 1,500 \\
\hline $\mathrm{HH}-7$ & & & $\mathrm{~A} \tilde{2}$ & 6,500 & $\Delta 3$ & . & A2 & 15,000 \\
\hline $\mathrm{HH}-8$ & & & $A \tilde{a}$ & 6,500 & $\Delta 3$ & & $\mathrm{~A} 2$ & 5,500 \\
\hline $\mathrm{HH}-9$ & & & $D_{c}^{\prime}$ & & f. 3 & & & \\
\hline $\mathrm{HH}-10$ & & & $\mathrm{D} 2$ & & $\& 3$ & & & \\
\hline HH-11 & & & $\mathrm{D} \bar{z}$ & & f.3 & & & \\
\hline HH-12 & & & $\mathrm{D} 2$ & & 33 & & & \\
\hline $\mathrm{HH}-13$ & A. 2 & & $D 2$ & & A 3 & & & \\
\hline $\mathrm{HH}-14$ & A.2 & & D2 & & A3 & & & \\
\hline
\end{tabular}


Table E. 3 (continued)

\begin{tabular}{|c|c|c|c|c|c|c|c|c|}
\hline \multirow[b]{3}{*}{ Identifier } & \multicolumn{8}{|c|}{ Manufacturer } \\
\hline & \multicolumn{2}{|c|}{$\begin{array}{l}\text { Cole Industries } \\
\text { Fairbanks Morse }\end{array}$} & \multicolumn{2}{|c|}{$\begin{array}{c}\text { Delaval IMO } \\
\text { Division }\end{array}$} & \multicolumn{2}{|c|}{$\begin{array}{c}\text { Delaval Turbine } \\
\text { Division }\end{array}$} & \multicolumn{2}{|c|}{ Dover Corp. } \\
\hline & Availability & $\begin{array}{l}\text { Largest } \\
\text { capacity } \\
(\text { gpm) }\end{array}$ & Availability & $\begin{array}{l}\text { Largest } \\
\text { capacity } \\
\text { (gpm) }\end{array}$ & Availability & $\begin{array}{c}\text { Largest } \\
\text { capacity } \\
\text { (gpm) }\end{array}$ & Availability & $\begin{array}{c}\text { Largest } \\
\text { capacity } \\
(\text { gpm) }\end{array}$ \\
\hline $\mathrm{HL}-1$ & & & A3 & & A3 & & & \\
\hline $\mathrm{HL}-3$ & & & A3 & & & & & \\
\hline $\mathrm{HH}-1$ & & & A3 & & $\mathrm{A} 3, \mathrm{~B} 1$ & & & \\
\hline $\mathrm{HH}-2$ & & & A3 & & $A 3, B 1$ & & . & \\
\hline $\mathrm{HH}-5$ & & & A3 & & B1 & & & \\
\hline $\mathrm{HH}-4$ & & & A3 & & $\mathrm{B} 1$ & & & \\
\hline $\mathrm{HH}-5$ & & & A3 & & A3 & & & \\
\hline$H H-6$ & & & A3 & & $\mathrm{A} 3, \mathrm{~B} 1$ & & & \\
\hline $\mathrm{HH}-9$ & & & A3 & & $A 3, B 1$ & & & \\
\hline HH-10 & & & E1 & & & & & \\
\hline $\mathrm{HH}-11$ & & & EI & & & & & \\
\hline $\mathrm{HH}-12$ & & & $\mathrm{D} 2$ & & & & & \\
\hline $\mathrm{HH}-13$ & & & D2 & & & & & \\
\hline $\mathrm{HH}-14$ & & & $\mathrm{D} 2$ & & & & & \\
\hline
\end{tabular}


Table E. 3 (continued)

\begin{tabular}{|c|c|c|c|c|c|c|c|c|}
\hline \multirow[b]{3}{*}{ Identifier } & \multicolumn{8}{|c|}{ Manufacturer } \\
\hline & \multicolumn{2}{|c|}{$\begin{array}{c}\text { Dresser Industries } \\
\text { Pacific Pump }\end{array}$} & \multicolumn{2}{|c|}{ The Iuriron Co., Inc. } & \multicolumn{2}{|c|}{ Galigher Cc. } & \multicolumn{2}{|c|}{$\begin{array}{l}\text { Ingersoll Rand Co. } \\
\text { Cameron Pump Division }\end{array}$} \\
\hline & Availability & $\begin{array}{l}\text { Largest } \\
\text { capacity } \\
\text { (gpm) }\end{array}$ & Availability & $\begin{array}{l}\text { Largest } \\
\text { capacity } \\
\text { (gpm) }\end{array}$ & Availability & $\begin{array}{l}\text { Largest } \\
\text { capacity } \\
(\text { gpm) }\end{array}$ & Availability & $\begin{array}{l}\text { Largest } \\
\text { capacity } \\
(\mathrm{gpm})\end{array}$ \\
\hline HL-1 & A2 & 12,000 & A3 & & A3 & & A 3 & 14,000 \\
\hline $\mathrm{HL}-2$ & $\mathrm{~A} 2$ & 12,000 & $\mathrm{~A} 3$ & & A3 & & A3 & 14,000 \\
\hline $\mathrm{HL}-3$ & B1 & 12,000 & $\mathrm{~A} 3$ & & A3 & & $\mathrm{C} 3, \mathrm{C} 4$ & \\
\hline $\mathrm{HH}-1$ & $\mathrm{~A} 2$ & 20,000 & $A 3$ & & A3 & & A2 & \\
\hline $\mathrm{HH}-2$ & A2 & 20,000 & $A 3$ & & A3 & & $\mathrm{A} 3, \mathrm{BI}$ & \\
\hline $\mathrm{HH}-3$ & A2 & 20,000 & A3 & & A3 & & $\mathrm{A} 3, \mathrm{~B} 1$ & \\
\hline $\mathrm{HH}-4$ & $\mathrm{~B} 1$ & 36,000 & A3 & & A3 & & $\mathrm{A} 3, \mathrm{~B} 1$ & \\
\hline HH -5 & $\mathrm{~A} 2$ & 20,000 & 2.3 & & A3 & & A2 & \\
\hline $\mathrm{HH}-6$ & $\mathrm{~A} 2$ & 32,000 & A.3 & & A3 & & A2. & \\
\hline $\mathrm{HH}-7$ & $\mathrm{~A} 2$ & 20,000 & E.3 & & A3 & . & $\mathrm{A} 2, \mathrm{~A} 3$ & \\
\hline HH-8 & $\mathrm{A} 2$ & 20,000 & 6.3 & & A3 & & $\mathrm{A} 2, \mathrm{~A} 3$ & \\
\hline $\mathrm{HH}-9$ & $A \geq$ & 20,000 & , 33 & & A3 & & $c 3, C_{4}$ & \\
\hline $\mathrm{HH}-10$ & $A \hat{c}$ & 20,000 & $\Delta 3$ & & A3 & & $\mathrm{C} 3, \mathrm{C} 4$ & \\
\hline HH-11 & $\mathrm{A} \bar{i}$ & 36,000 & $\Delta 3$ & & A3 & & . $\mathrm{C} 3, \mathrm{C} 4$ & \\
\hline $\mathrm{HH}-12$ & $\mathrm{~A} 2$ & 20,000 & A3 & & A3 & & $\mathrm{C} 3, \mathrm{C} 4$ & \\
\hline $\mathrm{HH}-13$ & A2 & 20,000 & .13 & & A3 & & $\mathrm{C} 3, \mathrm{C} 4$ & \\
\hline $\mathrm{HH}-14$ & A2 & 20,000 & 13 & & A3 & & $\mathrm{C} 3, \mathrm{C} 4$ & \\
\hline
\end{tabular}


Table E.3 (continued)

\begin{tabular}{|c|c|c|c|c|c|c|c|c|}
\hline \multirow[b]{3}{*}{ Identifier } & \multicolumn{8}{|c|}{ Manufacturer } \\
\hline & \multicolumn{2}{|c|}{$\begin{array}{l}\text { Ingersoll Rand Co. } \\
\text { SPAD }\end{array}$} & \multicolumn{2}{|c|}{ LaBour Pump Co. } & \multicolumn{2}{|c|}{ Lawrence Pumps, Inc. } & \multirow[t]{2}{*}{ Morris Pumps, } & \multirow{2}{*}{$\begin{array}{l}\text { Inc. } \\
\begin{array}{l}\text { Largest } \\
\text { capacity } \\
(\text { gpm) }\end{array}\end{array}$} \\
\hline & Availability & $\begin{array}{c}\text { Largest } \\
\text { capacity } \\
\text { (gpm! }\end{array}$ & Availability & $\begin{array}{l}\text { Largest } \\
\text { capacity } \\
(\mathrm{gpm})\end{array}$ & Availability & $\begin{array}{c}\text { Largest } \\
\text { capacity } \\
(\mathrm{gpm})\end{array}$ & & \\
\hline $\mathrm{HL}-1$ & & & A3 & & $\mathrm{BI}$ & 10,000 & A3 & \\
\hline $\mathrm{HL}-2$ & & & A3 & & $\mathrm{B} 1$ & 1,000 & A3 & \\
\hline $\mathrm{HL}-3$ & & & A3 & & A3 & & $\mathrm{C} 4$ & \\
\hline $\mathrm{HH}-1$ & A2 & 3,700 & A3 & & A3 & & . A3 & \\
\hline $\mathrm{HH}-2$ & . & & A3 & & A3 & & A3 & \\
\hline $\mathrm{HH}-3$ & & & A3 & & A3 & & A3 & \\
\hline $\mathrm{HH}-4$ & & & A3 & & A3 & & A3 & \\
\hline $\mathrm{HH}-5$ & $A ?$ & $3,7 \mathrm{CO}$ & A3 & & A3 & & A3 & \\
\hline $\mathrm{HH}-6$ & . & & A3 & & A3 & . & A3 & \\
\hline $\mathrm{HH}-7$ & $A \underline{?}$ & $3,7 \cdot 0 \cdot 0$ & A3 & & A3 & & A3 & \\
\hline $\mathrm{HH}-8$ & & & A3 & & A3 & & A3 & \\
\hline $\mathrm{HH}-9$ & $\mathrm{~A} 2$ & 3,7010 & A3 & & A3 & & $\cdot \mathrm{C}_{4}$ & \\
\hline $\mathrm{HH}-10$ & A2 & 650 & $\mathrm{~F} 1$ & & $\mathrm{C4}$ & & $\mathrm{C} 4$ & \\
\hline HH-11 & A2 & 650 & $\mathrm{~F} 1$ & & A3 & & C4 & \\
\hline $\mathrm{HH}-12$ & A2 & 2,400 & $\mathrm{Fl}$ & & $\mathrm{C} 4$ & & $\mathrm{C} 4$ & \\
\hline $\mathrm{HH}-13$ & A2 & 2,400 & F1 & & $\mathrm{C4}$ & & $\mathrm{C} 4$ & \\
\hline $\mathrm{HH}-14$ & A2 & 2,400 & F1 & & $\mathrm{C} 4$ & & $\mathrm{C} 4$ & \\
\hline
\end{tabular}


Table E. 3 (continued)

\begin{tabular}{|c|c|c|c|c|c|c|c|c|c|}
\hline \multirow[b]{3}{*}{ Identifier } & \multicolumn{9}{|c|}{ Manufacturer } \\
\hline & \multicolumn{2}{|c|}{ National Supply Co. } & \multicolumn{2}{|c|}{ Peabjdy Floway, Inc. } & \multicolumn{2}{|c|}{ Roper Pump $\mathrm{C}_{2}$. } & \multicolumn{2}{|c|}{ Tuthill Pump } & \multirow{2}{*}{$\begin{array}{l}\text { Co. } \\
\begin{array}{c}\text { Largest } \\
\text { capacity } \\
\text { (gpm) }\end{array}\end{array}$} \\
\hline & Availability & $\begin{array}{l}\text { Largest } \\
\text { capacity } \\
\text { (gpm) }\end{array}$ & Availability & $\begin{array}{l}\text { Largest } \\
\text { capacity } \\
\text { (gpm) }\end{array}$ & Availability & $\begin{array}{l}\text { Largest } \\
\text { capacity } \\
(\text { gpm })\end{array}$ & Availability & & \\
\hline $\mathrm{HL}-1$ & A3 & & $A 2$ & & F1 & & A3 & & \\
\hline $\mathrm{HL}-2$ & A3 & & $A 2$ & & F1 & & A3 & & \\
\hline $\mathrm{HL}-3$ & A3 & & A. 2 & & $\mathrm{~F} 1$ & & & & \\
\hline $\mathrm{HH}-1$ & A2 & 1,204 & A3 & & $\mathrm{F} 1$ & & A3 & & \\
\hline $\mathrm{HH}-2$ & A2 & 1,195 & A3 & & $\mathrm{F} 1$ & & A3 & & \\
\hline $\mathrm{HH}-3$ & $\mathrm{~A} 2$ & 1,026 & A3 & & F1 & & & & \\
\hline $\mathrm{HH}-4$ & A2 & 1,026 & A3 & & F1 & & & & \\
\hline $\mathrm{HH}-5$ & $\mathrm{~A} 2$ & 1,195 & A3 & & F1 & & A3 & & \\
\hline HH-6 & A2 & 1,195 & A3 & & $\mathrm{Fl}$ & & A3 & & \\
\hline $\mathrm{HH}-7$ & A2 & 435 & A3 & & FI & & & & \\
\hline $\mathrm{HH}-9$ & A2 & 435 & $\mathrm{~A} 3$ & & F1 & & & & \\
\hline $\mathrm{HH}-9$ & A2 & 972 & A3 & & F1 & & . & & \\
\hline $\mathrm{HH}-10$ & BI & 400 & A3 & & F1 & & & & \\
\hline $\mathrm{HH}-11$ & B1 & 400 & A3 & & F1 & & & & \\
\hline HH-12 & & & A3 & & F1 & & & & \\
\hline $\mathrm{HH}-13$ & $\mathrm{~A} 2$ & 1,195 & A3 & & FI & & & & \\
\hline $\mathrm{HH}-14$ & A2 & 1,195 & A3 & & Fi & & & & \\
\hline
\end{tabular}


Table E. 3 (continued)

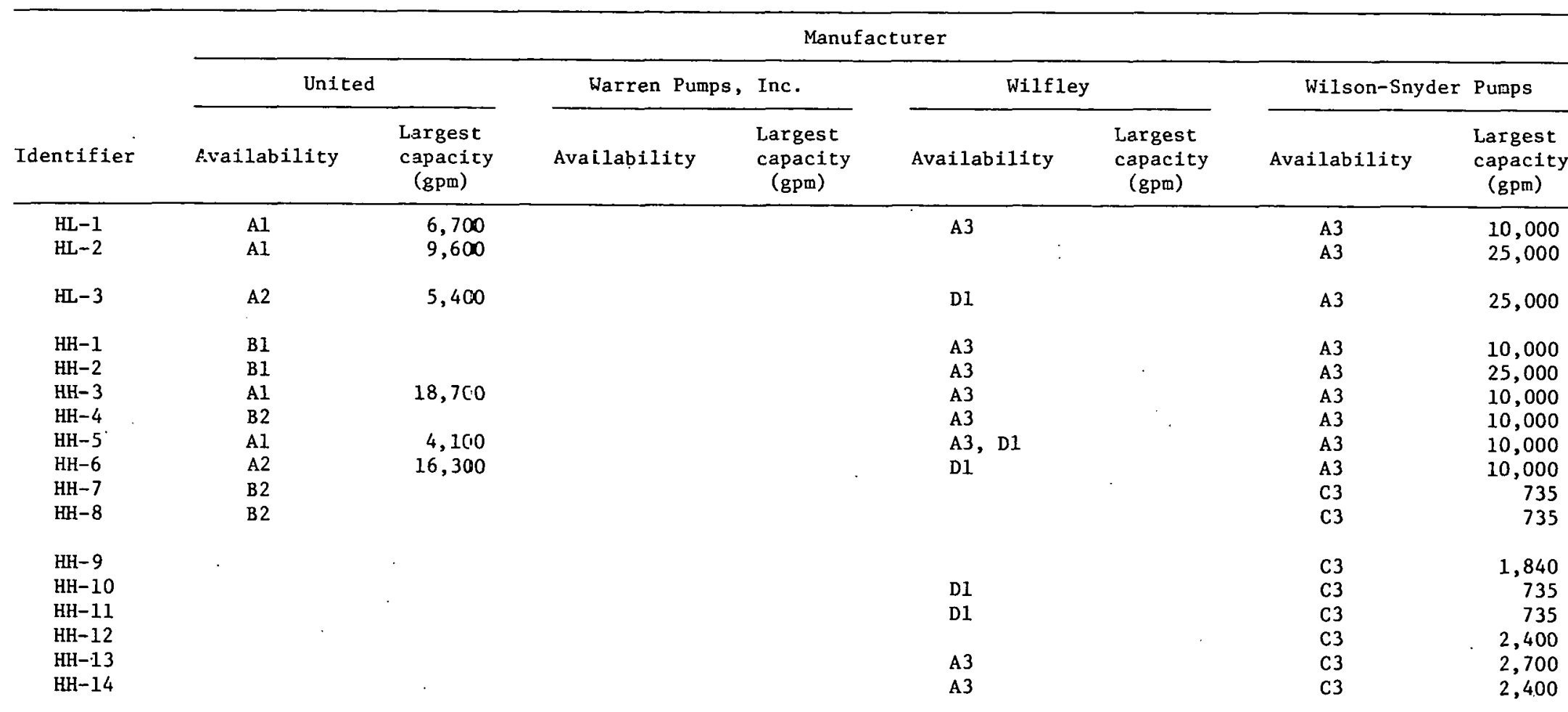


Table E. 3 (continued)

\begin{tabular}{|c|c|c|c|c|}
\hline \multirow[b]{3}{*}{ Identifier } & \multicolumn{4}{|c|}{ Manufacturer } \\
\hline & \multicolumn{2}{|c|}{ Worthington } & \multicolumn{2}{|c|}{ Zimpro, Inc. } \\
\hline & Availability & $\begin{array}{l}\text { Largest } \\
\text { capacity } \\
(\mathrm{gpm})\end{array}$ & Availability & $\begin{array}{l}\text { Largest } \\
\text { capacity } \\
(\mathrm{gpm})\end{array}$ \\
\hline $\mathrm{HL}-1$ & & & F $\mathbb{1}$ & 200 \\
\hline $\mathrm{HL}-2$ & & & FI & 200 \\
\hline $\mathrm{HL}-3$ & $\mathrm{Cl}$ & & $F 1$ & 200 \\
\hline $\mathrm{HH}-1$ & & & $\mathrm{Fl}$ & 200 \\
\hline $\mathrm{HH}-2$ & & & $\mathrm{~F} 1$ & 200 \\
\hline $\mathrm{HH}-3$ & . & & $\mathrm{El}$ & 200 \\
\hline $\mathrm{HH}-4$ & & & F1 & 200 \\
\hline $\mathrm{HH}-5$ & & & $\mathrm{~F} 1$ & 200 \\
\hline HH- 6 & & & F1 & 200 \\
\hline $\mathrm{HH}-7$ & & & F1 & 200 \\
\hline $\mathrm{HH}-8$ & & & $\mathrm{~F} 1$ & 200 \\
\hline $\mathrm{HH}-9$ & & & $\mathrm{~F} 1$ & 200 \\
\hline $\mathrm{HH}-10$ & . & & FI & 200 \\
\hline HH-11 & & & Fl & 200 \\
\hline $\mathrm{HH}-12$ & & & $\mathrm{~F} 1$ & 200 \\
\hline $\mathrm{HH}-13$ & & & Fl & 200 \\
\hline $\mathrm{IH}-\mathrm{i4}$ & & & F1 & 200 \\
\hline
\end{tabular}


Table E.4. Resfonses fror manufacturers to questions on availability and capacity Compressors: FB, L, ML, and, MH series

\begin{tabular}{|c|c|c|c|c|c|c|c|c|}
\hline \multirow[b]{3}{*}{ Identifier } & \multicolumn{8}{|c|}{ Manufacturer } \\
\hline & \multicolumn{2}{|c|}{ Aïrco Cryogenics } & \multicolumn{2}{|c|}{ E.llis-Chalmers Corp. } & \multicolumn{2}{|c|}{ Anerican Demag Corp. } & \multicolumn{2}{|c|}{ Beloit } \\
\hline & Availability & $\begin{array}{l}\text { Largest. } \\
\text { capacity } \\
(\text { acfm) }\end{array}$ & Availability & $\begin{array}{l}\text { Largest } \\
\text { capacity } \\
(\operatorname{acf} m)\end{array}$ & Availability & $\begin{array}{l}\text { Largest } \\
\text { capacity } \\
\text { (acfm) }\end{array}$ & Availability & $\begin{array}{l}\text { Largest } \\
\text { capacity } \\
\quad(\operatorname{acfm})\end{array}$ \\
\hline $\mathrm{FB}-1$ & A3 & & A3 & & $\mathrm{A} 2$ & 720,000 & $\mathbf{F}$ & 25,000 \\
\hline $\mathrm{FB}-2$ & A3 & & A3 & & A2 & 720,000 & $\mathrm{~F}$ & 25,000 \\
\hline FB-3 & A3 & & A3 & & $\mathrm{A} 2$ & 720,000 & $\mathrm{~F}$ & 25,000 \\
\hline $\mathrm{FB}-4$ & A3 & & A3 & & $\mathrm{A} 2$ & 720,000 & $\mathbf{F}$ & 25,000 \\
\hline FB-5 & A3 & & A3 & & $\mathrm{A} 2$ & 720,000 & $\mathrm{~F}$ & 25,000 \\
\hline $\mathrm{FB}-6$ & A3 & & $\mathrm{C} 2$ & & $\mathrm{~B} 1$ & 200,000 & $F$ & 25,000 \\
\hline $\mathrm{FB}-7$ & A3 & & $\mathrm{C} 2$ & & $\mathrm{~B} 2$ & & $F$ & 25,000 \\
\hline FB-8 & A3 & & A3 & & $\mathrm{B} 1$ & 200,000 & $\mathrm{~F}$ & 25,000 \\
\hline $\mathrm{FB}-9$ & A3 & & $\mathrm{A} 3$ & & B2 & & $F$ & 25,000 \\
\hline $\mathrm{L}-\mathrm{I}$ & B1 & & $\mathrm{Bl}$ & 70,000 & A2 & 100,000 & $\mathrm{~F}$ & 25,000 \\
\hline $\mathrm{L}-2$ & $\mathrm{~B} 1$ & & $\mathrm{~B} 1$ & 150,000 & A3 & & $\mathrm{F}$ & 25,000 \\
\hline $\mathrm{L}-3$ & $\mathrm{~A}^{2}$ & & $\mathrm{BI}$ & 320,000 & A2 & 550,000 & $\mathrm{~F}$ & 25,000 \\
\hline$L-4$ & B1 & & $\mathrm{D} 2$ & 320,000 & $\mathrm{C} 3$ & $1,000,000$ & $\mathrm{~F}$ & 25,000 \\
\hline$L-5$ & $A^{2} ?$ & & $\mathrm{~A} 2$ & 170,000 & A2 & 100,000 & $\mathrm{~A} 2, \mathrm{~B} 1$ & 25,000 \\
\hline$L-6$ & $A^{2} ?$ & & A2 & 170,000 & A2 & 125,000 & A2 & 16,000 \\
\hline$M L-I$ & A. 3 & & $\mathrm{Bl}$ & 50,000 & A2 & 100,000 & $\mathrm{Bl}$ & 1,000 \\
\hline $\mathrm{ML}-2$ & A3 & & $\mathrm{B} 1$ & 50,000 & $\mathrm{~A} 2$ & 100,000 & $\mathrm{~B} 1$ & 1,000 \\
\hline$M L-3$ & A3 & & $\mathrm{B} 1$ & 50,000 & A2 & 100,000 & B1 & 1,000 \\
\hline$M L-4$ & FL & & D2 & & B2 & 300,000 & $\mathrm{BI}$ & 6,000 \\
\hline$M L-5$ & FLL & & $\mathrm{E} 1$ & & B1 & 300,000 & $\mathrm{BI}$ & 6,000 \\
\hline$M L-6$ & $\mathrm{Fl}$ & & E2 & & $\mathrm{C} 3$ & $1,000,000$ & $\mathrm{~B} 1$ & 6,000 \\
\hline MH-1 & A3 & & A3 & & $\mathrm{A} 2$ & 13,000 & F1 & \\
\hline MH-2 & $A 2$ & & $\mathrm{D} 2$ & & $\mathrm{~A} 2$ & 125,000 & $\mathrm{BI}$ & 25,000 \\
\hline $\mathrm{MH}-3$ & $A ?$ & & A2 & 170,000 & A2 & 125,000 & A2 & 25,000 \\
\hline
\end{tabular}


Table E.4 (continuec)

\begin{tabular}{|c|c|c|c|c|c|c|c|c|}
\hline \multirow[b]{3}{*}{ Idencifier } & \multicolumn{8}{|c|}{ Manufacturer } \\
\hline & \multicolumn{2}{|c|}{ Delaval Turbine, Inc. } & \multicolumn{2}{|c|}{ Diebold, Inc. } & \multicolumn{2}{|c|}{ Dresser Clark } & \multicolumn{2}{|c|}{ Elliott Co. } \\
\hline & Availability & $\begin{array}{c}\text { Largest } \\
\text { capacity } \\
\text { (acf } m \text { ) }\end{array}$ & Avaizability & $\begin{array}{l}\text { Largest } \\
\text { capacity } \\
(\operatorname{acfm})\end{array}$ & Availability & $\begin{array}{l}\text { Largest } \\
\text { cadacity } \\
\text { (acfm) }\end{array}$ & Availability & $\begin{array}{l}\text { Largest } \\
\text { capacity } \\
\quad(\text { acfm })\end{array}$ \\
\hline FB-1 & A3 & & & & A3 & & A2 & 350,000 \\
\hline $\mathrm{FB}-2$ & A3 & & & & A3 & & $\mathrm{A} 2$ & 350,000 \\
\hline FB-3 & A3 & & & & A3 & & B1 & 350,000 \\
\hline FB-4 & $\mathrm{A}^{3}$ & & & & A3 & & A3 & 350,000 \\
\hline FB-5 & A3 & & & & A3 & & B2 & 350,000 \\
\hline $\mathrm{FB}-6$ & A3 & & & & A3 & & B1 & 350,000 \\
\hline $\mathrm{FB}-7$ & & & & & A3 & & B2 & 350,000 \\
\hline $\mathrm{FB}-8$ & A3 & & & & A3 & & B1 & 350,000 \\
\hline FB-9 & A3 & & & & A3 & & B2 & 350,000 \\
\hline $\mathrm{L}-\mathrm{I}$ & A2 & 541,000 & & & $\mathrm{~A} 2$ & 360,000 & $\mathrm{~A} 2$ & 280,000 \\
\hline $\mathrm{L}-2$ & $\mathrm{~A} 2$ & 541,000 & & & A3 & & $\mathrm{A} 2$ & 350,000 \\
\hline $\mathrm{L}-3$ & $\mathrm{~A} 2$ & 541,000 & & & A2 & 553,000 & $\mathrm{~A} 2$ & 350,000 \\
\hline $\mathrm{L}-4$ & $\mathrm{C4}$ & & & & $\mathrm{Cl}$ & & A3 & 350,000 \\
\hline $\mathrm{L}-5$ & A2 & 541,000 & & & $\mathrm{~A} 2$ & 360,000 & $\mathrm{~A} 2$ & 140,000 \\
\hline $\mathrm{L}-6$ & $\mathrm{~A} 2$ & 150,000 & & & $\mathrm{~A} 2$ & 151,000 & $\mathrm{~A} 2$ & 130,000 \\
\hline ML-1 & $\mathrm{A} 2$ & 150,000 & & & $\mathrm{~A} 2$ & 360,000 & $\mathrm{~A} 2$ & 110,000 \\
\hline$M L-2$ & A2 & 150,000 & & & $\mathrm{~A} 2$ & 360,000 & $\mathrm{~A} 2$ & 30,000 \\
\hline ML-3 & $\mathrm{A} 2$ & 150,000 & & & A2 & 360,000 & $\mathrm{~A} 2$ & 30,000 \\
\hline ML-4 & B2 & & & & $\mathrm{BI}$ & & $\mathrm{A} 2$ & 280,000 \\
\hline$M L-5$ & B2 & & & & $\mathrm{B} 1$ & & $\mathrm{~B} 1$ & 300,000 \\
\hline$M L-6$ & $\mathrm{C} 4$ & & & & E1 & & D2 & \\
\hline MH-1 & A3 & & & & $\mathrm{A} 3$ & & $\mathrm{~A} 3$ & \\
\hline MH-2 & B1 & 150,000 & & & B2 & & B1 & 140,000 \\
\hline MH-3 & $\mathrm{A} 2$ & 150,000 & & & $\mathrm{~A} 2$ & $15 c^{\circ}, 000$ & $\mathrm{~A} 2$ & 140,000 \\
\hline
\end{tabular}


Table E.4 (continued)

\begin{tabular}{|c|c|c|c|c|c|c|c|c|}
\hline \multirow[b]{3}{*}{ Identifier } & \multicolumn{8}{|c|}{ Manufacturer } \\
\hline & \multicolumn{2}{|c|}{ Gardner-Denver Co. } & \multicolumn{2}{|c|}{$\begin{array}{l}\text { Ingersoll Rand Co. } \\
\text { Turbo Products Division }\end{array}$} & \multicolumn{2}{|c|}{ Joy Manufacturing Co. } & \multicolumn{2}{|c|}{ Mechanical Equipment Co. } \\
\hline & Availability & $\begin{array}{l}\text { Largest } \\
\text { capacity } \\
\text { (acfm) }\end{array}$ & Availability & $\begin{array}{l}\text { Largest } \\
\text { capacity } \\
\quad(\text { acfm) }\end{array}$ & Availability & $\begin{array}{l}\text { Largest } \\
\text { capacity } \\
(\text { actm) }\end{array}$ & Availability & $\begin{array}{l}\text { Largest } \\
\text { capacity } \\
(\text { acfm) }\end{array}$ \\
\hline FB-1 & $\mathrm{A} 2$ & 6,000 & & & B2 & & B1 & \\
\hline $\mathrm{FB}-2$ & $\mathrm{~A} 2$ & 6,000 & & & B2 & & B1 & \\
\hline $\mathrm{FB}-3$ & $\mathrm{~A} 2$ & 6,000 & & & A3 & . & B1 & \\
\hline $\mathrm{FB}-4$ & A2 & 6,000 & & & A3 & & B1 & \\
\hline FB-5 & $\mathrm{A} 2$ & 6,000 & & & B2 & & $\mathrm{B} 1$ & \\
\hline $\mathrm{FB}-6$ & A2 & 6,000 & & & B2 & & $\mathrm{B} 1$ & \\
\hline FB-7 & Az̃. & 6,000 & & & B2 & & B1 & \\
\hline FB-8 & $\mathrm{A} 2$ & 6,000 & & & B2 & & $\mathrm{Bl}$ & \\
\hline FB-9 & $A \ddot{z}$ & 6,000 & & & B2 & & B1 & \\
\hline $\mathrm{L}-1$ & $A \ddot{i}$ & 3,000 & & & B2 & . & $\mathrm{B} 1$ & \\
\hline $\mathrm{L}-2$ & $\mathrm{~A} \hat{2}$ & 5,800 & & & A3 & 35,000 & $\mathrm{~B} 1$ & \\
\hline $\mathrm{L}-3$ & $A 2$ & 3,500 & & & A3 & 35,000 & B2 & \\
\hline $\mathrm{L}-4$ & $\mathrm{~A} 2$ & 3,500 & & & B2 & 35,000 & B2 & \\
\hline$L-5$ & $\mathrm{~A} 2$ & & & & B2 & & $\mathrm{B} 1$ & \\
\hline L-6 & $\mathrm{A}^{2}$ & 4,500 & & & A3 & & $\mathrm{BI}$ & \\
\hline ML-1 & $\mathrm{A}^{2}$ & 2,000 & & & B2 & & $\mathrm{A} 2$ & \\
\hline ML-2 & A2 & 2,000 & & & B2 & & $\mathrm{A} 2$ & \\
\hline ML-3 & A2 & 2,000 & & & B2 & & A3 & \\
\hline ML-4 & A2 & 3,000 & C3 & & $\mathrm{C} 2$ & & $\mathrm{BI}$ & \\
\hline ML-5 & A2 & 3,000 & 83 & & $\mathrm{C} 2$ & & $\mathrm{Bl}$ & \\
\hline ML-6 & $\mathrm{A} 2$ & $3,00 \mathrm{C}$ & $\mathrm{C} 3$ & & $\mathrm{C} 2$ & & B1 & \\
\hline MH-1 & $A \geq$ & $2,00 \mathrm{C}$ & & & B2 & & & \\
\hline MH-2 & $A \geq$ & $2,00 C$ & $\mathrm{C} 3$ & & A3 & & & \\
\hline MH-3 & $\mathrm{A} 2$ & $3,00 C$ & & & A3 & & & \\
\hline
\end{tabular}


Table E.4 (continued)

\begin{tabular}{|c|c|c|c|c|c|c|c|c|}
\hline \multirow[b]{3}{*}{ Idertifier } & \multicolumn{8}{|c|}{ Manufacturer } \\
\hline & \multicolumn{2}{|c|}{ Rotoflow Corp. } & \multicolumn{2}{|c|}{ The Spencer Turbine Co. } & \multicolumn{2}{|c|}{ Sulzer Brothers, Ine. } & Turbonetics, & Inc. \\
\hline & Availability & $\begin{array}{l}\text { Largest } \\
\text { capacity } \\
(\operatorname{acf})\end{array}$ & Availability & $\begin{array}{l}\text { Largest } \\
\text { capacity } \\
(\text { acfm })\end{array}$ & Availabili:-y & $\begin{array}{l}\text { Jargest } \\
\text { capacity } \\
(\operatorname{acfm})\end{array}$ & Availability & $\begin{array}{l}\text { Largest } \\
\text { capacity } \\
(\text { acfm })\end{array}$ \\
\hline $\mathrm{FB}-1$ & & & A2 & 25,000 & & & A3 & \\
\hline $\mathrm{FB}-2$ & & & $\mathrm{~A} 2$ & 20,000 & . & & A3 & \\
\hline $\mathrm{FB}-3$ & & & A2 & 25,000 & & & A3 & \\
\hline $\mathrm{FB}-4$ & & & A2 & 25,000 & & & A3 & \\
\hline $\mathrm{FB}-5$ & $\cdot$ & 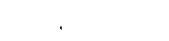 & $\mathrm{A} 2$ & 25,000 & & & A3 & \\
\hline $\mathrm{FB}-6$ & & & A2 & 10,000 & & & A3 & \\
\hline $\mathrm{FB}-7$ & & & A2 & 10,000 & & & A3 & - \\
\hline $\mathrm{FB}-8$ & & & $\mathrm{~A} 2$ & 20,000 & & & A3 & \\
\hline FB-9 & & & $\mathrm{A} 2$ & 20,000 & & & A3 & \\
\hline $\mathrm{L}-1$ & $\mathrm{~A} 2$ & 114,000 & A3 & & Aẑ́. & $2 ; 0,000$ & A3 & \\
\hline $\mathrm{L}-2$ & $\mathrm{~A} 2$ & 110,000 & A2 & 25,000 & $\hat{A} \hat{z}$ & $540,0 \mathrm{C} 0$ & A3 & \\
\hline$L-3$ & $\mathrm{~A} 2$ & 175,000 & $\mathrm{~A} 3$ & & A] & $2 \in 0,000$ & A3 & \\
\hline $\mathrm{L}-4$ & $\mathrm{~A} 2$ & 455,000 & A3 & & $\mathrm{A} \hat{2}$ & 260,000 & & \\
\hline $\mathrm{L}-5$ & $\mathrm{~A} 2$ & 75,000 & $\mathrm{~A} 2$ & 10,000 & $A \tilde{z}$ & 120,000 & A3 & \\
\hline$L-6$ & $\mathrm{~A} 2$ & 10,000 & A3 & & $\mathrm{AZ}$ & $9.5,000$ & & \\
\hline$M L-1$ & $\mathrm{~A} 2$ & 82,00 & A3 & & $\mathrm{B} 1$ & 120,000 & A3 & \\
\hline M-2 & $\mathrm{A} 2$ & 11,000 & A3 & & $A 2$ & 120,000 & A2 & 30,000 \\
\hline$M L-3$ & A2 & 20,000 & A3 & & B1 & 120,000 & $\mathrm{Bl}$ & 30,000 \\
\hline ML-4 & $\mathrm{A} 2$ & 150,000 & A3 & $\cdot$ & $\mathrm{A} 2$ & 65,000 & A3 & \\
\hline$M L-5$ & A2 & 150,000 & 43 & & A2 & 65,000 & & \\
\hline ML-6 & A2 & 150,000 & $A^{3}$ & & $\mathrm{~A} 2$ & 65,000 & & \\
\hline MH-1 & $\mathrm{A} 2$ & 150,000 & A3 & . & & & A3 & \\
\hline MI:-2 & A2 & 35,000 & A3 & & B1 & & A3 & \\
\hline $\mathrm{MH}-3$ & A2 & 16,000 & A3 & & A2 & 65,000 & A3 & \\
\hline
\end{tabular}


Table E.4 (continued)

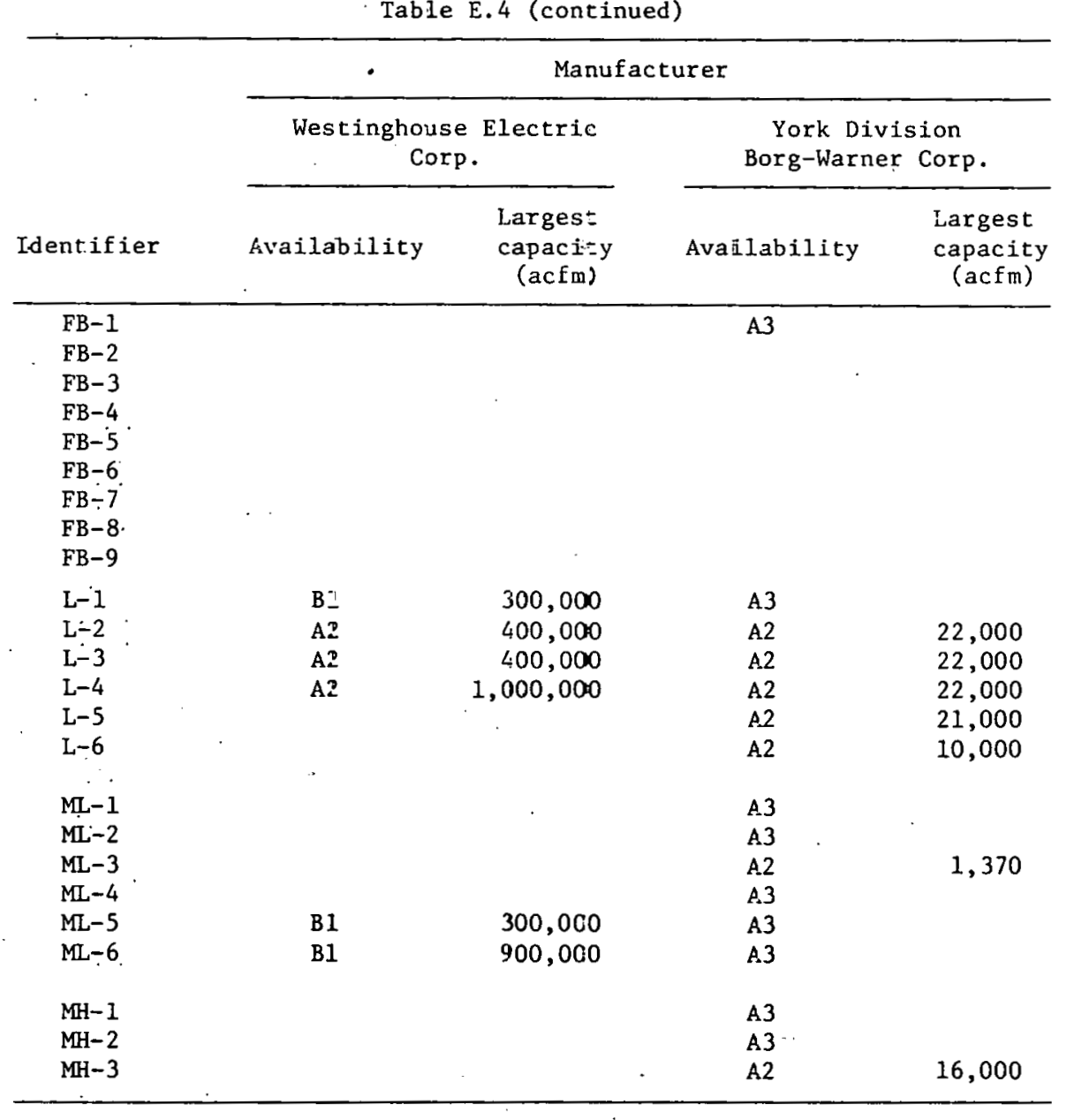


Table E.5. Responses from marufacturers to questions on availability and capacity

Compressors: HL, HH, and VH series

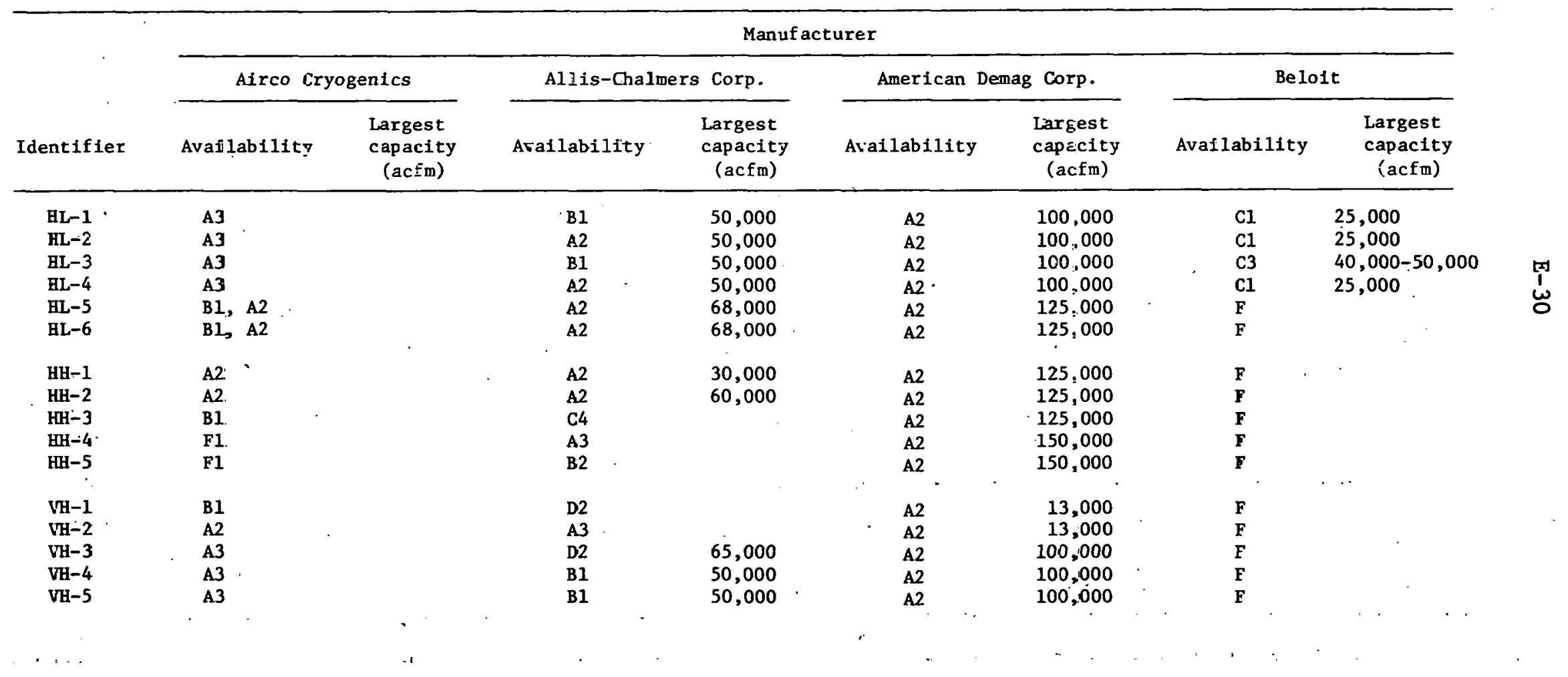


Table E. 5 (continued)

\begin{tabular}{|c|c|c|c|c|c|c|c|c|}
\hline \multirow{3}{*}{ Identifier } & \multicolumn{8}{|c|}{ Manufacturer } \\
\hline & \multicolumn{2}{|c|}{ Eelaval Turbine, Inc. } & \multicolumn{2}{|c|}{ Diebold, Inc. } & \multicolumn{2}{|c|}{ Dresser Clark } & \multicolumn{2}{|c|}{ Elliott Co. } \\
\hline & Availability & $\begin{array}{c}\text { Largest } \\
\text { capacity } \\
(\operatorname{acfm})\end{array}$ & Availability & $\begin{array}{l}\text { Largest } \\
\text { capacity } \\
\text { (acfm) }\end{array}$ & Availability & $\begin{array}{l}\text { Largest } \\
\text { capacity } \\
(\text { acfm) }\end{array}$ & Availability & $\begin{array}{l}\text { Largest } \\
\text { capacity } \\
\text { (acfm) }\end{array}$ \\
\hline $\mathrm{HL}-1$ & A2 & 30,000 & & & A2 & 66,000 & A2 & 55,000 \\
\hline $\mathrm{HL}-2$ & $\mathbf{\Delta} 2$ & 30,000 & & & A2 & 66,000 & A2 & 55,000 \\
\hline $\mathrm{HL}-3$ & A2 & 60,000 & & . & A2 & 66,000 & A2 & 55,000 \\
\hline $\mathrm{HL}-4$ & A2 & 30,000 & & & A2 & 66,000 & A2 & 55,000 \\
\hline HL-5 & $\mathrm{B} 2, \mathrm{~h} 2$ & 150,000 & & & A2 & 66,000 & A2 & 55,000 \\
\hline $\mathrm{HL}-6$ & A2 & 150,000 & & . & A2 & 66,000 & A2 & 55,000 \\
\hline $\mathrm{HH}^{\prime}-1$ & A2 & 150,000 & & & A2 & 180,000 & A2 & 55.000 \\
\hline 'HH-2 & A2 & 150,000 & & & $\mathbf{A} 2$ & 180,000 & A2 & 55,000 \\
\hline $\mathrm{HH}-3$ & A2 & 150,000 & & & A2 & 180,000 & A2 & 55,000 \\
\hline $\mathrm{HH}-4$ & B1 & 150,000 & & & A2 & 45,000 & A2 & 55,000 \\
\hline $\mathrm{HH}-5$ & BI & 150,000 & & & A3 & 45,000 & A2 & 75,000 \\
\hline $\mathrm{VH}-1$ & B2 & & & & A2 & & A2 & 11,000 \\
\hline $\mathrm{VH}-2$ & B2 & & & - & A2 & & A3 & \\
\hline Vit-3 & B2 & & & & C2 & & $\mathrm{C} 2$ & $\therefore$ \\
\hline VH-4 & B2 & & & · & A2 & 14,000 & B1 & \\
\hline .. VH-5 & B2 & & & . & B1 & & $\mathrm{C} 2$ & \\
\hline
\end{tabular}


Table E.5 (continued)

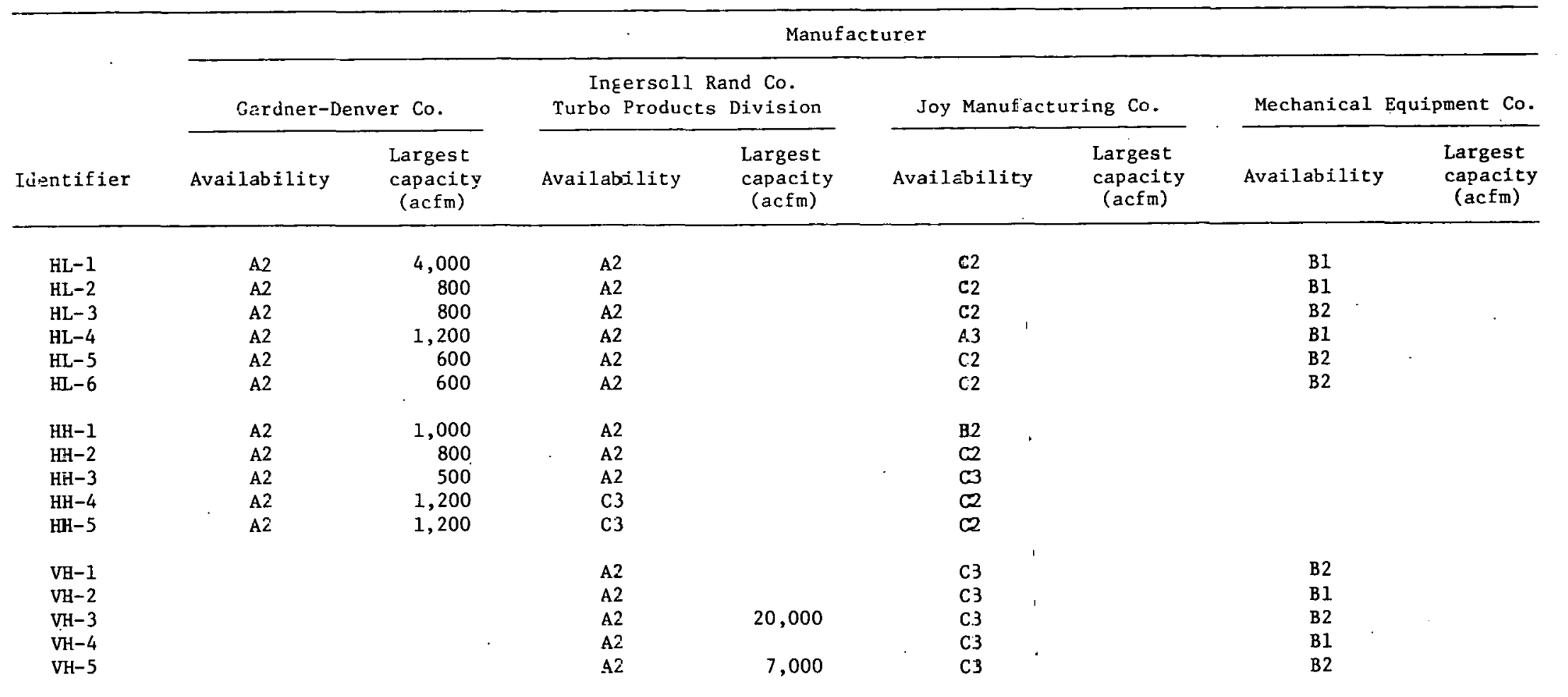


Table E.5 (continued)

\begin{tabular}{|c|c|c|c|c|c|c|c|c|c|}
\hline \multirow[b]{3}{*}{ Zdentifier } & \multicolumn{9}{|c|}{ Manufacturer } \\
\hline & \multicolumn{2}{|c|}{ Rot of low Corp. } & \multicolumn{3}{|c|}{ The Spencer Turbine Co. } & \multicolumn{2}{|c|}{ Sulzer Brothers, İnc. } & \multicolumn{2}{|c|}{ Turbonetrics, Inc. } \\
\hline & Availability & $\begin{array}{l}\text { Largest } \\
\text { capacity } \\
(\text { acfm) }\end{array}$ & & Availability & $\begin{array}{c}\text { Largest } \\
\text { capacity } \\
(\text { acfm })\end{array}$ & Availability & $\begin{array}{l}\text { Largest } \\
\text { capacity } \\
\text { (acfm) }\end{array}$ & Availability & $\begin{array}{l}\text { Largest } \\
\text { capacity } \\
(\text { acfm) }\end{array}$ \\
\hline $\mathrm{HL}-1$ & & & & 43 & & $\mathrm{~A} 2$ & 56,000 & B1 & 10,500 \\
\hline $\mathrm{HL}-2$ & . & & & A3 & $\cdot$ & $\mathrm{A} 2$ & 100,000 & B1 & 30,000 \\
\hline HL-3 & 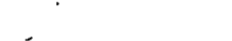 & & & A3 & & $\mathrm{B} 1$ & 100,000 & - A3 & \\
\hline HL-4 & & & & A3 & & A2 & 85,000 & $\mathrm{~B} 1$ & 10,500 \\
\hline $\mathrm{HL}-5$ & & & & A3 & & $\mathrm{A} 2$ & 120,000 & B1 & 10,500 \\
\hline $\mathrm{HL}-6$ & & . & & A3 & & $\mathrm{A} 2$ & 120,000 & B1 & 10,500 \\
\hline $\mathrm{HH}-1$ & A 2 & $25,00 G_{i}$ & & A3 & & A2 & 120,000 & A3 & \\
\hline $\mathrm{HH}-2$ & $\mathrm{~A} 2$ & & & A3 & & $\mathrm{A} 2$ & 120,000 & A3 & \\
\hline $\mathrm{HH}-3$ & $A 2$ & 30,000 & & A3 & & $\mathrm{A} 2$ & 120,000 & A3 & \\
\hline $\mathrm{HH}-4$ & $\mathrm{~A} 2$ & 35,000 & - & A3 & & $\mathrm{A} 2$ & 60,000 & A3 & \\
\hline $\mathrm{HH}-5$ & $\mathrm{~A} 2$ & 70,000 & & A3 & & $\mathrm{A} 2$ & 60,000 & A3 & \\
\hline vH-1 & & & & A3 & & s $>$ & & & \\
\hline $\mathrm{VH}-2$ & & 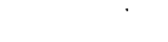 & & A3 & & . & & & \\
\hline $\mathrm{VH}-3$ & A2 & 40,000 & & A3 & . & $\mathrm{Bl}$ & 45,000 & . & \\
\hline $\mathrm{VH}-4$ & $A 2$ & 7,000 & & A3 & & $\mathrm{A} 2$ & 55,000 & & \\
\hline $\mathrm{VH}-5$ & $A 2$ & 28,000 & & A3 & & $\mathrm{Bl}$ & 55,000 & & \\
\hline
\end{tabular}


Table E.5 (continued)

\begin{tabular}{|c|c|c|c|c|}
\hline \multirow[b]{3}{*}{ Identifier } & \multicolumn{4}{|c|}{ Manufacturer } \\
\hline & \multicolumn{2}{|c|}{$\begin{array}{l}\text { Westinghouse Electric } \\
\text { Corp. }\end{array}$} & \multicolumn{2}{|c|}{$\begin{array}{c}\text { York Division } \\
\text { Bcrg-Warner Corp. }\end{array}$} \\
\hline & Availability & $\begin{array}{l}\text { Largest } \\
\text { capacity } \\
\text { (acfm) }\end{array}$ & Availability & $\begin{array}{l}\text { Largest } \\
\text { capacity } \\
(\text { acfm })\end{array}$ \\
\hline HL-1 & & & A2 & 1,200 \\
\hline $\mathrm{HL}-2$ & & & A.2 & 2,000 \\
\hline $\mathrm{HL}-3$ & & & A2 & 2,100 \\
\hline $\mathrm{HL}-4$ & & & A2 & 1,800 \\
\hline HL-5 & & & A2 & 2,300 \\
\hline $\mathrm{HL}-6$ & & & A2 & 2,300 \\
\hline $\mathrm{HH}-1$ & & & A3 & \\
\hline $\mathrm{HH}-2$ & & & A2 & 15,000 \\
\hline $\mathrm{HH}-3$ & & & $\mathrm{~A}^{3}$ & \\
\hline , $\mathrm{HH}-4$ & & & $A 3$ & \\
\hline $\mathrm{HH}-5$ & & & $\mathrm{~A} 3$ & \\
\hline VH-1 & & & A3 & \\
\hline $\mathrm{VH}-2$ & - & & & \\
\hline VH-3 & & & A3 & \\
\hline $\mathrm{VH}-4$ & & & A3 & \\
\hline $\mathrm{VH}-5$ & & & & \\
\hline
\end{tabular}


Table E.6. Responses from manufacturers to questions on availability and capacity

Hydraulic turbines

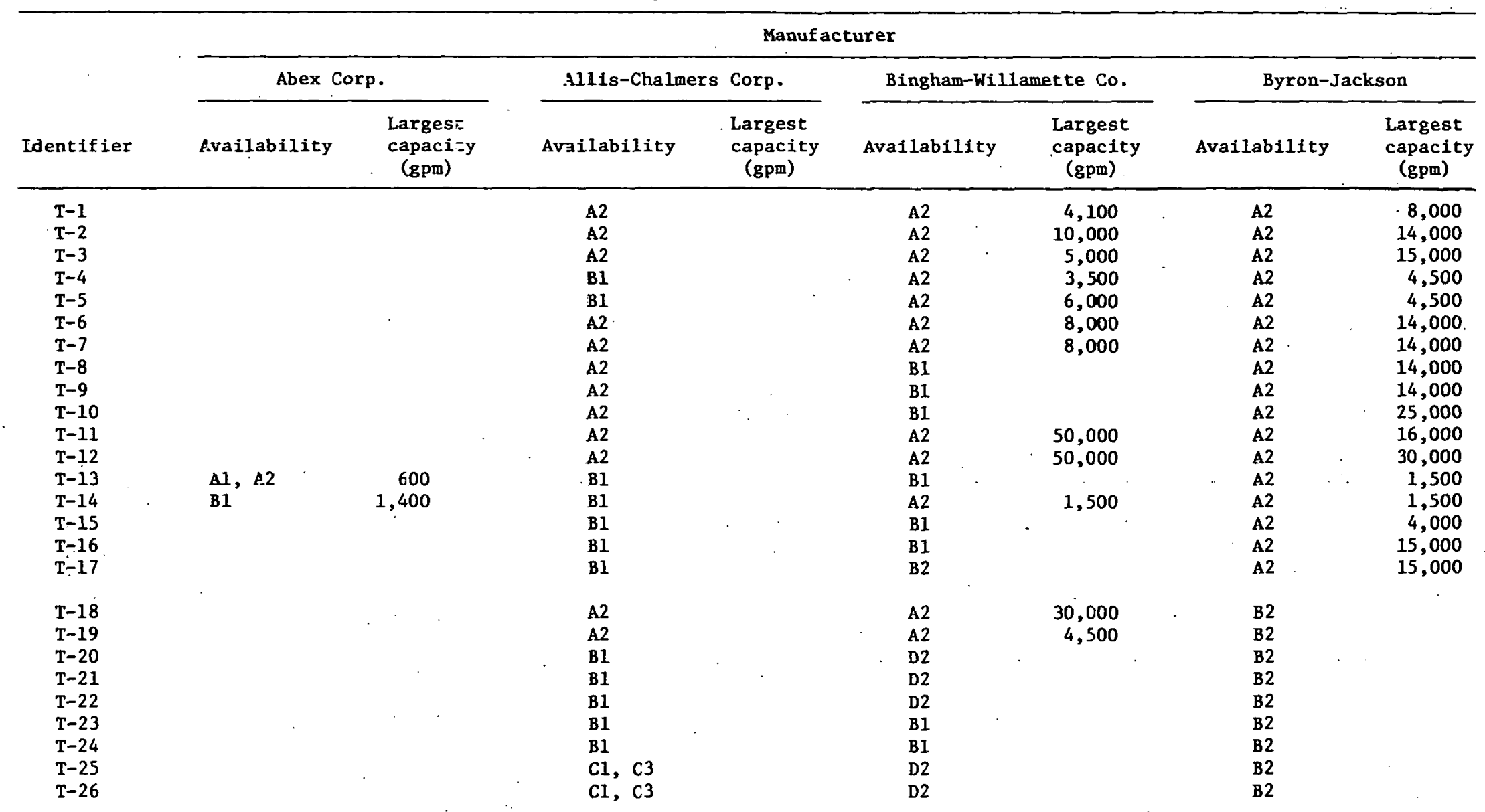


Table E.6 (continued)

\begin{tabular}{|c|c|c|}
\hline \multirow[b]{3}{*}{ Identifier } & \multicolumn{2}{|c|}{ Manufacturer } \\
\hline & \multicolumn{2}{|c|}{ Dresser Industries } \\
\hline & Availability & $\begin{array}{l}\text { Largest } \\
\text { capacity } \\
\text { (gpm) }\end{array}$ \\
\hline $\mathrm{T}-1$ & $\mathrm{~A} 2$ & 700 \\
\hline $\mathrm{T}-2$ & A2 & 20,000 \\
\hline$T-3$ & $\mathrm{~A} 2$ & 40,000 \\
\hline$T-4$ & $\mathrm{~A} 2$ & 50,000 \\
\hline$T-5$ & A2 & 50,000 \\
\hline$T-6$ & $\mathrm{~A} 2$ & 50,000 \\
\hline $\mathrm{T}-7$ & A2. & 90,000 \\
\hline$T-8$ & A2 & 90,000 \\
\hline$T-9$ & A2 & 20,000 \\
\hline $\mathrm{T}-10$ & A2 & 40,000 \\
\hline $\mathrm{T}-11$ & A2 & 40,000 \\
\hline $\mathrm{T}-12$ & A2 & 40,000 \\
\hline $\mathrm{T}-13$ & A2 & 50,000 \\
\hline $\mathrm{T}-14$ & A2 & 50,000 \\
\hline $\mathrm{T}-15$ & A2 & 50,000 \\
\hline$T-16$ & A2 & 50,000 \\
\hline$T-17$ & $\mathrm{~A} 2$ & 50,000 \\
\hline $\mathrm{T}-18$ & B1 & 40,000 \\
\hline $\mathrm{T}-19$ & A2 & 20,000 \\
\hline $\mathrm{T}-20$ & $\mathrm{~A} 2$ & 20,000 \\
\hline $\mathrm{T}-21$ & $\mathrm{~A} 2$ & 20,000 \\
\hline $\mathrm{T}-22$ & $\mathrm{~A} 2$ & 20,000 \\
\hline $\mathrm{T}-23$ & A2 & 40,000 \\
\hline$T-24$ & $\mathrm{~A} 2{ }^{\circ}$ & 40,000 \\
\hline $\mathrm{T}-25$ & B1 & 9,000 \\
\hline$T-26$ & B1 & 9,000 \\
\hline
\end{tabular}


INTERNAL DISTRIBUTION

1. T. D. Anderson

2. T. M. Andress

3. W. J. Armento

4. H. C. Beeson

5. M. Bender

6-7. W. F. Boudreau

8. W. A. Bush

9. D. D. Cannon

10. C. J. Claffey

11. H. D. Cochran

12. B. F. Crump

13. M. H. Culver

14. T. E. Douglas

15. I. T. Dudley

16. M. S. Edwards

17. J. F. Fisher

18. J. Foster

19. J. T. Fowler

20. W. R. Gambill

21. R. W. Glass

22. A. Grindel1

23. B. H. Hale

24. H. F. Hartman

25. D. W. Hatcher

26. R. M. Hill

27. A. Hobison

28. J. M. Holmes

29-68. J. R. Horton

69. J. K. Huffstetler

70. G. R. Jasny

71. J. E. Jonca, Jr .

72. J. R. Joplin

73. D. R. Kellogg

74. R. T. King

75. J. J. Kurtz

76. R. E. Lampton

77. C. C. Littlefield

78. R. E. MacPherson

79-82. L. E. McNeese
83-87. J. R. McWherter

88. J. P. Meyer

89. R. P. Milford

90. J. T. Milloway, III

91. I. K. Namba

92. J. P. Nichols

93. B. Niemann

94. H. H. Osborne

95. J. A. Parsons

96. F. S. Patton

97. T. W. Pickel

98. W. Pokela

99. W. R. Reed

100. G. W. Renfro

101. M. W. Rosentha1

102. R. Salmon

103. C. D. Scott

104. T. Shapiro

105-106. M. Siman-Tov

107. S. P. N. Singh

108. E. C. Slade

109. C. B. Smith

110. L. H. Stinton

111. B. T. Thompson

112. C. B. Tolliver

113. W. C. Ulrich

1.1.4. J. E, Vasgaard

115. H. C. Webb

116. L. A. Weeren

117-121. W. R. Williams

122. I.. V. Wilson

123. F. C. Zapp

124-125. Central Research Library Document Reference Section

126-127. Laboratory Records Department

128. Laboratory Records (RC)

129. ORNL Patent Office

130-132. Technical Publications 
EXTERNAL DISTRIBUTION

133. R. Antonsen, Department of Energy, Washington, DC 20545

134. Ron J. Archer, Lamson Division, Diebold, Inc., 685 Lamson St., Syracuse, NY 13201

135. Waldemar Arndt, Lawrence Pumps, Inc., 371 Market St., Lawrence, MA 01843

136. Warren S. Askew, Gilbert Associates, 1828 L St., NW, Washington, DC 20036

"137. T. Atwood, Department of Energy, Washington, DC 20545

138. William B. Bailey, Turbo Compressor Division, The Spencer. Turbine Company, 600 Day Hill Road, Windsor, CT 06095

139. Wate T. Bakker, Department of Energy, Washington, DC 20545

140. J. Batchelor, Department of Energy, Washington; DC 20545

141. W. A. Beekman, Peabody Floway, Inc., P.O. Box 164, Fresno, CA 93707

142. John Beveri,ge, Airco Cryogenics, 1900 Main St.,. Irvine, CA 92716

143. John C. Bixel, Monsanto Research Corp., Muund Facility, P.O. Box 5555, Miamisburg, OH 45342

144. George Bohensky, Machinery Services Division, Exxon Research \& Engineering Cullpany, P.U. Box 1U1, Florham Park, MD 07932

145. John Borin, Rotoflow Corporation, 2235 Carmelina Ave., Los Angeles, CA 90064

146. Thomas T. Brown, Dresser Industries, Inc., Dresser Clark Division, P.0. Box 560, Olean, NY 14760

147. George Campbell, Worthington (Canada) Ltd., P.0. Box 40, Brantford, Ontario N3T 5M5, Canada

148. G. W. Carpender, Stearns-Roger, P.0. Box 5888, Denver, C0 80217

149. M. A. Christensen, Department of Energy, Washingtnn, Dr. $205 \% 5$

130. Ł. L. Clark, Department of Energy, Washington, DC 20545

151. Ford Clayton, Kingston Power Plant, Tennessee Valley Authority, Kingston, TN 37763

152. Michele Cole, Liaison and Information Services, University of Pittsburgh, 3500 Victoria St., Pittsburgh, PA 15261

153. Olin Colitti, Department of Energy, Washington, DC 20545

154. James E. Davee, Roper Pump Company, P.0. Box 269, Commerce, GA 30529

155. Donald J. Demoy, Warren Pumps, Inc., Subsidiary of Houdaille Industries, Inc., Warren, MA 01083

156. W. B. Devoe, Delaval Turbine, P.O. Box 251, Trenton, NJ 08642

157. Albert Dolbec, . EPRI, 3412 Hillview Ave., Palo Alto, CA 94304

158. Ray Dugal, R. M. Parsons Company, 100 West Walnut, Pasadena, CA 91124

159. John M. Duncan, Shel1 Development Co., P.O. Box 2463, Houston, TX 77001

160. Douglas R. Eaton, Intertechnology Corp., P.0. Box 340, Warrenton, VA 22186

161. J. B. Feinstein, United Centrifugal Pumps, 1132 North Seventh St., San Jose, CA 95112 
162. Henry H. Flock, Chicago Division, Tuthill Pump Company, $12500 \mathrm{~S}$. Crawhord Ave., Chicago, IL 60658

163. J. J. Forst, Department of Energy, Washington, DC 20545

164. H. E. Frankel, Department of Energy, Washington, DC 20545

165. J. Fullam, Turbo Products Division, Ingersoll-Rand Company, 942 Memorial Parkway, Phillipsburg, NJ 08865

166. D. Garrett, Department of Energy, Washington, DC 20545

167. Ray Glasscock, Charter Oil Company, P.0. Box 5008, Houston, TX 77012

168. L. R. Greenhaus, Joy Manufacturing Company, Montgomeryville Industrial Center, Montgomeryville, PA 18936

169. W. D. Haentjens, Barrett, Haentjens \& Company, P.0. Box 488, Hazleton, PA 18201

170. D. B. Harney, Pacific Pumps Division, Dresser Industries, Inc., 571.5 Bickett St., Huntington Park, CA 90255

171. John Holm, Rotoflow Corporation, 2235 Carmelina Ave., Los Angeles, CA 90064

172. J. H. Howard, Industrial Machinery Division, Gardner-Denver Company, 1800 Gardner Expressway, Quincy, IL 62301

173. Terry Hoye, Terry Steam Turbine Company, Lamberton Road, Windsor, CT 06095

174. John Hugele, Elliott Company, Division of Carrier Corp., North Fourth St., Jeannette, PA 15644

175. W. B. Ingram, Tang Industries, Beloit Power Systems, Inc., 555 Lawton Ave., Beloit, WI 53511

176. Hershul T. Jones, Department of Energy, Washington, DC 20545

177. Tony Katsantoness, Fairbanks Morse Pump Division, Colt Industries Operating Corp., 3601 Kansas Ave., Kansas City, KS 66110

178. John Kirkland, Tennessee Valley Authority, 400 Commerce Ave., Knoxville, TN 37902

179. D. B. Kiser, Delạal Turbine, P.O. Box 251, Trenton, NJ 08642

180. H. R. Klein, Byron Jackson Pump Division, Borg-Warner Corporation, P.0. Box 2017 Terminal Annex, Los Angeles, CA 90051

181. Robert F. Kohanski, Dresser Clark Division, Dresser Industries, Tnr., P.n. Rox 560, Olean, NY 14760

182-221. T. K. Lau, Department of Energy, Washington, DC 20545

222. Arthur G. Leach, Labour Pump Company, P.0. Box 1187, E1khart, IN 46514

223. Felix B. Leeton, Compressor Division, Allis Chalmers Corp., 440 N. Foster Drive, Suite 119, Baton Rouge, LA 70806

224. J. A. Lenhard, Department of Energy, Oak Ridge, TN 37830

225. V. H. Tucke, General Electric Company, 1 River Road, Schenectady, NY 12345

226. D. M. Luintz, Department of Energy, Washington, DC 20545

227. J. Mahan, Cameron Pump Division, Ingersoll-Rand Company, P.0. Box 486, Phillipsburg, NJ 08865

228. Market Manager, IMO Pump Division, Delaval Turbine, Inc., P.0. Box 321, Trenton, NJ 08602

229. R. Martino, Engine Process Compressor Division, Ingersoll-Rand Company, Painted Post, NY 14870 
230. Richard Z. Mason, William Brothers Process Services, Inc., Resource Science Center, 6600 S. Yale Ave., Tulsa; OK 74136

231. Howard A. Mayo, Jr., Hydro-Turbine Division, Allis-Chalmers Corporation, P.0. Box 712, York, PA 17405

232. R. L. McCafferty, Gulf Science \& Technology Company, P.O. Drawer 2038, Pittsburgh, PA 15230

233. J. A. McCollum, National Fertilizer Development Center, Tennessee Valley Authority, Muscle Shoals, AL 35660

234. J. T. Milloway, Jr., Department of Energy, Oak Ridge, TN 37830

235. Charles A. Mirenda, Proposal Management, Inc., 121 North ... Cerianna St., Philadelphia, PA 19106

236. John A. Moore, The Oil Daily, 827 National Press Building, Washington, DC 20045

237. J. A. Morse, Galigher Company, Baker International, 440 West 8 th South, Salt Lake Ci.ty, UT 84110

238. Art Murphy, Jet Propulsion Laboratory, Pasadena, CA 91.1.09

239. T. J. Nakley, Department of Energy, Washington, DC 20545

240. R. E. Nelson, Blackmer Pump Division, Dover Corporation, 1809 Century, Grand Rapids, MI 49506

241. Richard M. Nelson, Bingham-Willamette Company, 2800 NW Front Ave., Portland, OR 97210

242. M. Neuworth, Department of Energy, Washington, DC 20545

243. J. B. O'Hara, R. M. Parsons Company, 100 West Walnut, Pasadena, CA 91124

244. D. J. O'Rourke, Denison Division, Abex Corporation, 1160 Dublin Road, Columbus, $\mathrm{OH} 43216$

245. W. H. Owen, Delaval, P.0. Box 2072, Princeton, NJ 08540

246. J. G. Patel, Institute of Gas Technology, 3424 S. State St., Chicago, IL 60616

247. R. E. Payne, Exxon Oil Company, P.0. Box 3950, Baytown, TX 77500

248. Robert Phen, Jet Propulsion Laburatory, Pasadena, CA 91109

249. F. N. Piasecki, Piasecki Aircraft Corp., Island Ave., International Airport, Philadelphia, PA 19153

250. William Pietrucha, Coal Industry News, 20 Community Place, Morristown, NJ 07960

251. H. P. Pletscher, Sulzer Brothers, Inc., 19 Rector St., New York, NY 10006

252. John Popek, Turbine Division, Delaval Turbine, Inc., P.O. Box 251, Trenton, NJ 08602

253. John Pottharst, III, Mechanical Equipment Company, Inc., 861 Carondelet St., Ncw Orleans, J.A 70130

254. James L. Powe11, Department of Energy, Washington, DC 20545

255. L. L. Radcliffe, Department of Energy, Oak Ridge, TN 37830

256. P. B. Ricci, Delaval Turbine, Inc., 3379 Peachtree Road, NE, Atlanta, GA. 30326

257. G. S. Rosenberg, Argonne National Laboratory, Argonne, IL 60439

258. J. C. Rybak, Wiḷson-Snyder Pumps, United States Steel Corporation, 2001 North Lamar St., Box 478, Dallas, TX 75221

259. Ben R. Scarbrough, Marine Marketing Division, Westinghouse Electric Corporation, Hendy Ave., Sunnyvale, CA 94088 
260. John W. Schlirf, Elliott Company, Jeannette, PA 15644

261. C. R. Schweizer, Sulzer Brothers, Inc., 19 Rector St., New York, NY 10006

262. P. R. Scordo, Centrifugal Compressor Division, Delaval Turbine Inc., P.0. Box 251, Trenton, NJ 08602

263. J. D. Shaver, National Supply Company, Division of Armco Steep Corp., 1455 W. Loop South, Houston, TX 77027

264. T. B. Simpson, Department of Energy, Washington, DC 20545

265. Jack Smith, Department of Energy, Washington, DC 20545

266. Merl Smith, Turbonetics, Inc., 968 Albany-Shaker Road, Latham, NY 12110

267. Thomas Speidel, Energy Systems, Thermo-Electron Corp., 101 First Ave., Waltham, MA 02154

268. Erhard R. Stallman, Compression Equipment Division, American Demag Corporation, 450 Park Ave., New York, NY 10022

269. D. B. Stone, Central Division, The Duriron Company, Inc., 425 N. Findlay St., Dayton, OH 45401

270. A. H. Strom, Department of Energy, Washington, DC 20545

271. James B. Studebaker, A. R. Wilfley \& Sons, Inc., P.0. Box 2330 , Denver, CO 80201

272. Willis E. Sullivan, The Garrett Corp., 1625 Eye St., NW, Washington, DC 20006

273. Joseph T. Swartzbaugh, Systems Technology Corp., 245 North Valley Road, Xenia, OH 45385

274. F. F. Szczesny, Compressor Division, Allis-Chalmers Corp., P.0. Box 512, Milwaukee, WI 53201

275. J. C. Taliaferro, Morris Pumps, Inc., 31 E. Genesee St., Baldwinsville, NY 13027

276. J. B. Thomas, Standard Pump-Aldrich Division, Ingersoll-Rand Company, Allentown, PA 18105

277. Willtam E. Thompson, Turbo Research, Inc., 212 Welsh Pool Road, Lionsville, PA 19353

278. Leon B. Timmerman, Pump Division, Buffalo Forge Company, P.0. Box 985 , Buffalo, NY 14240

279. E. B. Trescott, Department of Energy, Washington, DC 20545

280. R. A. Verner, Department of Energy, Washington, DC 20545

281. E. T. Voss, Chemicals and Plastics Division, Union Carbide Corporation, Hawnville, AL 70057

282. T. S. Wan, York Division, Borg-Warner Corp., P.0. Box 1592, York, PA 17405

283. H. Weisenfeld, Department of Energy, Washington, DC 20545

284. W. Wolentarsky, Linde Division, Union Carbide Corporation, P.O. Box 44, Tonawanda, NY 14150

285. R. A. Worthen, Ingersol1-Rand Research, Inc., P.0. Box 301, Princeton, NJ 08540

286. W. F. Young, Turbine Division, Delaval Turbine, Inc.', P.0. Box 251, Trenton; NJ 08602

287. James J. Zimmerman, Kinetics Corp., 46 Wooderest Drive, Scotia, NY 12302

288. Mike Zoborowski, Zimpro, Inc., Military Road, Rothschild, WI 54474

289-315. Technical Information Center, DOE-ORO. 